UNIVERSIDADE DE SÃO PAULO

INSTITUTO DE PSICOLOGIA

CURSO DE PÓS-GRADUAÇÃO - PROGRAMA DE PSICOLOGIA CLÍNICA

MARCELO SOARES DA CRUZ

ADICÇÃO AO OUTRO EM PACIENTES FRONTEIRIÇOS:

UM ESTUDO PSICANALÍTICO

São Paulo

2016 
UNIVERSIDADE DE SÃO PAULO

INSTITUTO DE PSICOLOGIA

CURSO DE PÓS-GRADUAÇÃO - PROGRAMA DE PSICOLOGIA CLÍNICA

MARCELO SOARES DA CRUZ

ADICÇÃO AO OUTRO EM PACIENTES FRONTEIRIÇOS:

UM ESTUDO PSICANALÍTICO

Tese apresentada ao Instituto de Psicologia da Universidade de São Paulo para obtenção do título de doutor em Psicologia

Área de Concentração: Psicologia Clínica

Orientadora: Profa. Dra.

Leila Salomão de La Plata Cury Tardivo

São Paulo

2016 
AUTORIZO A REPRODUÇÃO E DIVULGAÇÃO TOTAL OU PARCIAL DESTE TRABALHO, POR QUALQUER MEIO CONVENCIONAL OU ELETRÔNICO, PARA FINS DE ESTUDO E PESQUISA, DESDE QUE CITADA A FONTE.

Catalogação na publicação

Biblioteca Dante Moreira Leite

Instituto de Psicologia da Universidade de São Paulo

Cruz, Marcelo Soares da.

Adição ao outro em pacientes fronteiriços: Um estudo psicanalítico / Marcelo Soares da Cruz; orientadora Leila Salomão de La Plata Cury Tardivo. - São Paulo, 2016.

$262 \mathrm{f}$.

Tese (Doutorado - Programa de Pós-Graduação em Psicologia. Área de Concentração: Psicologia Clínica) - Instituto de Psicologia da Universidade de São Paulo.

1. Psicanálise 2. Psicopatologia 3. Borderline 4. Estados-limite 5. Adicção I. Título.

RC504 
CRUZ, Marcelo Soares da. Adição ao outro em pacientes fronteiriços: Um estudo psicanalítico. Tese apresentada ao Instituto de Psicologia da Universidade de São Paulo para obtenção do título de doutor em Psicologia.

Aprovado em:

Banca Examinadora

Profa. Dra. Leila Salomão de La Plata Cury Tardivo (orientadora)

Instituição: Instituto de Psicologia da Universidade de São Paulo

Julgamento:

Assinatura:

Profa. Dra. Laura Carmilo Granado

Instituição: Universidade São Judas

Julgamento:

Assinatura:

Profa. Dra. Claudia Aranha Gil

Instituição: Universidade São Judas

Julgamento:

Assinatura:

Prof. Dr. Decio Gurfinkel

Instituição: Instituto Sedes Sapientiae

Julgamento:

Assinatura:

Profa. Dra. Lygia Vampré Humberg

Instituição: Instituto Sedes Sapientiae

Julgamento:

Assinatura: 
À minha avó Elza (in memoriam), pelo jardim, pelas flores e pelos frutos. 


\section{AGRADECIMENTOS}

À professora Leila Tardivo, pela amizade, aprendizado, confiança, cuidado, respeito e generosidade.

À Ivy Martinez, pela ajuda preciosa, pelo cuidado, pela companhia dedicada, pelo brilho inspirador, pelo amor.

À minha família: Claudia, Daniela, Elza (in memoriam), Ilvana, Sérgio e Tiziano (in memoriam), por toda admiração e apoio, sempre.

À Roberta Manna, pela incrível contribuição, pela grandeza e integridade, pela parceria e carinho.

À Isabel Castello Branco Lima, pela presença e pelo cuidado.

À Lia Pitliuk, pela amizade, torcida e paciência durante esse processo.

Ao Decio Gurfinkel, pela amizade, generosidade e troca preciosa.

À Diva Reale, pelo barato da amizade, pela parceria e confiança.

À professora Tania Maria José Aiello-Vaisberg, pela disponibilidade e contribuição.

Ao professor Gilberto Safra e ao Nelson Coelho, pelas contribuições.

Aos amigos do Departamento de Psicanálise do Instituto Sedes Sapientiae, em especial do grupo Sexta Clínica - Ana Carolina Vasarhelyi de Paula Santos, Cristina Ribeiro Barczinski, Déborah de Paula Souza, Deivian Butler, Gisele Senne de Moraes, Ilana Safro Berenstein, Luiz Gustavo Veiga, Marcia Maroni Daher Pereira e Sonia Maria Ramos Mendonça -, pelo espaço fértil e pela amizade.

Aos amigos de estudo Adriana D’Amorim, Carla Junqueira, Clara Castro, Luciana Lafraia, Richard Petric e Rosa Junqueira, pelos anos de aprendizado.

Ao professor Marcos Garcia e a todos os colegas do CRR-UFSCar-Sorocaba (Centro Regional de Referência da Universidade Federal de São Carlos - campus Sorocaba), pela oportunidade tão rica.

A todos os meus alunos e supervisionandos, que tanto me ensinam.

Aos amigos Caio Mantese de Souza, Daniela Adachi Guimarães, Luiz Tadeu Gabriel Filho e Silvia Lopes de Menezes, pelos anos de troca e confiança.

Ao Alexandre Maduenho, pelos anos de aprendizado.

À Tania Possani, pela parceria de tanto tempo.

Ao Mauro Tanaka e à Juliana Fermi, pela amizade, paciência e torcida. 
A Camila Morais, Ellen Cortez, Juliana Carvalho, Maiá Aiello, Mariangela Molina, Tatiana Mata e Vivian Altman, pela confiança e carinho.

A Claudia Gil, Laura Granado, Cidinha, Marcia Isaco e a todos os colegas do APOIAR, pelos anos de aprendizado.

À Marília Velano, pelas aulas magníficas. Merci.

À Carolina Akerman e ao Christian Botelho Borges, pelo excelente apoio técnico e pela presteza.

À Viviane Cirilo e à Elza Bucci, pela amizade e carinho.

Aos amigos da ABRAMD (Associação Brasileira Multidisciplinar de Estudos sobre Drogas) - Clínica São Paulo, pela troca e aprendizado.

A todos os funcionários do Instituto de Psicologia da Universidade de São Paulo (IPUSP), em especial Ana Maria Sanches Garcia, Cícera Eloi dos Santos de Andrade, Claudia Lima Rodrigues da Rocha, Moisés do Nascimento Soares e Sonia (Departamento de Psicologia Experimental - PSE), pela ajuda e pela atenção em vários momentos deste percurso. 
Não existia qualquer referencial de retorno... da mesma forma que o primitivo que não está convencido, ao ver o sol se pôr atrás da montanha, de que o mesmo sol voltará para aquecer e iluminar no dia seguinte.

\section{Jean Bergeret}




\section{RESUMO}

CRUZ, Marcelo Soares da. Adição ao outro em pacientes fronteiriços: Um estudo psicanalítico. 2016. 262 f. Tese (doutorado) - Instituto de Psicologia da Universidade de São Paulo, São Paulo, 2016.

A clínica psicanalítica contemporânea está desafiada a responder a condições emocionais marcadas por estados de solidão, desamparo, desorganização e enfraquecimento da experiência de alteridade, que podem se expressar nos chamados pacientes fronteiriços (borderline). Nesses estados psicopatológicos, descritos na literatura psicanalítica desde a década de 1930, há um componente central que se destaca e que inspirou a presente investigação. Trata-se da angústia de perda de objeto e da busca desesperada pelo outro na esperança de aplacar estados gravemente desestruturantes. Esta tese apresenta ponderações teóricas sobre esses pacientes a partir de importantes autores da psicanálise, além de uma revisão da literatura disponível em bases de dados relevantes, abrangendo pesquisas realizadas nos dez últimos anos sobre adicção e pacientes fronteiriços. Realizada a partir desse aprofundado estudo teórico, esta pesquisa teve o duplo objetivo de refletir sobre a forma de relacionamento estabelecida pelos pacientes fronteiriços e de ampliar a compreensão do drama contido nesse sofrimento. A investigação caracteriza-se como pesquisa psicanalítica qualitativa, desenvolvida com estudo de três casos clínicos: uma mulher de 41 anos, um adolescente de 14 e um homem de 32. Todos foram atendidos em contexto de psicoterapia psicanalítica individual, assim como todas as etapas da pesquisa ocorreram sustentadas pelo método psicanalítico, desde a produção, o registro e o tratamento do material, apresentado na forma de narrativas. Evidenciou-se a predominância de relacionamentos adictivos como marca proeminente da dinâmica dos três casos estudados. Tal dinâmica se manifestou intensamente na relação terapêutica e em outros vínculos na vida dessas pessoas, como se observou pelo relato dos pacientes. Considerando a história e os desenvolvimentos próprios de cada pessoa, esta pesquisa confirmou proposições de autores clássicos da psicanálise, bem como resultados de estudos mais atuais. A pesquisa trouxe, ainda, considerações que favoreceram a compreensão da dinâmica e da estrutura de personalidade de cada uma dessas pessoas, evidenciando-se a necessidade de serem acolhidas, compreendidas e tratadas, em função do intenso sofrimento e da extrema dificuldade que vivem.

Palavras-chave: psicanálise, psicopatologia, borderline, estados-limite, adicção. 


\begin{abstract}
CRUZ, Marcelo Soares da. Adição ao outro em pacientes fronteiriços: Um estudo psicanalítico. 2016. 262 f. Tese (doutorado) - Instituto de Psicologia da Universidade de São Paulo, São Paulo, 2016.

The contemporary clinic is challenged to respond to emotional conditions marked by loneliness states, helplessness, disorganization and weakening of otherness experience, which can be expressed in so-called borderline patients. These psychopathological states, described in psychoanalytic literature since the 1930s, there is a central component that stands out and that inspired this research. It is the anguish of loss of the object and desperate search for another in the hope of placating seriously destabilizing states. We present theoretical placements on these patients from important authors of psychoanalysis, as well as inserting a research literature review conducted in the last ten years of addiction and borderline patients in different databases. From this in-depth theoretical study, this research was conducted in order to reflect on the type of relationship established by the border patients, aiming further broaden the understanding of the drama contained in this suffering. The research is characterized as qualitative psychoanalytic research, developed a study of three clinical cases, a woman of 41, a adolecent of 14 and a man of 32. All were treated in individual psychoanalytic psychotherapy context, as well as all stages of search occurred supported by the psychoanalytic method from the generation, recording and processing of the material presented in the form of narratives. Showed the predominance of addictive relationships as a prominent mark of the dynamics of the three cases studied, which is strongly expressed in the therapeutic relationship, and as noted by the report, other links in their lives. Considering the history and own developments of each person, this research confirmed placements of classical authors of psychoanalysis, as well as the most recent research results. The research has also considerations that favored the understanding of the dynamics and personality structure of each of these people, demonstrating the need to be accepted, understood and treated, due to the intense suffering and extreme difficulty living.
\end{abstract}

Keywords: psychoanalysis, psychopathology, borderline, borderline states, addiction. 


\section{RÉSUMÉ}

CRUZ, Marcelo Soares da. Adição ao outro em pacientes fronteiriços: Um estudo psicanalítico. 2016. 262 f. Tese (doutorado) - Instituto de Psicologia da Universidade de São Paulo, São Paulo, 2016.

La clinique psychanalytique contemporaine est mis au défi de répondre aux conditions émotionnelles marquées par les Etats solitude, l'impuissance, la désorganisation et l'affaiblissement de l'expérience, l'altérité qui peuvent être exprimés chez les patients dits frontières (borderline). Ces états psychopathologiques, décrits dans la littérature psychanalytique depuis les années 1930, il est un élément central qui se démarque et qui a inspiré cette recherche. Il est l'objet de la perte d'angoisse et de recherche désespérée d'une autre dans l'espoir d'apaiser les états sérieux de déstabilisation. Nous présentons des stages théoriques sur ces patients d'auteurs importants de la psychanalyse, ainsi que l'insertion d'une revue de la littérature de recherches menées au cours des dix dernières années de la toxicomanie et des frontières patients dans différentes bases de données. A partir de cette étude théorique approfondie, cette recherche a été menée dans le but de réfléchir sur le type de relation établie par les patients à la frontière, dans le but d'élargir davantage la compréhension du drame contenu dans cette souffrance. La recherche se caractérise par la recherche psychanalytique qualitative, mis au point une étude de trois cas cliniques, une femme de 41 ans, un 14 et un homme de 32. Tous ont été traités dans le contexte de la psychothérapie psychanalytique individuelle, ainsi que toutes les étapes de la recherche est survenue soutenu par la méthode psychanalytique de la génération, l'enregistrement et le traitement du matériel présenté sous la forme de récits. Montré la prédominance des relations de dépendance comme une marque de premier plan de la dynamique des trois cas étudiés, ce qui est fortement exprimé dans la relation thérapeutique, et comme indiqué par le rapport, d'autres liens dans leur vie. Compte tenu de l'histoire et de l'évolution propre de chaque personne, cette recherche a confirmé le placement des auteurs classiques de la psychanalyse, ainsi que les résultats de recherche les plus récents. La recherche a également des considérations qui ont favorisée la compréhension de la dynamique et de la personnalité structure de chacun de ces personnes, ce qui démontre la nécessité d'être accepté, compris et traités, en raison de la souffrance intense et extrême difficulté à vivre.

Mots-clés: psychanalyse, psychopathologie, états limits, borderline, dépendance. 


\section{LISTA DE FIGURAS}

Figura 1. Organização do split (da divisão) - consciência de tudo bom ou tudo mau (CLARKIN; YEOMANS; KERNBERG, 2006, p. 186). 


\section{LISTA DE TABELAS}

Tabela 1. Diferenciação da Organização de Personalidade (KERNBERG, 1995 p. 19) .....71

Tabela 2. Comparação entre as linhagens estruturais (BERGERET, 1991) .75

Tabela 3. Palavras-chave pesquisadas no Scielo: borderline; borderline and psicanálise and adicção; borderline and adicção; borderline and psicanálise; borderline and psychoanalysis; borderline and addiction; borderline and adição.

Tabela 4. Tema e metodologia dos artigos do Scielo sobre "borderline and psicanálise"....110

Tabela 5. Tema e metodologia dos artigos do Scielo sobre "borderline and psychoanalysis"

Tabela 6. Tema e metodologia dos artigos do Scielo sobre "borderline and addiction" ...115

Tabela 7. Tema e metodologia dos artigos do Scielo sobre "borderline and dependência".115

Tabela 8. Palavras-chave pesquisadas no Scielo: "fronteiriço"; "fronteiriço and psicanálise and adicção"; "fronteiriço and adicção"; "fronteiriço and psicanálise"; "fronteiriço and adição"; "fronteiriço and dependência".

Tabela 9. Tema e metodologia dos artigos do Scielo sobre fronteiriço

Tabela 10. Palavras-chave pesquisadas no Scielo: estados limite; estados-limite and psicanálise; estados-limite and psicanálise and adicção; estados-limite; casos-limite; casos limite; caso limite 118

Tabela 11. Tema e metodologia dos artigos do Scielo sobre: "estados limite" 119

Tabela 12. Tema e metodologia dos artigos do Scielo sobre: "estados-limite" 120

Tabela 13. Tema e metodologia dos artigos do Scielo sobre: "casos-limite", "casos limite" e "caso limite"

Tabela 14. Outras palavras-chave pesquisadas no Scielo 122

Tabela 15. Tema e metodologia dos artigos do Scielo sobre "transtorno de personalidade borderline" 123

Tabela 16. Tema e metodologia dos artigos do Scielo sobre "transtorno de personalidade limítrofe" 125 
Tabela 17. Palavras-chave pesquisadas no PubMed: borderline, addiction, borderline and addiction, borderline disorder and addiction, borderline and psychoanalysis, addiction and psychoanalysis, borderline disorder and psychoanalysis, borderline and addiction and psychoanalysis .....

Tabela 18. Tema e metodologia dos artigos do PubMed sobre "addiction and psychoanalysis", "borderline and addiction", "borderline disorder and addiction", "borderline and psychoanalysis".

Tabela 19. Palavras-chave pesquisadas na Biblioteca Digital de Teses e Dissertações da USP: "borderline", "borderline and psicanálise and adicção", "borderline and adicção", "borderline and psicanálise", "borderline and adição", "borderline and dependência".....131

Tabela 20. Tema e metodologia dos artigos da Biblioteca Digital de Teses e Dissertações da USP sobre "borderline"

Tabela 21. Tema e Metodologia dos artigos da Biblioteca Digital de Teses e Dissertações da USP sobre "borderline and psicanálise and adicção".

Tabela 22. Tema e metodologia dos artigos da Biblioteca Digital de Teses e Dissertações da USP sobre "borderline and adicção".

Tabela 23. Tema e metodologia dos artigos da Biblioteca Digital de Teses e Dissertações da USP sobre "borderline and psicanálise", "borderline and adição" e "borderline and dependência". 135

Tabela 24. Palavras-chave pesquisadas na Biblioteca Digital de Teses e Dissertações da USP: "fronteiriço", "fronteiriço and psicanálise and adicção", "fronteiriço and adicção", "fronteiriço and psicanálise", "fronteiriço and adição", "fronteiriço and dependência".....137

Tabela 25. Tema e metodologia dos artigos da Biblioteca Digital de Teses e Dissertações da USP sobre "fronteiriço and psicanálise".

Tabela 26. Palavras-chave pesquisadas na Biblioteca Digital de Teses e Dissertações da USP: "estados limite", "estados-limite and psicanálise", "estados-limite and psicanálise and adicção", "estados-limite", "casos-limite", "casos limite", "caso limite" 138

Tabela 27. Outras palavras-chave pesquisadas na Biblioteca Digital de Teses e Dissertações da USP

Tabela 28. Palavras-chave pesquisadas no Portal de Periódicos da Capes: "borderline", "borderline and psicanálise and adicção", "borderline and adicção", "borderline and psicanálise", "borderline and psychoanalysis", "borderline and addiction", "borderline and adição", "borderline and dependência". 
Tabela 29. Tema e metodologia dos artigos do Portal de Periódicos da Capes sobre "borderline and psicanálise"

Tabela 30. Tema e Metodologia dos artigos do Portal de Periódicos da Capes sobre "borderline and psychoanalysis".

Tabela 31. Tema e metodologia dos artigos do Portal de Periódicos da Capes sobre "borderline and addiction". 144

Tabela 32. Outras palavras-chave pesquisadas no Portal de Periódicos da Capes

Tabela 33. Palavras-chave pesquisadas no Portal de Periódicos da Capes: "estados limite", "estados-limite and psicanálise", "estados-limite and psicanálise and adicção", "estados-limite", "casos-limite", "casos limite", "caso limite" 146

Tabela 34. Tema e metodologia dos artigos do Portal de Periódicos da Capes sobre "estados limite".

Tabela 35. Tema e metodologia dos artigos do Portal de Periódicos da Capes sobre "casos limite" 148

Tabela 36. Outras palavras-chave pesquisadas no Portal de Periódicos da Capes ...... 149

Tabela 37. Tema e metodologia dos artigos do Portal de Periódicos da Capes sobre "transtorno de personalidade borderline" 150

Tabela 38. Refinamento dos resultados e considerações sobre a revisão bibliográfica 152 


\section{LISTA DE ABREVIATURAS E SIGLAS}

ANR anorexia nervosa restritiva

ANP anorexia compulsivo-nervosa / anorexia purgante

BNP purga e bulimia nervosa

Bireme Centro Latino-Americano e do Caribe de Informação em Ciência da Saúde. Conhecido por seu nome original, Biblioteca Regional de Medicina, é um centro especializado da Organização Pan-Americana da Saúde (OPAS) e da Organização Mundial da Saúde (OMS), orientado à cooperação técnica em informação científica em saúde.

ABRAMD Associação Brasileira Multidisciplinar de Estudos sobre Drogas

PSE Departamento de Psicologia Experimental, do Instituto de Psicologia da Universidade de São Paulo (IPUSP)

BAI Beck Anxiety Inventory (Inventário de Ansiedade de Beck)

BDI Beck Depression Inventory (Inventário de Depressão de Beck)

BPI Borderline Personality Inventory (Inventário de Personalidade Borderline)

Capes Coordenação de Aperfeiçoamento de Pessoal de Nível Superior, vinculada ao Ministério da Educação do Brasil.

CNPq Conselho Nacional de Desenvolvimento Científico e Tecnológico, vinculado ao Ministério da Ciência, Tecnologia e Inovação do Brasil.

CRR-UFSCar-Sorocaba Centro Regional de Referência da Universidade Federal de São Carlos - campus Sorocaba. Pertence à rede de Centros Regionais de Referência brasileiros de formação permanente aprovados pela Secretaria Nacional de Política sobre Drogas (SENAD), como parte do Plano Integrado de Enfrentamento ao Crack e Outras Drogas, lançado pelo Governo Federal em 2010.

CTQ-28 Childhood Trauma Questionnaire (Questionário de Trauma de Infância)

DES Dissociative Experiences Scale (Escala de Experiências Dissociativas)

Entrez Global Query Cross-Database Search System (Sistema de Busca Global em Múltiplas Bases de Dados). Metabuscador mantido pelo National Center for Biotechnology Information (NCBI), uma seção da Biblioteca Nacional de Medicina Norte-Americana (NLM).

Fapesp Fundação de Amparo à Pesquisa do Estado de São Paulo 
IAS Internet Addiction Scale (Escala de Dependência da Internet)

IBICT Instituto Brasileiro de Informação em Ciência e Tecnologia, vinculado ao Ministério da Ciência, Tecnologia e Inovação.

IPUSP Instituto de Psicologia da Universidade de São Paulo

Medline Medical Literature Analysis and Retrieval System Online (Sistema Online de Busca e Análise de Literatura Médica). Base de dados bibliográficos da Biblioteca Nacional de Medicina Norte-Americana (NLM).

NCBI National Center for Biotechnology Information (Centro Nacional de Informação sobre Biotecnologia). Divisão da Biblioteca Nacional de Medicina NorteAmericana (NLM) e do Instituto Nacional de Saúde (NIH) dos EUA.

NDLTD Networked Digital Library of Theses and Dissertations (Biblioteca Digital de Teses e Dissertações em Rede). Organização internacional que encoraja a produção de teses e dissertações em formato digital e promove sua preservação e divulgação pela internet, contendo em seu catálogo mais de um milhão de trabalhos atualmente.

NIH National Institute of Health (Instituto Nacional de Saúde dos EUA)

NLM United States National Library of Medicine (Biblioteca Nacional de Medicina Norte-Americana)

OPAS Organização Pan-Americana da Saúde

OMS Organização Mundial da Saúde

PFT Psicoterapia Focada na Transferência, específica para o transtorno borderline, sistematizada por O. F. Kernberg e colaboradores no artigo "Psychotherapy for borderline personality: Focusing on object relations" (2006), em conformidade com os requisitos do Instituto Nacional de Saúde Mental da América.

Unesco United Nations Educational, Scientific and Cultural Organization (Organização das Nações Unidas para a Educação, a Ciência e a Cultura)

USP Universidade de São Paulo

Scielo Scientific Eletronic Library Online (Biblioteca Científica Eletrônica Online) 


\section{SUMÁRIO}

\section{INTRODUÇÃO}

1.1 PANORAMA PSICANALÍTICO SOBRE AS ADICÇÕES NOS PACIENTES FRONTEIRIÇOS . 25

1.2 DiAGNÓSTICO EM PSICANÁLISE E A TERMINOLOGIA “FRONTEIRIÇO” ................... 25

1.3 A INAUGURAÇÃO DE UM NOVO CAMPO EM PSICANÁLISE...................................... 29

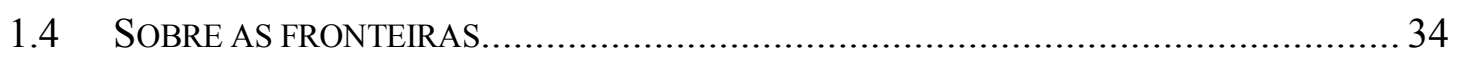

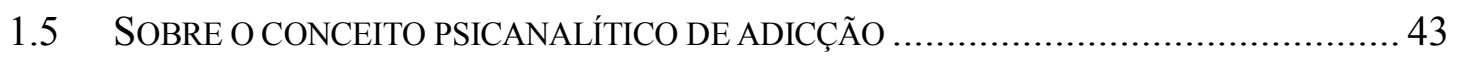

1.6 PANORAMA PSICANALÍTICO: DOS AUTORES CLÁSSICOS AOS CONTEMPORÂNEOS .. 49

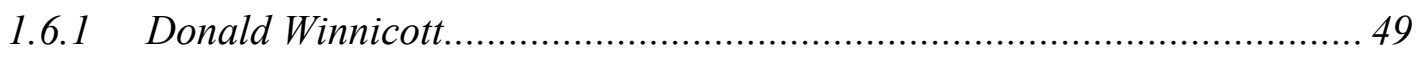

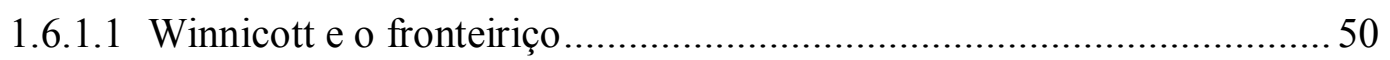

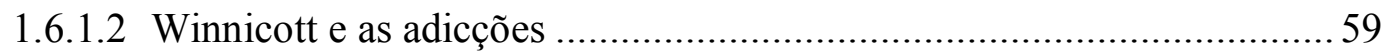

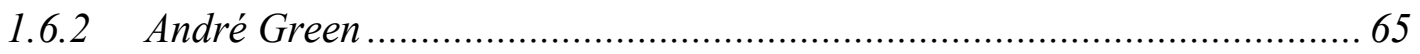

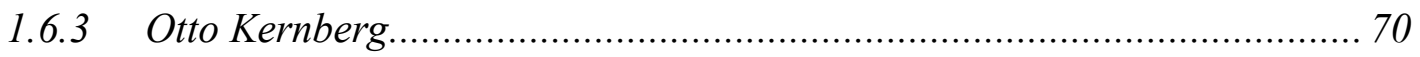

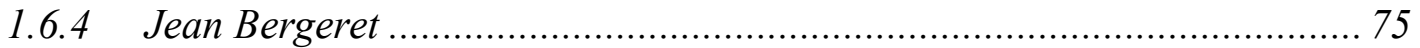

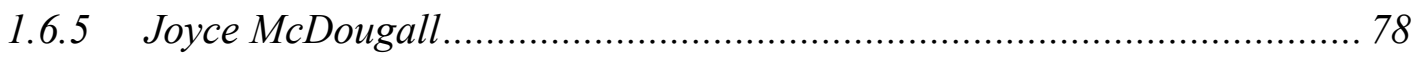

1.6.6 Outros autores da psicanálise contemporânea ....................................... 84

1.7 DELÍRIO, ESPERANÇA, TRANSFORMAÇÃO: APROXIMAÇÕES ENTRE O FRONTEIRIÇO E A ADICÇÃO

\section{REVISÃO BIBLIOGRÁFICA}

2.1 CONSIDERAÇÕES SOBRE A REVISÃO BIBLIOGRÁFICA DOS TEMAS

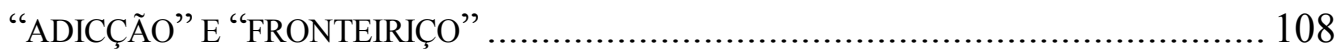

2.2 REVISÃO DA BASE DE DADOS SCIELO ............................................................ 109

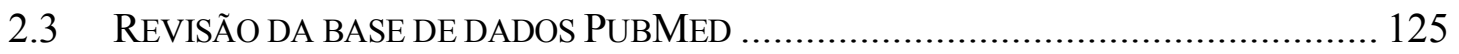

2.4 REVISÃo DA BIBLIOTECA DigITAL DE TESES E DiSSERTAÇÕES DA USP ............. 130

2.5 REVISÃo do PoRTAL de PERIÓDICOS DA CAPES .............................................. 140

2.6 SÍNTESE SOBRE A REVISÃO BIBLIOGRÁFICA DOS TEMAS “ADICÇÃO” E "FRONTEIRIÇO”

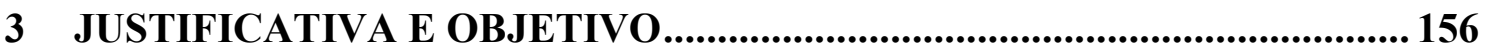

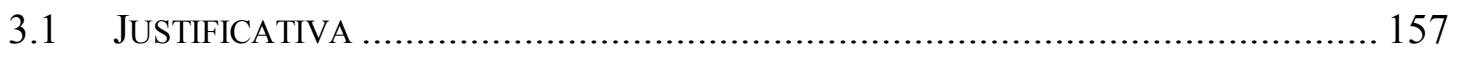

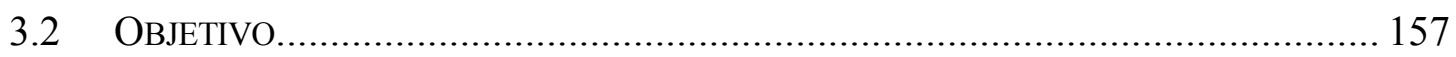

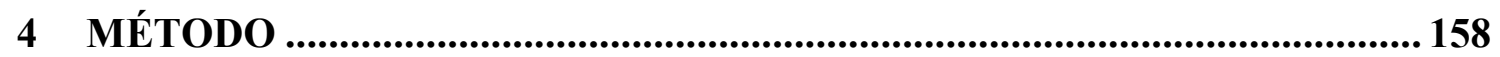

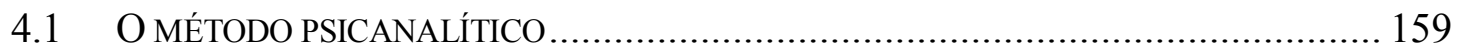

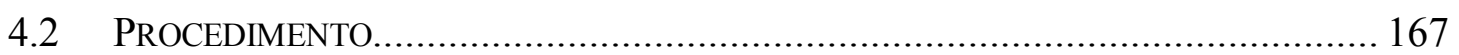

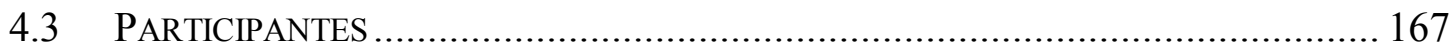




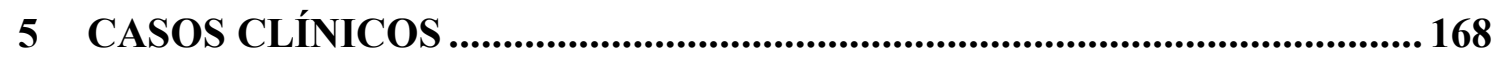

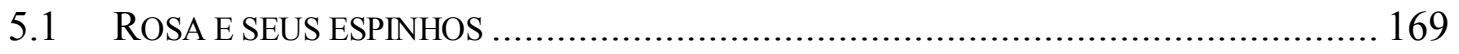

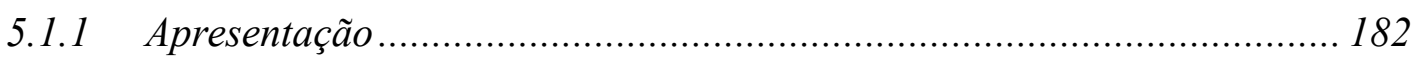

5.1.2 Caso clínico.................................................................................... 182

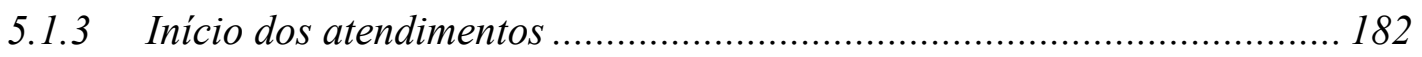

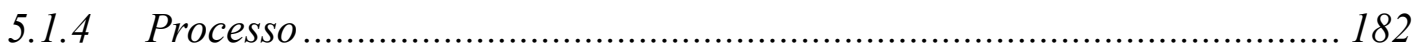

5.1.5 Relexões sobre o material clínico................................................... 182

5.2 TESSITURAS DA ADICÇÃO: DO DESENCANTO AO BRINCAR................................. 192

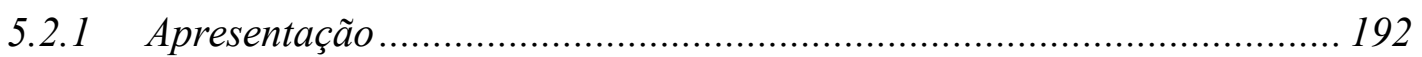

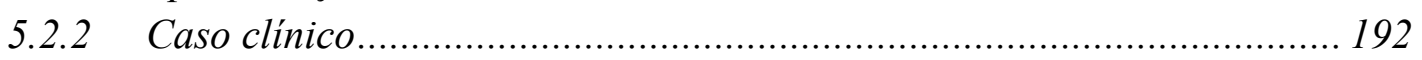

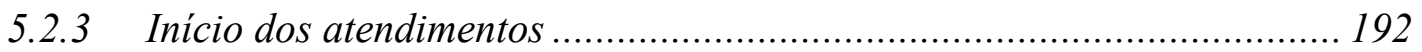

5.2.4 Processo ........................................................................................ 192

5.2.5 Reflexões sobre o material clínico..................................................... 205

5.3 ESPERANÇA E IMPOSSIBILIDADE NA CLÍNICA DA ADICÇÃO ................................ 214

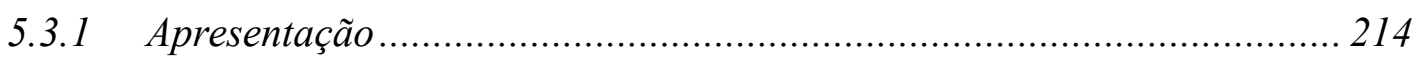

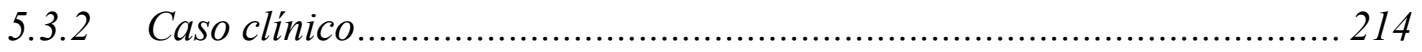

5.3.3 Início dos atendimentos ................................................................... 214

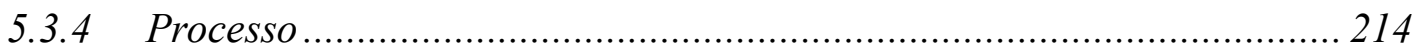

5.3.5 Reflexões sobre o material clínico.................................................... 223

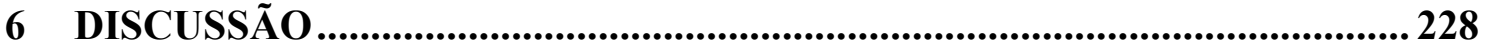

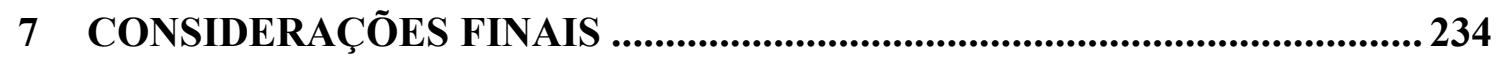

8 REFERÊNCIAS BIBLIOGRÁFICAS........................................................ 237 
Apresentação 
A iniciativa desta pesquisa se deu como um desdobramento de minha dissertação de mestrado, intitulada Reflexões sobre a relação entre a personalidade borderline e as adicções, defendida, em 2012, no Departamento de Psicologia Clínica do Instituto de Psicologia da USP.

Desde o início de minha atividade clínica, venho me debruçando sobre os impasses e particularidades presentes na oferta de cuidado a pessoas com sofrimentos próximos dos estados fronteiriços ${ }^{1}$ e das adicções ${ }^{2}$. O contato com essas condições permitiu apreender que a pungência do sofrimento, que leva o sujeito a buscar externamente um outro, em pacientes fronteiriços é tão intensa quanto em adictos a substâncias ou a quaisquer outros objetos. Porém, aparentemente, nos primeiros, se apresenta de forma mais evidente e exuberante, enquanto, nos segundos, pode ficar disfarçada nos meandros do prazer e da desobjetalização. Dessa maneira, a proximidade da dinâmica dessas formas psicopatológicas gerou interesse em pesquisar suas relações.

$\mathrm{Na}$ clínica das adicções, certas distrações podem encobrir a percepção do desespero e da esperança, tanto ao olhar de quem trata, como de quem sofre. Isso porque, no drama vivido nesses circuitos, o desligamento, a destrutividade e a posição secundária do outro, decorrentes de processos de coisificação ${ }^{3}$, podem camuflar, alienar e fazer perder o fio da meada de um sentido humano, que, a partir do meu percurso clínico e de pesquisa, contemplando tal condição, considero evidentemente presente.

Essa clínica engendrou desafios, a partir de importantes entraves, turbulências e incompreensões, que despertaram o desejo de entender mais profundamente as idiossincrasias dessas condições emocionais. Contratransferencialmente, esses contatos clínicos comunicavam a dimensão de um desespero, ora tocante e comovente, ora violento e disruptivo.

A fala de um paciente ajuda a ilustrar essa clínica de forma encarnada:

Me cortei para não cheirar, para não beber... Quebrei a mão! Não sei o que é isso! Eu sinto que só vago... Vou chutar tudo, hoje vou dormir

\footnotetext{
${ }^{1}$ Neste estudo, os termos "fronteiriço", "borderline", "estado-limite" e derivados serão utilizados para fazer referência ao mesmo grupo de pacientes.

2 Embora o Dicionário Houaiss da Língua Portuguesa (2001) adote a grafia "adição", sem o "cê" mudo, a forma "adicção" é mais corrente na literatura psicanalítica, e essa tradição ortográfica foi respeitada no presente trabalho.

${ }^{3}$ Gurfinkel $(1995,2001,2011)$ utiliza o termo "coisificação" para designar essa desobjetalização do humano, tendência de degradação da qualidade da relação objetal.
} 
na rua... Não suporto respirar... Não aguento mais... Achei que nunca mais pensaria nisso... Se você não me atendesse hoje eu acabaria com tudo!

Rodrigo contava 19 anos de idade na época, estava em tratamento havia cinco anos e já não usava cocaína por certo tempo. Esse atendimento ocorreu após ele ter me ligado de madrugada dezenas de vezes em um fim de semana prolongado, no qual sua mãe e seu padrasto viajaram. Essa breve vinheta evidencia de forma viva o desespero e a vivência de perda presentes nos estados fronteiriços e nas adicções. A radicalidade da ausência objetal e a consequente desorientação do paciente, no auge de seu sofrimento, expõem a tentativa desesperada de supressão da perda e a intensidade do contato clínico.

No caso desse paciente, a adicção à droga e ao outro eram elementos coincidentes, porém é importante frisar que nem todo paciente fronteiriço adere necessariamente a uma substância, como nem toda adicção se dá nos casos borderline. O olhar que proponho e pretendo desenvolver é que o paciente fronteiriço, ao menos em alguns casos, padece de uma condição adictiva ao outro. Nesse contexto, a adicção se dá a uma pessoa de fato, tomada como objeto coisificado, nos moldes da dependência a uma droga, cujos traços humanos e pessoais não consistem em referências determinantes de busca e relação. Dessa forma, o outro e uma substância parecem carregar a mesma condição de objeto buscado para cumprir uma função de caráter similar.

A procura desesperada de muitos pacientes por algo ou alguém capaz de aplacar estados gravemente desestruturantes é que mobilizou em mim o desejo de realizar essa investigação, iniciada com o trabalho de mestrado. Ao pesquisar a relação entre os pacientes borderline e as adicções, a compreensão construída ao final da dissertação culminou na concepção de que o fronteiriço pode constituir uma modalidade de adicção, ao menos em alguns casos. Essa compreensão tornou-se ponto de partida do presente trabalho, cuja estrutura está resumida abaixo.

O primeiro capítulo apresenta um panorama psicanalítico sobre as adicções nos pacientes fronteiriços, bem como reflexões sobre diagnóstico em psicanálise e uma justificativa para a escolha da terminologia "fronteiriço". Também trata da inauguração de um novo campo em psicanálise a partir do conceito do fronteiriço, além de circunscrever o conceito psicanalítico de adicção, discorrer sobre a abordagem de autores clássi- 
cos e contemporâneos sobre o tema e traçar aproximações entre o fronteiriço e a adicção.

O capítulo dois oferece uma revisão bibliográfica comentada acerca dos temas "adicção" e "fronteiriço", contemplando também terminologias afins. Essa revisão foi realizada a partir de buscas nas bases de dados Scielo (Scientific Eletronic Library Online), PubMed, Biblioteca Digital de Teses e Dissertações da USP e Portal de Periódicos da Capes (Coordenação de Aperfeiçoamento de Pessoal de Nível Superior).

O capítulo três expõe a justificativa e os objetivos que orientam a presente pesquisa, ao passo que o capítulo seguinte se ocupa do método, dos procedimentos e dos participantes.

O quinto capítulo, dedicado ao material clínico, apresenta três estudos de caso e algumas reflexões, que se desdobram em discussão no capítulo seis. Por fim, o capítulo sete encerra, com as considerações finais, este trabalho sobre a adicção do fronteiriço ao outro. 
Capítulo I

Introdução 


\subsection{PANORAMA PSICANALÍTICO SOBRE AS ADICÇÕES NOS PACIENTES FRONTEIRIÇOS}

O drama contido no sofrimento dos pacientes fronteiriços pode expressar-se tanto pela compulsão adictiva a uma substância, como por apelos de grande intensidade e turbulência voltados à manutenção da presença de uma pessoa ou da ligação com ela. Nessa condição psicopatológica, ganha destaque o componente adictivo, nos moldes de um vício ao outro. Tal busca se apresenta na forma de uma compulsão relacionada fundamentalmente à excruciante ausência objetal e aos instáveis contornos do Self (STERN, 1938; KERNBERG, 1991; BERGERET, 1998; GREEN, 1988).

Neste capítulo será apresentada reflexão, a partir de autores clássicos e contemporâneos da psicanálise que se debruçaram sobre o tema do fronteiriço, sobretudo aqueles que oferecem subsídios teóricos para o estudo da relação entre os pacientes fronteiriços e as adiç̧ões, questão investigada em dissertação de mestrado (CRUZ, 2012) defendida pelo autor desta tese.

\subsection{DIAGNÓSTICO EM PSICANÁLISE E A TERMINOLOGIA "FRONTEIRIÇO"}

A partir de sua experiência clínica e dos conceitos produzidos em sua obra até então, Freud apresentou em 1904 algumas orientações e critérios para a seleção de casos, destacando a necessidade de uma compreensão diagnóstica anterior ao início do tratamento. Em 1913, evidenciou a relevância de um primeiro momento de entrevistas e de seleção prévia a fim de realizar a distinção dos pacientes que poderiam ser submetidos ao método psicanalítico.

Bergeret (1998) compreende que cada estrutura e organização de personalidade manifesta um tipo de angústia básica peculiar, indicando a importância de intervenções específicas diante de distintas manifestações. Para o autor, a definição de personalidade abarca o que há de mais significativo e permanente no indivíduo - a base a partir da qual se desdobram as potencialidades em condições consideradas normais, ou se manifesta a patologia. O pensador utiliza referenciais metapsicológicos a fim de nortear a 
diferenciação das estruturas e organizações. Considera que manifestações como as defesas mais utilizadas, o grau de desenvolvimento do Ego e das pulsões, o modelo de relação objetal e a angústia organizadora são constituídos como fruto da história pregressa e da jornada singular que compõe a trama psíquica de cada indivíduo.

Segundo Bergeret (1998), observando apenas a expressão sintomática não é possível diagnosticar com profundidade a organização estrutural da personalidade, pois o sintoma revela o funcionamento patológico de uma estrutura que se apresenta descompensada. Esse aporte assinala a distinção de dois campos relevantes da psicopatologia: a psicopatologia descritiva e a psicopatologia compreensiva.

Neste prisma, conforme frisam Aiello-Vaisberg e Machado (2000), as contribuições psicanalíticas sobressaem por distinguir com clareza duas instâncias: de um lado, a perspectiva sintomatológica, que pertence ao registro superficial, descritivo e manifesto; de outro, a perspectiva latente da estrutura de personalidade, que inclui as angústias, defesas e fantasias que não podem ser retidas de modo direto pela consciência. Assim sendo, os sintomas conservam valor relativo na apreensão diagnóstica, pois, sejam eles neuróticos ou psicóticos, podem aparecer em qualquer estrutura de personalidade. Ou seja, qualquer indivíduo pode ser acometido pela experiência de qualquer uma das formas de ansiedade, sendo a manifestação sintomática meramente uma defesa que não revela em si a angústia pela qual foi gerada. Dessa forma, o olhar que considera apenas o sintoma perde destaque na clínica contemporânea, uma vez que indivíduos que apresentam angústia central de aniquilamento e destruição do Self podem apresentar sintomas obsessivos, sem que o arranjo psicopatológico seja da ordem do conflito psíquico, por exemplo.

Herrmann (1979) e Bergeret (1998) defendem um referencial que adota a angústia central como critério fundamental para o diagnóstico. Em concordância com esse conceito, Aiello-Vaisberg (1999/2004) acrescenta que cada tipo de sofrimento requer do analista ou terapeuta diferentes modos de intervenção, sem que isso ocasione a supressão da precisão e do rigor do método psicanalítico. Portanto, é imprescindível, diante desse posicionamento, a apreensão do drama experimentado em tal sofrimento. Assim, a oferta de cuidado é drasticamente diferente para um indivíduo que vive angústia de perda de objeto, castração ou aniquilamento. Esse posicionamento é fundamental para a presente pesquisa em psicopatologia, dado que o método psicanalítico ganha destaque e 
estabelece-se frente aos dramas e às diversas formas de tratamento, consoante a psicopatologia envolvida.

Kernberg (1991, 1995) e Clarkin, Yeomans e Kernberg (2006) entendem a estrutura psíquica do paciente como base sobre a qual se desenvolvem os sintomas, e as características dominantes do indivíduo refletem o tipo de organização. Por meio das descrições fenomenológicas ou comportamentais de cada caso é possível acrescer, complementar e aprimorar o diagnóstico. Kernberg (1991) utiliza vários critérios que auxiliam na diferenciação das estruturas, como o grau de integração da identidade, teste de realidade preservado e organização defensiva, no caso dos neuróticos; predomínio de defesas primitivas e perda importante no teste de realidade, no caso dos psicóticos; e o teste de realidade preservado com defesas primitivas, no caso dos pacientes borderline.

Em consonância com essas concepções diagnósticas, Paz (1976) destaca a importância do que acontece ao longo do percurso da vida, das relações estabelecidas, das marcas libidinais fixadas na infância e de localizações tópicas na constituição de cada sujeito. Assim, é possível apreender que o conceito de personalidade é caracterizado por um conjunto de experiências emocionais, que por sua vez podem gerar marcas de sofrimento e amadurecimento. Assim, cada indivíduo se constituirá de maneira singular diante da jornada trilhada e em função das misérias vividas.

Dentre as diversas formas de apuração, investigação e intervenção, aspectos fundamentais da psicanálise podem ser aplicados com objetivos distintos. No caso de pacientes com a sintomatologia de ordem neurótica, a intervenção clássica empregada por Freud é a elaboração e enunciação de sentenças interpretativas. Porém, em pacientes que apresentam um conjunto de questões de origem mais regressiva, como no caso dos borderlines ou psicóticos, existe a necessidade de adaptações do setting padrão. Herrmann (2004) postula que embora os tipos de intervenção possuam diferenças da análise padrão, conservam-se substancialmente psicanalíticas, ao passo que o tratamento é orientado por meio da busca dos elementos emocionais intrínsecos às produções do paciente. O método, portanto, é único e invariável - o que se modifica é o manejo, assim como a intervenção utilizada. O método é sempre interpretativo, porque compreensivo, orientado pela consideração dos campos transferencial e contratransferencial, ou seja, do impacto afetivo emocional que o paciente desperta no terapeuta. 
Esse olhar, baseado em diagnóstico compreensivo, dá sustentação para a discussão de condições emocionais singulares circunscritas às terminologias ora lançadas. A presente pesquisa se baseia justamente neste ponto de vista, segundo o qual todo trabalho clínico orientado pelo método psicanalítico é necessariamente produto de encontros inter-humanos (TARDIVO 2004; TARDIVO; GIL, 2008; TARDIVO et al., 2010). Dessa forma, as abstrações das nomenclaturas diagnósticas consistem necessariamente em construções advindas de experiências concretas do campo transferencial. Essas experiências, derivadas de encontros intersubjetivos, ganham contorno em terminologias variadas, ainda muito genéricas, que sempre irão requerer singularização caso a caso. Tal postura marca um posicionamento frente ao sofrimento emocional e destaca a oposição a fazeres reducionistas relacionados aos dramas humanos.

Com essas considerações preliminares, os conceitos de "fronteiriço" e "adicção" serão utilizados ao longo desse trabalho. Especificamente sobre o fronteiriço, uma gama de terminologias afins perfilará a partir das produções de autores distintos. Contudo, todas terão como eixo a concepção de fronteiriço. De qualquer modo, há preocupação de evitar a restrição de experiências complexas e polissêmicas a qualquer classificação ou terminologia, seja psiquiátrica, seja psicanalítica, sobre o sofrimento borderline. Com esta preocupação será apresentada a opção terminológica ora adotada.

O termo "fronteiriço", do inglês borderline (Stern, 1938), surge e ganha relevância nas obras de Winnicott (1969/1975), Kernberg (1975) e Green (1988b), por se referir à fronteira, à margem ou ao limite, não apenas das estruturas, mas principalmente pela fragilidade dos contornos do Self. Essa problemática era vista como uma falta de lugar de certas manifestações em relação à classificação mais tradicional das estruturas (neurose, psicose e perversão) e continha traços das três.

De acordo com Figueiredo (2003), nos Estados Unidos e Inglaterra vinham sendo usados, principalmente, os termos "personalidade-limite" (borderline personality) ou "paciente-limite" (borderline-patient), e também o termo "condições-limite", que em português foi traduzido como “caso-limite”. Já na França têm sido usados, principalmente, os termos "estados" ou "situações-limite", porém, de qualquer maneira, essa divisão em termos geográficos não é homogênea, apesar de ser predominante.

Neste trabalho, será adotado principalmente o termo "fronteiriço" (borderline), tendo em vista a imprecisão diagnóstica presente na expressão "caso-limite", que pode 
ser aplicada a diversos quadros psicopatológicos. Da mesma maneira, os termos "estado-limite" ou "situação-limite", mais presentes nos autores franceses, dão ênfase ao fator temporal: as ocasiões ou períodos - de regressões momentâneas, por exemplo nos quais a manifestação borderline ocorre mais claramente na história de uma pessoa, sem relação necessária com diagnóstico específico.

A preferência pelo termo "fronteiriço" não se dá pela via da discriminação entre neurose e psicose, como aquele quadro que se configura entre as duas estruturas, mas devido ao estatuto de organização psíquica dotada de características próprias (CLARKIN; YEOMANS; KERNBERG, 2006; GREEN, 1988b). Sua escolha não caracteriza recusa dos outros termos - também empregados, eventualmente - , mas sim pela singularidade etiológica que o adjetivo "fronteiriço" guarda e por se afastar de sentidos que possam ser confundidos com fenômenos transitórios (CLARKIN; YEOMANS; KERNBERG, 2006; KERNBERG, 1995a, 1991).

\subsection{A INAUGURAÇÃO DE UM NOVO CAMPO EM PSICANÁLISE}

Desde o século XIX, consta da literatura sobre a clínica psiquiátrica a aparição de casos que habitavam a fronteira entre a loucura e a normalidade, marcados principalmente por grave instabilidade de humor, traços contraditórios de personalidade e possibilidade de mimetizar diversos quadros (DALGALARRONDO; VILELA, 1999; STONE, 1990, 1980; GUNDERSON, 1984; GRINKER et al., 1968). Os sintomas eram muito parecidos com os da psicose, porém os pacientes eram descritos como capazes de manter certo contato com a realidade, sem desintegração total (FIGUEIREDO 2006, 2003; BOLLAS, 2000; GABBARD, 1998; GREEN, 1990, 1988b). Para caracterizar esse quadro, circulavam no início do século XX terminologias como insanidade moral, insanidade psicossensorial, loucura raciocinal, folia histérica, folia parcial, monomania, insanidade limítrofe, pré-psicose, personalidade hebefrênica, psicoses marginais, paranoia sensitiva, esquizofrenia pseudoneurótica, pan-neurose, esquizofrenia ambulatória, caráter psicótico e pan-ansiedade (LONDOÑO PAREDES, 2014; BERGERET, 2006, 1998; DALGALARRONDO; VILELA, 1999; GABBARD, 1998; KERNBERG, 1984; KNIGHT, 1953). 
O conceito de fronteiriço também é herdeiro dos desdobramentos da história e da abordagem psiquiátrica da loucura. Pinel (2005/1881), no século XIX, estabeleceu uma divisão entre as loucuras gerais e as parciais. O primeiro grupo dizia respeito aos sujeitos que manifestavam delírios e alucinações relacionados a diversos conteúdos e objetos, produções psicopatológicas exuberantes com grave alienação. O segundo grupo, também chamado de monomania, cuja etimologia significa "loucura única" (ESQUIROL, 1989/1838; PORTOCARRERO, 2002), era composto por pacientes que sentiam, pensavam e agiam como a maioria das pessoas. Além disso, eram capazes de explicar seus comportamentos mais excêntricos com certa crítica e argumentos bem elaborados.

Esquirol (1989/1838) nomeou essas condições de "monomanias pensantes" e "monomanias sem delírio", presentes em indivíduos com condutas impulsivas, mas que não deliravam e tampouco apresentavam sinais evidentes de alienação. Aparentemente, o pensamento e a coerência dessas pessoas permaneciam preservados até certo ponto. Ulysse Trélat, apresentado por Londoño Paredes (2014), concebeu em 1861 a noção de loucura lúcida, do francês folie lucide, derivada de pesquisa realizada com mulheres internadas no hospital Salpêtrière, com as quais conseguiu estabelecer uma conversa clara e coerente na maior parte das ocasiões. Em 1884, o médico americano Charles Hughes (1984/1884) apresentou a expressão "borderland insanities", ou "loucuras da fronteira" ${ }^{\prime}$, para se referir às loucuras parciais que habitavam a fronteira entre a normalidade e a perda da razão.

Dessa forma, torna-se possível apreender, através de fragmentos da história, a aparição da referência de uma patologia da fronteira que foi ganhando atenção e investimento, em especial pela psicanálise. Assim, a concepção do fronteiriço consiste no resultado de uma série de inquietudes presentes no início da psicanálise, relacionadas a esses pacientes difíceis, difusos em diversas terminologias, e seus insucessos terapêuticos (LONDOÑO PAREDES, 2014). Dentro da produção psicanalítica, a partir dos anos 1930, surgiram descrições de pacientes que apresentavam toda fenomenologia de uma psicose, porém não estavam suficientemente doentes ou perturbados demais a ponto de impedir o tratamento psicanalítico clássico. Por outro lado, manifestavam traços de caráter disruptivos, que impediam o sucesso do percurso terapêutico. Tais indivíduos não

\footnotetext{
${ }^{4}$ Tradução minha.
} 
se encaixavam em nenhum quadro concebido por Freud, pois os mecanismos de defesa mais comuns, como o recalque na neurose, a projeção na psicose e a negação na perversão pareciam não estar claramente presentes nas dinâmicas descritas até então pelo criador da psicanálise e ainda não eram suficientemente reconhecidos para definir uma organização psicopatológica.

Freud discriminou os mecanismos que estruturavam cada uma das organizações psíquicas e buscou estabelecer as constantes que as determinavam. Com sua vasta e fundante teorização sobre as psicopatologias, reconheceu condições que se cristalizam em relação ao uso de diversos mecanismos de defesa e sintomas (FREUD, 1992/1931). A teoria da libido e seus destinos, presentes em diferentes estruturas, se mostravam insuficientes para diagnosticar uma série de pacientes que pareciam romper com esses esquemas e escapavam da inclusão na lógica estrutural. Do desencontro entre as manifestações observadas nesses pacientes e a referência estrutural clássica, nasceu o conceito de neurose de caráter, que por um lado se dava como uma formação reativa do paciente ao tratamento e, por outro, como a noção de uma personalidade patológica (LONDOÑO PAREDES, 2014).

O termo "transtorno de personalidade", adotado pela psiquiatria, assim como a palavra borderline, são herdeiros de um problema abordado pela psicanálise desde o início do século XX. Trata-se do papel do caráter como meio de resistência à cura. Freud (1996/1908) identificou o caráter parcimonioso, sistemático e persistente de alguns neuróticos obsessivos e relacionou esses traços à incontinência fecal característica da fase anal, devido ao prazer ligado à retenção promovido nessa zona erógena. $\mathrm{O}$ erotismo anal demonstra como o superinvestimento pulsional de certas zonas erógenas pode favorecer o surgimento de determinado caráter - nesse caso, para Freud, o paciente sofreria de excessiva busca por limpeza. Na neurose histérica, por exemplo, o caráter histriônico se destaca por certa manipulação, teatralidade e afronta, assim como a fobia se caracteriza pela evitação. Todos se associam, a seu modo, a diferentes investimentos pulsionais, de forma que o caráter seria o resultado de sublimações das pulsões e suas formações reativas.

Em 1917, Freud (1996/1917) apontou as resistências do caráter em relação à análise do significado dos sintomas e das moções pulsionais nos processos psicanalíticos. Em especial, tratava-se de sujeitos cujo caráter se destacava no processo de cura 
como forma de entorpecer a possibilidade do trabalho associativo relacionada ao sintoma. Nessa direção, Abraham (1970/1924) publicou em 1924 um estudo sobre a existência de um tipo específico de paciente que resistia à cura psicanalítica. Descrevendo-os como pessoas sem iniciativa, o autor observa que necessitavam ser motivados para tudo, inclusive para realizar as associações durante a análise. Abraham faz importante ressalva ao sugerir que, antes de abordar os sintomas neuróticos, torna-se necessário considerar e tratar o caráter desses pacientes.

Para Laplanche e Pontalis (2001), nas neuroses de caráter não existe a formação de um sintoma claramente identificado, mas este se manifesta por características de caráter, condutas específicas ou uma organização do conjunto da personalidade. Nesse caso, as defesas se integram ao Eu e se diferenciam do sintoma, de modo que tais pacientes desconhecem o aspecto patológico de seus traços de personalidade ou não se queixam deles. Com isso, o sintoma é muitas vezes banalizado e negado. Uma característica importante das neuroses de caráter, apontada por Londoño Paredes (2014), diz respeito à atribuição maciça de todo mal-estar subjetivo ao objeto.

O conceito de neurose de caráter, ao ser apropriado pela psicanálise norteamericana, foi rebatizado como "transtorno de caráter" e, em seguida, como "transtorno de personalidade", terminologia que permanece em uso até hoje, principalmente no campo da psiquiatria. De acordo com Londoño Paredes (2014), a psicanálise americana sempre preferiu o termo "personalidade" à palavra "caráter". Dessa maneira, foram ganhando lugar os casos que surgiam fora da dicotomia diagnóstica neurose-psicose. A derivação mais significativa desse percurso conceitual foi o estabelecimento da noção de fronteiriço.

A partir de certo ponto da história da psicanálise, começou a surgir uma série de produções com descrições de casos cujo diagnóstico e tratamento eram difíceis. Por exemplo, Hosch e Polatin (1949) observaram nos anos 1940 pacientes com aparência esquizofrênica e pseudodefesas neuróticas, mas que mantinham defesas típicas da psicose como traços autísticos e perda transitória da realidade, quadro que os autores denominaram de "esquizofrenias pseudoneuróticas". $\mathrm{Na}$ mesma época, Deutsch (1942/1986) expôs diversos casos de sucesso relacionados a pessoas que apresentavam grave fragilidade emocional e afetiva, próprias de suas organizações de personalidade. Além dessa impermanência afetiva, a autora menciona que careciam de traços genuínos, 
apoiadas em identificações superficiais que lhes atribuíam um aspecto de normalidade. Porém, uma vez abaladas essas identificações, irrompiam sinais evidentemente psicóti$\cos$.

Nas décadas de 1950 e 1960, esses pacientes foram sistematicamente abordados na literatura psicanalítica, até que Kernberg (1967) deu um importante passo ao construir a descrição de um quadro com características próprias e singulares, com lugar próprio na nosografia psicanalítica e psiquiátrica, denominado organização borderline de personalidade. Este conceito influenciou tanto a psiquiatria como a psicanálise de forma contundente, acompanhado das produções igualmente fundantes de Winnicott (1963), André Green (1988) e Jean Bergeret (1990).

Contudo, três décadas antes dos estudos de Kernberg, Adolph Stern já se debruçara pioneiramente sobre esses estados psicopatológicos, percebidos havia muito tempo, mas excluídos da nosologia clássica (STERN, 1938/1986; PEREIRA, 1999). Stern, que havia sido paciente de Freud, foi um dos primeiros introdutores da psicanálise nos Estados Unidos e veio a ser presidente da Sociedade de Psicanálise de Nova Iorque. Em 1938, criou e apresentou pela primeira vez o termo "borderline" (fronteiriço), traduzido para o francês como cas limites (casos-limite) ou états limites (estados-limite) (BERGERET, 1998).

Em seu artigo "Investigação psicanalítica e terapia do grupo de neuroses borderline”, Stern (1938/1986) destacou a marcante característica narcísica desses pacientes, entendendo-a como uma defesa contra o iminente risco de desintegração. O psicanalista americano descreveu, como marca transferencial pungente, um traço central da psicopatologia do fronteiriço: a profunda dependência em relação ao analista, com características peculiares e distantes de uma dependência pacífica, pois o ódio comparecia voltado contra a relação terapêutica.

Nesse trabalho inaugural sobre o fronteiriço, Stern destacou o desamparo radical e uma lancinante necessidade de intensificação da ligação com o outro. Tais pacientes experimentavam o analista como uma presença vaga e sem forma definida, próxima de uma figura mágica e idealizada, que serviria de receptáculo para suas projeções. Demandavam amor e lançavam intensos apelos por cuidado, porém com uma espécie de mensagem paradoxal de repúdio à dependência e à extrema necessidade da presença do outro. Stern (1938) afirmou que a terapêutica psicanalítica tradicional não era efetiva 
para tais pacientes, pois suas dores não residiam na problemática sexual, mas predominantemente no sofrimento narcísico. Portanto, tratava-se de uma condição mais próxima da psicose, ou das neuroses narcísicas, do que das neuroses de transferência. Porém, no quadro fronteiriço, diferentemente da psicose, não havia falhas no teste de realidade da ordem de delírios ou alucinações. Segundo o autor (1938, p. 158):

\begin{abstract}
Meus pacientes, como mencionado acima, constituem um amplo grupo indefinido entre psicoses e neuroses de transferência, compartilhando características de ambas, embora mostrem inclinações nítidas para psicose: lembro que costumamos chamar certas psicoses de "neurose narcísicas". Esse grupo limítrofe revela a presença de narcisismo num grau inexistente no tipo comum de pacientes neuróticos. Seu quadro inteiro fundamenta-se no narcisismo.
\end{abstract}

Dentre diversos componentes mantidos, explorados e ampliados por outros autores, Stern (1938/1986) inaugurou um campo amplamente fecundo para a psicanálise, com o qual qualquer terapeuta está desafiado a lidar nos dias de hoje. Como características que se mantiveram e que serão relevantes no presente estudo, esse psicanalista apontou a fragilidade da identidade que não evolui para a psicose, a angústia de desintegração, demandas excessivas em relação ao outro e dificuldades no teste de realidade, particularmente em relacionamentos pessoais. A partir de Stern, diferentes terminologias surgiram para fazer referência a esses pacientes, que compõem a problemática do presente trabalho. Tal inauguração é importante, não apenas pela classificação ou categorização em uma nova nosografia psicanalítica, mas porque permite que o sofrimento desses pacientes seja considerado e cuidado, a partir do reconhecimento de sua existência e de um novo estatuto psicopatológico.

\title{
1.4 SOBRE AS FRONTEIRAS
}

A circunscrição do conceito de fronteiriço consiste em um desafio para a psicanálise contemporânea. Por um lado, devido à origem derivada de uma diversidade de terminologias incompatíveis com entidades clínicas tradicionalmente estabelecidas; por outro, pela necessidade de estabelecimento de um estatuto próprio, para além de uma 
condição de fronteira, situada entre referências diagnósticas com marcas definidas, de acordo com Kernberg (1991, 1995) e Green (1988).

Green (1988) aponta um problema relacionado ao desenvolvimento do conceito em psicanálise devido à insuficiência da definição de dicionários e verbetes. Para o autor, o fundamental é a distinção entre ter alguma coisa fronteiriça e ser fronteiriço (GREEN, 1988, p. 68). No texto "O conceito do fronteiriço", ele faz uma reflexão sobre a terminologia baseada em referências topográficas, vinculada à noção de fronteira, limite e borda, e aponta que a relevância desse espaço-limite reside na consideração e no destaque da falência de uma terceira área. Para Green, quando o espaço é dividido em duas partes com propriedades opostas, instaura-se um terceiro território. Essa região é composta pelas características das duas outras, porém não é nem uma nem outra, mas um novo registro. Trata-se do espaço intermediário, do entre, conceitualizado por Winnicott (1971), área que dá acesso à possibilidade de elaboração e simbolização, lugar de paradoxo e coexistência. A noção de limite baseada em um terceiro espaço dará sustentação para a compreensão do sofrimento ora abordado e permitirá articulação entre fronteiriço e adicção.

Dessa forma, torna-se possível reconhecer que essa condição psicopatológica, circunscrita sob a terminologia "borderline", não diz respeito apenas a uma fronteira, mas consiste em um lugar, região com marcas próprias e definida pela positividade do acontecimento psíquico, mais do que um quadro baseado na referência "nem este, nem aquele”. Figueiredo (2006, p. 6) destaca que tais pacientes difíceis, inicialmente tidos como refratários à psicanálise, eram casos definidos como "nem, nem, nem", pois não cabiam nas rubricas de neurose, psicose ou perversão. Desde então, constatou-se que o termo borderline continha um amplo espectro de características, e assim a lógica "nem, nem, nem" não era suficiente para a delimitação de fronteiras internas e externas do conceito. De qualquer maneira, o quadro fronteiriço requer discriminação de outras referências diagnósticas, justamente por ocupar um lugar de interseção e mimetismo (FIGUEIREDO, 2006).

A abordagem da relação do fronteiriço com quadros diagnósticos vizinhos tais como personalidades narcísicas, histeria, perversão e psicose - pode ser útil em termos de delimitação do conceito. Contudo, o objetivo desta pesquisa seria distorcido devido à vastidão que este campo comporta. Portanto, algumas considerações acerca de 
discriminações essenciais serão apresentadas como forma de clarificar o que é próprio do fronteiriço.

A perversão, uma vizinhança que requer atenção e discriminação, consiste em um eixo conceitual comumente confundido com o fronteiriço. Na direção do estabelecimento de uma precisão diagnóstica, Kernberg (1995) apresenta uma contribuição fundamental para tal diferenciação. A partir de um ponto de vista neoestruturalista da psicanálise, o autor exclui a perversão das referências estruturais, ou seja, ele a retira do estatuto de estrutura perversa e a compreende como um componente presente potencialmente em todas as organizações de personalidade, com diferentes gradações - desde a perversão própria da sexualidade perversa polimorfa normal, na organização neurótica e, principalmente, na organização borderline. De maneira bastante alinhada com o pensamento freudiano, seu olhar comporta também as referências da escola das relações de objeto, que aborda a problemática pré-edípica, assim como a relação mãe-bebê, como componentes etiológicos da perversão. Resumidamente, propõe que, do ponto de vista estrutural, a perversão está contida, principalmente, na organização borderline. Além disso, considera que a perversão assumiu manifestações ainda mais graves, presentes, por exemplo, nas personalidades narcísicas, narcisismo maligno manifestado nas formas de psicopatia e tendência antissocial e, de forma mais extrema, na psicose.

Kernberg (1995) aponta que nas neuroses as cenas perversas são produto da ação do superego, que estabelece per si a perversão como derivação de proibições inconscientes relacionadas à sexualidade genital, figuradas como incesto e remetidas à angústia de castração. Assim, a perversão presente na organização neurótica assume o valor de proteção contra a irrupção desmedida de agressividade e a consequente degradação das relações objetais.

No fronteiriço, diferentemente, reside uma condensação de componentes edípicos e pré-edípicos, porém com a diferença fundamental de que esses elementos e conflitos estão submetidos sobretudo à égide da agressão pré-edípica - portanto, reconhecida como perversão. Um traço básico dessa discriminação está no fato de os conflitos agressivos predominarem sobre os libidinais. No caso do fronteiriço, a perversão não se baseia no modelo da sedução infantil e há um empobrecimento das fantasias sexuais. Dessa forma, o fronteiriço chama atenção pela ausência da fantasia como elemento estruturante, condição radicalmente oposta à neurose (KERNBERG, 1995; GREEN, 2002). 
Outro eixo que merece luz para uma delimitação mínima do fronteiriço reside na consideração da fronteira com a histeria. A diferenciação entre histeria e fronteiriço é relevante devido ao gradual desaparecimento da histeria do campo da psicopatologia, assim como ao surgimento do fronteiriço como uma espécie de receptáculo diagnóstico de diversas condições clínicas, concomitantemente ao progressivo desaparecimento da histeria na história da psicanálise. De acordo com Bollas (2000), após a Segunda Guerra Mundial a psicanálise demonstra encantamento pela categoria diagnóstica "borderline", em detrimento da categoria "histeria". Segundo o autor (BOLLAS, 2000, p. 214):

O próprio fato de a psicanálise, encantada com as categorias psiquiátricas após a Segunda Guerra, ter desejado "estados mentais primitivos" sob a forma borderline, significou que os histéricos iriam sempre satisfazer esse desejo, especialmente por ele prometer progenitura a partir da cena primária psicótica. Cada analista, que se engajou nestes novos intercursos, sentiu que estava em uma nova fronteira, espiando uma nova entidade psíquica, prestes a ser escrita e nomeada. $\mathrm{O}$ fato de a psicanálise nos hospitais ter gradualmente expurgado a histeria de sua lista significou que ela teria de reaparecer sob outras formas.

A partir dessa consideração, constata-se uma espécie de risco de englobamento da histeria pelo conceito de fronteiriço, atualmente. Bollas (2000) contribui de maneira fértil para o reconhecimento dessas duas referências, pois se baseia em critério transferencial para conceber esses diagnósticos, assim como nos conceitos de regressão benigna e maligna de Balint (1993). Aponta a marca predominante de alguns pacientes histéricos, que abandonam níveis mais altos de funcionamento das regressões naturais decorrentes da relação transferencial, característica considerada benigna.

A marca central da histeria benigna, para Bollas (2000), reside na preservação de alguma tendência à independência relacionada aos processos de regressão. Mesmo nos casos de importante dependência, experiências do Self profundas e dolorosas, esse grupo caminha para a integração e autonomia. Portanto, essa característica constitui uma referência para a localização do quadro de histeria benigna. Por outro lado, há pacientes que se retiram bruscamente de níveis mais altos de funcionamento, e transferencialmente requerem do analista reparações de falhas ambientais brutais e cuidado. Nesses casos, o autor compreende a qualidade da regressão como maligna, por não visar, ao cabo, a retomada da tendência à independência como produto do processo terapêutico. 
Portanto, no caso da histeria maligna, Bollas (2000) reconhece a busca por delegar o Self ao outro, no caso o analista, com o intuito de coagi-lo a fim de obter um cuidado incondicional. Nesse sentido, o paciente espera que o analista ofereça um cuidado total, que esteja ali para atender toda e qualquer demanda e pelo tempo que for necessário. A terminologia "maligna" é atribuída pelo autor devido ao fato de não haver a intenção inconsciente de uma condução do Self à independência, mas justamente o oposto. Assim, o processo terapêutico e a transferência são experienciados como uma promessa, dívida a ser paga pelos "monstros do ambiente", objetos tóxicos que predominaram no ambiente inicial desses casos. Dessa forma, a promessa de uma reparação das falhas e maus tratos domina a cena transferencial, com tons de direito e exigência, pois esse sujeito permanece à espera de um objeto bom capaz de promover uma reparação coletiva.

Para Bollas (2000), na histeria o Self do paciente é apresentado como um evento, ou seja, predomina a fantasia de que somente sendo contundente ao imprimir suas dores, em forma de coação, ele será considerado. Nessa perspectiva, o outro deverá sentir suas dores, ser capturado e sofrer, de modo a "acreditar que, qualquer que ele seja, o futuro está nas mãos do destino" (BOLLAS, 2000, p. 191). O histérico maligno, portanto, na esperança de comunicação dessas necessidades pungentes, marcará o processo com a predominância de atuações, dentro ou fora do setting terapêutico. Esse expediente visa, do seu ponto de vista, a coação do analista no sentido de ser tomado como testemunha passiva do universo de eventos aterrorizantes presentes em sua subjetividade. Para o autor, este tipo de paciente lança e imputa maciçamente ao outro as identificações projetivas parentais que lhe foram impostas pelos pais em momentos prematuros do desenvolvimento do Self, como esperança de comunicação. A brutalidade de tal contato parental passa a operar como substituto do contato sensual com o bebê, de forma que a identificação projetiva assume o estatuto de única marca de toque e contato, espécie de referência básica da presença do outro.

Bollas (2000) leva em consideração o percurso transgeracional ao ponderar que a mãe é a figura intermediária das identificações projetivas evacuativas recebidas pelos pais dela, os avós do bebê. Assim, ela transmitirá projeções violentas de seus objetos internos ao filho, que será possuído por eles. Para Bollas (2000), é nessa dinâmica que reside a origem do fenômeno da possessão histérica por espíritos e entidades invasoras. 
O histérico maligno vive uma experiência de confusão por uma mistura de outros que carrega em sua vida psíquica, objetos incongruentes, que povoam seu Self de maneira dissonante e imperativa. Nessas subjetividades há uma espécie de susto relacionado com o conteúdo heterogêneo e antagônico da vida psíquica, um tipo de preâmbulo das dissociações do Self. Bollas (2000) menciona que essa condição parece ser "testemunho psíquico" dos objetos primários projetados, pois existem diversos residentes no interior do Self.

Para o autor (BOLLAS, 2000), frequentemente o histérico maligno tenta persuadir o analista de que os produtos expostos nas sessões não são dele, devido ao barulho objetal das diversas vozes que compõem essa condição. Bollas (2000) aponta que esse tipo de paciente tem sido tomado sob a noção de personalidade múltipla, por conta de alguns terapeutas aceitarem conversar com entidades diferentes que habitam o paciente e compreenderem que não há um Self presente nos momentos de atuação histérica. A marca principal desse estado emocional, em termos de discriminação do fronteiriço, se baseia na condição de um superpovoamento interno, próprio da histeria. Tal característica separa radicalmente a histeria do fronteirço, que é marcado por um esvaziamento objetal, despovoamento interno e empobrecimento da fantasia. Contudo, o autor faz a ressalva de que o histérico maligno é um primo psíquico do fronteiriço, embora o segundo quadro seja mais grave. Adverte que, de qualquer maneira, o histérico maligno pode confundir-se com o fronteiriço em um primeiro momento, porém sua marca é a capacidade de invadir o outro e "atuar o caráter dele".

Uma referência central para a diferenciação desses quadros reside na constituição da sexualidade. No caso da histeria maligna, a genitália e os impulsos sexuais são sentidos, predominantemente, como desestruturantes, violentos e ameaçadores. Segundo Bollas (2000), há uma dissociação extrema que transfere conteúdos internos para o externo de maneira performática. Nessa conturbada composição da vida erótica, tanto o histérico maligno como o benigno transformam a si em um evento, performance observada por um Ego focalizado no próprio prazer. Contudo, a auto-observação é mais proeminente e bizarra no histérico maligno. Segundo o autor, há uma dissociação no Self de bebê, que não reflete a imagem de uma pessoa integrada, mas um conjunto de objetos internos camuflados e dissimulados como Self. Ocorre, portanto, uma importante confusão de identidade devido a essa superpopulação de objetos e identificações divergentes. 
Histéricos malignos sentem o Self como caos e percebem a escolha de objetos como imposição da atração pulsional e não como produto do Self integral do outro. Portanto, nesses casos, há uma perda de qualidade da referência relacional, nos quais predominam os veículos da pulsão.

O reconhecimento dos limites entre os quadros fronteiriços e a histeria, a partir da contribuição de Green (2000), consiste no esforço de estabelecimento de contornos conceituais que permitam elucidar as peculiaridades de cada um deles. Para Green (2000), a relação entre estes quadros psicopatológicos necessita do reconhecimento de aspectos clínicos situados para além da neurose, em especial as depressões e psicoses. $O$ autor faz uma ressalva essencial, como referência diagnóstica básica, ao enfatizar que a definição de um quadro clínico nunca deve ser baseada predominantemente nos sintomas. Nesse sentido, frisa que o estabelecimento de um quadro conceitual necessita comportar a polissemia e as diversas expressões psicopatológicas, além de permitir a indicação de aspectos estruturais que fazem tais casos se manifestarem de uma forma em detrimento de outra.

Com essa contextualização, necessária devido às imprecisões comumente observadas no campo da saúde mental sobre o fronteiriço, torna-se claro que a histeria se localiza no terreno da neurose e difere essencialmente nos aspectos ligados ao amor e à sexualidade, terreno determinado predominantemente pelos caminhos e descaminhos do desejo, das identificações e da escolha de objeto. De acordo com Castello Branco (2004), a histeria se constitui justamente nesse registro psicopatológico, na dimensão da fantasia e da vida emocional, no uso do corpo e na relação com ele, assim como, principalmente, na sensibilidade depressiva. No campo do sofrimento fronteiriço, comparecem pacientes constituídos a partir de organização não neurótica (MINERBO, 2009) e desprovidos da referência principal do conflito psíquico como eixo organizador, assim como de elementos relacionados ao amor e à sexualidade. Nesses pacientes, a vida sexual e amorosa ocupa lugar secundário em detrimento de componentes destrutivos e narcísicos.

Uma diferença fundamental é o fato de que na histeria sempre há um outro constituído e a composição de uma cena que o inclui. O outro comparece como referência de dissociações, esvaziamentos e outros desdobramentos sempre incluídos no campo da transferência. Já o fronteiriço permanece às voltas com o esforço de preservação da 
integridade mínima de um Self instável que ameaça ruir, condição em que o outro e os objetos consistem em elementos vagos, distantes, porém vitais. Embora também presente no paciente histérico, a tendência à fragmentação do Ego se dá de maneira muito mais importante e extrema no fronteiriço, manifestada na disposição à despersonalização, à depressão e à persecutoriedade, fenômenos que conduzem esses pacientes a regressões extremas na direção da dependência (BOLLAS, 2006).

Outro ponto de diferenciação importante entre essas categorias diz respeito ao lugar central da angústia de castração e de penetração, no caso da neurose. Castello Branco (2004), ao abordar tal discriminação, aponta a destrutividade como centro do drama borderline. Assinala que o fronteiriço se constitui a partir do pavor de desmoronamento e de invasão por um objeto mau, perigoso e agressivo. Relacionadas às angústias de separação e de intrusão, essas ameaças revelam o medo de uma catástrofe que predomina na vida psíquica dessas pessoas e as conduz a meios projetivos e atuações disruptivas como forma de defesa e alívio. Assim, os dramas característicos dos pacientes fronteiriços, vinculados à integridade do Self, à vida e à morte, a sentir-se vivo e real, diferenciam-se fundamentalmente das questões relacionada à sexualidade, aos conflitos e ao percurso edípico, presentes nas neuroses, na perversão e nos pacientes histéricos. No fronteiriço, predomina o aniquilamento, que impede uma estruturação baseada na angústia de castração, por se tratar de constituições pré-edípicas (BOLLAS, 2006; FIGUEIREDO, 2006; GREEN 1990). Dessa forma, a aparição de estados erotizados e de diversas formas de contato sexual não indica necessariamente movimentos determinados pelo desejo ou mediados por fantasias. Constitui, sim, uma busca por intensidades, pela experiência de estar vivo, e um teste de realidade (FIGUEIREDO, 2006), mais do que relações eróticas genitais.

Contudo, as tentativas de manutenção e constatação de integridade do Self não indicam estabelecimento de franca psicose. Sobre a discriminação entre psicose e o fronteiriço, Figueiredo (2006) aponta elementos diferenciais com base em Kernberg. Considera que o fronteiriço é capaz de fazer o teste de realidade nos moldes que Freud (1911) descreveu no início do século passado. Já no caso da psicose, há prejuízo e perda de contato com a realidade predominante na vida do sujeito. Todavia, a prova de realidade realizada pelo fronteiriço não promove amadurecimento emocional, tampouco a capacidade de aprender com a experiência. Pelo contrário, o contato leva o paciente a 
experiências de grande perturbação, que culminam em destinos de compulsão à repetição. Nesse terreno fronteiriço, ocorre o drástico embaçamento dos limites entre fantasia e realidade, assim como mundo interno e externo, referências que não se estabeleceram suficientemente. Assim, os contatos com a realidade e os períodos de lucidez são acompanhados de profunda perturbação, disrupção, violência e depressão.

A partir do trabalho de diversos autores sobre o fronteiriço (LONDOÑO PAREDES, 2015; HOFFMANN; COSTA, 2014; JORDÃO; RAMIRES 2010; SALOMONE, 2009; FIGUEIREDO, 2006; LUNBECK, 2006; BRADLEY; WESTEN, 2005), assim como das obras de Green (2000), Bergeret (1998) e Kernberg (1975), torna-se possível agrupar características predominantes do fronteiriço para circunscrever o conceito. Destacam-se as oscilações radicais da vida pulsional, na organização do Self e nas relações objetais. Variações bruscas do humor comparecem como marcante propensão à turbulência emocional, grave impulsividade, violência, incontinência e pressão afetivas. Embora os aspectos psicóticos sejam marcantes, não chegam a constituir plenamente uma psicose, fato que permite vidas razoavelmente organizadas em determinadas áreas. Os pacientes apresentam dissociações e variações da organização do Self que vão da grandiosidade ao enfraquecimento e à proximidade de um estado de inexistência. Especialmente com foco nas relações objetais, sentem que o objeto ora é percebido como presença excessiva, ora como ausência insuportável; ora com estatura inalcançável, ora rebaixado e degradado. Transições bruscas entre um objeto muito bom e um objeto muito mau são frequentes, tendo a versão má do objeto, geralmente, seus poderes supervalorizados. Trata-se de uma condição de ambivalência, simultaneidade contraditória, vazio, invasão, ausência objetal, diluição da identidade e dependência.

A partir dessa breve delimitação psicopatológica e psicanalítica, o conceito será discutido - com a ressalva de que a imprecisão que sua história carrega é insolúvel -, assim como suas possíveis relações com o fenômeno da adicção. 


\subsection{SOBRE O CONCEITO PSICANALÍTICO DE ADICÇÃO}

O tema das adicções será abordado devido a sua amplitude e capacidade de aplicação a diversas condições emocionais, a diferentes estruturas diagnósticas, assim como a diferentes objetos. Especialmente, esse conceito será lançado a fim de compreender um possível componente adictivo, próprio de algumas condições fronteiriças. Assim, a breve apresentação do conceito de adicção se faz importante.

A adicção, em especial às drogas, tornou-se alvo de grande interesse atualmente, em diversos contextos, por conta do vulto que tem ganhado como acontecimento clínico e social. Apesar de ser um tema candente nos dias de hoje, trata-se de um assunto que acompanhou o homem ao longo de sua história e interessou a psicanálise desde o início. Freud $(1930,1924)$ se relacionou com o tema a partir da preocupação clínica e cultural, tendo em vista inclusive os descaminhos da utilização de cocaína como forma de tratamento. Foi um dos pioneiros na descoberta do potencial medicinal da cocaína aplicada a diversas doenças orgânicas no final do século XIX. Além disso, tinha a intenção de conseguir, com a cocaína e seu efeito estimulante, um tratamento para histeria, melancolia e neurastenia (GURFINKEL, 2011; CESAROTTO, 1989).

Freud relaciona uso compulsivo de álcool aos estados maníacos em 1917 e, em 1930, compreende o uso de substâncias como forma de alívio do mal-estar inerente à vida na cultura. Outros psicanalistas precursores da psicanálise também se ativeram ao tema. Abraham (1908/2003), por exemplo, entende a origem da compulsão às drogas como produto da avidez oral. Relaciona o prazer proporcionado por drogas como morfina e álcool ao prazer obtido através de alimentos por pacientes compulsivos. Assim, focaliza o prazer da ingestão como elemento central da toxicomania, mais do que o efeito psicoativo produzido por uma substância.

Radó (1933/1997), em 1933, destaca a toxicomania como patologia narcísica devido à incapacidade desses pacientes de suportar frustrações e ao fato de que estas facilmente os levam à depressão. Para o autor, adesão compulsiva tem relação com o princípio do prazer, por conta do alívio e da euforia transitórios, que levam o paciente a repetir o ciclo de busca constantemente. Segundo Rádo, um elemento importante da toxicomania são as alterações de humor, que variam de estados maníacos à depressão. 
Essa dinâmica envolve traços tanto maníacos como depressivos, afirma o autor, que aponta o alívio do sofrimento pela ação.

Muitos precursores da psicanálise vinculam a adiçcão aos estados maníacodepressivos (SIMMEL, 1929; GLOVER, 1932; KNIGHT, 1937, ROSENFELD, 1968). Rosenfeld (1968), especialmente, atribui a origem da busca pela droga à intenção de atingir artificialmente estados maníacos, em consequência de um Ego incapaz de suportar a depressão. Para o autor, os estados maníacos almejados na dinâmica da adiçcão levam o sujeito à idealização e à identificação com o objeto ideal, ao controle onipotente dos objetos e à negação da angústia por meio da alucinação. Para ele, a adiçcão deriva da incapacidade do paciente dependente de suportar o sofrimento, o que culmina na clivagem do Ego e dos objetos internos.

Uma importante contribuição foi ofertada por Fenichel (1945/1997) ao descrever impulsos patológicos compreendidos como neuroses impulsivas. Ele refere a impossibilidade de resistir ao impulso na direção de um objeto como marca central dessa condição. A organização psíquica em torno dessa dificuldade, por sua vez, significa que alguns pacientes não são capazes de tolerar tensões e vivem a experiência de urgência imediata da satisfação. $\mathrm{O}$ autor relaciona as neuroses impulsivas às fixações orais e, portanto, às perversões. Contudo, utiliza o exemplo do bebê à espera do leite materno, focalizando o aspecto das necessidades narcísicas e de proteção em primeiro plano, em detrimento do aspecto econômico. Aponta que esses pacientes temem o perigo de sentir impulsos pela ameaça à permanência do objeto-seio, ou seja, há um drama circunscrito na experiência de necessidade do objeto versus sua permanência. Trata-se de uma condição que imputa ao objeto a responsabilidade de alívio do sofrimento e ao mesmo tempo desperta no paciente o medo e a culpa por sua destruição. Acerca da neurose impulsiva como adicção às drogas, Fenichel descreve a busca por segurança e manutenção de uma integridade narcísica através desse expediente. O anseio pela gratificação é acompanhada pela desconsideração do outro, ou do objeto, seja qual for, do qual, paradoxalmente, o paciente depende, nos moldes da obtenção de alimento e calor.

Fenichel $(1945,1997)$ também inclui as adicções a objetos diversos à droga no rol das neuroses impulsivas, como a adiçcão à comida e a hobbies como a leitura, bem como, sobretudo, a adiçcão ao amor. Dessa forma, a adiçcão como neurose impulsiva 
abarca diversa gama de objetos, desde uma substância até o amor, um objeto-outro, próprio do drama ora pesquisado acerca do paciente fronteiriço.

Portanto, o conceito de adicção será utilizado nesta pesquisa para abordar a qualidade de dependência emocional marcadamente presente no paciente fronteiriço. Tal conceito psicanalítico foi adotado por assinalar diferenciação fundamental da perspectiva biológica das dependências, seja a uma droga, seja a outro objeto, pois se baseia em concepção psicodinâmica de dramas essencialmente relacionais. Nesse sentido, a noção de adiçcão se contrapõe ao olhar biológico por conceber um corpo com história subjetiva.

"Adicção", "vício", "compulsão", "dependência" consistem em termos comumente relacionados ao uso prejudicial de substâncias. Contudo, todas essas palavras podem designar formas de relação com objetos variados, partícipes da vida humana. Dessa forma, o presente estudo versará sobre a adiçcão como qualidade compulsiva de relacionamento fundada em uma subjetividade e não em um organismo. Além disso, abordará a adicção ao outro, objeto que não é o mais usual na cultura.

Para Guerreschi (2007), o termo "dependência" diz respeito à condição de um organismo que necessita física e quimicamente de determinado elemento para funcionar, e por conta disso o procura. Portanto, segundo o autor, essa é uma terminologia utilizada basicamente para designar o consumo compulsivo de substâncias por um organismo, com ênfase em descompensações e determinações neurobiológicas. No caso da adiçcão como componente da dinâmica do fronteiriço, será adotado um ponto de vista que não compreende o corpo apenas como um organismo, pois esse conjunto de células, circuitos neuronais e secreções de neurotransmissores necessita de um outro para se tornar unidade, a partir do ponto de vista do sujeito. No caminho do desenvolvimento psíquico e emocional do ser humano, o bebê depende desse outro para transformar um corpo-coisa em um corpo prenhe de sentido de unidade, portador de identidade humana. É a partir da relação com o ambiente, nos cuidados e na sustentação que este oferece, que o orgânico passa a um corpo vívido e humanizado (WINNICOTT, 1990).

A adicção, portanto, faz referência a uma condição geral de dependência psicológica que impele o indivíduo à procura de determinado objeto, sem o qual a vida se torna sem sentido. A amplitude desse termo permite sua aplicação a diversos objetos, para além de álcool e outras drogas. É possível conceber a adicção a jogos, comida, se- 
xo, esportes, trabalho, internet, compras, celular, entre outros objetos atualmente tomados de forma compulsiva (GUERRESCHI, 2007). Outra diferenciação importante diz respeito à toxicomania, termo bastante encontrado na literatura psicanalítica. Segundo Gurfinkel (2011), tal palavra consiste em uma modalidade específica de adiçcão às drogas, ou seja, há uma exclusividade relacionada ao objeto de adicção droga.

Um ponto relevante das diversas terminologias consiste na conotação negativa que carregam, seja no mundo acadêmico, seja no senso comum. Toxicofilia, toxicotimia, uso nocivo, abuso, vício denotam sentidos primariamente negativos, patológicos e degradantes a respeito da ligação entre usuário e droga, nesses casos. Por exemplo, "toxicomania", que deriva do francês toxicomanie, comporta significado de loucura ou desejo de envenenar-se, ponto de vista que destaca a busca pela droga como meio de autodestruição. De forma oposta, a palavra "adiçcão", que deriva do inglês addiction, denota escravidão a um objeto (MCDOUGALL, 1992).

A etimologia do termo "adiçcão" está ligada à palavra latina addictus, que significa estar submetido a um credor por uma dívida, escravizado por conta disso. Segundo Gurfinkel (2011), a origem do termo tem relação com uma lenda romana em que um homem endividado vendeu sua alma para o diabo e ficou prisioneiro dele, aspecto que marca a condição de refém de algo ou alguém que, paradoxalmente, salva e tortura. A partir dessas imagens relacionadas ao termo "adicção", é possível apreender uma inversão: o indivíduo que, movido por seu desejo, desfrutava de um objeto livremente, tornase objeto de seu objeto, ou melhor, estabelece-se uma relação de submissão a ele.

A escolha do conceito de adicção para abordagem do objeto do presente estudo se deve à referência à luta desigual do sujeito contra aspectos de si, dores remediadas através de expedientes exógenos, como forma única de alívio do sofrimento emocional e atribuição de sentido para a vida. Um ponto de partida fundamental para este estudo baseia-se na compreensão de McDougall (1992) de que, nas adicções, não há busca primária por destruir-se ou escravizar-se. Ao invés disso, o objeto de adicção é investido de aura mágica, qualidades positivas devido à esperança de afastar sofrimentos emocionais e condições psíquicas intensamente dolorosas. Assim, tornar-se escravo e degradarse consistem em consequências negativas secundárias de um movimento inicialmente positivo, de alívio e automedicação. 
De qualquer maneira, essas diversas terminologias dizem respeito a um uso excessivo, impulsivo, compulsivo e desenfreado de determinado objeto. Designam formas de relação que se afastam do uso criativo ou recreativo, no caso das drogas, por exemplo, e caminham para o lado oposto de experiências socialmente compartilhadas, mediadas por significados culturais ou carregadas de sentido para o sujeito. A partir do conceito de adicção, destacam-se a vivência de impossibilidade de interrupção da busca e uso de determinado elemento, a rigidez dos circuitos envolvidos nessa dinâmica, a priorização e exclusividade do objeto de adicção em relação ao horizonte de possibilidades que a vida e a cultura dispõem. Nesse sentido, ao abordar a toxicomania, Gurfinkel (1995, p. 39) destaca:

O que se passa com o sujeito que "não pode mais parar", que se sente enganado pelo objeto em que buscou prazer e pelo qual agora se sente escravizado? O poder sinistro de escravização está no sujeito, no objeto, ou em algum "espaço intermediário" entre os dois? Ora, se fosse apenas o poder mágico da droga o responsável por isto ela provocaria em todos igualmente a escravidão, o que não é absolutamente verdadeiro. Existiria então uma diferença qualitativa entre o usuário e o dependente? Qual seria? Na prática, encontramos ainda uma grande série de "usos intermediários", o que torna de certa forma insatisfatória e reducionista a polaridade usuário-dependente.

A reflexão desse autor frisa a necessidade de focalizar a atenção sobre o sujeito que "consome" o objeto, em vez de sobrevalorizar o objeto de adicção como elemento causador de uma complexa relação. No caso das drogas, como emblema destacado da adicção na cultura, é frequente a observação de uma importante atribuição de valor à substância em detrimento de quem a usa. Assim, a demonização da bebida, do "pó", do jogo, do sexo, da comida, das compras ou de outras possibilidades de um vínculo adictivo ganha protagonismo e deixa o agente - a pessoa e sua dimensão subjetiva - no lugar de coadjuvante, vítima ou transgressor. Trata-se de tendência construída historicamente (ESCOHOTADO, 1996), um olhar que tende a mirar apenas em um dos polos de uma relação necessariamente constituída de duas partes.

Um aspecto fundamental a ser considerado se expressa na marca comum dos processos de adiçcão aos diversos objetos possíveis, a coisificação (GURFINKEL, 1995) de elementos humanos e sua redução a coisas inumanas, concretas e despersonifi- 
cadas. No caso das toxicomanias, que consiste em adiçcão ao objeto-droga, há um investimento radical e priorização de uma substância em relação aos demais objetos da vida, de modo que esse pó ou pedra mágicos (des)organizam as rotinas, contatos e espaços do adicto. O exemplo da adiçcão às drogas deixa claro tal processo de degradação do traço humano e permite o reconhecimento de amigos, contatos, colegas de uso, lugares e demais elementos envolvidos como meros coadjuvantes do enredo adictivo. $\mathrm{O}$ holofote, nesses casos, sempre estará focalizado no objeto-coisa, colorido com tons mágicos, sagrados e carregados de poder, marcadamente elevados em termos de importância e ascendência. Esse lugar totêmico atribuído a um objeto é acompanhado da desobjetalização (GREEN, 1988c) do humano, caminho marcado por deterioração da qualidade de relação objetal.

Tal elevação radical do objeto transpõe seu estatuto para um nível muito mais relevante do que algo que possa ser procurado e utilizado em função de um desejo. Mais do que isso, nas adicções aquilo que estava ou deveria estar no lugar de um objeto de desejo assume a qualidade dramática de necessidade, como a fome e a sede. Segundo McDougall (1997), o objeto de adicção assume a grandeza daquilo que é necessário para a sobrevivência e, dessa forma, sua procura não pode ser adiada, a liberdade de escolha deixa de ser uma possibilidade, assim a busca imperativa e inadiável se instala como meio de vida, uma escravidão. Nessa inversão própria das adicções, portanto, o objeto se torna fonte exclusiva e profundamente necessária de alívio e sustentação, quando originalmente não haveria motivo algum para o sujeito buscá-lo como forma de sobrevivência.

Nesse modo específico de relação, o conceito de adicção torna-se caro devido à independência relacionada ao objeto. Este pode variar amplamente, do mais usual e corriqueiro, como a droga, ao mais singular. Destaca-se, no caso desta pesquisa, o objetooutro, uma pessoa tomada nos moldes de uma droga. Tal terminologia, aplicada ao objeto deste trabalho, revela uma visão de homem, assim como do que é patologia ou patológico. Com isso, o sentido de um drama humano relacionado à dependência do outro será considerado, acima de qualquer conotação baseada em normalidade e possíveis desvios, como componente do sofrimento fronteiriço (CRUZ; TARDIVO, 2013). 


\subsection{PANORAMA PSICANALÍTICO: DOS AUTORES CLÁSSICOS AOS CONTEMPORÂNEOS}

Esse vasto campo se desdobrou em caminhos distintos e ainda mantém a questão do fronteiriço como um desafio para a psicanálise contemporânea, tanto do ponto de vista teórico-conceitual, como do clínico. Dentre os principais expoentes psicanalíticos que se ocuparam do tema, destacam-se Donald W. Winnicott, André Green, Joyce McDougall, Otto Kernberg e Jean Bergeret, que desenvolveram conceitualizações distintas e originais.

\subsubsection{Donald Winnicott}

Winnicott, em sua obra, se debruçou de maneira original e fecunda tanto sobre a questão do fronteiriço, como das adicções. Trata-se de autor fundamental para a abordagem desses temas, que foram trabalhados clinicamente e teorizados a partir de uma nova abordagem frente à nosologia clássica, psiquiátrica ou psicanalítica (WINNICOTT, 1965/1983). Em seu olhar, o psicanalista é compreendido nos moldes de "um especialista em obtenção da história" (p. 121), situado a partir do interior da experiência clínica.

Assim, a atividade diagnóstica consiste em operação contínua que pode ser reformulada com o aprofundamento do processo, pois parte de um olhar não estruturalista para o humano, segundo o qual as psicopatologias não têm estatuto imutável. Segue uma breve amostra de sua postura frente à nosografia: "a contribuição mais importante da psicanálise para a psiquiatria e a classificação é a destruição da velha ideia de entidades mórbidas. O psicanalista praticante concordará que há uma gradação da normalidade, não apenas na psiconeurose, mas também na psicose" (p. 119). Ou seja, "uma histérica pode se revelar uma esquizofrênica subjacente, uma pessoa esquizoide pode vir a ser um membro sadio de um grupo familiar doente, um obsessivo pode se revelar um depressivo" (p. 121). Frente a esse olhar para a psicopatologia psicanalítica torna-se

importante apresentar as concepções do autor sobre o paciente fronteiriço e sobre a adicção, pois compõem importante referência epistemológica da presente pesquisa. 


\subsubsection{Winnicott e o fronteiriço}

A concepção winnicottiana sobre o paciente fronteiriço baseia-se essencialmente em um prisma ambiental e relacional (WINNICOTT, 1949, 1958, 1960, 1963a). Trata-se de uma constituição resultante de operações defensivas advindas do medo do colapso (WINNICOTT, 1963/1990) e de aniquilamento. Tal medo se refere a algo que já ocorreu, porém esse acontecimento não pôde ser vivido como experiência, basicamente porque não havia alguém constituído a partir de seu próprio ponto de vista. Para que uma experiência possa ser vivida como tal, é preciso que exista uma pessoa inteira, ou seja, um Self unitário. A experiência de invasão de Self não pôde ser vivida por ter ocorrido em momento primitivo de não discriminação Eu / não-Eu. Essa impossibilidade se dá quando os recursos psíquicos e emocionais não estão suficientemente desenvolvidos a ponto de conterem ou elaborarem as angústias advindas de acontecimentos radicais em ocasiões iniciais da constituição do Self.

Apesar dessa localização inicial de acontecimentos disruptivos, circunscrever o conceito de fronteiriço em Winnicott não é uma tarefa simples, pois o autor não ofereceu uma sistematização didática desta conceitualização em sua obra, na qual fez menção ao termo fronteiriço em algumas passagens (1949, 1960, 1963a). Independentemente de uma sistematização, trata-se de um autor fundamental para a abordagem do tema. Nas palavras de Green (1988, p. 74):

[...] é Winnicott $(1965,1971 a, 1971 b, 1975)$ que, especificamente, em minha opinião, é o analista do fronteiriço. Seu inimitável estilo e sua original conceituação não se prestam a uma fácil sumarização. A nitidez aparente de Winnicott é desnorteadora e, com frequência, se leem autores inspirados por suas contribuições, que não fazem jus à sutil e rica complexidade de suas ideias.

Em uma das breves menções à delimitação desse conceito, Winnicott (1969) define o termo "fronteiriço" como o tipo de caso no qual o núcleo ou centro do transtorno é psicótico, porém o paciente sustenta uma organização neurótica, ou transtorno psicossomático, quando a angústia psicótica ameaça surgir de forma bruta. Ou seja, compõe uma constituição baseada em sofrimento psicótico e a consequente iminência de desmoronamento do Self, ao mesmo tempo em que apresenta organização própria das 
psiconeuroses. Dessa forma, o tipo de angústia em jogo discrimina a psicose, fundada sobre a ameaça de aniquilamento, da neurose, baseada na angústia de castração. Assim, no caso fronteiriço, a sintomatologia pode parecer neurótica ou psicossomática, porém no centro predomina a angústia psicótica básica.

Na obra winnicottiana (WINNICOTT, 1952, 1960, 1962, 1963a), o sofrimento psicótico ocupa lugar central e paradigmático, inclusive ao abordar o fronteiriço e a esquizoidia como possíveis variações clínicas. O autor se dedicou ao estudo do desenvolvimento emocional primitivo, dos meses iniciais da vida humana, momento crucial no qual podem ocorrer as falhas responsáveis pela constituição de quadros psicóticos. Essa condição, em suas diversas possibilidades de manifestação para o autor, como o autismo, o falso Self, a esquizofrenia latente e a esquizoidia, advém de falhas localizadas no período de dependência absoluta. O fronteiriço também compartilha tal origem, integrando o rol das patologias derivadas das falhas ambientais relacionadas à dependência absoluta, embora o autor não o inclua ali deliberadamente.

Winnicott $(1963,1963 b, 1969)$ apresenta significativo olhar para a compreensão psicanalítica sobre o fronteiriço, a partir do ilustre relato da análise de sua paciente Margareth Little (LITTLE, 1990). Evidencia-se, com sua narrativa, o cuidado dedicado por Winnicott a seus pacientes. Estados regressivos de fúria, agressividade, paranoia e confusão foram percorridos e sustentados pelo analista - em um episódio desse processo analítico, a paciente pôde contar com o auxílio de dois objetos transicionais, um lenço dado por Winnicott e um cachecol de lã azul. Tais intervenções em forma de holding indicam que a constituição de objetos e fenômenos transicionais tem fundamental importância nesses estados emocionais.

Uma importante diferenciação nessa apresentação conceitual consiste na delimitação entre a concepção de fronteiriço e esquizoide. São termos que comparecem em sua obra de maneira pouco sistematizada e emaranhada, por vezes sobrepostos ou de forma distinta. Fundamentalmente, em termos de diferenciação dos quadros, o esquizoide vive um importante entrave ao se relacionar com o mundo externo e habita a experiência de a vida interna e subjetiva ser muito mais significativa e real do que a vida compartilhada e objetiva. Em uma perspectiva etiológica, o sujeito esquizoide sofreu uma invasão muito grave da realidade externa no momento de dependência absoluta, promovendo uma reação que interrompe a experiência de continuidade de ser e, portanto, im- 
pede a expressão criativa e espontânea baseada na experiência de recepção de seu Self pelo ambiente. Essa reação defensiva gera retraimento e reclusão ao seu mundo interno.

O esquizoide, frente a uma precária conquista de integração do Self, vive angústias primitivas e não simbolizadas que rondam sua vida emocional, sob a ameaça de (re)viver tais agonias impensáveis. Trata-se de uma formação baseada no isolamento defensivo do Self, a fim de impedir sua aniquilação. Isso porque, dada a precária integração do Self nesses pacientes, a realidade externa se torna uma grande ameaça. Dessa reação frente ao ambiente, surge uma pessoa que pode não se sentir viva ou real, incapaz de ter uma presença ou contato autêntico com o mundo devido a tamanho isolamento de aspectos próprios que não ganham comunicação (DIAS, 2003).

Winnicott $(1962,1952,1959)$ compreende que tal estado de esquizoidia se relaciona com o falso Self como meio defensivo de contato com o mundo, assim como no caso da psicose propriamente. Nesse estado comparecem predominantemente as angústias impensáveis relacionadas à integridade do ser, como cair para sempre, dissociação entre psique e soma, desintegração, à frente da ameaça de perda do outro. Contudo, o temor do isolamento também está presente no esquizoide, que pode buscar regressivamente experiências integradoras em seu percurso. É possível depreender das teorizações do autor, neste campo de intersecção e aparente indiscriminação entre as patologias em questão, que o fronteiriço lança mão de um falso Self como defesa independentemente de ter vivido uma reação de isolamento.

Segundo Nafah (2010), o conceito de fronteiriço é mais amplo que de esquizoidia em Winnicott. O borderline não está circunscrito a uma configuração de retraimento como recurso defensivo contra a psicose, condição que o torna mais abrangente. Segundo esse comentador do trabalho de Winnicott, o fronteiriço é um estado mais aproximado da esquizofrenia latente. Isso porque o estado psicótico está na iminência de ruptura, porém contido por sintomatologia neurótica e organizado por um funcionamento adaptativo oriundo de um falso Self cuidador.

O falso Self, conceito de fundamental importância na obra winnicottiana, corresponde a um novo olhar sobre os estados psicóticos em relação às teorias precedentes em psicanálise. Winnicott (1965/1989) concebe tal formação como dissociação na mente com extensões variáreis, que pode ir da normalidade até a esquizofrenia. Em casos patológicos, o falso Self, gerado como reação às falhas ambientais, surge como ativida- 
de mental separada da experiência, de modo que a mente e o intelecto dissociados se responsabilizam pelo cuidado do psicossoma e do verdadeiro Self. Em outras palavras, o falso Self consiste em distorção defensiva com a finalidade de proteger esse núcleo verdadeiro (WINNICOTT, 1963/1983), pois, na normalidade, tal cuidado é promovido pelo ambiente, que em condições suficientemente boas permite a integração e a expressão minimamente autênticas. Fundamentalmente, trata-se de estado patológico de submissão, no qual o indivíduo tenta se adaptar ao ambiente - e não o oposto, que é condição para o desenvolvimento emocional saudável.

A submissão e adaptação à realidade externa fazem com que a vida e o mundo sejam percebidos de forma superficial, artificial e vazia. Trata-se de adesão maciça à realidade externa, com importante perda de contato com o que é próprio do mundo subjetivo. Assim constituem-se pessoas que não conseguem se situar a partir de identidades sentidas como verdadeiras. Não logram imprimir sua presença de forma criativa no mundo e padecem de sentimentos de desesperança, tédio e irrealidade. Segundo Win$\operatorname{nicott}(1990$, p. 129):

[...] quando há um certo grau de fracasso na adaptação, ou uma adaptação caótica, o bebê desenvolve dois tipos de relacionamento. Um tipo consiste num relacionamento secreto e silencioso com um mundo interno essencialmente pessoal e íntimo de fenômenos subjetivos, e é exclusivamente este relacionamento que parece real. O outro é exercido a partir de um si-mesmo-falso e se estabelece para com um ambiente obscuramente percebido como exterior ou implantado.

Dessa forma, o fronteiriço se constitui como patologia derivada de falhas ambientais ocorridas em momento de dependência absoluta, que levam o sujeito à impossibilidade de constituição de contornos de um Self suficientemente integrado e capaz de promover a apreensão do outro como elemento não-Eu, separado de si. Sobre a origem dessa condição, Winnicott (1969) aponta para a problemática da constituição do objeto subjetivo como momento crucial da formação psicopatológica borderline, passo crucial para o amadurecimento emocional, em que se dá a discriminação Eu / não-Eu do primeiro objeto distinto do bebê. Portanto, a primeira concepção do objeto é subjetiva. Em um período do desenvolvimento, os contornos do Self ainda se encontram instáveis e, por isso, o bebê pode apenas se relacionar, mas não fazer uso desse objeto. Para que essa aquisição fundamental ocorra, as experiências de ilusão e desilusão devem cami- 
nhar de forma que haja o reconhecimento da existência desse objeto como elemento fora de seu controle onipotente e, assim, possa ser objetivamente percebido como realidade externa.

Winnicott (1975) ilustra, com duas situações, a diferença entre a capacidade de usar ou não uma relação no desenvolvimento inicial de uma pessoa. Na primeira situação, um bebê se relaciona com um seio que é objeto subjetivo ${ }^{5}$; na outra, outro bebê faz uso do seio como alteridade. Nas palavras do autor:

Em termos clínicos: dois bebês estão sendo amamentados ao seio. Um deles se alimenta do eu (self), visto que o seio e o bebê ainda não se tornaram (para o bebê) fenômenos separados. O outro se alimenta de uma fonte diferente-de-mim, ou de um objeto que pode receber um tratamento desdenhoso, sem efeito para o bebê, a menos que ocorra a retaliação. As mães, como os analistas, podem ser boas, ou não suficientemente boas; algumas podem fazer o bebê passar do relacionamento ao uso, ao passo que outras não o conseguem (WINNICOTT, 1975, p. 124).

No percurso que parte da relação com o objeto e chega a seu uso, ou seja, que parte da percepção subjetiva e chega à objetiva, o objeto deve ser destruído. É justamente pela sobrevivência do objeto a esse movimento de destruição que a experiência do mundo objetivo se instaura e há a possibilidade de uso, a partir do reconhecimento de seu estatuto de alteridade concreta e objetiva. Dessa forma, em tal movimento de destruição, que é movido pela agressividade primária, o objeto resiste e, no melhor cenário, sobrevive. Tal experiência abre caminho para o uso de um objeto constituído e para a configuração de limites Eu / não-Eu mais definidos. No fronteiriço, porém, essa capacidade de fazer uso dos objetos, reconhecidos como alteridade, não se consolidou plenamente devido ao colapso na constituição do objeto transicional. Trata-se de um impasse do caminho da transicionalidade, em que a experiência de discriminação dos limites do Self e do mundo não se consolidou. Nesse estado de contornos vacilantes, o estabelecimento de uma relação com um objeto reconhecido como objetivo, não-Eu, fica comprometido.

\footnotetext{
5 "O termo objeto subjetivo foi utilizado para descrever o primeiro objeto, o objeto ainda não repudiado como um fenômeno não-eu” (WINNICOTT, 1975, p. 114).
} 
Acerca da problemática dos fenômenos transicionais, conceito criado por Winnicott (1975), Green (1988) aponta que o paciente borderline é caracterizado por uma dificuldade de manifestar fenômenos transicionais. Embora sejam capazes de criar objetos ou fenômenos transicionais precários e parciais, esses pacientes criam sintomas para preencher e ocupar a função dos fenômenos transicionais, ou seja, estes não assumem para eles o valor funcional que têm para outras pessoas. A droga, o outro coisificado ou qualquer arremedo de objeto pode ser tomado como uma esperança de constituição de tal objeto intermediário, que não cumpre sua finalidade e, por isso, não pode ser abandonado.

A transicionalidade consiste na ampliação do conceito de objeto transicional criado por Winnicott (1975). Inaugura a terceira área da experiência humana, que não é totalmente subjetiva nem objetiva, na qual ocorre o brincar como posição existencial. É da construção desse terceiro espaço que a capacidade de criação nasce como uma transição que pode derivar para as experiências culturais, religiosas, assim como a perspectiva de uma vivência autêntica e ao mesmo tempo compartilhada.

Através desse delicado processo de separação e instauração da região intermediária, falhas ambientais importantes protagonizadas tanto pela mãe intrusiva como pela mãe que abandona impedem a construção desse espaço potencial. A intrusão pode impedir a criança de ter experiências por sufocá-la; assim como o abandono impossibilita o bebê, por insuficiência de holding, de criar recursos para suportar o afastamento ou usar $^{6}$ objetos como recursos provisórios. Sobre as vicissitudes de tais falhas, Paulina Kernberg (1983), citada por Outeiral (1993, p. 71), acrescenta:

Não é surpreendente que crianças borderline que não desenvolveram um sentido positivo de self em relação a um objeto positivo (no contexto de uma experiência de conforto e prazer com a mãe) não adotem um objeto transicional na fase dos oito aos vinte e quatro meses, ou um de qualidade apropriada, isto é, um objeto experimentado na gestalt da experiência materna (como a ponta do lençol, fralda ou brinquedo macio). Pelo contrário, estas crianças tendem a continuar "penduradas" na sua mãe, procurando experiências simbióticas positivas ou reabastecimentos positivos. Tendem também a representar suas relações com "a mãe má da separação", vinculando-se a objetos inanimados, como uma criança que tinha como objeto transicional um tele-

\footnotetext{
${ }^{6} \mathrm{O}$ termo "uso de objeto" em Winnicott significa criar e encontrar. Só pode ser usado aquilo que foi criado e encontrado pelo bebê.
} 
fone, que levava consigo onde quer que fosse. Além disso, os objetos transicionais das crianças borderline reproduzem caracteristicamente as imagens do self ou imagens e ideias semelhantes ao companheiro imaginário, em contraste com os objetos transicionais que refletem uma interação mãe-filho positiva.

Tais falhas do ambiente podem produzir na criança a importante dificuldade de representar objetos internamente, prejuízo central do drama fronteiriço. Falhas como a contínua e demasiada ausência da mãe podem gerar incapacidade de sua representação essa figura se torna vaga internamente e se esmaece. Winnicott (1975) descreveu alguns estados patológicos derivados dos objetos e fenômenos transicionais. No caso do fronteiriço, no descaminho da construção do espaço transicional irrompe um vazio angustiante e a busca por ocupá-lo. Trata-se fundamentalmente do drama e da impossibilidade radical de perda e separação, no qual os fenômenos transicionais não puderam realizar o processo de permanência do objeto em sua ausência e a plena constituição dessa referência intermediária da experiência.

Eis um aspecto central da articulação dos elementos ora estudados, pois o fronteiriço, assim como o adicto, sofrem pela perda de um objeto fundamental e se orientam com base em uma procura imperativa de reencontro, preenchimento e permanência através do agir. Tal ação nasce frente à inviabilidade de recursos gerados pelo espaço transicional, como a possibilidade de representação, simbolização, criação e o sonhar. Esse agir patológico é compreendido por Gurfinkel (2001) como um colapso do sonhar, condição de falência desse espaço potencial. Segundo o autor (2006), nessa situação, o sonho, a fantasia, a criação e o brincar cedem lugar para uma tendência de "coisificação" (GURFINKEL, 1995, 2001, 2008) da experiência subjetiva.

Um sonhar pleno, no qual a atividade onírica/transicional está preservada, carrega capacidade simbolizante, um sono preenchido por objetos oníricos, no qual a realidade externa comparece como parte da experiência onírica. Sono prenhe de vida psíquica, descrito por Gurfinkel (2001), capaz de dar suporte ao espaço potencial do criar e do viver. Segundo o autor, a existência de objetos não representa, no momento da criação do espaço transicional, um "alimento para o desejo", mas uma presença essencial para a sustentação desse espaço descrito por Winnicott (1975). A atividade onírica consiste em um momento fundante e inaugural na constituição da subjetividade, em que o acontecimento central não é da natureza do desejo, como proposto por Freud (1996/1900) na 
Interpretação dos sonhos, mas consiste no percurso da constituição de alguém, a partir do seu próprio ponto de vista. Trata-se da impossibilidade de sonhar no sentido concreto e metafórico, do brincar e do campo da poesia. Segundo Winnicott (1975, p. 151-152):

Existe em muitos um fracasso de confiança que restringe a capacidade lúdica, devido às limitações do espaço potencial; do mesmo modo, existe para muitos pobreza de brincadeiras e de vida cultural, porque, embora encontrem lugar para a erudição, houve um relativo fracasso por parte daqueles que, fazendo parte do mundo da criança, falharam em fornecer a ela elementos culturais nas fases apropriadas do desenvolvimento da personalidade.

Nesse sentido, a concepção de colapso do sonhar (GURFINKEL, 2001) se refere a uma condição de empobrecimento objetal e subjetivo, instaurada quando a capacidade onírica opera insuficientemente. Tamanha falha e impossibilidade da transicionalidade podem ser associadas com a "série branca" teorizada por Green (1988) em seu texto sobre o complexo da mãe morta. A angústia, o luto e a psicose brancos se referem aos espaços vazios no psiquismo ocasionados por perda objetal irreparável, cuja elaboração se tornou inviável - trata-se de uma representação da negatividade. O sono em branco apresentado por Gurfinkel (2001), sem sonhos devido a essas falhas, não constitui um setting para o sonhar, configura apenas um lugar vazio e de ausência no qual o espaço transicional deixa de existir.

O sonhar consiste em campo e função fundamentais para a operação do trabalho de luto positivo, condição prejudicada no fronteiriço, assim como no adicto. Nesses casos, não se trata somente de uma condição marcada pela perda do um objeto, mas fundamentalmente de algo anterior, a construção de um Eu capaz de simbolizar e suportar a experiência de perda. Isso não ocorre na concepção de colapso apresentada anteriormente, pois a perda não pode ser experimentada como privação ou destruição objetal, tampouco representada. Dessa forma, o trabalho de luto, de elaboração da perda e de separação não são viáveis, com a trágica consequência de a perda comprometer o sentimento de si e a continuidade do ser (WINNICOTT, 1975).

Essa brutal consequência sobre o campo da simbolização, do sonhar, do brincar e da continuidade de ser ocorre devido à instabilidade na relação inicial entre a mãe e seu bebê, uma conturbação na passagem da relação de indiferenciação para o momento 
em que o bebê vai paulatinamente adquirindo a capacidade de diferenciar dentro e fora, $\mathrm{Eu} /$ não-Eu. Dessa forma instala-se uma impossibilidade de preenchimento do vazio através de fenômenos e objetos transicionais (WINNICOTT, 1975).

Esse percurso, com falhas sucessivas, ocasiona uma incapacidade de trânsito pelos espaços psíquicos, pelos limites $\mathrm{Eu} /$ não-Eu, e a não instauração do "entre" prejudica a constituição do Self. Da ausência desse espaço intermediário decorrem a inconstância objetal e uma relação instável com o objeto, experimentado ora como excessivo e com presença insuportável, ora como ausente e distante demais, muito idealizado ou depreciado. Essa configuração da vida emocional se expressa com intensa turbulência do tipo tudo ou nada, com variações afetivas, atuações violentas em uma organização que pode gerar um Eu grandioso ou enfraquecido e diminuído (Kernberg, 1991).

É através da constituição e do uso do objeto transicional que o bebê será capaz de vivenciar a mãe como presente e ausente ao mesmo tempo. A aquisição dessa capacidade permite à criança a possibilidade de sustentar as ambivalências de uma relação com o outro. Essa importante falha na relação mãe-bebê e no caminho do amadurecimento emocional barra a transição da criança de um estado em que está indiferenciado para outro no qual a experiência de separação é possível. Tamanha dificuldade pode ser compreendida como origem do sofrimento borderline em se relacionar com o outro. Tal falha impede que representações, simbolizações e relações intersubjetivas sejam inauguradas. A incapacidade de trânsito de um estado indiferenciado para outro de discriminação inviabiliza a construção do espaço potencial, com a importante consequência da impossibilidade de simbolização. Tal inviabilidade de simbolização impede o Eu de se separar e diferenciar dos objetos, principalmente dos primários, levando esse indivíduo a se tornar escravo da angústia de perda ou de ser tomado pela presença excessiva do outro (WINNICOTT, 1975).

Winnicott (1982) indica que a perda do objeto primário, tal como a incapacidade de habitar o espaço intermediário da experiência humana, pode levar esse sujeito a viver uma descontinuidade de seu existir, que pode culminar na incapacidade de estar só. Surgem assim um vazio e o medo do abandono, que podem gerar uma relação de dependência anaclítica - e esta, por sua vez, pode sufocar e afastar os objetos. Tal dependência, uma adicção ao outro que sempre escapa, lança esse sujeito em uma relação 
desesperada de consumo, uma ligação brutal ao objeto, e o impede de ter uma experiência completa (WINNICOTT, 1975).

\subsubsection{Winnicott e as adicções}

Winnicott (1975) aborda as adicções, assim como os estados fronteiriços, de um ponto de vista fundamentalmente relacional. Focaliza um drama anterior à constituição de uma economia psíquica como origem da vinculação do sujeito aos diversos objetos possíveis de adicção na vida humana. Dessa forma, segundo Humberg (2014), sua perspectiva constitui um aprofundamento das proposições freudiana e kleiniana sobre a adicção, pois desenvolve outros aspectos das relações de objeto. Diferentemente da compreensão baseada nas posições esquizoparanoide e depressiva, Winnicott se ocupa de um tipo específico de objeto que não pode ser reduzido às vicissitudes da pulsão. Trata-se do objeto transicional - essencialmente derivado da atividade do brincar-e dos fenômenos transicionais, tomados como eixo central para a compreensão das adicções.

A maneira como a criança habita o mundo e se relaciona com ele, compreendida como conquista relacionada aos fenômenos transicionais por Winnicott (1975), é inaugurada nos primeiros meses de vida. Trata-se de um passo do amadurecimento saudável no qual a condição de unidade se estabelece para o bebê, assim como as referências de interior e exterior. Porém, para o autor, o interno e o externo não são áreas da experiência suficientes para compreender as perspectivas de relação do sujeito com o os diversos objetos da vida. O psicanalista inglês concebe, portanto, uma terceira área intermediária nomeada de "espaço transicional" ou "potencial". Este espaço intermediário permite a conciliação entre as percepções subjetivas e objetivas. Consiste em uma área de ilusão e criação, na qual o bebê vive a experiência paradoxal de criar e encontrar, fundamental para uma presença na vida sentida como real e significativa.

Os objetos e fenômenos transicionais constroem a possibilidade de separação e discriminação entre o bebê e o mundo, pois o objeto transicional consiste na primeira posse não-Eu como alteridade. Trata-se de um paradoxo em que a separação e a união dos mundos interno e externo coexistem. Essa experiência fundante permite o reconhecimento e relação com o mundo objetivo, compartilhado e, ao mesmo tempo, carregado de presença subjetiva, derivada dessa terceira área da experiência humana que abre caminho para o recurso da simbolização. Nessa travessia, o bebê passa a ser capaz de sus- 
tentar a experiência de presença na ausência de sua mãe, possibilidade que se desdobra para os variados objetos da vida (WINNICOTT, 1975).

O objeto transicional deve deixar de receber investimento afetivo e, em um percurso em que tudo corre bem, ser abandonado, esquecido e perder seu significado após cumprir sua função. Esse destino ocorre porque os fenômenos transicionais se expandem para a vida cultural e abrem caminho para relacionamentos, trânsito pela vida sem perda da referência de si e do que é próprio. Winnicott (1975) compreende que é através da abertura adquirida com os objetos e fenômenos transicionais que a capacidade criativa, o brincar, o sonhar e as ligações religiosas se tornam possíveis. Por outro lado, quando a transicionalidade não pôde ser suficientemente vivida, essa impossibilidade se torna a raiz de perspectivas de adoecimento emocional, por exemplo, do fetichismo, da delinquência, da indisponibilidade afetiva, da obsessividade e das adicções (WINNICOTT, 1975).

Nas adicções, constata-se a existência de uma ligação adictiva prematura como manifestação de um colapso do objeto e dos fenômenos transicionais. Winnicott (1975), ao descrever o desenvolvimento saudável, aponta que o uso de objetos como fraldas, panos, brinquedos de pelúcia e chupetas possibilita que o bebê tolere a separação gradual da mãe. Nesse momento fundamental, falhas graves do ambiente, que ultrapassam a capacidade da criança de suportá-las, impossibilitam o sujeito de conter intensidades extremas e arrebatadoras. Por conta de descaminhos dessa natureza, o bebê não adquire a capacidade de estar só na presença de outro e, consequentemente, a presença física e concreta da mãe é constantemente procurada. Assim como para os pacientes fronteiriços, existe nesses casos uma impossibilidade de dispor de um recurso transicional que viabilize a experiência de presença na ausência. Quando predominam um ambiente que falha com frequência, uma mãe mortificada emocionalmente ou inconstante demais, o objeto subjetivo não adquire a vitalidade necessária para passar da relação de objeto ao uso. O uso do objeto transicional, de acordo com Winnicott (1975), se dá somente quando o objeto subjetivo carrega as propriedades de estar vivo, ser real, suficientemente bom e não persecutório. Esse objeto "depende, quanto às suas qualidades, da existência, vitalidade e comportamento do objeto externo" (WINNICOTT, 1975, p. 24). A carência dessas características acarreta a transformação do objeto transicional em objeto- 
fetiche, que se mantém como traço na vida erótica no adulto (WINNICOTT, 1975, p. 24), com a importante consequência de poder se expressar como uma adicção.

Como exemplo dessa patologia da transicionalidade, Winnicott (1975) narra o caso de um menino de 7 anos de idade, atendido no Departamento de Psicologia do Hospital Paddington Green em 1955. O caso desse garoto, que viria a desenvolver adicção às drogas na adolescência, tornou-se notório como "o menino do cordão".

Winnicott tratou a criança com o jogo do rabisco (WINNICOTT, 1964), em consulta terapêutica, intervenção em que o paciente desenhou cordões, chicotes, ioiô, nós e laços. Em contato posterior com o psicanalista, os pais mencionaram esses desenhos e comentaram que esses conteúdos eram frequentemente produzidos pelo garoto. Também disseram que sempre encontravam mesas e cadeiras amarradas por ele.

Certa ocasião, encontraram a irmã menor do menino amarrada pelo pescoço com um cordão. O casal relatou diversas separações que haviam trazido sofrimento ao menino, inclusive devido ao nascimento da irmã e à ausência da mãe, que tivera depressão e fora internada. É possível inferir pelo relato do caso que o garoto sofreu graves consequências em sua constituição, devido a uma mãe emocionalmente ausente por certo tempo de sua vida.

Por residir no interior da Inglaterra, o menino não poderia seguir um processo psicanalítico tradicional. Winnicott (1975, p. 33-34) acreditou na capacidade dos pais de cuidarem do filho e orientou:

[...] expliquei à mãe que o menino estava lidando com um temor de separação, tentando negá-la através do uso de cordões, tal como, através do uso do telefone, se negaria à separação de um amigo. Ela se mostrou cética; disse-lhe, porém, que, se viesse a encontrar algum sentido no que eu estava dizendo, gostaria que debatesse o assunto com o menino em alguma ocasião conveniente, comunicando-lhe o que eu dissera e depois desenvolvendo o tema da reparação de acordo com a reação dele.

A mãe contou o que havia ocorrido com seu filho após seis meses da consulta terapêutica. Disse que, apesar de achar o gesto ridículo, conversou com seu filho sobre o tema. Ele estava ansioso para falar sobre seu relacionamento com ela e expôs o medo de que ela viesse a faltar. Lembraram juntos de várias separações pelas quais passaram e, após a conversa, o "brincar" com cordões cessou. Conversas como essa aconteceram em 
outros momentos, e a mãe constatou que a separação mais significativa foi a ausência dela, no período de sua depressão. Contudo, após uma década, Winnicott percebeu que a depressão materna se manteve ao longo do tempo, e o garoto desenvolveu uma série de vícios, em especial às drogas.

O mais relevante desse caso clínico para o presente contexto é que Winnicott (1975, p. 36) considera o cordão "como uma extensão de todas as outras técnicas de comunicação". Quando sua utilização é excessiva, pode indicar tanto sentimentos de insegurança ou de uma falta de comunicação. Nesse caso, a função do cordão se perverte, e modifica-se de "comunicação para negação da separação. Como negação, o cordão se torna uma coisa em si, algo que possui propriedades perigosas e necessidades que precisam ser dominadas". É fundamental ressaltar que no início essa utilização do cordão continha esperança. Segundo o autor (1975, p. 36):

Quando a esperança está ausente e o cordão representa uma negação da separação, surge então um estado de coisas muito mais complexo, um estado que se torna difícil de curar, por causa dos ganhos secundários oriundos da perícia que se desenvolve sempre que um objeto tem de ser manuseado a fim de ser dominado.

Por outro lado, nesse caminho da formação de uma adicção, o autor aponta para dois tipos de falhas ambientais: a demasiada ausência do objeto externo para o bebê e a maneira como se dá a separação do objeto transicional, com a grave consequência de a mãe ser tomada como o próprio objeto transicional. Tais falhas do ambiente acarretam a formação de um Ego frágil, para o qual a dependência materna e do outro se tornam um destino nos moldes de uma compulsão. Além disso, perfilam entraves relacionados às dissociações que podem levar à ruptura da integridade psicossomática e de personalização, isto é, distorções na experiência de habitar o próprio corpo (WINNICOTT, 1975).

Tal concepção do desenvolvimento emocional destaca que a formação da adicção não é determinada pelo objeto, seja uma droga, seja qualquer outro nesse lugar, porém advém de uma constituição inicial marcada por precariedade e falha, na qual algo Self e objeto - não se formou suficientemente bem. Assim, o encontro com o objeto de adicção conduz a uma relação adictiva devido à busca originalmente esperançosa por um acontecimento inicial que não ocorreu, falência da experiência da ilusão, criação, 
presença e coexistência. Tentativa de cura tingida de esperança que pode ser distorcida, pervertida, nunca encontrada e, portanto, patológica.

A partir desse olhar, é possível compreender que a relação entre esperança e desesperança ocorre de forma paradoxal, pois esses dois estados podem coexistir e compor dolorosa busca. O encontro com o objeto de adicção é marcado pelo frisson da intensidade de um encontro que, ao mesmo tempo, está destinado a se desfazer e cuja transitoriedade conduz o sujeito a uma trilha sem fim. Eis, assim, um caminho derivado da impossibilidade de constituição da transicionalidade, que construiria no indivíduo a capacidade de suportar a separação, assim como o acesso interno ao objeto que, pelo descaminho do suporte ambiental, está ausente. Falência que se estende à possibilidade de simbolização, de estar e não estar presente ao mesmo tempo, paradoxo fundamental para a constituição da subjetividade humana (WINNICOTT, 1975).

Dessa forma, Winnicott (1971) destaca uma busca fundamental na adicção que só pode ser respondida a partir da relação com os objetos transicionais e de seu uso: a possibilidade de união com os objetos da vida e de separação em relação a eles. Segundo Winnicott (2000/1953, p. 331): "A adicção pode ser descrita como uma regressão a um estágio em que os fenômenos transicionais não eram questionados". A adicção, como descaminho da transicionalidade, surge como substituição dos objetos e fenômenos transicionais, assim como um substituto da mãe ausente (GURFINKEL, 2011).

Nessa perspectiva, Gurfinkel (2001) apresenta os destinos dessa falha do espaço e do objeto transicional:

A adicção pode ser compreendida então como parte da psicopatologia manifestada nas áreas dos fenômenos transicionais, já que a droga, no caso, é um objeto-fetiche que expressa o fracasso na passagem do estágio de dependência absoluta para a dependência relativa. A função de objeto-fetiche é modificada de elemento de comunicação para negação da separação, e aqui encontramos uma falha simbólica que marca profundamente a vida do sujeito. (GURFINKEL, 2001, P. 226)

Humberg (2014) complementa o conceito com a importante ressalva de que os fenômenos transicionais não se restringem apenas aos objetos criados e encontrados, pois o próprio Self é criado e encontrado nesse processo. A capacidade de relacionamento com objetos, nessa perspectiva relacional e transicional, também diz respeito ao nas- 
cimento da possibilidade de brincar e de simbolizar (WINNICOTT, 1953/2000, p. 19). Constata-se, a partir desse recorte, que o drama contido na constituição das adicções consiste fundamentalmente em patologia da diferenciação, dos limites entre o dentro e o fora, ou seja, do colapso da intersecção dessas referências no registro do "entre" e, portanto, da impossibilidade de conter um objeto estável. Todos aspectos bastante próximos da dinâmica do fronteiriço. As falhas ocorridas no percurso inicial da transicionalidade acarretam importantes reações, principalmente a busca por um objeto que substitua o objeto transicional e os fenômenos transicionais. Além disso, uma tendência regressiva de isolamento pode se instalar, num movimento autístico (FÉDIDA, 2002), traço característico das toxicomanias, por exemplo.

Segundo Winnicott (1971), as adicções manifestam-se basicamente em dois modos de reação: o objeto de adicção ocupa o lugar do objeto-fetiche ou carrega a função de promover algum tipo de sensação. Ou seja, nesses casos, apresentam-se tanto a gênese de objetos-fetiche como a gênese de modelos de relação objetal que possibilitam as sensações de ligação com o mundo e de diferenciação dele. Winnicott (1975), em sua teoria dos objetos transicionais, concebe o fetichismo como um modelo para pensar as adicções sob um novo prisma. Nas palavras de Gurfinkel (2007, p. 21):

O que me parece ainda mais importante neste modelo de Winnicott é a possibilidade de pensar não apenas o fetichismo ou a toxicomania, mas uma "doença" fundamental da relação do sujeito com a realidade - patologia na área dos fenômenos transicionais -, que conduz ao uso fetichizado dos objetos e à inversão potencial entre sujeito e objeto, tornando-se o primeiro um sujeito quase, semimorto ou semivivo, escravo de um objeto metamorfoseado em coisa, portadora esta de atributos que seriam próprios do homem.

Dessa forma, as falhas ocorridas nesse momento de constituição da transicionalidade podem ser revividas de modo a reeditar intensidades e tensões do início da vida. Tal movimento entra em marcha na direção de uma solução capaz de restituir uma função transicional e é capaz de servir como um remendo da função materno-ambiental impossibilitada no passado. Assim, o elemento mais significativo a ser destacado é a esperança de encontrar - por meio de relações adictivas com uma substância, uma pessoa, um alimento ou qualquer outro objeto de adicção - vivências nunca completadas. 
Esperança regressiva de acessar acontecimentos fundantes e retornar a uma trilha perdida do contato com os objetos transicionais da infância, obturar uma lacuna e retificar uma experiência do passado (WINNICOTT, 1945h, p. 36) através de objetos postiços, como busca da possibilidade de união e separação de si e do mundo. Um movimento, portanto, de regate e recuperação dos alicerces para a relação com a realidade e seus objetos. Contudo, trata-se de um drama cuja solução está fadada ao fracasso em sua origem, por ser buscada por meio de recursos externos que promovem alívios transitórios do sofrimento emocional, através de lampejos nos quais o indivíduo é capaz de sentir-se vivo e real, assim como experimentar a presença dos outros e estar ligado a eles (HUMBERG, 2014).

A partir das apresentações sobre o fronteiriço e sobre a adicção na perspectiva winnicottiana, é possível apreender que a busca pelo outro no paciente fronteiriço, pela droga ou qualquer objeto de adicção, parecem ter a mesma função. Contudo, a droga e os demais objetos-coisa não são pessoas, não têm rosto e não respondem aos apelos contidos em movimentos tão vitais de busca. Essa procura por algo ou alguém, interna e externamente indisponível, falha pela ruína do registro intermediário da experiência e pode resultar em sofrimentos adictivos.

\subsubsection{André Green}

Green $(2002,1999,1990,1988 \mathrm{a}, 1988 b, 1982)$ se manteve muito próximo da psicanálise do fronteiriço, compreendendo-o como um novo paradigma para a psicanálise. Construiu um ponto de vista sobre esse campo psicanalítico que denominou de "metapsicologia do fronteiriço". Trabalhou componentes estruturais da psicodinâmica desses pacientes e não se ocupou da interlocução com a psiquiatria ou com a psicopatologia não psicanalítica.

Ao propor sua conceitualização, o autor (1977/1988b, p. 67) menciona que uma fronteira não constitui uma linha, mas um território, "uma terra de ninguém entre a sanidade e a insanidade". Com base em Winnicott (1971/1975), Green (1990) entende que a problemática desse espaço-limite consiste na inexistência ou no colapso de um terceiro território, região do "entre", espaço de elaboração e simbolização. Segundo ele, as principais angústias desses pacientes são de intrusão e de separação (perda do objeto) 
- embora a de castração também esteja presente, ela não é estruturante. O psicanalista destaca a somatização, o acting-out, a dissociação e o desinvestimento como componentes principais na dinâmica desses pacientes.

Para compreender a etiologia do fronteiriço, Green (1977/1988b) focaliza a trajetória de constituição e divisão do Ego. Frisa que a intensidade pulsional do bebê imaturo e dependente exige um outro devotado a agir como um objeto capaz de atender às necessidades do recém-nascido, e destaca o cuidado materno como um substituto do Ego inicial da criança.

O bebê ganha autonomia pela experiência de separação entre o seio e a própria criança. Trata-se de um processo gradual composto por um "vai e vem", oscilações entre momentos de discriminação e estados de integração ou de fusão com o seio/ objeto materno. O autor faz importante observação ao mencionar que frustrações são inevitáveis nesse percurso, e um recurso da criança é separar o bom do mau, o prazeroso do desprazeroso - disso decorre a distinção entre o Self e o objeto. Tal caminho de diferenciação estabelece as primeiras fronteiras da experiência humana e inaugura as referências de dentro e fora, somático e psíquico, fantasia e realidade, bom e mau.

Green menciona a dissociação como operadora de uma exclusão radical, em casos de comprometimento emocional grave. Pondera que o trabalho de divisão é fundamental para o psiquismo, que o bebê não deve ser sobrecarregado pela tensão e que necessita de mecanismos para se defender e sobreviver. Nos casos mais graves, entretanto, em vez de a divisão funcionar como uma delimitação necessária e útil, ela causa uma “amputação no Ego" (GREEN, 1988, p. 82).

Tais processos de divisão carregam diferentes sentidos, de acordo com o referencial teórico adotado em psicanálise. Para Freud e Klein, de acordo com Green (1988), são desdobramentos do efeito da pulsão de morte. Winnicott (1975), porém, compreende os processos de divisão e separação de forma distinta. Apesar de concordar com a existência de uma relação entre a divisão e a destrutividade, compreende que tal destrutividade inicial não pode ser percebida como tal por conta da imaturidade do Ego. Para o autor, as experiências destrutivas consistem em agonias impensáveis e o ambiente é essencial na contenção desses estados de desintegração.

Green (1988) aponta a confusão no caminho de constituição do fronteiriço, que se dá em duas direções, por conta da divisão: incapacidade de fusão por parte da mãe, 
na qual o bebê se depara com "seios em branco", ausentes. Por outro lado, há um excesso de fusão, manifestado pela incapacidade materna de renunciar, em favor do crescimento do filho, ao êxtase da experiência de gravidez e de posse. Como resultado desse processo, manifestam-se concomitantemente angústias de intrusão e de separação, características peculiares dos pacientes fronteiriços.

Segundo Green (1988a), a separação criança-seio resulta em um duplo trato, uma aliança que relaciona mãe e filho com referência a uma terceira parte potencial, ou seja, o pai, que está presente desde o início no psiquismo materno. Dessa forma, instalase um paradoxo, pois o resultado desta divisão é que algo será excluído, tornando-se elemento impensável, consequentemente ocorrerá uma polarização "perda-intrusão".

O sofrimento do fronteiriço circunscreve-se ao circuito dentro e fora, exclusão e inclusão, divisões internas incomunicáveis, a separação do corpo em relação à mente, etc. Green (1988) amplia esse conceito: vai além do interno e externo, acrescentando que existe uma divisão psique-soma. Tal segregação resulta na dissociação entre sensações corporais e afetos, que por sua vez pode adotar contornos tênues como o processo de distanciamento entre afeto e pensamento. Além da divisão do Ego, ocorre outro modo de divisão entre o psíquico e não psíquico. Nesse cenário, o recurso de diferenciação entre recalque e divisão é fundamental. O retorno das ideias recalcadas suscita a ansiedade, ao passo que o retorno dos componentes cindidos e dissociados desencadeia perturbações de pujante ameaça, sentimentos de profundo desamparo, aniquilação e angústias impensáveis.

Green (1988) evidencia que a particularidade do borderline incide precisamente na coexistência dos dois níveis decorrentes da divisão. O primeiro nível diz respeito ao somático e ao mundo externo, ou seja, à separação entre o psíquico e o não psíquico; o segundo compreende elementos de qualidade intrapsíquica. A separação entre mundo interno e mundo externo ocorre por meio da composição de um continente em torno do Ego com fronteiras bem definidas, mas que não podem exercer a função de "escudo protetor". Os contornos do Ego são bastante complacentes, contudo essa característica flexível não gera suficiente efeito adaptativo para o fronteiriço. Este se ocupa com um trabalho de flutuação da expansão e retração simultaneamente para enfrentar a angústia de separação ou perda e a angústia de intrusão ou de implosão, ou as duas ao mesmo tempo. 
Embora esses pacientes possuam tal Ego flexível, não conseguem apreender esas flexibilidade, de modo que ela não contribui para o enriquecimento da experiência. O que ocorre é que essa mobilidade egoica ocasiona confusão e perda de controle, como defesa estrema frente à implosão, à desintegração ou à perda. O escudo egoico é ineficiente para proteger o Ego frágil, "tanto rígido como carente de coesão" (GREEN, 1988, p. 85). Nesse ponto, o autor introduz o conceito de arquipélago, ou seja, o Ego é composto de núcleos distintos, separados, que não se comunicam.

A existência simultânea de núcleos que não se comunicam acarreta uma vivência de confusão e falta de coesão do Self, e ainda, uma precariedade de identidade como consequência desse desmembramento. Essa falha da integração do Ego se expressa em pensamentos e afetos contraditórios - e, do ponto de vista de quem observa, gera a marca de um sentimento de indiferença e de desvitalização. Como se esses núcleos egoicos separados, assim como as relações de objeto separadas, não desempenhassem o papel de criar uma pessoa integrada (GREEN, 1988b).

Green (1988c) afirma que também se manifestam como consequências desse psiquismo desintegrado o sentimento de futilidade, falta de consciência de presença, contato prejudicado, inabilidade de formar representações mentais, dificuldade de concentração e bloqueio do pensamento, resultantes de descatexia e desobjetalização. Esses estados de dissociação são desconectados da experiência de afetos e da dor, tal como uma "mente em branco". O autor denomina de "depressão primária" esse conjunto de sintomas. Segundo esse conceito, todos os mecanismos de defesa, ou seja, identificação projetiva, negação, onipotência e outros, são decorrentes dessa fragmentação.

O autor (GREEN, 1988) explica que, no caso dos pacientes borderline, as relações objetais apresentam como aspecto singular fixações e regressões pré-genitais. Acresenta que essa dinâmica assemelha-se ao Complexo de Édipo pelo aspecto da triangulação, exceto pelo fato de que as figuras parentais são vivenciadas, do ponto de vista emocional, como polos opostos. Nesses casos há experiência de separação entre as figuras parentais, conectada à ideia de bom e mau, idealizado e persecutório. Dessa forma, de maneira extrema, a um dos pais é atribuída a conotação de totalmente bom e ao outro a de totalmente mau, sendo o objeto bom experienciado como ineficiente e fraco. Trata-se de um excesso que idealização do bom que falha ao tentar proteger o sujeito da maldade onipotente e poderosa do outro, pai ou mãe. Contudo, de acordo com o autor, o indivíduo 
teme de fato a separação do objeto mau mais do que as qualidades grandiosas atribuídas a ele, de forma que esse medo do abandono instaura uma experiência de desamparo, em que o objeto bom encontra-se afastado, indisponível e inconstante.

Outro aspecto fundamental evidenciado por Green (1988) é que a elaboração acontece de maneira imprecisa e contraditória, pois não ocorre a diferenciação entre as representações, os pensamentos e os afetos. O pensamento está repleto de afetos penosos e intensos, que não podem ser diferenciados das intensidades pulsionais, prejudicando o processamento do pensar racional. A discriminação parcial pode ocorrer às custas de cisões drásticas, e deste processo resultam as fantasias de onipotência e crenças mágicas, com traços narcísicos.

Green (1988) faz relevante comparação das importantes concepções de Kernberg e Bergeret sobre o fronteiriço, que teoricamente apresentam oposição no que diz respeito à estruturação ou anestruturação do borderline. Contudo, acrescenta que esses dois autores apresentam afinidade com o pensamento freudiano, observação que reconhece a coerência e proximidade do pensamento desses autores, não obstante tal divergência.

Em relação à temática dos fenômenos transicionais, conceituados por Winnicott em 1975, Green (1988) escreve que os pacientes borderline apresentam dificuldade e impedimento para percorrer a transicionalidade. Embora capazes de criar precariamente objetos e fenômenos transicionais, estes não possuem qualidade funcional como para outros indivíduos, pois, ao criar o objeto, os pacientes borderline criam sintomas que preenchem a função dos fenômenos transicionais. Assim sendo, pode-se pensar o outro coisificado ou uma droga como um esforço de construir e constituir esse objeto transicional, que por sua vez não exerce sua função e, desta forma, não pode ser esquecido e deixado.

Green (1982) faz relação direta entre toxicomanias e os estados fronteiriços, ambos caracterizados por movimentos de alternância de perda e recuperação objetais. Para o autor, o estatuto do objeto interno é de constante ameaça, "perpetuamente destinado ao desaparecimento" (p. 157). Contra as ameaças de perda são realizadas buscas de recuperação objetal desesperadas, imediatas e a qualquer custo. Tais tentativas são fundamentais na luta estabelecida contra os afetos depressivos ou de fragmentação, e reivindicam uma redescoberta por objetos que possam assumir o lugar do objeto buscado. Para o autor, o objeto da toxicomania tem por finalidade prevenir ou reparar uma perda objetal, sendo o adicto movido por uma angústia análoga à dos estados fronteiriços. 
Conforme o autor, tanto o adicto como o fronteiriço demandam uma garantia de que tal objeto possa ser encontrado no exterior e incorporado, busca esta que deve ser reiteradamente empreendida, por uma espécie de estado de "desnutrição afetiva permanente" (GREEN, 1982, p. 158). São sujeitos com fome e sede de objeto - sede de uma relação que não aconteceu -, e que buscam, de fato, incorporar um outro exterior capaz de restaurar alguma presença e constância. Além disso, essa procura desesperada se dá também na tentativa de reparação dos efeitos de pulsões destrutivas, que mostram suas marcas através da experiência evidente de vazio. Desse movimento, portanto, decorre uma necessidade de reconstrução narcísica.

Green considera problemática, nessa dinâmica, a impossibilidade de introjetar afetos derivados da relação com tal objeto instável, pois essa inaptidão acarreta a necessidade de buscar um outro que promova intensidade e perturbação, como uma droga. No caso da toxicomania, assim como nos fronteiriços, a escolha do objeto externo se dará conforme seus efeitos sobre o afeto. O ponto central dessa busca é a esperança por um "sinal de vida", contra o silêncio afetivo e objetal, luta contra uma ausência e falha fundamentais, uma ameaça de morte estabelecida como presença. No caso da toxicomania, o autor menciona a batalha contra uma "frigidez narcísica", sensação de miséria afetiva, como no caso de inanição, do ponto de vista orgânico. Contudo, afirma que a busca pela droga consiste em uma revitalização mortífera, visto que a substância, incapaz de neutralizar a vivência de vazio, consegue apenas aplacar a dor afetiva por um período.

\subsubsection{Otto Kernberg}

A importante contribuição de Kernberg (2006, 1995a, 1995b, 1991, 1984, 1979, 1976, 1975) consiste em fornecer um lugar basilar para o sofrimento do fronteiriço, com estatuto etiológico, estrutural, psicodinâmico e psicopatológico próprios e inconfundíveis. Trata-se de um autor que realizou contribuição essencial para o desenvolvimento do conceito de fronteiriço (GREEN, 1988). Propõe uma delimitação clara do paciente fronteiriço (KERNBERG, 1991, 1995, 2006), abarcando o olhar de outros autores e oferecendo grande precisão diagnóstica (HEGENBERG, 2000). Considera que os traços do paciente, seu grau de integração de identidade, os tipos de operações defensivas utilizadas e a capacidade de teste de realidade refletem o tipo de organização. 
Para ele, há três estruturas - neurótica, psicótica e borderline -, que fazem a mediação entre os elementos etiológicos e a expressão direta da psicopatologia. Os sintomas se desenvolvem sobre uma estrutura psíquica, matriz composta por fatores genéticos, constitucionais, bioquímicos, familiares, psicodinâmicos ou psicossociais. No caso da estrutura borderline, o autor dá ênfase para a difusão da identidade e o teste de realidade preservado, porém com a presença de defesas primitivas próprias da psicose. $\mathrm{O}$ quadro descrito e teorizado pelo autor expõe as marcas e o funcionamento dinâmico próprio desses pacientes, concebidos por ele como "organização borderline de personalidade". Trata-se de uma conceitualização que permite a apreensão do fronteiriço a partir de limites e traços bastante definidos.

Tabela 1. Diferenciação da Organização de Personalidade (KERNBERG, 1995 p. 19)

\begin{tabular}{|c|c|c|c|}
\hline & NEURÓTICA & BORDERLINE & PSICÓTICA \\
\hline \multirow[t]{2}{*}{$\begin{array}{l}\text { INTEGRAÇÃO } \\
\text { DA } \\
\text { IDENTIDADE }\end{array}$} & \multicolumn{2}{|c|}{$\begin{array}{l}\text { Representação do Self e do objeto são claramente } \\
\text { delimitadas. }\end{array}$} & $\begin{array}{l}\text { Representações do Self e } \\
\text { do objeto são mal delimi- } \\
\text { tadas ou há uma identidade } \\
\text { delirante. }\end{array}$ \\
\hline & & \multicolumn{2}{|c|}{$\begin{array}{l}\text { Difusão de identidade aspectos contraditórios do } S e l f \text { e } \\
\text { dos outros são mal integrados e mantidos separados. }\end{array}$} \\
\hline \multirow{3}{*}{$\begin{array}{l}\text { OPERAÇÕES } \\
\text { DEFENSIVAS }\end{array}$} & $\begin{array}{l}\text { Recalcamento de defe- } \\
\text { sas de alto nível: for- } \\
\text { mação reativa, anula- } \\
\text { ção, racionalização, } \\
\text { intelectualização. }\end{array}$ & & $\begin{array}{l}\text { As defesas protegem o } \\
\text { paciente da desintegração e } \\
\text { da fusão Self-objeto. A } \\
\text { interpretação leva à regres- } \\
\text { são. }\end{array}$ \\
\hline & \multicolumn{2}{|c|}{$\begin{array}{l}\text { As defesas protegem o paciente do conflito intrapsí- } \\
\text { quico. A interpretação melhora o funcionamento. }\end{array}$} & \\
\hline & & \multicolumn{2}{|c|}{$\begin{array}{l}\text { Principalmente a clivagem e as defesas de baixo nível: } \\
\text { idealização primitiva, identificação projetiva, denegação, } \\
\text { onipotência, desvalorização. }\end{array}$} \\
\hline \multirow{3}{*}{$\begin{array}{l}\text { TESTE DA } \\
\text { REALIDADE }\end{array}$} & \multicolumn{2}{|c|}{$\begin{array}{l}\text { Capacidade de testar a realidade é preservada, as } \\
\text { origens intrapsíquicas e as externas das percepções e } \\
\text { estímulos. }\end{array}$} & \\
\hline & & \multicolumn{2}{|c|}{$\begin{array}{l}\text { Alterações ocorrem na relação com a realidade e nos } \\
\text { sentimentos sobre a realidade. }\end{array}$} \\
\hline & & & $\begin{array}{l}\text { A capacidade de testar a } \\
\text { realidade é perdida. }\end{array}$ \\
\hline
\end{tabular}


Kernberg evidencia que os pacientes borderline são marcados por importante experiência de vazio crônico, autopercepções pobres e contraditórias, além de dificuldade de se apresentar ao terapeuta. Nesse sentido, a difusão de identidade constitui a primeira e mais importante referência diagnóstica para esse autor, revelada na impossibilidade de integração do conceito de Self, assim como na integração dos traços subjetivos de outras pessoas (KERNBERG, 1995).

Para ele, a organização borderline e a psicótica caracterizam-se pela predominância de defesas primitivas fundadas no mecanismo de clivagem (KERNBERG, 2006, 1995, 1991), aspecto tomado como segundo elemento diagnóstico mais relevante, enquanto na organização neurótica as operações defensivas são fundadas predominantemente no recalcamento. Kernberg frisa que os processos defensivos têm a importante função de proteger o Ego de conflitos e ambivalências insustentáveis, por dissociarem elementos contraditórios do Self. Dentre os principais mecanismos presentes na organização borderline, o autor aponta a idealização primitiva, identificação projetiva, negação, controle onipotente e desvalorização.

O mecanismo de clivagem é compreendido pelo autor como cisão do Self e dos objetos entre "totalmente bons" e "totalmente maus". Esse processo defensivo promove a radical e total inversão dos sentimentos e percepções subjetivas sobre o próprio Self ou sobre a imagem de outra pessoa. Tal processo é complementado por idealizações primitivas que exacerbam a apreensão do outro como figura absolutamente boa, a ponto de defeitos humanos corriqueiros não serem considerados. A marca relevante dessa formação está na incapacidade de suportar qualquer imperfeição na figura idealizada. Ao mesmo tempo, e inversamente, se dá absoluta e tirânica desvalorização dos outros, frequentemente apresentada na percepção dessas figuras como persecutórias e ameaçadoras (KERNBERG, 1991, 1995; CLARKIN; YEOMANS; KERNBERG, 2006). 
Figura 1 - Organização do split (da divisão) - consciência de tudo bom ou tudo mau (CLARKIN; YEOMANS; KERNBERG, 2006, p. 186)

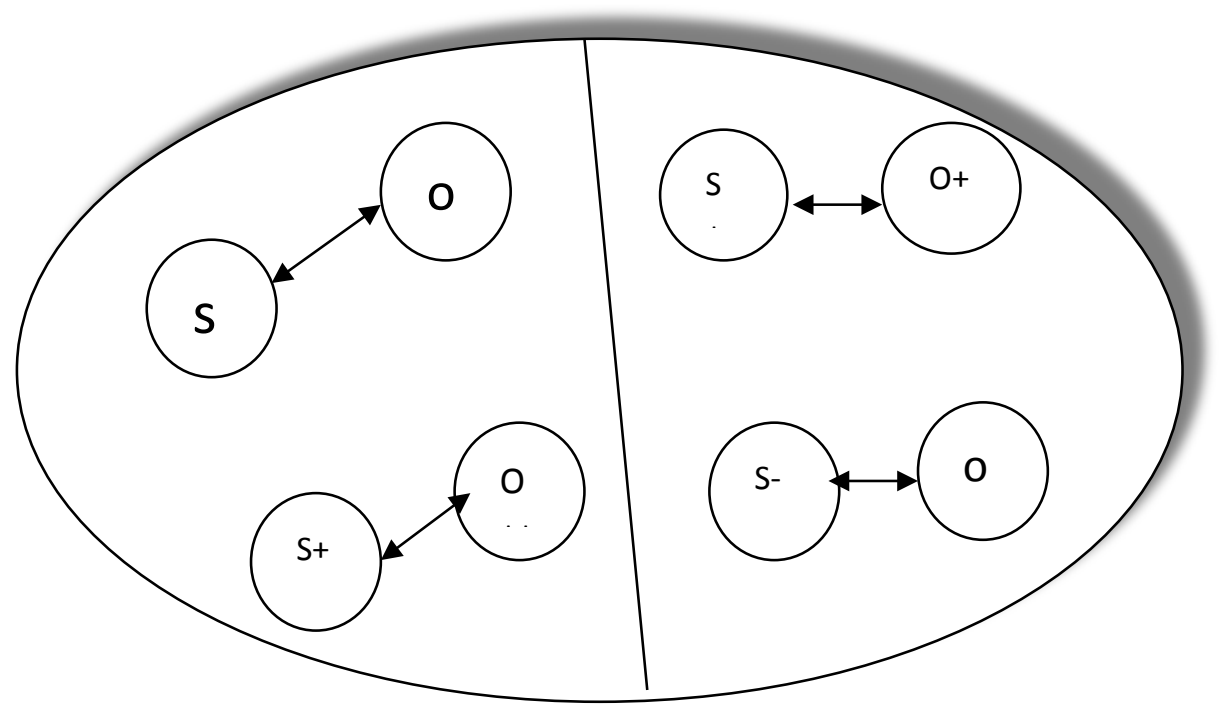

\section{Legenda}

S Representação de Self carregada de afeto negativo

O Representação do objeto carregada de afeto negativo

S+ Representação de Self carregada de afeto positivo

$\mathrm{O}+$ Representação do objeto carregada de afeto positivo

Kernberg compreende que tanto a onipotência como a desvalorização derivam da clivagem, sendo expressas por um estado egoico que remete ao Self inflado, grandioso e onipotente do fronteiriço. Essa condição se soma às representações desvalorizadas dos outros, incluindo a projeção de aspectos desvalorizados do Self. Desse conjunto de recursos primitivos de defesa do Ego também consta a identificação projetiva. Trata-se de um movimento de invasão do outro e de sua percepção, como se esse outro estivesse sendo controlado pelo impulso projetado. Esse mecanismo se baseia na necessidade de controlar o objeto de fato e provocar uma resposta no outro que confirme tal projeção.

Segundo o autor (KERNBERG, 1995a), embora o fronteiriço tenha consciência de suas percepções, pensamentos e sentimentos sobre si e sobre os outros, essas percepções, pensamentos e sentimentos podem ser radicalmente opostos ao que ele expressa. 
Assim, a negação se dá por meio de áreas emocionalmente independentes de consciência e sem integração, concepção próxima do conceito de arquipélago ${ }^{7}$ (GREEN, 1988).

Kernberg $(2006,1995 \mathrm{a}, 1995 \mathrm{~b}, 1991)$ apresenta como terceiro elemento diagnóstico do fronteiriço a condição preservada do teste de realidade, diferentemente da organização psicótica. Trata-se da capacidade de diferenciação Self / não-Self, além da discriminação das origens interna e externa das percepções.

A partir dessa concepção de organização borderline de personalidade, verificase que os dois primeiros critérios estruturais diferenciam as estruturas borderline das neuroses e do falso Self. Por sua vez, o terceiro critério contribui para o diagnóstico diferencial entre borderline e psicose. Além disso, a concepção de um teste de realidade preservado no fronteiriço constitui alvo do presente estudo, sobretudo ao afirmar que a percepção da distinção entre Self e não-Self permanece estável frente à ameaça e à experiência de perda e abandono. Nesse aspecto parece haver uma distorção circunscrita à qualidade da relação objetal e do Self, diante da experiência de desestruturação emocional pela perda do outro, como comprometimento do teste de realidade.

De qualquer maneira, o autor compreende que os pacientes borderline não puderam consolidar a constância objetal após os três anos de idade de maneira satisfatória. Por isso, não são capazes de compor uma visão integrada da mãe, não dispõem dessa figura interna minimamente consistente e estável, capaz de tranquilizá-los em momentos de ausência do objeto. Dessa forma, experimentam a vida e o outro marcados pela ameaça e a consequente intolerância à separação e à solidão. Para o autor, o produto desse processo é uma condição caracterizada pelo povoamento de objetos maus introjetados, não apenas a ausência de um objeto bom (KERNBERG, 1991, 1995, 2006).

Tal falta de constância objetal é um importante fator da organização psíquica do fronteiriço, que, frente ao percurso de separação e individuação em seu desenvolvimento, não pôde integrar aspectos bons e maus de si e de sua mãe. Assim, tais referências contraditórias permanecem dissociadas, de modo que tanto a mãe como o Self são percebidos ora como totalmente bons, ora como totalmente maus.

Kernberg também relaciona a impossibilidade de integrar imagens boas e más do Self e dos outros a um excesso constitucional de agressão oral, a qual leva os pacien-

\footnotetext{
${ }^{7}$ Segundo Green (1988), a divisão interna do fronteiriço revela que o ego é composto de núcleos diferentes, separados, que não se comunicam, os quais o autor denomina de "arquipélago".
} 
tes borderline a acreditar que uma intensa maldade irá destruir todos os aspectos bons neles ou em outros. Devido à projeção desses aspectos maus introjetados, eles se sentem vulneráveis e perseguidos. Quando reintrojetadas, as introjeções más os fazem sentir-se indignos e desprezíveis, fato que ocasionalmente os leva a pensamentos autolesivos e suicidas, fenômeno clínico bastante comum nesses casos.

\subsubsection{Jean Bergeret}

Bergeret $(2006,1998,1991,1986,1975)$ adota a angústia central como critério diagnóstico fundamental do paciente fronteiriço, nomenando-o "organização limite de personalidade". Para ele, há as estruturas neurótica e psicótica, que apresentam angústias básicas distintas, e podem estar compensadas ou descompensadas. A noção de saúde consiste, assim, na estabilidade dentro da própria estrutura, de modo que a compensação - e não a transposição para outra estrutura - é considerada como direção de cura. Já os casos-limite carregam uma condição de não estruturação, ou anestrutura, que nunca se manifesta como realmente compensada. Portanto, as personalidades neurótica e psicótica constituem estruturas para o autor, por sua vez as organizações limite seriam, como a própria terminologia explicita, organizações. Enquanto a estrutura é tomada como constituída, definitiva e sólida, as organizações são marcadas por seu caráter provisório, mesmo que sigam em relativa estabilidade ao longo do tempo.

Tabela 2. Comparação entre as linhagens estruturais (BERGERET, 1991)

\begin{tabular}{|l|l|l|l|l|l|}
\hline & $\begin{array}{l}\text { Instância } \\
\text { Dominante na } \\
\text { Oganização }\end{array}$ & $\begin{array}{l}\text { Natureza } \\
\text { do Conflito }\end{array}$ & $\begin{array}{l}\text { Natureza } \\
\text { da Angústia }\end{array}$ & $\begin{array}{l}\text { Principais } \\
\text { Defesas }\end{array}$ & $\begin{array}{l}\text { Relação } \\
\text { de Objeto }\end{array}$ \\
\hline $\begin{array}{l}\text { Estruturas } \\
\text { Neuróticas }\end{array}$ & Superego & $\begin{array}{l}\text { Superego } \\
\text { com o id }\end{array}$ & De castração & Recalque & Genital \\
\hline $\begin{array}{l}\text { Estruturas } \\
\text { Psicóticas }\end{array}$ & Id & $\begin{array}{l}\text { Id com a } \\
\text { realidade }\end{array}$ & $\begin{array}{l}\text { De } \\
\text { fragmentação }\end{array}$ & $\begin{array}{l}\text { Negação } \\
\text { da realidade. } \\
\text { Desdobramento } \\
\text { do Ego }\end{array}$ & Fusional \\
\hline $\begin{array}{l}\text { Estruturas } \\
\text { Limítrofes }\end{array}$ & Ideal de Ego & $\begin{array}{l}\text { Ideal de Ego } \\
\text { com: } \\
\text { - Id } \\
\text { - Realidade }\end{array}$ & $\begin{array}{l}\text { De perda } \\
\text { do objeto }\end{array}$ & $\begin{array}{l}\text { Clivagem dos } \\
\text { objetos. } \\
\text { Forclusão }\end{array}$ & Anaclítica \\
\hline
\end{tabular}


Sobre a origem dessa organização, Bergeret propõe que o Ego dos fronteiriços superou importantes desestruturações durante o período em que as relações precoces poderiam conduzir a uma pré-organização psicótica. Porém, na travessia em direção ao complexo de Édipo, há marcas traumáticas determinantes, relacionadas, principalmente, ao risco de perda do objeto. Essas marcas decorrem de experiências excessivamente intensas, em um momento no qual o Eu ainda se encontra pouco organizado. Ocorre uma vivência prematura e violenta do enredo edípico, experimentada como traumática, que não pode ser absorvida e elaborada pela criança a partir de um posicionamento emocionalmente maduro.

Nesse drama precoce, um movimento defensivo conduz o Eu da criança a uma integração precária e antecipada dessa experiência. Esse percurso defensivo levará, segundo o autor, à impossibilidade de uma triangulação edípica, ou seja, prejudicará a capacidade de se apoiar no amor do pai e suportar o ódio direcionado à mãe, assim como o inverso. Também impedirá o recurso do recalcamento, para retirar da consciência as intensidades sexuais ou agressivas. Lançará mão, assim, de mecanismos de defesa de natureza psicótica, como a identificação projetiva, a clivagem do objeto (e não do Eu), a negação de representações sexuais (e não da realidade) e controle onipotente do objeto. Para o autor, é o impedimento do amadurecimento afetivo do Eu, em estágio de indiferenciação sexual, que leva ao que nomeou de "tronco comum dos estados limites" (BERGERET, 2006).

O aspecto mais relevante para a discussão ora proposta é que, para o autor, o fronteiriço supera a constituição de natureza psicótica, porém não alcança a estruturação neurótica - e, principalmente, mantém sua relação de objeto fundada na dependência anaclítica do outro. As relações de objeto acontecem a dois, mas não como a dupla primitiva típica das psicoses. Nesse caminho, o sujeito inclina-se na busca por estar ligado a um outro forte e grandioso, apartado, como objeto distinto - e ao mesmo tempo apoiase contra ele, de acordo com a etimologia do termo "anaclitismo" (BERGERET, 1998).

Segundo Bergeret (1998, p. 123), a palavra "anáclise" advém do grego anaklitos, que significa "achar-se virado para trás, deitado sobre o dorso, de forma essencialmente passiva". Os sentidos que derivam desse termo grego remetem às ideias de "dobrar-se sobre", "inclinar-se para", "deitar-se contra". Em suma, movimentos próprios da organização limite, que busca fundamentalmente apoiar-se no outro. Torna-se impres- 
cindível destacar esse movimento anaclítico apresentado pelo autor, porque a anáclise revela a angústia subjacente e a tentativa de não perder o objeto, pois sem ele o indivíduo mergulhará em estados de depressão disruptiva, distinta da melancolia, sem o objeto introjetado.

A angústia central desses pacientes é a perda do objeto, marca fundamental da organização limite de personalidade. Essas pessoas podem passar por períodos de sofrimento mais ou menos agudo e ganhar estabilidade em direção a uma estruturação como conquista terapêutica. A angústia de depressão também perfila como elemento importante nesses pacientes. Trata-se de drama relacionado a uma dinâmica predominantemente narcisista, em detrimento da pulsional e erótica. $\mathrm{O}$ autor parte de uma visão de abertura que permite trânsito e compreende que os sintomas guardam uma independência; afasta-se, portanto, de um olhar determinista em termos de destino clínico (BERGERET, 1998).

É importante destacar que, para o autor, a descrição dessas personalidades é muito similar àquilo que considera sobre as toxicomanias, caracterizadas por exuberante imaturidade afetiva, que leva ao impedimento de uma estruturação consistente, seja de forma neurótica, seja psicótica. Ao discorrer sobre as chamadas personalidades toxicomaníacas psicóticas e neuróticas, Bergeret (1991) considera que os pacientes fronteiriços estão incluídos no subgrupo nomeado de "depressivos", que representam a categoria mais relevante entre todos os toxicômanos, pela intensidade das relações de dependência e pela dinâmica mais propensa à toxicomania. Para o autor, a organização psíquica, concebida sob o prisma estrutural, é que irá predispor à aderência à droga e à dependência. Em outras palavras, a precária organização afetiva e o ânimo amedrontado pelo isolamento e pelo descrédito em relação a si mesmos os conduz à adesão compulsiva a um outro, seja em uma relação a dois, seja em grupos de semelhantes. O autor salienta, nessa categorização, a intensa dependência aos outros, em pacientes marcados pela angústia e pelo risco de perda do contato com um outro vital. Destaca também a característica de serem pessoas muito disruptivas e suscetíveis em suas relações de objeto, além de apresentarem importantes perturbações narcísicas.

Além de proporcionar um lugar de destaque para o fronteiriço em sua obra, Bergeret frisa um aspecto nomeado como "caráter abandônico" ou "neurose de abandono". Presente em uma variedade de formações clínicas, mas fundamentalmente no bor- 
derline e na personalidade narcisista, esse componente é marcado por três traços essenciais: angústia de abandono, não valorização e agressividade reativa. Eis um ponto importante para a presente pesquisa, pois a ausência e o abandono são marcas predominantes na vida subjetiva do fronteiriço. Segundo Bergeret (1996), o sujeito fronteiriço, tomado por tal sofrimento, experimenta dificuldade em afirmar-se, duvida de suas próprias capacidades e do fato de ser amado pelos outros, assim como questiona sua possibilidade de enfrentá-los e de viver a experiência de ser significativo. Para o autor, a não valorização não tem origem em uma inibição, mas na agressividade reativa, compreendida como reivindicação e vingança em função falhas passadas. Esses pacientes demonstram uma tendência de procurar infligir aos outros um sofrimento análogo ao seu. A agressividade reativa, complementa o autor, visa desnortear e controlar o objeto, de forma a mantê-lo próximo e, sobretudo, com presença assegurada.

Bergeret (1996) descreve um sofrimento derivado desse quadro, no qual o sujeito permanece sempre em vigília, de forma que qualquer falta afetiva desencadeia uma vivência hostil, mesmo que evidentemente desconectada da história da relação e da segurança envolvida. O psicanalista aponta, ainda, a perpetuação de uma ambivalência arcaica na vida atual do sujeito, que o leva a reações drásticas frente à menor indicação de distância afetiva do outro, aspecto bastante relevante para a pesquisa ora apresentada.

\subsubsection{Joyce McDougall}

McDougall (2004, 1995, 1992), que se dedicou profundamente ao estudo das adicções, propõe que uma relação adictiva pode se constituir por falhas iniciais na relação mãe-bebê, decorrentes de angústias e desejos maternos inconscientes. Tal abordagem oferece fecundo subsídio para reconhecer no fronteiriço uma qualidade essencial de dependência. Trata-se de um percurso de desenvolvimento no qual a criança não se torna capaz de adquirir a presença interna de uma mãe cuidadosa, com que possa se identificar e que lhe permitiria suportar estados de sofrimento emocional.

O bebê que não se torna capaz de criar tal presença minimamente consistente em sua vida emocional não será capaz de suportar intensidades emocionais acentuadas e inconstâncias internas ou externas. Assim, seu destino será procurar supressões no mundo externo para essa função. Diversas formas de adicção se apresentam como re- 
cursos transitórios, a fim de cumprir a função original que o adicto não pode realizar. Tais objetos de adicção tomam o lugar dos objetos transicionais da infância que falharam e poderiam abrir caminho para a separação e simbolização (MCDOUGALL, 1992).

Tomando como base o referencial winnicottiano, a autora atribui a busca por objetos adictivos às relações primitivas entre mãe e filho, principalmente na fase de dependência absoluta. O percurso dessa relação determinará marcas fundamentais na capacidade da criança para estar só em presença do outro e no desenvolvimento dos fenômenos transicionais, assim como nos destinos da libido. As características dessa relação inicial propiciam a configuração de uma relação adictiva com a presença concreta e com os cuidados maternos, pois o bebê não conta com a constância de tal presença. Em outras palavras, a criança não pode viver a experiência de ilusão necessária para criar esse objeto intermediário e uma representação consistente dele. Destaca-se como consequência, principalmente, a perspectiva das relações adictivas, uma modalidade de vício a outra pessoa, que será abordada adiante neste capítulo.

Embora a terminologia empregada por McDougall denote referência representacional, a autora compreende a adicção como um drama relacional fundado em entraves ligados à separação e à integração. Para ela (1995), o objeto de adicção ocupa postiçamente o lugar do ambiente que falhou, de uma mãe que não pôde promover sustentação suficiente para o filho em momentos iniciais da vida. Nesse arremedo de ambiente, uma espécie de autocuidado ambíguo, esse objeto substitutivo se torna, ao mesmo tempo, coisificado e vital, passível de ser controlado e acessado como alívio de graves angústias.

A adoção da droga, de outro objeto ou mesmo de uma pessoa como substituto do ambiente visa aplacar o risco de reencontro com falhas ambientais vividas no passado. Tal ambiguidade, em relação ao objeto de adicção, reside na inversão ilusória da relação de dependência, na qual o sujeito sente que tem controle sobre os riscos de uma sustentação e de uma ligação tão fundamental com o ambiente.

Um aspecto relevante destacado por McDougall (1995) é que esse percurso de falhas da relação mãe-bebê, que irá culminar em adicção, também está relacionado com uma condição de dependência vivida pela própria mãe. A autora afirma que tais relacionamentos adictivos têm origem em angústias, temores e desejos maternos, e objetiva encontrar a presença, os cuidados e funções maternas impedidas no passado. Para a au- 
tora, a adicção consiste fundamentalmente em automedicação de estados emocionais de importante sofrimento, que se dá numa perspectiva de cura, do ponto de vista do sujeito.

McDougall (2001) destaca que tais angústias presentes nas adicções podem ser divididas em três categorias em relação à origem: neuróticas, severas e psicóticas. As angústias severas consistem em vivências de morte interna; as psicóticas se vinculam ao risco de fragmentação, vazio e perda de identidade; e as neuróticas, ao conflito psíquico. A autora expõe três maneiras pelas quais o sujeito procura aliviar o sofrimento. A primeira consiste no movimento de evitar angústias neuróticas; a segunda, na busca de conter estados de profunda angústia, que podem se manifestar de maneira paranoide ou depressiva, marcada pelo sentimento de morte interna; a terceira constitui uma tentativa de evitar angústias psicóticas de fragmentação, o terror frente ao vazio, sofrimentos em que a experiência de identidade se torna comprometida. Eis aqui perspectivas de aproximação da constituição da adicção com o fronteiriço, derivações de falhas da dependência inicial do bebê em relação à sustentação do ambiente, que geram caminhos de alívio muito próximos.

Assim, na busca por uma droga ou outro objeto há a esperança de encontrar uma contenção desses estados e falhas, que têm necessariamente o fracasso como destino, pois a solução é repetidamente procurada em elementos exógenos e inanimados que nada podem curar de fato. Segundo a autora (2001, p. 34): “Como nenhum elemento ou objeto pertencente ao mundo real pode reparar as faltas do mundo psíquico interno, o comportamento adictivo tem necessariamente uma dimensão compulsiva".

Tal busca externa de alívio não visa apenas retificar a própria imagem deteriorada, mas também conter e reparar falha parentais. Consiste, portanto, na tentativa desesperada de livrar-se das pressões emocionais insuportáveis e de dependência dos objetos primários fundamentais para a constituição humana, dos quais todo indivíduo precisa depender durante certo período da vida. Nesse sentido, há uma dúvida permanente quanto à presença materna, que se estende para a vida afetiva como um todo, através da descrença relacionada à consistência da sustentação e da permanência das figuras significativas. Nesse caminho, a droga se estabelece como promessa falida, porém ativa do ponto de vista do indivíduo, de independência das figuras parentais e da insubmissão a um ambiente insuficiente e falho. Essa esperança expressa no repúdio à submissão, 
através da droga ou outros objetos, gera, paradoxalmente, o clássico circuito adictivo e seus dolorosos percalços.

Nas palavras da autora, eis o ponto de vista ativo do indivíduo frente à decepção e à ameaça de ligação com os objetos primários: "Você não pode mais me abandonar, agora sou eu que estou no comando" (McDougall, 2001, p. 34). Tal postura frente às relações guarda a esperança de que esse grito de independência traga reparação ao sujeito à beira de perdas brutais e o proteja contra ameaças passadas e futuras.

Torna-se possível relacionar a compreensão da autora sobre a adicção ao sofrimento do fronteiriço, pois é no centro da experiência de dependência como temor e necessidade que esses conceitos se aproximam. Para além das toxicomanias, a autora ultrapassa a referência a um objeto químico e defende a perspectiva de que qualquer objeto posse se constituir como elemento de adicção. Nesse sentido, filia-se à concepção winnicottiana de que esse destino da vida emocional consiste fundamentalmente em patologia da relação com o outro.

Para McDougall (1992), as adicções também são derivadas de falhas na transicionalidade, que culminam com a busca de substituição do objeto transicional e suas funções. Assim, uma nuance importantíssima do olhar da autora para esses fenômenos é que o objeto constituído a partir dessas falhas é tomado como responsável por todos os males e promessas de salvação. O outro, portanto, torna-se o depositário do qual o sujeito irá necessariamente depender, apesar de manobras internas de sobrevivência e controle. Há, nesse ponto, grande proximidade entre o sofrimento fronteiriço e a compreensão da autora acerca da adicção, ambos relacionados à ameaça de perda e de sustentação imputada a um objeto constituído externamente.

Nessa direção, a autora concebe a noção de relação adictiva, na qual o objeto da ligação compulsiva consiste em um outro, uma pessoa tomada como droga, na perspectiva de obturação do vazio, da restauração de falhas do ambiente e promessa de cura. Essa patologia relacional está fundada, para a autora, principalmente no descaminho da transicionalidade:

A fragilidade de um equilíbrio psíquico que depende tanto dos outros - chamemos de relação adictiva - é evidente, a ponto de o indivíduo ignorar o que lhe deve essa criação, que é sua. Essa cena psíquica está efetivamente sob o domínio do desejo infantil e de ser o autor de tudo o que existe (MCDOUGALL, 1992, p. 61). 
A perspectiva ofertada pela conquista do espaço potencial, em um percurso bem-sucedido, produz uma presença no mundo baseada na experiência de criação. Quando o objeto transicional cumpre sua função, ele pode ser esquecido e abandonado (WINNICOTT, 1975). Ou sejá, passa a ser um reles objeto, depois que a criança realiza a fundamental experiência de criação do mundo e de si - eis a vivência paradoxal de criar e encontrar (WINNICOTT, 1971). Esse objeto sintetiza a imagem da mãe, do ambiente, das figuras que estão prestes a ser guardadas como presença interna - nos termos da autora, "introjetadas" - e, portanto, prestes a ser passíveis de figuração e representação.

Humberg (2014), ao abordar a compreensão de McDougall sobre as adicções, observa que a aquisição de uma imagem materna, acessível em sua ausência, não consiste necessariamente em uma identificação simbólica. Em outras palavras, para a criança que ainda não se apropriou da função do ambiente como recurso emocional, o objeto transicional conota a possibilidade de união com a mãe em sua ausência e permite suportar separações. Para McDougall (1992), a palavra "mamãe", como emblema da simbolização e da conquista do percurso da transicionalidade, permite o acesso à figura materna em sua ausência, bem como a lembrança dela.

Quando o ambiente falha e a conquista do espaço potencial não é bemsucedida, são comprometidas não somente a possibilidade de uso desse objeto, mas também a aquisição da simbolização. Desse fracasso decorre um risco de integridade existencial, uma angústia ligada ao sentimento de unidade, capaz de promover a diferenciação entre dentro e fora, $\mathrm{Eu} /$ não-Eu. Com tamanho impedimento e distorção de um desenvolvimento que caminha para a separação, o colapso da transicionalidade (CRUZ, 2012; BOLLAS, 1992), o indivíduo se lançará em busca de objetos substitutivos, capazes de cumprir transitoriamente o recurso que a transicionalidade promoveria como condição, ou seja, como potencialidade emocional do sujeito, e não como função buscada externamente. Com a impossibilidade do uso desse objeto que garante a transição entre o mundo subjetivo e objetivo, assim como a separação gradual da mãe, a criança estará fadada à utilização de um único recurso:

[...] clivar-se em dois, uma parte se fecha sobre o mundo subjetivo interno e outra se vira em direção ao mundo exterior sobre a base de uma adaptação complacente àquilo que é solicitado pelos outros, 
completamente afastada da realidade psíquica íntima. O indivíduo corre o risco de viver daqui em diante como "absolutamente não real", como não compreendendo nada desse mundo, como nada podendo reter - em suma, como "vazio" (MCDOUGALL, 1992, p. 60-61).

Trata-se, portanto, de uma relação adictiva que se apresenta como destino e que pode direcionar-se a diversos objetos - drogas, comida, internet, redes sociais, trabalho ou uma pessoa. No caso de objetos de adicção mais humanizados, como sexo, aparelhos que oferecem contato com um outro, ou propriamente a relação direta com uma pessoa, estes são tomados de forma tragicamente externa, e sua presença não sobrevive ou não permite uma relação nos moldes de alteridade. Uma marca importante desse conceito reside na terminologia. Relação ou relacionamento adictivo diz respeito necessariamente ao entre, a um campo relacional no qual a patologia se estabelece. Assim como Winnicott (1971), a autora aborda a adiç̧ão como sofrimento decorrente de um relacionamento fundante, baseado na experiência de mutualidade, que ao cabo deveria desaguar em duas pessoas distintas e em uma área de experiência transicional, capaz de produzir diferenciação, presença e compartilhamento.

Esses objetos de adicção, portanto, se estabelecem com a missão impossível de substituir os objetos transicionais da infância, que poderiam abrir caminho para uma vida de relativa independência da mãe, mas que não são constituídos como tais ou são destituídos de seu papel. Contudo, tais objetos de adicção se localizam no polo oposto daquilo que o objeto transicional de fato oferece. São incapazes de substituir a mãe, uma pessoa, uma relação de troca, comunicação, mutualidade e constância no tempo - e por isso produzem uma modalidade de escravidão. Adicção, portanto, segundo a autora, diz respeito muito mais a uma presença somática, da ordem da intensidade, do que a uma conquista psíquica como encontro de uma relação com o próprio Self ou com o mundo. Vincula-se a objetos transitórios, sempre localizados do lado de fora e desesperadamente procurados para remendar funções fundamentais da vida humana, presença, compartilhamento e criação (MCDOUGALL, 1992).

Tal modo de relação objetal, próprio da adicção, permite uma aproximação com o fronteiriço, ambos como patologias na constituição de objetos e fenômenos transicionais. Nas relações adictivas, assim como no paciente fronteiriço, na direção oposta do que se dá na transicionalidade, o povoamento objetal da vida do sujeito ocorre pre- 
dominantemente por objetos transitórios e externos, sejam drogas, sejam pessoas. O objeto da adicção, assim como o objeto vacilante do fronteiriço, um outro-coisa, constitui esperança de cumprimento da função transicional e de retificação das falhas do Self. Trata-se da dependência do objeto externo, vivido como vital, que carrega a missão de promover a experiência de estar vivo, ser real e autêntico (MCDOUGALL, 1992).

\subsubsection{Outros autores da psicanálise contemporânea}

Outros autores da psicanálise contemporânea têm se ocupado, direta ou indiretamente, da relação entre estados fronteiriços e adicções, especialmente toxicomanias. De formas distintas, destacam-se os trabalhos de Audibert (2008), Chabert e Verdon (2008), Chabert (2009, 1999), Le Poulichet (2005), Chauvet (2004), Brusset (2004), assim como de Freire (2006), Miel (2002) e Sztulman (1997).

Os autores mencionados apresentam semelhanças entre diferentes realidades psíquicas, a existência de um circuito repetitivo, que dirige toda a libido à tentativa de sanar o sofrimento corporal. Relacionam a toxicomania a um modo de automedicação paradoxal, e não apenas a um movimento de autodestruição. A droga funciona como uma tentativa de alívio de um sofrimento intolerável. É como se a própria presença do corpo e do pensamento se tornassem insuportáveis, como se houvesse um prejuízo ou doença que unicamente fossem aliviados na busca de restauração desse corpo, mediante tratamento sempre idêntico.

Tais condutas adictivas - direcionadas a um produto, a uma situação ou a um objeto - se vinculam a uma falência traumática do ambiente primitivo e se caracterizam como uma falha de simbolização. Expressam-se por uma dependência da realidade do objeto externo, vinculadas ao recurso de defesas primitivas, como incorporação, projeção, clivagem, idealização e onipotência, concepções muito próximas da compreensão dos pacientes fronteiriços. A procura desesperada por objetos de consumo se dá num precário equilíbrio entre a necessidade de objeto e uma proteção narcísica, contexto que estabelece uma separação impossível de ser elaborada como perda por conta de sua crucial função narcísica (AUDIBERT, 2008; LE POULICHET, 2005; CHAUVET, 2004).

Brusset (2004) também associa o fronteiriço à adicção, explicada pelos problemas de identidade, pelo falso Self adaptativo, dificuldades de relação afetiva, depres- 
sividade, angústia, vazio, variedade e ineficácia dos mecanismos de defesa, que não poupam o sujeito da angústia, do desespero e do desamparo. $\mathrm{O}$ autor compreende que as adicções não se constituem através de recalcamento ou busca substitutiva, mas consistem em um circuito de gozo e sofrimento que retira os investimentos e ganham protagonismo na dinâmica psíquica, que se torna progressivamente empobrecida.

Nesse percurso, o sujeito se torna mais dependente do objeto à medida que suprime todos os laços da dependência afetiva. Trata-se, portanto, do caminho polissêmico de domínio do objeto, de vingança, esperança de encontro e liberdade. Os pontos de vista de Brusset (2004) e Chauvet (2004) coincidem, pois postulam que a adicção funciona como uma busca de libertação da dependência afetiva, frente aos objetos internos e externos, e leva a outro tipo de dependência, que a substitui e reforça paradoxalmente.

Chabert (1999) contribui com vasta pesquisa sobre o fronteiriço. A autora nomeia esse fenômeno clínico de "funcionamento limite" e o compreende como uma organização, uma manifestação não estrutural, fundamentalmente baseada na hipótese de uma incapacidade grave de uso do objeto. Chabert funda seu olhar em uma composição psicopatológica marcada por elementos psicóticos e neuróticos, porém focaliza a angústia de perda do objeto e o impedimento do seu uso como referências diagnósticas principais. Para a autora, todo ser humano vive, em algum ponto de seu desenvolvimento, a angústia de perda objetal. Contudo, nem todos sofrem uma importante consequência: a impossibilidade de retenção desse objeto internamente. Tal incapacidade deriva de uma articulação complexa entre investimentos narcísicos de autoconservação e objetais (CHABERT, 2009).

A partir de referências freudianas, a autora caminha para a adoção do objeto transicional - no sentido de mediador entre o Eu e o objeto -, como eixo conceitual fundamental da patologia limítrofe. Baseia-se na concepção de que o acesso à transicionalidade se torna precário no funcionamento limite em graus que podem variar. Esses impasses na constituição do objeto transicional e do espaço intermediário são entendidos, principalmente, como consequência da ameaça e da desconfiança de que o objeto sobreviva à destruição por parte do sujeito. Isso porque os danos na construção do espaço potencial geram importantes entraves para a constituição dos objetos e a relação do sujeito com estes (CHABERT, 2009). 
Para Chabert (2009), Audibert (2008), Le Poulichet (2005) e Chauvet (2004), a consequência dessa impossibilidade de transicionalidade culmina em comprometimento da referência de alteridade para o indivíduo. Como a construção do Self e do outro se dão de modo relacional e interdependente, um empecilho na constituição do objeto, como um outro, implica necessariamente em empecilho para a integração e o amadurecimento do Self. Desse processo decorre uma ausência objetal concomitante à fragmentação do $\mathrm{Eu}$, no qual os recursos para separação e retenção do outro não estão disponíveis. Eis o drama central dessa patologia, em que a perda do outro se iguala à perda de si. Frente a esse cenário, a perda se torna um horizonte impossível e insuportável, e o fronteiriço se rende à submissão à realidade externa como defesa.

Chabert (2009) destaca que o contato com a realidade externa se torna extremamente caro para o fronteiriço, que esconde e tampona seu vazio justamente ao lançarse nela. Assim, os recursos que deveriam estar disponíveis internamente, ou no espaço intermediário, localizam-se fora. Trata-se, portanto, de uma dependência brutal do mundo externo. Em contrapartida, diante da constatação de que o objeto não responde à salvação e à sustentação narcísica, ele será imediatamente abandonado e deixará de receber investimento afetivo. A autora chama a atenção para a alternância entre a dependência extrema do externo e o abandono ativo do objeto não responsivo, nesse dramático desarranjo da transicionalidade, da relação $\mathrm{Eu} /$ não-Eu, dos mundos subjetiva e objetivamente percebidos. Há aqui uma correlação evidente entre a dinâmica da adicção e do fronteiriço, sobretudo na adesão a um objeto externo vital que pode ser consumido e abandonado, procurado como alívio passageiro de angústias aterrorizantes.

Sobre tal experiência de ausência interna devastadora, destacam-se as vicissitudes da perda do objeto e suas consequências sobre a capacidade do paciente fronteiriço de experimentar a presença e a constância de objetos e de representações internas. Em tais condições, a vivência da ausência e a falha do objeto não encontram recursos de elaboração ou luto. Resulta uma experiência de vazio e perda de sentido pela impossibilidade de significação da perda. Outro aspecto importante consiste em falha na ligação entre afetos e representações nos processos de interiorização(CHABERT, 2009).

Trata-se de impedimento na capacidade de reconhecer estados afetivos, discriminar emoções básicas como boas ou ruins, prazerosas ou desprazerosas. Impossibilidade que decorre do contato com um objeto etéreo, paradoxalmente presente por sua 
ausência. Evidencia-se nessa dinâmica, portanto, uma fragilidade do contato do fronteiriço com sua vida interna. Como compensação de tal despovoamento interno, há um hiperinvestimento na realidade externa, nos moldes de uma grave dependência e submissão que desconsideram os traços do outro. Esperança radical que pode levar o sujeito à adesão a diversos objetos, nos quais a adicção apresenta-se como destino (CHABERT; VERDON, 2008; CHABERT, 1999).

Gurfinkel (2011, 2001), Freire (2006), Miel (2002) e Sztulman (1999) apontam a toxicomania como patologia do vínculo objetal, muito próxima da dinâmica do fronteiriço. Tais autores contemporâneos também abordam essa relação a partir dos descaminhos da transicionalidade, e destacam que a construção do espaço potencial também depende da presença suficientemente boa do objeto externo. Assim, o objeto transicional falha, se torna inconsistente e não realiza a função de defesa contra a angústia depressiva. Desse processo decorre a impossibilidade de introjeção da função materna e da capacidade de contenção de intensidades afetivas e pulsionais.

A busca por uma substância, como desdobramento dessas falhas, leva a uma falência da construção de um registro fantasmal, onírico, simbólico, nos moldes do que Gurfinkel (2001) conceitualizou como "colapso do sonhar" e a consequente impossibilidade de internalização objetal. Miel (2002) oferece interessantes exemplos de situações clínicas em que a droga é tingida por uma aura transicional, como no caso de pacientes que não mais precisam ou buscam a droga, mas se mantêm nesse circuito principalmente pelo ritual envolvido. O autor destaca que a falha na aquisição e no uso do objeto transicional impede a constituição do objeto interno, que desse modo não atinge o estatuto de objeto de desejo. Assim, tais objetos se constroem internamente como objetos narcísicos, marcados por intensidades perceptivas, sensoriais e emocionais. Miel frisa a consequência de um modo de relação utilitarista com os objetos no caso da toxicomania, aspecto próximo dos pacientes fronteiriços.

Freire (2006) ressalta que a compulsão ao uso de substâncias não consiste necessariamente em toxicomania e estabelece divisão em diferentes categorias de uso de drogas, conforme a organização mental do paciente. Relaciona as adicções a níveis mais primitivos de organização, em que o Eu, apesar de minimamente diferenciado, não se desenvolveu satisfatoriamente, e o uso compulsivo de um objeto pode estar relacionado 
a uma função adictiva nos transtornos narcísicos, por exemplo. De qualquer modo, também pode conter o sentido simbólico de um sintoma.

Portanto, a autora (FREIRE, 2006) considera necessário reconhecer o tipo de objeto, o nível de simbolização e a angústia presentes em cada caso. Ela localiza a toxicomania como psicopatologia pré-genital, anterior à constituição do Eu, portanto anterior ao complexo de Édipo. Destaca a primazia do processo primário e da satisfação imediata, em que a descarga pulsional e a passagem ao ato predominam. Assim, a perspectiva de adiamento da satisfação, sem a mediação do processo secundário, leva o sujeito à ação e à impossibilidade de simbolização. Freire sugere, ainda, que a compulsão por substâncias se aproxima de uma constituição semelhante a uma estrutura, aspecto importante para a presente pesquisa.

Características como mecanismos de defesa, o tipo de angústia e a dinâmica pulsional também são aspectos compartilhados por pacientes fronteiriços e toxicômanos, segundo Sztulman (1999), que, entretanto, não indica a existência de uma personalidade propriamente toxicomaníaca. Aponta, nessas manifestações psicopatológicas, angústias de perda do objeto, de abandono e de distanciamento; conflito entre o Eu e o Ideal de Eu; predomínio de relações objetais do tipo anaclítico; proeminência de mecanismos de defesa como identificação projetiva, clivagem do objeto, negação e a díade idealização-desvalorização.

A partir desse painel e dessas referências sobre a adicção em pacientes toxicômanos e fronteiriços, é possível reunir características frequentemente destacadas na literatura, entre elas, a incapacidade de pensar, refletir e adiar, bem como a substituição desses recursos pela ação. Constata-se que tais pessoas são sensíveis às tensões decorrentes das necessidades, porém se mostram incapazes de transformá-las em termos verbais para satisfazê-las. Só conseguem se livrar de seu desconforto através da ação. A evitação do pensamento e a impulsividade relacionam-se ao vazio existencial e objetal, com o qual não podem se deparar por conta da fragilidade de sua constituição emocional. Apresentam comportamentos radicais, do tipo "tudo ou nada", e buscam a todo momento um objeto mágico para amenizar sua angústia.

Sobretudo, torna-se importante destacar que a dependência ao outro nos pacientes fronteiriços sempre compareceu de forma periférica nos textos psicanalíticos, porém o aspecto adictivo permeou as entrelinhas sem o devido destaque. Desde os desti- 
nos da angústia de perda de objeto (GREEN, 2000; KERNBERG, 1995, 1991; BERGERET, 1996, 1991; AUDIBERT, 2008; LE POULICHET, 2005; BRUSSET, 2004; CHAUVET, 2004) como referência central na psicopatologia desse quadro, a relação anaclítica (BERGERET, 1996, 1991), o colapso da transicionalidade (MCDOUGALL, 2004, 1992; WINNICOTT, 1975) e a consequente vaguidão do outro na vida emocional do sujeito, assim como o comprometimento da capacidade simbólica (CHABERT, 2009; AUDIBERT, 2008; LE POULICHET, 2005; CHAUVET, 2004; MCDOUGALL, 1992), compõem referências muito próximas de um estado de adicção, cuja compulsão na direção do um objeto-outro, sempre necessário e impermanente, torna-se um meio de vida.

\subsection{DELÍRIO, ESPERANÇA, TRANSFORMAÇÃO: APROXIMAÇÕES ENTRE O FRONTEIRIÇO E A ADICÇÃO}

As características comumente elencadas como próprias do fronteiriço, sobretudo a necessidade e a busca desesperadas por um objeto externo, a identidade frágil, o vazio e a hipertrofia da ação (GURFINKEL, 2011, 2008; BERGERET, 1998; GREEN, 1988b), podem indicar uma dependência fundante do outro, que se dá nos moldes da adicção a uma droga. São estados emocionais em que a pessoa vive uma espécie de delírio relacional de ausência e abandono, no qual a perda do outro se apresenta como verdade e destino, independentemente de um acontecimento concreto na vida atual do sujeito. Tal dependência, com importante perda de contato com uma suposta realidade, marca central desse sofrimento, abre margem de questionamento sobre esse componente.

Nesse sentido, nos pacientes fronteiriços constata-se uma problemática relacionada à construção da alteridade (CARDOSO, 2007), da complexa relação entre interioridade e exterioridade, da permanência de objeto, de sua constância e consistência. Nessa psicopatologia, tanto do fronteiriço como da adicção, percebe-se um desatino na busca por um objeto vital porém vago, cuja existência aparenta ser paradoxalmente desacreditada. Trata-se de uma servidão ao outro, própria dessa condição fronteiriça (CARDOSO, 2005), um outro prestes a se desfazer, constituído como uma aposta de restituição e encontro sem traços claros. 
Diferentemente da descrição psicopatológica desse quadro recorrente na literatura (KERNBERG, 2006, 1995a, 1995b, 1991; GABBARD, 1998; KAPLAN et al., 1997), o teste de realidade preservado nesses pacientes parece carregar uma contradição fundamental. Há uma perda importante de contato com a realidade no que se refere à ligação com o outro e sua presença (STERN, 1938/1986). A ameaça de perda do objeto, sua inconstância, sua dimensão vaga e a angústia que disso decorre revelam um contato com o ambiente marcado pela distorção advinda de referências que tingem o mundo de ameaça e medo do colapso. É o reconhecimento dessa espécie de delírio relacional e da angústia de perda do objeto que abre espaço para o desenvolvimento da presente pesquisa.

Nessa perspectiva, destaca-se um estado contínuo de desconfiança, uma verdade da vida baseada em falhas iniciais que tingem o destino do indivíduo com tons paranoides, porém não nos moldes de um delírio estruturado, mas como um clima que perpassa a vida sem figuração ou símbolo. Esse delírio relacional leva a uma busca compulsiva pelo outro - que, entretanto, sempre escapa, inapreensível. Nessa tentativa de manutenção e restituição de objetos assustadoramente impermanente, configura-se uma adicção, uma dependência ao outro, a qual condena o sujeito a uma relação desesperada de consumo, de adesão maciça ao objeto, e o impede, em geral, de ter uma experiência completa (WINNICOTT, 1975).

Nesse contexto de importância radical do objeto para o sujeito, a adicção, que em sua raiz etimológica se vincula à escavidão, passa de desejo para necessidade (MCDOUGALL, 1997). Em um consumo compulsivo e irrefreável de objeto específico, a pessoa experimenta forte impulso ao uso e incapacidade de evitá-lo (GURFINKEL, 2011, 2001, 1995). O processo adictivo, assim, eleva o objeto ao estatuto de fonte de alívio exclusivo e necessário. Segundo Gurfinkel (2011), o termo neonecessidade, criado por Denise Braunschweig e Michel Fain, revela que o uso do objeto torna-se para o adicto uma nova necessidade vital, como água, ar, alimento etc. Portanto, a pessoa perde sua liberdade de escolha nesse circuito de escravidão.

Uma característica que deve ser destacada é que a adicção sempre guarda uma singularidade, não só porque as biografias são únicas, mas porque cada manifestação adictiva contém uma especificidade ligada ao objeto eleito, mais ou menos humanizado. Certos objetos carregam um potencial adictivo em si, por conta de sua ação no sistema 
nervoso central e, nesse caso, cada substância também determinará um estado psíquico próprio a ser buscado. Da anestesia nirvânica até a aceleração maníaca, estados de suspenção e ausência ou povoamentos alucinatórios, as drogas e seus efeitos sobre o corpo agem de forma entrecruzada na complexa relação entre psique-soma, ambiente e história pessoal (CRUZ, 2012).

Para além das drogas psicoativas, que no senso comum carregam consigo a imagem de adicção mais presente na cultura, há ligações compulsivas com jogos, compras, videogames, comida, sexo, internet, trabalho ou uma ampla e variável gama de elementos presentes na vida humana. Longe de uma substância exógena, elementos como os mencionados fazem ver o componente subjetivo presente na adicção de forma patente. Por exemplo, adicções à internet e às redes sociais, que enclausuram pessoas e as isolam dos encontros presenciais, podem também indicar uma procura por um outro narcisicamente ideal, um outro-ninguém, mas que é irrefreavelmente esperado e ganha importância central na busca por alívio de uma angústia de ausência do objeto, além de uma frágil sustentação da existência. (GURFINKEL, 2011; GUERRESCHI, 2007; FUKS, 2000).

Qualquer objeto pode se prestar a uma adicção. Partindo de Winnicott (1971), Gurfinkel (2011) destaca que a adicção não é definida pelo objeto usado, mas sim pelo uso que se faz dele, concepção fundamental para as construções aqui propostas. Em termos classificatórios, as adicções podem ocorrer tanto nas neuroses, psicoses e perversões, como nos estados-limite, pois em si não constituem uma estrutura (GURFINKEL, 2011). Porém, diferentemente da adicção em um estado neurótico ou psicótico, no fronteiriço há uma busca desesperada por um objeto como forma de sobrevivência psíquica e emocional, através de relações adictivas (MCDOUGALL,1992). Dentro das diversas possibilidades de manifestação de uma adicção, será focalizado no presente estudo um tipo em particular, a adicção ao outro, condição central no sofrimento dos pacientes fronteiriços (CRUZ, 2012).

Ao destacar essa forma específica de relação com objetos, principalmente quando se trata do objeto-outro, uma pessoa, torna-se importante frisar que esse não é um objeto qualquer. Não consiste em uma coisa, algo inanimado como uma pedra de crack, uma máquina de videopôquer, uma bolsa de grife ou um alimento. De qualquer forma, a relação de adicção a outra pessoa carrega a trágica marca de coisificação do 
objeto buscado (GURFINKEL, 2011) e o aproxima do estatuto de coisa esvaziada de subjetividade.

Todos os seres humanos estão destinados a se ligar a uma pessoa e dela depender para se constituir (WINNICOTT, 1963) - um ambiente favorável ao desenvolvimento oferecerá resposta e sustentação a essa condição inerente a todos nós, ao passo que um ambiente desfavorável provocará uma série de entraves e impedimentos. É, portanto, fundamental distinguir o medo de perder o outro, próprio da vida humana regular, da compulsão ao outro. Esta última diz respeito a uma reação a uma falha importante no caminho da constituição de uma pessoa, na travessia que vai da dependência rumo à independência. Esse percurso pode ser marcado pela impossibilidade de construção de recursos fundamentais para lidar com a alteridade, a experiência de perda e a transitoriedade dos vínculos. Consiste em impedimentos que lançam o sujeito na busca desesperada por apoio anaclítico (BERGERET, 1998, 1991), por um outro, e que configuram um modo particular de relação objetal. Nesse sentido, segundo Bollas (1992, p.170), o sujeito sente que sua vida "está no objeto".

De qualquer forma, esse aspecto dramático presente nos fronteiriços, ou seja, a experiência desestruturante de ausência e vazio, a angústia pelo desaparecimento do outro, a reação extrema pela perda imaginada ou concreta, são dores essencialmente humanas que todos podem experimentar. Segundo Hegemberg (2000), esses pacientes vivem uma angústia radicalmente humana, dores comuns a muitos, porém ampliadas, como se estivessem sob uma lente de aumento.

Esse tipo de adesão e busca pelo outro revela impossibilidade de luto e de elaboração da perda, estado próximo da melancolia. Todavia, distante da presença de objeto, que é evidente no melancólico (FREUD, 1917/1996; KLEIN, 1940/1994; LOEWALD, 1962/1994; JACOBSON, 1965/1994), nas relações adictivas não há uma identificação com o objeto perdido para retê-lo internamente, mas uma vivência de perda radical, na qual a dimensão singular do objeto se torna vaga (CRUZ; TARDIVO, 2013; CRUZ, 2012). Como a ausência não pode ser vivida como privação ou destruição de um objeto, o trabalho de luto, assim como de elaboração e separação, torna-se impossível, de modo que a perda atinge o sentimento de si e a "continuidade do ser". No drama exposto por essa forma de relação "não é a sombra do objeto (FREUD, 1917/1996) que cai sobre o Ego, mas a sombra do vazio" (CRUZ, 2012, p. 116). 
Nesse sentido, para a compreensão do fronteiriço, Gutton (1986) estabelece uma discriminação entre afeto depressivo e depressividade. Compreende a depressividade como possibilidade de sentir o afeto depressivo relacionado ao objeto ausente, vivido como perdido. Tal estado de depressividade tem a marca de não comportar o recurso representacional. Portanto, impede o sujeito de encontrar objetos substitutivos que aplaquem sua angústia e a disponibilidade do recurso de elaboração da perda, como no caso do fronteiriço e das adicções. Daí a busca por objetos substitutos idealizados e a consequente adesão a esses objetos, com os quais a vivência de perda não ocorre.

Na perspectiva do afeto depressivo, em contraposição, o indivíduo pode se apoiar em presenças internas pensáveis, estáveis e acessíveis. Nos estados de depressividade, por sua vez, o sujeito tende a buscar projetivamente tal apoio no outro ou no próprio corpo, como no caso da busca pela droga. Gutton (1986) apresenta o conceito de depressividade como estado emocional fundante das toxicomanias, e a descrição do autor aponta para importante proximidade com a dinâmica dos pacientes fronteiriços.

Trata-se, portanto, de um circuito de dor pela ausência de um objeto que não pôde ganhar consistência representacional ou luto pela perda, em que há uma ameaça permanente de desestruturação desse indivíduo diminuído e dependente, reativo por conta de um ódio secundário à impermanência do objeto, experimentado como vital, grandioso, esvaziado de pessoalidade e, portanto, inalcançável. Essa condição marca a impossibilidade de uso do objeto (WINNICOTT, 1969) e a perpetuação de uma adicção ao outro, mais ou menos coisificado. Segundo Gurfinkel (2011), essa é uma forma de relação marcada pela devoção e devoração do objeto, porém um objeto inconsistente para os pacientes fronteiriços.

Winnicott (1969) ocupou-se do desenvolvimento e estabelecimento da capacidade de usar objetos, a partir da sustentação do ambiente. Essa capacidade não está dada, é uma aquisição do amadurecimento emocional e envolve um objeto necessariamente real, ou seja, um objeto integrante da realidade compartilhada, e não apenas um feixe de projeções. Segundo o autor, a destruição desempenha um papel central na criação da realidade, na qualidade de externalidade do objeto. Essa destruição é potencial, diferentemente da aniquilação, que significa ausência de esperança.

Essa experiência depende da capacidade do objeto de sobreviver, não retaliar e, assim, sair dos limites do subjetivo, da área do controle onipotente, adquirindo uma 
existência compartilhada. Segundo Winnicott (1969, p. 130): "Não há raiva na destruição do objeto a que me refiro, embora se possa dizer que existe alegria pela sobrevivência [dele]”. O objeto está sempre sendo destruído na fantasia, e essa qualidade permite o sentimento de realidade do objeto sobrevivente, além de contribuir para sua constância. A partir desse ponto o objeto pode ser usado.

$\mathrm{O}$ ato de se relacionar pode ser descrito em termos do sujeito individual, pode se dar com um objeto subjetivo. Já o uso necessita da aceitação de sua existência, o objeto precisa ganhar o estatuto de fazer parte da realidade externa. A expressão "uso de objeto" diz respeito à capacidade do paciente de colocar o analista fora dos fenômenos subjetivos; o que está em jogo, portanto, é a capacidade do paciente de usar o analista. Para Winnicott (1969), essa é a diferença entre relacionar-se com um objeto e usá-lo. O autor destaca a importância de levar em consideração a natureza do objeto e o meio ambiente, não como mecanismos projetivos, mas como entidade com existência própria e concreta.

O paciente fronteiriço padece da impossibilidade de uso do objeto, que não adquire externalidade e qualidades próprias, permanecendo como fenômeno subjetivo. $\mathrm{O}$ outro não pode ser usado, pois não adquiriu a capacidade de ser presença na ausência, por conta de falhas na constituição da transicionalidade e consequentemente na capacidade de simbolização (CRUZ; TARDIVO, 2013; CRUZ, 2012; BRUSSET, 2004; CHAUVET, 2004). O fronteiriço, portanto, permanece em constante busca pelo controle onipotente do objeto, que, no entanto, sempre lhe escapa (WINNICOTT, 1969).

Por conta disso, o conceito de relação adictiva, criado por McDougall (1992), torna-se relevante nesse contexto. Diz respeito à adicção a um outro, com o qual se estabelece uma ligação compulsiva. Constitui um modo patológico de relação, que consiste na dependência de uma presença que assegure a sustentação precária de um Self à beira de um colapso e o proteja de um estado de solidão disruptiva.

Essa forma de dependência patológica ao outro pode ser confundida com uma perversão, pela violência na relação e pela impossibilidade de reconhecimento da alteridade e da totalidade do objeto. Também pode ser confundida com um tipo de caráter (FREUD, 1931), por um suposto destino específico da vida pulsional (GURFINKEL, 2011). No caso das relações adictivas, consideradas a partir do fronteiriço, não há necessariamente uma sexualidade de caráter perverso, parcializada, dissociada e excessiva. 
Essa dependência consiste em patologia marcada pela angústia de perda do objeto, terreno habitado por necessidades muito mais do que desejos, ou seja, a ligação aqui discutida não se funda em caminhos pulsionais como referência predominante. Trata-se de uma patologia relacional (GREEMBERG; MITCHELL, 1994), na qual o ser, e não o ter, está ameaçado.

Essa contribuição auxilia no levantamento da hipótese do componente adictivo presente no sofrimento dos pacientes borderline. Neste trabalho, o foco será dado ao fronteiriço, cuja abertura e ação se concentram em um lançar-se em busca de um outro "salva vidas", mais distante de estados marcados por uma configuração esquizoide. No drama vivido por esses pacientes, predomina um dos dois polos próprios da psicopatologia dos estados fronteiriços (FIGUEIREDO, 2003), ou seja, o polo narcisista em detrimento do esquizoide. Nesse caso específico, ocorre a procura maciça por um objeto idealizado, promessa de preenchimento id́lico por um outro esvaziado de traços próprios, que marca a natureza do "encontro" com esse outro-subjetivo, capaz de ocupar tal lugar.

Gurfinkel (2011) destaca uma condição de paixão adictiva, de caráter narcisista, alimentada pela necessidade de sustentação de um ideal que o Eu não sente ser capaz de alcançar. Há grande precariedade do amor-próprio e, diante da perda do objeto, o reinvestimento em outros objetos e no mundo fica bastante reduzido. Na adicção, podese perceber um precário equilíbrio entre investimento no objeto e investimento no Eu, em que o indivíduo fica destroçado e esvaziado pela paixão adictiva ao objeto. Porém, no contexto do fronteiriço, não se trata somente de perda do amor-próprio, mas da grave fragilidade de um Self minimamente íntegro e da impossibilidade de sentir-se vivo e real diante dessa ausência.

A falta de um objeto vivo, presente e real - substituído por um objeto no qual ausência e presença se alternam de forma imprevisível e assustadora - impede que um Self suficientemente integrado se constitua. Nesses casos, o Self pode ficar congelado pelo olhar de uma mãe "morta ou morta-viva", uma mãe-zumbi ou mãe-fantasma, que expressa a falha radical vivida nessas condições. Há e não há alguém ali para ser usado e responder com a receptividade necessária de um rosto humano vivo e interessado. Trata-se da falha de presença e consistência de um objeto vitalizado e integrado, que 
possa ser ofertado no caminho da constituição de um Self (GREEN, 1988; MCDOUGALL, 1992; WINNICOTT, 1971, 1969).

$\mathrm{Na}$ vida relacional do paciente fronteiriço, é instável a ligação com o outro, por vezes experimentado como excessivo e com presença insuportável, outras vezes ausente e demasiadamente distante, muito idealizado e grandioso ou muito desvalorizado e depreciado. Esse processo se dá em decorrência da inconstância vivida pelo fronteiriço na relação precoce com a mãe (MCDOUGALL, 1992; FIGUEIREDO, 2003). Tal inconstância promove uma perturbação na transição da relação fusional, de indiferenciação, para o estádio em que o bebê vai aos poucos conquistando a capacidade de discriminar dentro e fora, $\mathrm{Eu} /$ não-Eu. Essas falhas ambientais conduzem a uma fragilidade, do ponto de vista emocional, e podem levar a pessoa em constituição a uma excessiva dependência da presença da mãe ou do outro, problemas na personalização, ou seja, a experiência de habitar o próprio corpo, cisões que ocorrem internamente ou, de forma mais radical, na ruptura da integridade psicossomática (WINNICOTT, 1971; GREEN, 2000; AUDIBERT, 2008; LE POULICHET, 2005; BRUSSET, 2004; CHAUVET, 2004).

O exame dos pensamentos de Winnicott, McDougall, Gurfinkel e demais autores apresentados possibilita a compreensão de que os fronteiriços-adictos vivenciam uma falha na transicionalidade, um colapso no registro da experiência intermediária, na possibilidade de abrigar, reter, criar e encontrar o outro. Ou seja, a ausência do "entre" e a dificuldade de trânsito pelos limites Eu / não-Eu prejudicam a constituição do Self, que, fragilizado, não consegue preencher o vazio com fenômenos e objetos transicionais (WINNICOTT, 1975).

Essa compreensão da psicopatologia do fronteiriço-adicto, iniciada na pesquisa de mestrado de Cruz (2012), indica fracasso da transicionalidade e expõe o componente adictivo presente na busca pelo outro quando a possibilidade de luto, introjeção e identificação estão comprometidas. Nesses pacientes ocorre falência da mediação simbólica e transicional, o que impede a experiência de presença do outro em sua ausência e leva o fronteiriço a um agir compulsivo na busca desesperada por objetos que possam funcionar como recurso vital e precariamente tranquilizador. Cruz (2012) conclui que essa forma de se relacionar com o outro gera uma dependência do externo, como uma tentativa de introjeção e incorporação constante que nunca se completa. 
É a constituição e o uso do objeto transicional que permitem vivenciar a mãe como presente e ausente ao mesmo tempo. A conquista dessa capacidade contribui para a condição da criança de abrigar as ambivalências de uma relação. Em outra direção, falhas na relação mãe-bebê prejudicam a transição da criança de um estado em que está indiferenciada para outro, no qual a experiência de separação se torna possível (HUMBERG, 2014). Essa condição relacional perturbada se traduz em grande turbulência "tudo ou nada", com atuações violentas e uma organização que pode gerar um Eu grandioso ou enfraquecido e diminuído, com oscilações afetivas e pulsionais (FIGUEIREDO, 2003). Tal dificuldade pode ser compreendida como origem do sofrimento fronteiriço em se relacionar com o outro.

Essa perturbação impede que representações, simbolizações e relações intersubjetivas sejam inauguradas. A impossibilidade de transição de um estado indiferenciado para outro de separação prejudica a constituição do espaço potencial, com a importante consequência do colapso da simbolização. Essa incapacidade de simbolização impede o Eu de se separar dos objetos, principalmente dos primários, tornando o sujeito escravo da angústia de perda ou de ser tomado pela presença excessiva do outro. A perda do objeto primário, assim como a incapacidade de habitar o espaço intermediário da experiência humana, podem levar essa pessoa a viver uma descontinuidade de seu existir, resultando na incapacidade de estar só (WINNICOTT, 1982).

Winnicott $(1958$, p. 32) apresenta um elemento importante do amadurecimento emocional, que denominou capacidade para estar só, cuja base é um paradoxo: é a capacidade de estar só na presença de alguém. $\mathrm{O}$ autor menciona que estar só na presença de alguém é uma experiência própria da saúde, pois depende da existência de um objeto bom na realidade psíquica do indivíduo. É uma sofisticação que supõe a integração em uma unidade, a constituição do estatuto de "eu sou", porque existe um ambiente que é protetor. Trata-se de uma sustentação e de uma presença devotada, não invasiva e ao mesmo tempo significativa, que permite à criança criar e encontrar uma vida pessoal e viver experiências sentidas como reais. Essa capacidade pode ocorrer em um:

[...] estágio bem precoce, quando a imaturidade do Ego é naturalmente compensada pelo apoio do Ego da mãe. À medida que o tempo passa o indivíduo introjeta o Ego auxiliar da mãe e dessa maneira se torna capaz de estar só sem apoio frequente da mãe ou de um símbolo da mãe (WINNICOTT, 1958, p. 34). 
Essa presença materna e a consequente experiência de cuidado internalizado, herança fundamental no caminho da constituição de uma pessoa, possibilitam a base para uma diferenciação Eu / não-Eu e permitem estar em um estado de não integração, devanear, ou o que no adulto é conhecido como relaxamento. Este consiste em uma aquisição: quando o amadurecimento emocional segue suficientemente bem, o individuo adquire a capacidade de gradualmente abrir mão da presença real da mãe ou de figura análoga. Nos estados fronteiriços, é marcante a falha nessa capacidade e em suas decorrentes conquistas (GREEN, 2000; AUDIBERT, 2008; LE POULICHET, 2005; BRUSSET, 2004; CHAUVET, 2004).

Humberg (2014) apresenta um relevante aporte sobre a incapacidade do adicto de estar só, condição que remete à impotência, à desintegração e à morte, conforme Kalina (1999). Segue a compreensão do autor argentino sobre essa impossibilidade:

O dependente não suporta a solidão justamente porque, nela, fica sem apoio, ou melhor, porque na solidão volta a experimentar a insuficiência do apoio recebido quando era criança. Esse reencontro com o ausente (os afetos) tem para o dependente o efeito de uma catástrofe. $\mathrm{O}$ fato de a solidão equivaler à vivência de morte deve-se, precisamente, a isto: a solidão adquire o caráter de uma experiência na qual o dependente se percebe vazio, isto é, [entra em contato com] sua inconsistência. Trata-se de um sentimento de impotência irreversível, na medida em que, dominado por ele, o dependente não tem a que ou a quem recorrer para suportá-lo e, muito menos ainda para superá-lo. Assim o ato drogadictivo pode ser visto como uma prevenção: o dependente o realiza para evitar que se manifeste, com toda sua contundência, a experiência desintegradora da solidão-morte. Paradoxalmente, consumando este ato de maneira sistemática (isto é, claramente adictiva), vê-se favorecida a irrupção da definitiva aniquilação (KALINA et al., 1999, p. 34).

Para discriminar entre o normal e o patológico, Audibert (2008) toma como eixo compreensivo a capacidade para estar só, de Winnicott, e considera a falha nessa aquisição como elemento central das adicções. A contribuição original da autora reside no reconhecimento da patologia do estar só, na qual a solidão é vivida como mortífera e disruptiva. A incapacidade para estar só é uma marca de ausência radical, oposta ao estar só na presença de alguém, necessária para a construção dessa capacidade. 
Para Audibert (2008), a dependência em relação ao objeto, qualquer que seja, remete o sujeito à primeira dependência, suscitando uma procura desesperada por independência. A adicção a uma substância é compreendida pela autora como tentativa de viver sem o outro, uma vez que a alteridade é experimentada como insuportável. Tratase de um paradoxo da adicção, no qual se instala uma dependência de um objeto externo e inanimado, na tentativa de não depender de alguém.

Alguns pais se fazem presentes na vida dos filhos de forma invasiva, excessivamente angustiante, estimulante ou excitante, impedindo-os de viver estados necessários de solidão. Assim, conclui Audibert (2008), as crianças passam a ter a nefasta função inconsciente de evitar a solidão dos pais. É importante salientar que a autora apresenta sua elaboração teórica a partir de objetos inanimados de adicção e não faz referência direta aos estados fronteiriços. Porém oferece pistas importantes para essa relação, apesar de destacar, prioritariamente, o componente da invasão e a defesa contra ela, como o mais traumático e determinante, em detrimento da ausência e do vazio.

Essa concepção de Audibert, baseada principalmente nas toxicomanias, enfatiza o fenômeno da coisificação do objeto (GURFINKEL, 2001), sem mencionar o termo. Tal processo de coisificação pode ser extremo e culminar em predominância de objetocoisa como presença central na vida da pessoa. O mundo torna-se pedra, pó, erva, preenchimentos-coisa que organizam a órbita de relações do indivíduo e a busca da qualidade humana se esmaece, de acordo com a gravidade dessa referência.

No caso da adicção ao outro, pensada como traço dos estados fronteiriços, não ocorre necessariamente a transposição de uma relação humana coisificada para um objeto inumano, sem valor de mediação ou ligação, como uma droga pode ser em uma toxicomania. Sobressai a marca fundante da ausência traumática, do vazio e da esperança no outro, ainda em alguma medida presente. Nesses pacientes, é central o paradoxo necessidade da presença do outro versus angústia de invasão (FIGUEIREDO, 2003; BERGERET, 1998; GREEN, 1988b).

Apesar disso, talvez o recurso defensivo de coisificação, do desistir e da recusa da presença humana ainda não tenham se instaurado plenamente. Assim, a adicção ao outro consiste numa busca humana, por mais deteriorada que suas propriedades estejam, esquecidas, apagadas ou distorcidas. A “esperança adictiva”, nesses estados, apresentase como remendo, que faz vislumbrar uma possibilidade de manutenção de um estado 
de integração mínimo, experiência de sentir-se vivo e real pela intensidade e presença postiça, que não pode ser suportada como alteridade. A presença, nesses casos, necessita de um grau de apagamento e controle desse objeto, por conta de um tilt emocional, próprio dos estados-limite, no qual o outro é buscado com sofreguidão e percebido como necessário, mas ao mesmo tempo também como invasivo e ameaçador (FIGUEIREDO, 2003; GREEN, 2000; BERGERET, 1998).

Essa adesão extrema a um objeto, nomeada aqui como "esperança adictiva", é tomada por muitos autores, ao pensarem nas adicções a objetos inanimados, como efeito da pulsão de morte (AUDIBERT, 2008; LE POULICHET, 2005; BRUSSET, 2004; CHAUVET, 2004), por suas características de descarga, repetição, destrutividade e desligamento dos objetos do mundo. McDougall (1992), por sua vez, ao abordar as relações adictivas, aponta a destrutividade como um acontecimento secundário, motivado pela impossibilidade do objeto eleito de atender minimamente a necessidades tão intensas. Trata-se de uma reação, e não de uma tendência primária à destruição ou retorno a estados não vivos.

A autora destaca uma tendência regressiva irrefreável, a busca por uma "mãe primitiva" (MCDOUGALL, 1992, p. 62), ora vivida como excessivamente boa, ora como excessivamente má. Vislumbrada no objeto de adicção, ela deve ser controlada, sob pena de surgirem angústias desestruturantes, caso uma virada brusca transforme aquele porto em abismo. Essa mãe-coisa consiste na impossibilidade de abrigo por um terreno instável, um lugar no outro que não se apresentou possível ou suficiente para a constituição de um Eu integrado. Não se trata apenas de frustração, mas principalmente de desespero e desestruturação, por mais que possa parecer a um observador que ali há alguém próximo a uma criança mimada. Portanto, como um traço marcante dos pacientes fronteiriços, pode-se notar uma ambivalência fundamental e inelutável, condição inclusive utilizada como referência para a formulação dessa compreensão diagnóstica (FONAGY, 2006; KERNBERG, 2006; BERGERET, 1998).

Para McDougall (1992), as adicções e relações adictivas decorrem de fracasso da transicionalidade e da simbolização. Nessa perspectiva, Gurfinkel (2011) as considera patologias do ato ou do agir: elas consistem fundamentalmente em ação, pois não há mediação ou encenação simbólica, não são fenômenos passivos ou mentalizados (FONAGY, 2006). A construção e o desenvolvimento do psíquico permanecem amea- 
çados pelo ato impulsivo e pela incapacidade de representar e de pensar. Essa primazia da ação surge como manifestação emblemática da adicção, na qual o uso compulsivo do objeto obtura o espaço necessário para a transformação psíquica das intensidades pulsionais em elemento pensável, representável e capaz de ser integrado e articulado pelo trabalho da figurabilidade.

O sujeito nessa condição vive uma falência simbólica, aprisionado em um circuito que o aprisiona em uma conduta repetitiva. A tendência à impulsividade, própria da adiç̧ão, ocorre como descarga que não constitui propriamente um acting out tingido por elementos simbólicos, presentes no psiquismo e colocados em ato, em detrimento do pensar e do rememorar, mais característico da neurose, como na histeria. Dessa forma, não há ação vinculada a uma cena determinada pelas vicissitudes pulsionais e pelo conflito entre impulso e defesa como na neurose, sempre remetido a um outro. Diferentemente, no caso das adicções, tal impulsividade se dá como alívio de tensões por meio de descarga imediata fora do campo dos sentidos e da cena que comporta um outro humanizado.

Por isso, não há experiência de articulação direta com a história do sujeito, com suas cenas infantis ou com seus sonhos. Predomina um habitat desértico e empobrecido, no qual a poesia, o brincar e as diversas dimensões de uma experiência permanecem ausentes - trata-se, enfim, de um colapso da transicionalidade (MCDOUGALL, 1992; GURFINKEL, 2001, 2011).

Para a referência freudiana, o agir próprio da adicção (GURFINKEL, 2008) pode ser compreendido como expressão máxima da compulsão à repetição (FREUD, 1920), em decorrência da pulsão de morte. É resultado da energia livre desligada das representações e fruto da sua desvinculação da pulsão de vida. Em uma perspectiva relacional (GREENBERG; MITCHEL, 1994), Winnicott (1963) compreende a compulsão à repetição como resultado de falhas da sustentação do ambiente em momentos cruciais do desenvolvimento.

No caso das relações adictivas nos estados fronteiriços - diferentemente das linhas que fundam a psicopatologia da adicção, em compreensão predominantemente baseada na pulsão de morte -, é possível pensar que há principalmente a busca por uma ligação não acontecida, impedida ou precocemente interrompida. Trata-se, nesse caso, da busca e da falência da hospitalidade do outro, refletida por todas as direções e os 
objetos, uma vivência de não ser abrigado e não estar em coexistência, fenômeno relacional, portanto. Assim, uma adicção também pode ser pensada como escravidão não só ao objeto, mas a uma condição de não acontecimento, clausura em um terreno desértico e sem horizonte construído (BOLLAS, 1994, 1992; WINNICOTT, 1971).

Essa ligação não acontecida pode remeter o sujeito a uma defesa contra o impensável, denominada por Winnicott (1963) de medo do colapso. Refere-se a uma falha na organização do Eu ou desmoronamento dessa organização, que revela um medo de algo que já ocorreu, mas que não pôde ser vivido e integrado como experiência, porque não havia alguém constituído a partir de seu próprio ponto de vista. Para que seja possível viver uma experiência é necessário que haja uma pessoa inteira, um "Self unitário". Assim, a presença ou a ausência traumática não ganha lugar e retorna como angústia impensável. Nesse caminho, a referência de presença e ausência é prejudicada pela interrupção da experiência de simbolização, decorrente dos fenômenos transicionais (WINNICOTT, 1971).

Além disso, está em jogo uma importante dimensão pré-transicional, uma prédisponibilidade para o encontro com o outro e para sua retenção. Tanto a droga como o outro, mesmo coisificado e esvaziado em sua alteridade, podem ser compreendidos como fruto também de uma esperança, como possibilidade de encontrar o que o indivíduo está ansiando, e que espera alcançar com seu movimento desesperado. Nesses momentos iniciais, precedentes ao percurso da transicionalidade, há acontecimentos fundamentais para que o bebê possa integrar-se e assim não dependa compulsivamente de objetos para "encontrar-se a si mesmo", nos moldes da adicção (HUMBERG, 2014).

Nesse sentido, o brincar consiste em uma posição existencial inaugural, que abre caminho para a transicionalidade e cuja distorção e impedimento acarretam consequências desastrosas. Winnicott (1975) compreende o brincar como uma atividade em que o bebê encontra e cria o mundo simultaneamente, além de viver a experiência do encontro consigo mesmo. Nas palavras do psicanalista inglês (1971, p.80): “É no brincar, e somente no brincar, que o indivíduo, criança ou adulto, pode ser criativo e utilizar sua personalidade integral; e é somente sendo criativo que o indivíduo descobre o Eu $($ Self)".

Contudo, a concepção winnicottiana do brincar não corresponde à obtenção de prazer, mas consiste em expressão do verdadeiro Self e sua apropriação. Nesse caminho, 
Winnicott (1971) diferencia o brincar, como condição de integração e constituição do Self, da atividade masturbatória, derivada de intensidades e descargas. Do mesmo modo, Fairbairn (1946/2013) faz a importantíssima observação de que a libido visa o objeto e não o prazer. A partir desse olhar, é possível reconhecer o movimento de busca de si e do outro, nesse exercício primitivo do brincar como fundamento do caminho que leva o indivíduo ao encontro e à comunicação com a alteridade (WINNICOTT, 1967/1971). É possível, portanto, tomar o fronteiriço e a adicção como formas patológicas de busca por um Self, tentativa esperançosa de criar e encontrar uma presença vivida paradoxalmente unida e separada do mundo, condição desesperadamente procurada nesses casos.

Pode existir, portanto, nas adicções, uma preconcepção que não é da ordem estrita do simbólico, mas anterior, e que lança o indivíduo na direção da busca, uma espécie de tropismo, elemento que anseia encontrar e não encontra, como uma intuição do outro (BOLLAS, 1994). Ela carrega a esperança de um continuar a buscar, mesmo impossibilitado de encontrar. No caso da adesão radical a objetos inanimados como a droga, ocorre uma ação defensiva desesperada, já que o outro jamais chega, é quase um “desistir de", um mundo em desencanto.

Parece haver a mesma função na busca pelo outro e pela droga, porém a droga é uma presença pela intensidade, não tem rosto, não é humana. Na adicção do fronteiriço ao outro, o "fio da meada" não foi totalmente perdido, pois não se deu a ultrapassagem radical da referência humana para a coisa inumana. Cabe, portanto, uma discriminação relevante: nas adicções, o uso do objeto varia conforme um gradiente que vai do mais humanizado (pessoas de fato) para o mais coisificado (como a pedra de crack) (CRUZ, 2012).

Sobre as condições desse objeto de adicção, é possível delinear inicialmente um caminho de compreensão, com base num registro fundamentalmente relacional, de esperança por constituição e transformação. É uma referência que não exclui a agressão e a destrutividade, mas que permite pensar em tendências regressivas importantes, na busca por um objeto que carrega uma misteriosa e altamente aguardada promessa. No estudo da adicção ao outro nos pacientes fronteiriços, à parte toda a instabilidade e exuberância do ato e da violência, chama a atenção tal esperança por algo que nunca se dá, uma procura constante no externo e que parece não completar uma experiência que dure e satisfaça (BOLLAS, 1994). 
Para Winnicott (1960), tanto os fronteiriços como os adictos manifestam uma tendência maior à regressão à dependência absoluta, que pode ser compreendida como marca da esperança de encontrar um novo ambiente que propicie a retomada do amadurecimento. Contudo, nesses casos, a dependência de um outro vital ou de um objeto inanimado, que ocupe essa função distorcida, torna-se tão buscada quanto temida.

Para Gurfinkel (2001), as pessoas vítimas da adicção, aqui abarcando também o fronteiriço, estão envolvidas em um duplo movimento. De um lado, combatem as dependências universais inerentes ao ser humano; de outro, vislumbram redescobrir e reencontrar elementos acontecidos ou não na infância, mas de qualquer maneira perdidos. Para o autor, a possibilidade de não viver o temor da dependência se constrói quando o indivíduo pôde experimentar um percurso inicial de não invasão, de sustentação, bem como a resposta de um ambiente que atenda suas necessidades. Trata-se de um paradoxo, portanto, pois em seu caminho o fronteiriço-adicto busca afastar-se da dependência ameaçadora, ao mesmo tempo em que busca um objeto preenchido de esperança numa relação de dependência que se perpetua.

Bollas (1994) apresenta a existência de uma espécie de anseio, nos pacientes fronteiriços, de reencontro com as marcas fundantes da relação eu-outro, tentativa de recuperação de um objeto vacilante, através da turbulência e da intensidade. O autor denomina esse anseio de "desejo borderline". São marcas pré-representacionais que não constituem um objeto exatamente, nem sua representação integral, mas uma espécie de rastro caracterizado por um movimento derivado de uma necessidade extrema.

No lugar de um rosto, o vestígio deixado pelos objetos primários consiste em um turbilhão sensorial, em regressões potencialmente malignas (BALINT, 1968/1993). O que indica a lembrança e a presença do objeto é a turbulência emocional e não a constituição de um objeto interno, representado, minimamente estável e com traços disponíveis para o sujeito. Nesse sentido, Bollas (1994) destaca a necessidade de formação de um primeiro objeto, necessário para a constituição de qualquer ser humano e para o processo de desenvolvimento do Self. Quando essa oferta e constituição falham, resta a tentativa de recuperação dessas marcas primeiras, de estabelecimento de um objeto que não se tornou disponível, nem estável.

Bollas (1994) nomeou de "objeto transformacional” essa primeira apreensão do objeto, que consiste na experiência de alteração do Self, numa espécie de identificação 
que advém do relacionamento de mutualidade mãe-bebê. Nesse processo, o primeiro objeto não se constitui pelo fato de o bebê representá-lo ou ter dele cognição, mas pela experiência recorrente de ser, uma espécie de "conhecer" existencial, em oposição ao representacional.

Para o autor, nesse momento pré-transicional, a mãe ainda não é identificada como objeto, porém é experienciada como um processo de transformação, e essa característica permanece como um resíduo dessa busca objetal na vida adulta. Assim, o sujeito almeja o objeto pela significativa função que este desempenha no processo de transformação do ser. Por isso, na vida adulta, o indivíduo não o busca apenas para possuí-lo, mas com o propósito de render-se a ele como um processo que altera o Self.

Para Bollas (1994), essa identificação se inicia antes que o bebê tenha cognição da presença da mãe, pois essa relação objetal não surge do desejo, mas "de uma espécie de identificação protoperceptual do objeto com sua característica ativa” (p. 64). Consiste no objeto como um transformador ambiental somático do sujeito e se expressa na busca por um outro (pessoa, coisa, lugar, acontecimento, ideologia) que prometa transformar o Self. Essa busca, para o bebê, pode ser completada ou não, e por conta disso há variantes patológicas.

Embora pareça alicerçada em um tempo futuro, esse tipo de experiência pode ocorrer na vida adulta por gerar esperança na procura por algo que transforme o presente. Para o autor, trata-se de uma busca objetal que encene de modo recorrente uma "lembrança” pré-representacional do Self, de caráter estético. Dessa maneira, o que se almeja é uma experiência fundante, lembrança vivencial do objeto inicial, mediante uma intensidade afetiva. É interessante frisar que o autor usa, como exemplo do descaminho patológico na constituição desse objeto, a construção de uma adicção na vida adulta (BOLLAS, 1994, p. 66). O adicto sente ter encontrado um objeto transformacional, capaz de ofertar a conservação do ser e dos estados do Self. O objeto de adicção, para Bollas (1992), tem o poder de instigar, com a ilusão de transformação, essa pessoa passiva e amortecida.

No entanto, tal ilusão de transformação na adicção revela a falta de ilusão no sentido winnicottiano, da criação e da onipotência como posição existencial, e denota, pelo contrário, uma condição de subjugação e submissão ao externo como meio de sobrevivência. Trata-se de uma reversão, na qual os produtos da vida imaginativa da pes- 
soa não cursam o caminho da criação, de suas origens inconscientes, do sonhar e do que é próprio. O sujeito busca atingir os pensamentos e produções pessoais apenas por meio do objeto, como se sua subjetividade fosse inflada somente a partir da presença de um elemento exógeno. Trata-se de pessoalidade postiça, emprestada, e que faz desse indivíduo escravo de um mundo radicalmente externo, que passará e que precisará ser reiteradamente buscado (BOLLAS, 1992). Contudo, a busca pelo outro, por suas marcas e seu potencial de transformação, em relações adictivas ou não, denota necessariamente algum grau de esperança.

É sobre essa busca adictiva por um outro, na esperança de transformar estados gravemente desestruturantes, presente nos pacientes fronteiriços, que o exame de material clínico se dará. A partir dessa apresentação inicial sobre o tema, abre-se espaço para novas considerações sobre a adicção ao outro nesses pacientes, tendo em vista a revisão da literatura sobre o tema e as experiências clínicas concretas compreendidas à luz do método psicanalítico. 
Capítulo II

Revisão Bibliográfica 


\subsection{CONSIDERAÇÕES SOBRE A REVISÃO BIBLIOGRÁFICA DOS TEMAS “ADICÇÃO” E "FRONTEIRIÇO”}

Neste capítulo será apresentado o levantamento sobre a produção científica relacionada ao tema dos fronteiriços e adicções, principalmente no campo psicanalítico. Os conhecimentos são continuamente produzidos, e o acesso a eles tem sido cada vez mais facilitado pelas buscas em bases confiáveis. Nos dias de hoje há muita informação disponível, porém o que confere estatuto científico para uma obra é sua publicação e seu devido reconhecimento pela comunidade acadêmica. As bases de dados indexados consistem em fonte de investigação de material avalizado e, portanto, conferem confiabilidade ao produto de pesquisa. Contudo, adquirir conhecimento não significa apenas reter essas informações, mas utilizá-las de forma crítica para compreender melhor uma realidade.

$\mathrm{Na}$ revisão bibliográfica, o pesquisador tem a oportunidade de aprofundar o tema pesquisado ao analisar o estado do conhecimento no panorama nacional e internacional. Ou seja, pode verificar como estudiosos têm se aproximado de uma determinada problemática - ao observar os objetivos, pressupostos teóricos, estratégias metodológicas e resultados de pesquisas - e realizar uma sistematização dessa revisão. No presente trabalho, esse levantamento figura como objetivo secundário, que visa ao enriquecimento do estudo sobre o possível componente adictivo presente na dinâmica do paciente fronteiriço.

Com esse fim, foram consultadas quatro bases de dados: o Scielo, por oferecer bom acesso a estudos nacionais com parecer da Capes; o PubMed, pela abordagem internacional; o Portal de Periódicos da Capes, que dá acesso a periódicos, artigos e teses nacionais e internacionais; e a Biblioteca Digital de Teses e Dissertações da USP. A busca por trabalhos nessas bases de dados foi realizada em dois momentos, no segundo semestre de 2014 e no primeiro semestre de 2016. Esse levantamento deu acesso a um panorama atualizado sobre os trabalhos que envolvem o tema pesquisado, produzidos em contexto nacional e internacional nos últimos anos.

Esse levantamento enfocou a proposta metodológica e o objetivo dos estudos, a análise e o registro dos resultados, bem como a relevância do trabalho para a presente tese, abrangendo um período de dez anos de produção. 


\subsection{REVISÃO DA BASE DE DADOS SCIELO}

O Scientific Eletronic Library Online - Scielo é uma base de gestão e operação de publicações eletrônicas em rede cooperativa, editadas em coleções de periódicos científicos aprovados para indexação. Isso significa que há um reconhecimento da qualidade acadêmica das produções publicadas, assim como sua validação pela comunidade científica. Tem alcance multidisciplinar, abrangendo diversas áreas do conhecimento, com acesso aberto a estudos publicados em países em desenvolvimento e emergentes. Constitui-se em programa promovido e financiado pela Fundação de Amparo à Pesquisa do Estado de São Paulo (FAPESP) e pelo Conselho Nacional de Ciência e Tecnologia (CNPq), em cooperação técnica com o Centro Latino-Americano e do Caribe de Informação em Ciência da Saúde (Bireme), centro especializado da Organização Pan-Americana da Saúde (OPAS) e da Organização Mundial da Saúde (OMS), orientado à cooperação técnica em informação científica em saúde.

Tabela 3. Palavras-chave pesquisadas no Scielo: borderline; borderline and psicanálise and adicção; borderline and adicção; borderline and psicanálise; borderline and psychoanalysis; borderline and addiction; borderline and adição

\begin{tabular}{|lcc|}
\hline Palavra-chave & $\begin{array}{c}\mathbf{N}^{0} \text { de estudos } \\
\text { em 2014 }\end{array}$ & $\begin{array}{c}\mathbf{N}^{0} \text { de estudos } \\
\text { em } 2016\end{array}$ \\
\hline borderline & 233 & 379 \\
\hline borderline and psicanálise and adicção & 0 & 0 \\
\hline borderline and adicção & 0 & 0 \\
\hline borderline and psicanálise & 10 & 10 \\
\hline borderline and psychoanalysis & 10 & 1 \\
\hline borderline and addiction & 0 & 0 \\
\hline borderline and adição & 0 & 6 \\
\hline borderline and dependência & 2 & 10 \\
\hline
\end{tabular}


A seleção de trabalhos da base de dados Scielo se deu a partir do levantamento de palavras-chave. Inicialmente foi pesquisada a palavra "borderline", por constar na literatura nacional e internacional com grafia em língua inglesa, e assim foram encontrados 233 trabalhos, por isso a pesquisa foi refinada.

Com as palavras-chave "borderline and psicanálise and adicção" (e adição), "borderline and adicção", "borderline and addiction" e "borderline and adição", a busca não retornou nenhum resultado. Já com a terminologia "borderline and psicanálise" foram encontrados dez trabalhos, que constam na tabela abaixo. As tabelas apresentadas neste capítulo serão organizadas em ordem cronológica decrescente de publicação.

Tabela 4. Tema e metodologia dos artigos do Scielo sobre "borderline and psicanálise"

\begin{tabular}{|c|c|c|c|c|}
\hline Referência & Título & Método & Registro & Análise \\
\hline $\begin{array}{l}\text { Villa, F. } \\
\text { (2012) }\end{array}$ & $\begin{array}{l}\text { Mal-estar na civiliza- } \\
\text { ção e desastre totalitá- } \\
\text { rio }\end{array}$ & $\begin{array}{l}\text { Demonstração ar- } \\
\text { gumentativa }^{8}\end{array}$ & $\begin{array}{l}\text { Não es- } \\
\text { pecifica- } \\
\text { do }\end{array}$ & $\begin{array}{l}\text { Não espe- } \\
\text { cificada }\end{array}$ \\
\hline $\begin{array}{l}\text { Nascimento, } \\
\text { A. P. et al } \\
\text { (2011) }\end{array}$ & $\begin{array}{l}\text { Sobre o que se trans- } \\
\text { porta: (Contra)Trans- } \\
\text { ferência(s) }\end{array}$ & $\begin{array}{l}\text { Demonstração ar- } \\
\text { gumentativa }\end{array}$ & $\begin{array}{l}\text { Não es- } \\
\text { pecifica- } \\
\text { do }\end{array}$ & $\begin{array}{l}\text { Não espe- } \\
\text { cificada }\end{array}$ \\
\hline $\begin{array}{l}\text { Jordão, A. B.; } \\
\text { Ramires, V. } \\
\text { R. R. (2010) }\end{array}$ & $\begin{array}{l}\text { Vínculos afetivos en- } \\
\text { tre adolescentes bor- } \\
\text { derline e seus pais. }\end{array}$ & $\begin{array}{l}\text { Estudo de caso } \\
\text { múltiplo, com } \\
\text { abordagem qualita- } \\
\text { tivo-exploratória } \\
\text { (Procedimento: } \\
\text { entrevistas, aplica- } \\
\text { ção do Rorschach, } \\
\text { Desenho da Famí- } \\
\text { lia e Inventário de } \\
\text { Vínculos paren- } \\
\text { tais). }\end{array}$ & $\begin{array}{l}\text { Resposta } \\
\text { dos par- } \\
\text { ticipan- } \\
\text { tes }\end{array}$ & $\begin{array}{l}\text { Análise de } \\
\text { séries } \\
\text { temporais. } \\
\text { Técnica de } \\
\text { síntese de } \\
\text { casos cru- } \\
\text { zados }\end{array}$ \\
\hline $\begin{array}{l}\text { Chagnon, } \\
\text { J. Y. (2009) }\end{array}$ & $\begin{array}{l}\text { Estados-limite nos } \\
\text { trabalhos psicanalíti- } \\
\text { cos franceses }\end{array}$ & $\begin{array}{l}\text { Demonstração ar- } \\
\text { gumentativa }\end{array}$ & $\begin{array}{l}\text { Não es- } \\
\text { pecifica- } \\
\text { do }\end{array}$ & $\begin{array}{l}\text { Não espe- } \\
\text { cificado }\end{array}$ \\
\hline
\end{tabular}

\footnotetext{
${ }^{8}$ De acordo com Eufrasino (2008), demonstração argumentativa consiste em uma perspectiva retórica que diverge da factualidade em si. Parte do pressuposto de que o elemento factual não corresponde a uma imagem especular perfeita do mundo. Essa perspectiva não diverge da informação empírica, mas apresenta um modo de trabalho com suas lacunas.
} 


\begin{tabular}{|c|c|c|c|c|}
\hline $\begin{array}{l}\text { Lionço, T. } \\
(2008)\end{array}$ & $\begin{array}{l}\text { Corpo somático e psi- } \\
\text { quismo na psicanálise: } \\
\text { uma relação de tensi- } \\
\text { onalidade }\end{array}$ & $\begin{array}{l}\text { Demonstração ar- } \\
\text { gumentativa }\end{array}$ & $\begin{array}{l}\text { Não es- } \\
\text { pecifica- } \\
\text { do }\end{array}$ & $\begin{array}{l}\text { Não espe- } \\
\text { cificado }\end{array}$ \\
\hline $\begin{array}{l}\text { Silva, J. F. R.; } \\
\text { Yazigi, L.; } \\
\text { Fiore, M. L. } \\
\text { M. (2008) }\end{array}$ & $\begin{array}{l}\text { Psicanálise e universi- } \\
\text { dade: a interface pos- } \\
\text { sível por meio da pes- } \\
\text { quisa psicanalítica } \\
\text { clínica. Alice quebra- } \\
\text { vidros }\end{array}$ & $\begin{array}{l}\text { Pesquisa clínica de } \\
\text { caso individual } \\
\text { com o método psi- } \\
\text { canalítico/ pesquisa } \\
\text { qualitativa }\end{array}$ & $\begin{array}{l}\text { Registro } \\
\text { de ses- } \\
\text { sões }\end{array}$ & $\begin{array}{l}\text { Os regis- } \\
\text { tros foram } \\
\text { lidos e } \\
\text { relidos } \\
\text { como nar- } \\
\text { rativas, } \\
\text { revelando } \\
\text { momentos } \\
\text { significa- } \\
\text { tivos do } \\
\text { trabalho } \\
\text { da dupla } \\
\text { analista- } \\
\text { paciente. }\end{array}$ \\
\hline $\begin{array}{l}\text { Vidal, P. E. } \\
\text { V. (2008) }\end{array}$ & $\begin{array}{l}\text { A máquina do psi- } \\
\text { quismo }\end{array}$ & Estudo teórico & $\begin{array}{l}\text { Não es- } \\
\text { pecifica- } \\
\text { do }\end{array}$ & $\begin{array}{l}\text { Não espe- } \\
\text { cificado }\end{array}$ \\
\hline $\begin{array}{l}\text { Junqueira, } \\
\text { C.; Coelho } \\
\text { Júnior, N. } \\
\text { (2006) }\end{array}$ & $\begin{array}{l}\text { Freud e as neuroses } \\
\text { atuais: as primeiras } \\
\text { observações psicanalí- } \\
\text { ticas dos quadros bor- } \\
\text { derline? }\end{array}$ & Estudo teórico & $\begin{array}{l}\text { Não es- } \\
\text { pecifica- } \\
\text { do }\end{array}$ & $\begin{array}{l}\text { Não espe- } \\
\text { cificado }\end{array}$ \\
\hline $\begin{array}{l}\text { Zaslavsky, J.; } \\
\text { Santos, M. J. } \\
\text { P. (2005) }\end{array}$ & $\begin{array}{l}\text { Contratransferência } \\
\text { em psicoterapia e psi- } \\
\text { quiatria hoje }\end{array}$ & $\begin{array}{l}\text { Demonstração ar- } \\
\text { gumentativa e dis- } \\
\text { cussão a partir de } \\
\text { material clínico }\end{array}$ & $\begin{array}{l}\text { Não es- } \\
\text { pecifica- } \\
\text { do }\end{array}$ & $\begin{array}{l}\text { Discussão } \\
\text { a partir de } \\
\text { material } \\
\text { clínico }\end{array}$ \\
\hline $\begin{array}{l}\text { Quagliatto, } \\
\text { H. S. M.; } \\
\text { Santos, R. G. } \\
\text { (2004) }\end{array}$ & $\begin{array}{l}\text { Psicoterapia psicanalí- } \\
\text { tica e acompanhamen- } \\
\text { to terapêutico: uma } \\
\text { aliança de trabalho }\end{array}$ & Diálogo reflexivo & $\begin{array}{l}\text { Não es- } \\
\text { pecifica- } \\
\text { do }\end{array}$ & $\begin{array}{l}\text { Não espe- } \\
\text { cificado }\end{array}$ \\
\hline
\end{tabular}

É importante destacar que, mesmo havendo ocorrência das palavras-chave pesquisadas nas obras acima, nenhuma corresponde exatamente ao tema estudado nesta pesquisa. Alguns trabalhos relacionam o contexto cultural contemporâneo a condições psicopatológicas, como os pacientes borderline (VILLA, 2012; JUNQUEIRA, 
COELHO JUNIOR, 2006). Esse contexto é apresentado como sendo marcado pela instabilidade e pelo terror, que leva a estados psíquicos como os estados-limite (VILLA, 2012). Além disso, tais autores relacionam a psicopatologia encontrada por Freud nas neuroses atuais aos pacientes borderline e estabelecem um nexo entre estes (JUNQUEIRA; COELHO JUNIOR, 2006).

Diferentemente dos resultados obtidos nesta base de dados, torna-se importante destacar o contraste entre as produções psicanalíticas disponíveis online e a literatura publicada em livros. Há autores que abordam diretamente as relações entre pacientes borderline e as adicções, porém a pesquisa nessa base de dados indica haver menor número de publicações indexadas disponíveis.

Outros trabalhos abordam aspectos histórico-conceituais e epistemológicos (LIONÇO, 2008; CHAGNON, 2009), discutem desde a história e a evolução do conceito de borderline (CHAGNON, 2009), até a questão do método hermenêutico na construção da psicanálise, assim como a dicotomia entre intensidade e sentido, corpo e psiquismo (LIONÇO, 2008; VIDAL, 2008).

Há trabalhos de caráter mais clínico (NASCIMENTO et al., 2011; JORDÃO; RAMIRES, 2010; SILVA; YAZIGI; FIORE, 2008; ZASLAVSKY; SANTOS, 2005; QUAGLIATTO; SANTOS, 2004), que vão refletir sobre o funcionamento mental de pacientes borderline, assim como sobre aspectos transferenciais-contratransferenciais e as vicissitudes clínicas do manejo no tratamento dessas condições.

Outra consideração importante é que a maioria dos trabalhos levantados faz uma revisão conceitual ou construção teórica (VILLA, 2012; CHAGNON, 2009; LIONÇO, 2008; VIDAL, 2008; JUNQUEIRA; COELHO JUNIOR, 2006). Outra parte dos estudos faz uso de material clínico ou do método psicanalítico como eixo da construção da pesquisa (JORDÃO; RAMIRES, 2010; SILVA; YAZIGI; FIORE, 2008; ZASLAVSKY; SANTOS, 2005; QUAGLIATTO; SANTOS, 2004). De qualquer maneira, apesar de serem fontes fecundas, nenhum dos artigos obtidos se aproximou diretamente do objeto ora pesquisado, a relação de dependência como fenômeno relevante na psicopatologia dos pacientes borderline. O trabalho de Chagnon (2009) auxilia na sistematização e na localização da contribuição de autores franceses, como Bergeret, Green, Diatkine, Mises, Jeammet, Brusset e Chabert, para a construção do campo de 
estudo sobre os pacientes borderline, principalmente acerca da angústia de perda de objeto.

Os trabalhos de Jordão e Ramires (2010), Silva, Yazigi e Fiore (2008), Zaslavsky e Santos (2005) e Quagliatto e Santos (2004) utilizam material clínico, sejam casos, sejam vinhetas ou testes psicológicos, e contribuem para ampliação das reflexões sobre o manejo clínico e a psicopatologia desses pacientes. Contudo, não há abordagem direta sobre a relação do paciente borderline e o vínculo de dependência ou adicção.

A maior parte dos estudos não explicitou o percurso metodológico, tampouco a forma de registro e de análise do material. Por outro lado, os trabalhos trazem contribuições bibliográficas relevantes e convergem com as referências teóricas utilizadas para a fundamentação dessa pesquisa.

Tabela 5. Tema e metodologia dos artigos do Scielo sobre "borderline and psychoanalysis"

\begin{tabular}{|c|c|c|c|c|}
\hline Referência & Título & Método & Registro & Análise \\
\hline $\begin{array}{l}\text { Lauru, D. } \\
\text { (2014) }\end{array}$ & $\begin{array}{l}\text { Etat limite, adolescence, } \\
\text { cannabis et cocaïne }\end{array}$ & $\begin{array}{l}\text { Demonstra- } \\
\text { ção argu- } \\
\text { mentativa }\end{array}$ & $\begin{array}{l}\text { Não espe- } \\
\text { cificado }\end{array}$ & $\begin{array}{l}\text { Não espe- } \\
\text { cificada }\end{array}$ \\
\hline $\begin{array}{l}\text { Sutil, C. R. et } \\
\text { al. (2013) }\end{array}$ & $\begin{array}{l}\text { Reconsiderando la clasifica- } \\
\text { ción psicopatológica desde } \\
\text { el punto de vista psicoanalí- } \\
\text { tico-relacional: lo histérico/ } \\
\text { histriónico como modelo }\end{array}$ & $\begin{array}{l}\text { Demonstra- } \\
\text { ção argu- } \\
\text { mentativa }\end{array}$ & $\begin{array}{l}\text { Não espe- } \\
\text { cificado }\end{array}$ & $\begin{array}{l}\text { Não espe- } \\
\text { cificada }\end{array}$ \\
\hline $\begin{array}{l}\text { Portela de } \\
\text { Carvalho, M. } \\
\text { T.; De Ca- } \\
\text { margo Viana, } \\
\text { T. (2013) }\end{array}$ & $\begin{array}{l}\text { Trauma and the negative } \\
\text { narcissism in borderline } \\
\text { cases }\end{array}$ & $\begin{array}{l}\text { Demonstra- } \\
\text { ção argu- } \\
\text { mentativa }\end{array}$ & $\begin{array}{l}\text { Não espe- } \\
\text { cificado }\end{array}$ & $\begin{array}{l}\text { Não espe- } \\
\text { cificada }\end{array}$ \\
\hline $\begin{array}{l}\text { Muñoz, P. D. } \\
\text { (2009) }\end{array}$ & $\begin{array}{l}\text { Algunas elaboraciones psi- } \\
\text { coanalíticas en torno del uso } \\
\text { del concepto de locura como } \\
\text { distinto del concepto de } \\
\text { psicosis }\end{array}$ & $\begin{array}{l}\text { Demonstra- } \\
\text { ção argu- } \\
\text { mentativa }\end{array}$ & $\begin{array}{l}\text { Não espe- } \\
\text { cificado }\end{array}$ & $\begin{array}{l}\text { Não espe- } \\
\text { cificado }\end{array}$ \\
\hline $\begin{array}{l}\text { Eizirik, M.; } \\
\text { Fonagy, P. } \\
(2009)\end{array}$ & $\begin{array}{l}\text { Mentalization-based treat- } \\
\text { ment for patients with bor- } \\
\text { derline personality disorder: } \\
\text { an overview. }\end{array}$ & $\begin{array}{l}\text { Ensaio clí- } \\
\text { nico contro- } \\
\text { lado ran- } \\
\text { domizado } \\
\text { IOP }\end{array}$ & $\begin{array}{l}\text { Não espe- } \\
\text { cificado }\end{array}$ & $\begin{array}{l}\text { Análise } \\
\text { estatística }\end{array}$ \\
\hline
\end{tabular}


Os artigos encontrados no Scielo a partir da pesquisa com as palavras-chave "borderline and psychoanalysis" abordam em sua maioria questões diagnósticas relevantes sobre o paciente borderline ou discriminações psicopatológicas entre as diferentes estruturas psicanalíticas. O trabalho de Lauru (2014) se relaciona mais diretamente com esta pesquisa por abordar a ligação entre os estados-limite e a busca por cannabis e cocaína. Desde um uso ansiolítico até a exploração dos limites do psiquismo, o artigo expõe aspectos como o medo da loucura, despersonalização e regressões.

Portela de Carvalho e De Camargo Viana (2013) apresentam relevante construção sobre o estatuto do trauma nos pacientes fronteiriços, tema importante para esta pesquisa. As autoras destacam os processos compulsivos nos pacientes fronteiriços, que muitas vezes ocorrem como vício, e revelam como o sujeito procura maneiras de se proteger contra o vazio da impermanência dos objetos. Frisam que, para o fronteiriço, o que é efêmero se destaca e traz consigo a promessa de satisfazer demandas sempre inalcançáveis. Salientam o narcisismo negativo como uma reação defensiva para as condições atuais da subjetividade nesses casos, ou seja, uma reação defensiva contra o excesso de estimulação e as demandas urgentes. Cada indivíduo tem de lidar com uma complexidade para a qual não possui um aparelho de simbolização suficiente. Essa impossibilidade, para as autoras, tem um impacto direto sobre a capacidade de ação e representação.

Os trabalhos de Rodríguez Sutil (2013) e Muñoz (2009) trazem discussões diagnósticas focalizadas na loucura psicótica e na histeria. Tocam indiretamente o tema do fronteiriço, e Rodríguez Sutil (2013), principalmente, contribui com uma localização das fronteiras entre a histeria e o paciente fronteiriço.

O artigo de Eizirik e Fonagy (2009) propõe a verificação da eficácia de um método psicoterapêutico específico para pacientes com diagnóstico de transtorno borderline de personalidade. Esse modelo de pesquisa reflete uma tendência americana e europeia de priorizar estudos que validem a eficácia terapêutica de modelos de psicoterapia, utilizando referências metodológicas quantitativas, em contraposição a estudos que se ocupem da psicopatologia ou da dimensão psicodinâmica desses pacientes. Nesses contextos, contribuições sobre a psicopatologia e psicodinâmica ocupam um lugar secundário, em detrimento de pesquisas de eficácia clínica, principalmente em centros médicos de pesquisa. 
Tabela 6. Tema e metodologia dos artigos do Scielo sobre "borderline and addiction"

\begin{tabular}{lllll}
\hline Referência & Título & Método & Registro & Análise \\
\hline Fernández- & Comorbilidad de la adic- & Revisão siste- & $\begin{array}{l}\text { Não espe- } \\
\text { cificado }\end{array}$ & $\begin{array}{l}\text { Não espe- } \\
\text { cificado }\end{array}$ \\
Montalvo, & ción a la cocaína con los & mática & & \\
J.; Lorea, I. & trastornos de la personali- & & & \\
$(\mathbf{2 0 0 8 )}$ & dad & & & \\
\hline
\end{tabular}

O artigo de Fernández-Montalvo e Lorea (2008) traz uma revisão sobre publicações que abordam a ocorrência da comorbidade entre transtornos de personalidade e dependência de cocaína. Com base em referências psiquiátricas, esse trabalho epidemiológico mostra a importante relação entre tais condições psicopatológicas. De acordo com os autores, os transtornos de personalidade borderline e antissocial são os que apresentam maior prevalência de dependência de cocaína.

Tabela 7. Tema e metodologia dos artigos do Scielo sobre "borderline and dependência"

\begin{tabular}{|c|c|c|c|c|}
\hline Referência & Título & Método & Registro & Análise \\
\hline $\begin{array}{l}\text { Henriques- } \\
\text { Calado, J. et } \\
\text { al. (2013) }\end{array}$ & $\begin{array}{l}\text { Perturbações da personali- } \\
\text { dade como expressão di- } \\
\text { mensional da personalidade } \\
\text { em mulheres idosas }\end{array}$ & Quantitativo & $\begin{array}{l}\text { Questioná- } \\
\text { rio }\end{array}$ & $\begin{array}{l}\text { Estatís- } \\
\text { tica }\end{array}$ \\
\hline $\begin{array}{l}\text { Rioseco, P. S. } \\
\text { et al. (2009) }\end{array}$ & $\begin{array}{l}\text { Prevalencia de trastornos } \\
\text { psiquiátricos en adolescen- } \\
\text { tes infractores de ley: Estu- } \\
\text { dio caso-control }\end{array}$ & $\begin{array}{l}\text { Estudo ob- } \\
\text { servacional e } \\
\text { transversal, } \\
\text { de caso- } \\
\text { controle }\end{array}$ & $\begin{array}{l}\text { Bateria de } \\
\text { instrumen- } \\
\text { tos: DISC } \\
\text { IV, WISC- } \\
\text { R ou WAIS, } \\
\text { e a tela de } \\
\text { História da } \\
\text { Família }\end{array}$ & $\begin{array}{l}\text { Estatís- } \\
\text { tica }\end{array}$ \\
\hline $\begin{array}{l}\text { Santos, S. R. } \\
\text { et al. (2008) }\end{array}$ & $\begin{array}{l}\text { Perfil dos fumantes que pro- } \\
\text { curam um centro de cessa- } \\
\text { ção de tabagismo }\end{array}$ & Quantitativo & $\begin{array}{l}\text { Resposta } \\
\text { dos partici- } \\
\text { pantes }\end{array}$ & $\begin{array}{l}\text { Estatís- } \\
\text { tica }\end{array}$ \\
\hline $\begin{array}{l}\text { Londoño, N. } \\
\text { H. A. et al. } \\
\text { (2007) }\end{array}$ & $\begin{array}{l}\text { Validación del Cuestionario } \\
\text { de Creencias Centrales de } \\
\text { los Trastornos de la Perso- } \\
\text { nalidad (CCE-TP) en pobla- } \\
\text { ción colombiana }\end{array}$ & Quantitativo & $\begin{array}{l}\text { Questioná- } \\
\text { rio }\end{array}$ & $\begin{array}{l}\text { Estatís- } \\
\text { tica }\end{array}$ \\
\hline
\end{tabular}




\begin{tabular}{lllll}
\hline $\begin{array}{l}\text { Lemos Hoyos, } \\
\text { M. } \text { et al. }\end{array}$ & $\begin{array}{l}\text { Construcción y validación } \\
\text { del Cuestionario de Depen- } \\
\text { dencia Emocional en pobla- } \\
\text { ción colombiana }\end{array}$ & Quantitativo & $\begin{array}{l}\text { Questioná- } \\
\text { rio }\end{array}$ & $\begin{array}{l}\text { Estatís- } \\
\text { tica }\end{array}$ \\
$\begin{array}{l}\text { Caixeta, } \text { M. } \\
(1992)\end{array}$ & $\begin{array}{l}\text { Tipos clínicos psicopatoló- } \\
\text { gicos associados ao taba- } \\
\text { gismo }\end{array}$ & $\begin{array}{l}\text { Não especifi- } \\
\text { cado }\end{array}$ & $\begin{array}{l}\text { Não especi- } \\
\text { ficado }\end{array}$ & $\begin{array}{l}\text { Não } \\
\text { especi- } \\
\text { ficado }\end{array}$ \\
\hline
\end{tabular}

O levantamento, na base Scielo, de artigos que fazem uso dos termos "borderline and dependência" gerou seis resultados. Dentre os mais relevantes para o tema ora pesquisado, constam o trabalho de Henriques-Calado et al. (2013) e Rioseco et al (2009), por abordarem a problemática dos transtornos de personalidade, mesmo que indiretamente relacionados a esta pesquisa. Os demais trabalhos versam sobre a validação e construção de escalas e questionários de avaliação e pouco contribuem para a discussão proposta (LONDOÑO et al., 2007; LEMOS HOYOS et al., 2006).

Os demais textos (SANTOS et al., 2008; CAIXETA, 1992) são trabalhos pouco relevantes para a presente pesquisa, pela diferença de objetos, pela abordagem (discussão baseada em categorias psicopatológicas classificatórias) e pelas discussões pouco conclusivas. São trabalhos que se propuseram a pesquisar a etiologia do tabagismo, a classificação psicopatológica e psiquiátrica do usuário. $\mathrm{O}$ primeiro utilizou diversos questionários e fez análise estatística das respostas dos participantes da pesquisa, usuários de um centro de reabilitação de dependência ao tabaco. Trata-se de um ponto de vista clínico e de pesquisa que aborda o tabagismo como desadaptação e propõe a abstinência como oferta terapêutica, sem uma compreensão psicodinâmica, fenomenológica ou comportamental de qualquer processo envolvido nas determinações psicológicas dessa relação. 
Tabela 8. Palavras-chave pesquisadas no Scielo: "fronteiriço"; "fronteiriço and psicanálise and adicção"; "fronteiriço and adicção"; "fronteiriço and psicanálise"; "fronteiriço and adição"; "fronteiriço and dependência"

\begin{tabular}{|lcc|}
\hline Palavra-chave & $\begin{array}{c}\text { Número de } \\
\text { Estudos 2014 }\end{array}$ & $\begin{array}{c}\text { Número de } \\
\text { Estudos 2016 }\end{array}$ \\
\hline fronteiriço & 13 & 24 \\
\hline fronteiriço and psicanálise and adicção & 0 & 0 \\
\hline fronteiriço and adicção & 0 & 1 \\
\hline fronteiriço and psicanálise & 1 & 0 \\
\hline fronteiriço and adição & 0 & 0 \\
\hline fronteiriço and dependência & 0 & 0 \\
\hline
\end{tabular}

A pesquisa empreendida na base Scielo com os descritores "fronteiriço and psicanálise and adicção", "fronteiriço and adicção", "fronteiriço and adição" e "fronteiriço and dependência" não produziu resultado algum.

Com a palavra-chave "fronteiriço", treze artigos foram encontrados em 2014 e vinte e quatro em 2016. Em ambas as datas, somente dois resultados provinham do campo da psicologia, psicanálise ou saúde mental (LIONÇO, 2008; SANTOS; BESSET, 2013). Os demais se originavam de outros campos do conhecimento, como geografia, letras e educação, por isso foram descartados nesse levantamento. O resultado obtido a partir dos termos "fronteiriço and psicanálise", por sua vez, já foi apresentado e discutido na Tabela 4 (LIONÇO, 2008), que trata das palavras-chave "borderline and psicanálise".

Tabela 9. Tema e metodologia dos artigos do Scielo sobre fronteiriço

\begin{tabular}{lllll}
\hline Referência & Título & Método & Registro & Análise \\
\hline $\begin{array}{l}\text { Santos, A. B. } \\
\text { dos R.; Besset, }\end{array}$ & A perversão, o desejo e & Demonstração & $\begin{array}{l}\text { Não espe- } \\
\text { cificado }\end{array}$ & $\begin{array}{l}\text { Não espe- } \\
\text { cificada }\end{array}$ \\
V. L.(2013) & possíveis. & argumentativa & & \\
\hline
\end{tabular}


Como mencionado anteriormente, o estudo de Lionço (2008) foi obtido na busca com a palavra "fronteiriço" e abordado na discussão da Tabela 4, porque também foi encontrado com os termos "borderline and psicanálise". O trabalho de Santos e Besset (2013) trata de outro objeto, a condição fronteiriça do conceito de perversão. Não será, portanto, discutido neste estudo.

Tabela 10. Palavras-chave pesquisadas no Scielo: estados limite; estados-limite and psicanálise; estados-limite and psicanálise and adicção; estados-limite; casos-limite; casos limite; caso limite

\begin{tabular}{|lcc|}
\hline Palavra-chave & $\begin{array}{c}\text { Número de } \\
\text { Estudos 2014 }\end{array}$ & $\begin{array}{c}\text { Número de } \\
\text { Estudos 2016 }\end{array}$ \\
\hline estados limite & 1 & 90 \\
\hline estados-limite and psicanálise & 0 & 0 \\
\hline estados-limite and psicanálise and adicção & 0 & 0 \\
\hline estados-limite & 0 & 90 \\
\hline casos-limite & 0 & 229 \\
\hline casos limite & 0 & 229 \\
\hline caso limite & 0 & 229 \\
\hline
\end{tabular}

Com o levantamento dos termos "estados-limite", "estados-limite and psicanálise", "estados-limite and psicanálise and adicção", "casos-limite", "casos limite" e "caso limite" não foram encontrados resultados em 2014. Apenas ao ser utilizado o descritor "estados limite" isoladamente foi obtido um único estudo, apresentado na Tabela 11 (ALMEIDA-PRADO; FÉRES-CARNEIRO, 2010).

No levantamento de 2016, com os termos de busca "estados limite" e "estadoslimite" foram encontrados noventa resultados. Especificamente, com a palavra "estados limite" foram selecionados 4 estudos significativos: o de Almeida-Prado e FéresCarneiro (2010) já obtido pela busca realizada em 2014, duas ocorrências inéditas (RODRÍGUEZ MOYA; FERNÁNDEZ BELINCHÓN, 2013; SÁNCHEZ QUINTERO; VEJA, 2013), além do estudo de Chagnon (2009) já discutido e apresentado na Tabela 4, que apesenta os resultados da busca por "borderline e psicanálise". 
A busca de 2016 a partir do termo "estados-limite" revelou um trabalho relevante para o tema estudado, que será apresentado na Tabela 12 (CRUZ; VIANA, 2012). Com as palavras-chave "casos-limite", "casos limite" e "caso limite" foram encontrados dez trabalhos na pesquisa de 2016, dois já relacionados nas tabelas 5 e 6 , respectivamente (PORTELA DE CARVALHO; DE CAMARGO VIANA, 2013; FERNÁNDEZMONTALVO; LOREA, 2008) e oito inéditos, que serão apresentados na Tabela 13 e discutidos posteriormente.

A discrepância brusca entre o volume de resultados obtidos em 2014 e 2016 pode indicar um aumento na utilização de palavras-chave correspondentes aos termos aqui utilizados em diferentes campos do conhecimento. Desse fato decorre, provavelmente, a divergência em relação a esta pesquisa e o elevado número de trabalhos descartados. Em outra perspectiva, também pode haver aumento da indexação e disponibilização dos trabalhos, além do crescimento de produções relacionadas, direta e indiretamente, ao campo pesquisado.

Tabela 11. Tema e metodologia dos artigos do Scielo sobre: "estados limite"

\begin{tabular}{|c|c|c|c|c|}
\hline Referência & Título & Método & Registro & Análise \\
\hline $\begin{array}{l}\text { Rodríguez Mo- } \\
\text { ya, L.; Fer- } \\
\text { nández Belin- } \\
\text { chón, C. (2013) }\end{array}$ & $\begin{array}{l}\text { Psicoterapia cognitivo } \\
\text { analítica y trastornos de } \\
\text { la personalidad: revisión }\end{array}$ & $\begin{array}{l}\text { Não especi- } \\
\text { ficado }\end{array}$ & $\begin{array}{l}\text { Não espe- } \\
\text { cificado }\end{array}$ & $\begin{array}{l}\text { Não espe- } \\
\text { cificado }\end{array}$ \\
\hline $\begin{array}{l}\text { Sánchez Quinte- } \\
\text { ro, S.; Vega, I. } \\
\text { (2013) }\end{array}$ & $\begin{array}{l}\text { Introducción al tratami- } \\
\text { ento basado en la menta- } \\
\text { lización para el trastorno } \\
\text { límite de la personalidad }\end{array}$ & $\begin{array}{l}\text { Ensaio clí- } \\
\text { nico ran- } \\
\text { domizado }\end{array}$ & $\begin{array}{l}\text { Não espe- } \\
\text { cificado }\end{array}$ & $\begin{array}{l}\text { Não espe- } \\
\text { cificado }\end{array}$ \\
\hline $\begin{array}{l}\text { Almeida-Prado, } \\
\text { M. C. C.; Féres- } \\
\text { Carneiro, T. } \\
(2010)\end{array}$ & $\begin{array}{l}\text { Violência familiar: obe- } \\
\text { sidade mórbida e função } \\
\text { ômega }\end{array}$ & $\begin{array}{l}\text { Psicanalíti- } \\
\text { co }\end{array}$ & $\begin{array}{l}\text { Não espe- } \\
\text { cificado }\end{array}$ & $\begin{array}{l}\text { Estudo de } \\
\text { caso }\end{array}$ \\
\hline
\end{tabular}

Além do artigo de Chagnon (2009), apresentado na Tabela 4 com os termos "borderline and psicanálise", houve três novos resultados relacionados ao campo da psicologia e saúde mental. O trabalho de Almeida-Prado e Féres-Carneiro (2010) traz significativa contribuição para o estudo do fronteiriço como adicto. Abordam a compul- 
são alimentar e a obesidade mórbida sob o viés do narcisismo e aproximam essas condições do paciente fronteiriço, nos moldes de uma adicção.

Sánchez Quintero e Vega (2013) apresentam trabalho sobre um modelo específico de psicoterapia para pacientes borderline. Apesar de abordarem a dimensão terapêutica, contribuem com excelentes referências bibliográficas e estabelecimento de conceitos sobre o processo de mentalização.

O artigo de Rodríguez Moya e Fernández Belinchón (2013) também aborda especificamente um modelo psicoterapêutico para pacientes borderline, porém se baseia em referências predominantemente cognitivistas e mais distantes do olhar construído nesta pesquisa, além de focar o desenvolvimento do dispositivo psicoterápico.

Tabela 12. Tema e metodologia dos artigos do Scielo sobre: "estados-limite"

\begin{tabular}{lllll}
\hline Referência & Título & Método & Registro & Análise \\
\hline Cruz, W. F. & Limites: a questão do & Demonstração & $\begin{array}{l}\text { Não espe- } \\
\text { cificado }\end{array}$ & $\begin{array}{l}\text { Não espe- } \\
\text { cificado } \\
\text { O.; Viana, T. }\end{array}$ \\
C. (2012) & & argumejo clínico hoje & & \\
\hline
\end{tabular}

Esse estudo faz uma revisão sobre o conceito de estados-limite e sobre a necessidade de mudança da técnica psicanalítica clássica para o atendimento desses pacientes. Trabalho teórico, que visa à discussão da prática psicanalítica contemporânea, esse artigo não tem como objeto a questão pesquisada, mas apresenta confluência de referências bibliográficas sobre o tema dos estados-limite e contribui com a ampliação de fontes sobre o tema.

Tabela 13. Tema e metodologia dos artigos do Scielo sobre: "casos-limite", "casos limite" e "caso limite"

\begin{tabular}{lllll}
\hline Referência & Título & Método & Registro & Análise \\
\hline $\begin{array}{l}\text { Hoffmann, } \\
\text { C.; Costa, R. }\end{array}$ & $\begin{array}{l}\text { Alguns casos, nem neu- } \\
\text { róticos, nem abertamente } \\
\text { psicóticos }\end{array}$ & $\begin{array}{l}\text { Demonstração } \\
\text { argumentativa }\end{array}$ & $\begin{array}{l}\text { Não espe- } \\
\text { cificado }\end{array}$ & $\begin{array}{l}\text { Não espe- } \\
\text { cificada }\end{array}$ \\
$\begin{array}{l}\text { A. (2014) } \\
\text { et antos, N. O. (2014) }\end{array}$ & $\begin{array}{l}\text { Crises não epilépticas } \\
\text { psicogennicas e tratamen- } \\
\text { to psicanalítico: resulta- } \\
\text { dos }\end{array}$ & $\begin{array}{l}\text { Demonstração } \\
\text { argumentativa }\end{array}$ & $\begin{array}{l}\text { Não espe- } \\
\text { cificado }\end{array}$ & $\begin{array}{l}\text { Não espe- } \\
\text { cificada }\end{array}$ \\
& & & & \\
\end{tabular}




\begin{tabular}{|c|c|c|c|c|}
\hline $\begin{array}{l}\text { Castro Mora- } \\
\text { les, J. (2014) }\end{array}$ & $\begin{array}{l}\text { Autolesión no suicida en } \\
\text { adolescentes peruanas: } \\
\text { Una aproximación diag- } \\
\text { nóstica y psicopatológica }\end{array}$ & $\begin{array}{l}\text { Demonstração } \\
\text { argumentativa }\end{array}$ & $\begin{array}{l}\text { Não espe- } \\
\text { cificado }\end{array}$ & $\begin{array}{l}\text { Não espe- } \\
\text { cificada }\end{array}$ \\
\hline $\begin{array}{l}\text { Garciandía } \\
\text { Imaz, J. A. } \\
\text { (2011) }\end{array}$ & $\begin{array}{l}\text { Secuestro y psicopato- } \\
\text { logía. Lo monstruoso }\end{array}$ & $\begin{array}{l}\text { Demonstração } \\
\text { argumentativa }\end{array}$ & $\begin{array}{l}\text { Não espe- } \\
\text { cificado }\end{array}$ & $\begin{array}{l}\text { Não espe- } \\
\text { cificada }\end{array}$ \\
\hline $\begin{array}{l}\text { Tamayo, } \\
\text { J. M. et al. } \\
(2011)\end{array}$ & $\begin{array}{l}\text { Definición e impacto de } \\
\text { las depresiones resisten- } \\
\text { tes/refractarias al trata- } \\
\text { miento }\end{array}$ & $\begin{array}{l}\text { Demonstração } \\
\text { argumentativa }\end{array}$ & $\begin{array}{l}\text { Não espe- } \\
\text { cificado }\end{array}$ & $\begin{array}{l}\text { Não espe- } \\
\text { cificada }\end{array}$ \\
\hline $\begin{array}{l}\text { García Ló- } \\
\text { pez, M. T. et } \\
\text { al. (2010) }\end{array}$ & $\begin{array}{l}\text { Tratamiento integral del } \\
\text { Trastorno Límite de Per- } \\
\text { sonalidad psicanalítica }\end{array}$ & $\begin{array}{l}\text { Revisão siste- } \\
\text { mática }\end{array}$ & $\begin{array}{l}\text { Não espe- } \\
\text { cificado }\end{array}$ & $\begin{array}{l}\text { Não espe- } \\
\text { cificada }\end{array}$ \\
\hline $\begin{array}{l}\text { Pimentel, P. } \\
\text { K. A.; Coelho } \\
\text { Junior, N. } \\
\text { (2009) }\end{array}$ & $\begin{array}{l}\text { Algumas considerações } \\
\text { sobre o uso da empatia } \\
\text { em casos e situações li- } \\
\text { mite }\end{array}$ & Estudo teórico & $\begin{array}{l}\text { Não espe- } \\
\text { cificado }\end{array}$ & $\begin{array}{l}\text { Não espe- } \\
\text { cificada }\end{array}$ \\
\hline $\begin{array}{l}\text { Dias, E. O. } \\
(2008)\end{array}$ & $\begin{array}{l}\text { O uso da interpretação na } \\
\text { clínica do amadureci- } \\
\text { mento }\end{array}$ & Estudo teórico & $\begin{array}{l}\text { Não espe- } \\
\text { cificado }\end{array}$ & $\begin{array}{l}\text { Não espe- } \\
\text { cificada }\end{array}$ \\
\hline
\end{tabular}

Além dos trabalhos de Portela de Carvalho e De Camargo Viana (2013) e de Fernández-Montalvo e Lorea (2008), apresentados respectivamente nas Tabelas 5 e 6 , foram encontrados mais oito ocorrências pertinentes ao campo do presente estudo. Entre elas, os artigos de Hoffmann e Costa (2014), García López et al. (2010) e Pimentel e Coelho Junior (2009) se destacam em relação à pertinência para a presente pesquisa, devido à proximidade dos temas. Os demais trabalhos também consistem em material com qualidade relevante e adotam olhares convergentes, porém os objetos de pesquisa são mais distantes.

O artigo de Hoffmann e Costa (2014) aponta para a compreensão do fronteiriço marcado inconscientemente pela experiência de perda do objeto primordial, cujas resultantes são a capacidade de julgamento e o princípio de realidade. Para os autores, o "não limite" dessas subjetividades articula-se com a aceleração contemporânea do tempo entre o julgar e a ação. García López et al. (2010) fazem uma boa revisão do conceito borderline, com referências relevantes, apesar de apresentarem um modelo psicotera- 
pêutico específico. O trabalho de Pimentel e Coelho Junior (2009) se debruça sobre o manejo de casos limite, abordando historicamente os impasses técnicos no tratamento de pacientes difíceis, além de contribuir com boas referências bibliográficas.

Os demais trabalhos de Santos et al. (2014), Castro Morales (2014), Garciandía Imaz (2011), Tamayo et al. (2011) e Dias (2008) não tocam diretamente as questões mais centrais aqui abordadas, por isso não serão priorizadas na construção da presente pesquisa, embora sejam artigos bem construídos e evidentemente consistentes.

Tabela 14. Outras palavras-chave pesquisadas no Scielo

\begin{tabular}{|lcc|}
\hline Palavra-chave & $\begin{array}{c}\mathbf{N}^{0} \text { estudos } \\
2014\end{array}$ & $\begin{array}{c}\mathbf{N}^{0} \text { estudos } \\
2016\end{array}$ \\
\hline $\begin{array}{l}\text { transtorno de personalidade borderline } \\
\text { DSM-IV/ DSM-V }\end{array}$ & 4 & 10 \\
\hline $\begin{array}{l}\text { transtorno de personalidade limítrofe } \\
\text { CID-10 }\end{array}$ & 1 & 1 \\
\hline $\begin{array}{l}\text { transtorno de personalidade emocionalmente instável } \\
\text { CID-10 }\end{array}$ & 0 & 1 \\
\hline $\begin{array}{l}\text { transtorno de personalidade borderline and psicanálise } \\
\text { transtorno de personalidade borderline and psicanálise } \\
\text { and adicção }\end{array}$ & 1 & 0 \\
\hline $\begin{array}{l}\text { transtorno de personalidade borderline and psicanálise } \\
\text { and adição }\end{array}$ & 0 & 0 \\
\hline \begin{tabular}{l} 
transtorno de personalidade borderline and dependência \\
\hline
\end{tabular} & 0 & 0 \\
\hline
\end{tabular}

Tanto em 2014 como em 2016, o levantamento na base Scielo com os descritores "transtorno de personalidade emocionalmente instável", "transtorno de personalidade borderline and psicanálise and adicção", "transtorno de personalidade borderline and psicanálise and adição" e "transtorno de personalidade borderline and dependência" não retornou nenhum resultado.

Na pesquisa de 2014 com as palavras-chave "transtorno de personalidade borderline”, surgiram quatro ocorrências, além do artigo de Silva, Yazigi e Fiore (2008), já 
apresentado na discussão da Tabela 4. A pesquisa de 2016 revelou mais cinco ocorrências inéditas, totalizando dez ocorrências nas duas buscas. Esses trabalhos serão apresentados e discutidos na Tabela 15.

Com os termos "transtorno de personalidade limítrofe", tanto em 2014 como em 2016, foi encontrado o trabalho de Carvalho, Stracke e Souza (2004), que será discutido na Tabela 16. Na busca de 2016 com os termos "transtorno de personalidade borderline and psicanálise" houve novamente ocorrência do artigo de Silva, Yazigi e Fiore (2008), já apresentado na discussão da Tabela 4.

Tabela 15. Tema e metodologia dos artigos do Scielo sobre "transtorno de personalidade borderline"

\begin{tabular}{|c|c|c|c|c|}
\hline Referência & Título & Método & Registro & Análise \\
\hline $\begin{array}{l}\text { Moraes et al. } \\
\text { (2013) }\end{array}$ & $\begin{array}{l}\text { Relação entre aspectos } \\
\text { clínicos e neuropsicoló- } \\
\text { gicos e as tentativas de } \\
\text { suicídio em pacientes } \\
\text { eutímicos com transtorno } \\
\text { afetivo bipolar }\end{array}$ & $\begin{array}{l}\text { Demonstração } \\
\text { argumentativa }\end{array}$ & $\begin{array}{l}\text { Não espe- } \\
\text { cificado }\end{array}$ & $\begin{array}{l}\text { Não espe- } \\
\text { cificada }\end{array}$ \\
\hline $\begin{array}{l}\text { Rosa, B. P.; } \\
\text { Santos, M. A. } \\
\text { (2011) }\end{array}$ & $\begin{array}{l}\text { Comorbidade entre buli- } \\
\text { mia e transtorno de per- } \\
\text { sonalidade borderline: } \\
\text { implicações para o trata- } \\
\text { mento }\end{array}$ & Estudo de caso & $\begin{array}{l}\text { Não espe- } \\
\text { cificado }\end{array}$ & $\begin{array}{l}\text { Enfoque } \\
\text { psicanalí- } \\
\text { tico utili- } \\
\text { zado para } \\
\text { análise } \\
\text { dos dados }\end{array}$ \\
\hline $\begin{array}{l}\text { Jordão, A. B.; } \\
\text { Ramires, V. } \\
\text { R. R. (2010) }\end{array}$ & $\begin{array}{l}\text { Adolescência e organiza- } \\
\text { ção de personalidade } \\
\text { borderline: caracteriza- } \\
\text { ção dos vínculos afetivos }\end{array}$ & Revisão & $\begin{array}{l}\text { Não espe- } \\
\text { cificado }\end{array}$ & $\begin{array}{l}\text { Não espe- } \\
\text { cificada }\end{array}$ \\
\hline $\begin{array}{l}\text { Vidal, M.; } \\
\text { Lowenkron, } \\
\text { T. (2010) }\end{array}$ & $\begin{array}{l}\text { Ensino da psicoterapia no } \\
\text { atendimento psiquiátrico } \\
\text { dos pacientes com trans- } \\
\text { torno de personalidade } \\
\text { borderline }\end{array}$ & $\begin{array}{l}\text { Revisão da } \\
\text { literatura }\end{array}$ & $\begin{array}{l}\text { Não espe- } \\
\text { cificado }\end{array}$ & $\begin{array}{l}\text { Análise de } \\
\text { conteúdo }\end{array}$ \\
\hline $\begin{array}{l}\text { Nunes Costa } \\
\text { et al. (2009) }\end{array}$ & $\begin{array}{l}\text { Teoria e eficácia da tera- } \\
\text { pia comportamental dia- } \\
\text { lética na bulimia nervosa } \\
\text { e no transtorno da com- } \\
\text { pulsão alimentar periódi- } \\
\text { ca }\end{array}$ & $\begin{array}{l}\text { Demonstração } \\
\text { argumentativa }\end{array}$ & $\begin{array}{l}\text { Não espe- } \\
\text { cificado }\end{array}$ & $\begin{array}{l}\text { Não espe- } \\
\text { cificada }\end{array}$ \\
\hline
\end{tabular}




\begin{tabular}{|c|c|c|c|c|}
\hline $\begin{array}{l}\text { Tanesi, P. H. } \\
\text { V. et al. } \\
\text { (2007). }\end{array}$ & $\begin{array}{l}\text { Adesão ao tratamento } \\
\text { clínico no transtorno de } \\
\text { personalidade borderline }\end{array}$ & $\begin{array}{l}\text { Estudo qualita- } \\
\text { tivo, entrevista } \\
\text { e classificação } \\
\text { diagnóstica e } \\
\text { acompanha- } \\
\text { mento clínico }\end{array}$ & $\begin{array}{l}\text { Não espe- } \\
\text { cificado }\end{array}$ & $\begin{array}{l}\text { Leituras } \\
\text { sistemáti- } \\
\text { cas do } \\
\text { material/ } \\
\text { análise } \\
\text { indutiva }\end{array}$ \\
\hline $\begin{array}{l}\text { Alcantara, I. } \\
\text { et al. (2003) }\end{array}$ & $\begin{array}{l}\text { Avanços no diagnóstico } \\
\text { do transtorno do humor } \\
\text { bipolar }\end{array}$ & Estudo teórico & $\begin{array}{l}\text { Não espe- } \\
\text { cificado }\end{array}$ & $\begin{array}{l}\text { Não espe- } \\
\text { cificada }\end{array}$ \\
\hline $\begin{array}{l}\text { Dal'Pizol, A. } \\
\text { et al. (2003) }\end{array}$ & $\begin{array}{l}\text { Programa de abordagem } \\
\text { interdisciplinar no trata- } \\
\text { mento do transtorno de } \\
\text { personalidade borderline: } \\
\text { relato da experiência no } \\
\text { ambulatório Melanie } \\
\text { Klein do Hospital Psiqui- } \\
\text { átrico São Pedro }\end{array}$ & $\begin{array}{l}\text { Demonstração } \\
\text { argumentativa }\end{array}$ & $\begin{array}{l}\text { Não espe- } \\
\text { cificado }\end{array}$ & $\begin{array}{l}\text { Não espe- } \\
\text { cificada }\end{array}$ \\
\hline $\begin{array}{l}\text { Cunha, P. J.; } \\
\text { Azevedo, M. } \\
\text { A. S. B. } \\
\text { (2001) }\end{array}$ & $\begin{array}{l}\text { Um caso de transtorno de } \\
\text { personalidade borderline } \\
\text { atendido em psicoterapia } \\
\text { dinâmica breve }\end{array}$ & $\begin{array}{l}\text { Não especifi- } \\
\text { cado }\end{array}$ & $\begin{array}{l}\text { Temas } \\
\text { principais } \\
\text { das ses- } \\
\text { sões }\end{array}$ & $\begin{array}{l}\text { Evolução } \\
\text { do aten- } \\
\text { dimento }\end{array}$ \\
\hline
\end{tabular}

Os artigos levantados se detêm, predominantemente, nas questões relativas ao tratamento do transtorno de personalidade borderline, problemas de adesão e manejo. Não se aproximam do objeto da presente pesquisa, porém contribuem com relevantes referências bibliográficas e discussões (MORAES et al., 2013; NUNES COSTA et al., 2009; ALCANTARA et al, 2003; DAL'PIZOL et al., 2003). Trata-se de estudos clínicos voltados para a verificação da eficácia de proposições terapêuticas específicas, sendo elaborados principalmente a partir de resultados de atendimentos. Uma das pesquisas (VIDAL; LOWENKRON, 2010) apresenta a necessidade de uma formação psicoterapêutica específica para os psiquiatras atenderem esses pacientes.

Embora a metodologia qualitativa seja empregada, o método clínico não é o único recurso metodológico: escalas diagnósticas são utilizadas, e os trabalhos estão alinhados com uma referência psiquiátrica do transtorno de personalidade borderline.

O artigo de Rosa e Santos (2011) apresenta discussão, a partir de material clínico, sobre a aproximação da bulimia e do paciente borderline, acrescentando material para a articulação do fronteiriço e diferentes formas de adicção. Jordão e Ramires 
(2010) trazem revisão sobre o tema da adolescência e do paciente fronteiriço. A partir da contextualização da cultura, elencam autores significativos e contribuem com boas referências.

Tabela 16. Tema e metodologia dos artigos do Scielo sobre "transtorno de personalidade limítrofe"

\begin{tabular}{lllll}
\hline Referência & Título & Método & Registro & Análise \\
\hline Carvalho, & Tratamento farmacoló- & Revisão & Fichas indi- & Categoriza- \\
A.F.; Stracke, & gico do transtorno de & sistemática & viduais por & ção dos \\
C.B.; Souza, & personalidade limítrofe: & & estudo & estudos \\
F.G.M. (2004) & $\begin{array}{l}\text { revisão crítica da litera- } \\
\text { tura e desenvolvimento } \\
\text { de algoritmos }\end{array}$ & & \\
& & & \\
\hline
\end{tabular}

O estudo de Carvalho, Stracke e Souza (2004), obtido pela busca com o termo "transtorno de personalidade limítrofe", aborda a terapêutica psicofarmacológica de pacientes borderline. Consiste em pesquisa médica sobre as drogas mais pertinentes para tratamento desse quadro psiquiátrico. Assim, é uma referência pouco fecunda para esta pesquisa, apesar de sua consistência metodológica.

\subsection{REVISÃO DA BASE DE DADOS PUBMED}

O PubMed é uma ferramenta de busca gratuita que dá acesso, principalmente, ao banco de dados Medline, de referências e resumos sobre ciências da vida e temas da saúde. A Biblioteca Nacional de Medicina Norte-Americana (NLM) e o banco de dados norte-americano Bireme mantêm essa base, como parte do sistema Entrez de recuperação da informação.

Oferece mais de 21 milhões de referências a pesquisas da área de saúde e ciências da vida e inclui citações de mais de 5.600 periódicos acadêmicos publicados em todo o mundo. Possui um comitê consultivo e de seleção técnica, que analisa e recomenda o material submetido. A partir de diretrizes próprias, esse comitê considera a qualidade, a originalidade e a importância do conteúdo científico de uma revista para o público global Medline. 
Tabela 17. Palavras-chave pesquisadas no PubMed: borderline, addiction, borderline and addiction, borderline disorder and addiction, borderline and psychoanalysis, addiction and psychoanalysis, borderline disorder and psychoanalysis, borderline and addiction and psychoanalysis

\begin{tabular}{|lcc|}
\hline Palavra-chave & $\mathbf{N}^{0}$ estudos & $\mathbf{N}^{0}$ estudos \\
\hline borderline & 2014 & 2016 \\
\hline addiction & 32.439 & 34.786 \\
\hline borderline and addiction & 45.369 & 51.543 \\
\hline borderline disorder and addiction & 187 & 234 \\
\hline borderline and psychoanalysis & 142 & 181 \\
\hline addiction and psychoanalysis & 163 & 173 \\
\hline borderline disorder and psychoanalysis & 37 & 41 \\
\hline borderline and addiction and psychoalalysis & 125 & 132 \\
\hline
\end{tabular}

Por se tratar de base de dados internacional americana, optou-se pela utilização de terminologia exclusiva dessa língua, além de trabalhos de outras nacionalidades incluírem descritores em inglês. Para essa busca, foi selecionado apenas o termo "borderline”, em inglês, pois ele não sofreu as distorções advindas da língua francesa, como ocorre em português. O levantamento por publicações da base de dados PubMed ocorreu, inicialmente, através da pesquisa das palavras-chave "borderline”, com 32.439 ocorrências em 2014 e 34.786 em 2016; “addiction”, com 45.369 resultados em 2014 e 51.543 em 2016.

Diante da quantidade elevada de artigos, a busca foi refinada com a utilização das palavras "Borderline and addiction”, com 187 resultados em 2014 e 234 em 2016, “borderline disorder and addiction”, com 142 textos em 2014 e 181 em 2016, "borderline and psychoanalysis", com 163 estudos em 2014 e 173 em 2016, "addiction and psychoanalysis" com 37 respostas em 2014 e 41 em 2016, e "borderline disorder and psychoanalysis”, com 125 textos em 2014 e 132 em 2016. Mesmo esse volume de material ainda foi considerado grande para a presente revisão, por isso procedeu-se à busca com os termos "borderline and addiction and psychoalalysis", o que levou a apenas 
dois resultados em 2014 e 2016. Ambos os trabalhos foram descartados desse levantamento, pois um consta da Tabela 18 (GABBERT, 2009), sendo discutido abaixo, e o outro data de 1993, período anterior ao pesquisado, além de abordar questões colaterais sobre grupos de ajuda mútua, do tipo doze passos.

Por fim, foi escolhido um total de dezenove trabalhos, que serão discutidos na tabela abaixo. Para a seleção, foram considerados não apenas os 37 estudos encontrados em 2014 e os 41 revelados em 2016 com a pesquisa das palavras "addiction and psychoanalysis", mas também os resumos dos 234 artigos sobre "borderline and addiction", dos 181 sobre "borderline disorder and addiction" e dos 183 sobre "borderline and psychoanalysis" publicados nos últimos dez anos.

Tabela 18. Tema e metodologia dos artigos do PubMed sobre "addiction and psychoanalysis", "borderline and addiction", "borderline disorder and addiction", "borderline and psychoanalysis"

\begin{tabular}{|c|c|c|c|c|}
\hline Referência & Título & Método & Registro & Análise \\
\hline $\begin{array}{l}\text { Schubler, } \\
\text { G. (2014) }\end{array}$ & $\begin{array}{l}\text { How addiction develops } \\
\text { and what are the } \\
\text { consequences - a psycho- } \\
\text { dynamic approach. Addic- } \\
\text { tion and psychodynamic } \\
\text { aspects }\end{array}$ & $\begin{array}{l}\text { OPD-2 Di- } \\
\text { agnóstico } \\
\text { psicodinâ- } \\
\text { mico opera- } \\
\text { cionalizado }\end{array}$ & $\begin{array}{l}\text { Não especi- } \\
\text { ficado }\end{array}$ & $\begin{array}{l}\text { Não especi- } \\
\text { ficada }\end{array}$ \\
\hline $\begin{array}{l}\text { Bendat, M. } \\
\text { (2014) }\end{array}$ & $\begin{array}{l}\text { In name only? Mental } \\
\text { health parity or illusory } \\
\text { reform }\end{array}$ & $\begin{array}{l}\text { Demonstra- } \\
\text { ção argu- } \\
\text { mentativa }\end{array}$ & $\begin{array}{l}\text { Não especi- } \\
\text { ficado }\end{array}$ & $\begin{array}{l}\text { Não especi- } \\
\text { ficada }\end{array}$ \\
\hline $\begin{array}{l}\text { Kradin, R. } \\
(2014)\end{array}$ & $\begin{array}{l}\text { Converting a freudian anal- } \\
\text { ysis into a jungian one: } \\
\text { obsesion addiction and an- } \\
\text { swer from job. }\end{array}$ & $\begin{array}{l}\text { Estudo de } \\
\text { caso }\end{array}$ & $\begin{array}{l}\text { Não especi- } \\
\text { ficado }\end{array}$ & $\begin{array}{l}\text { Não especi- } \\
\text { ficada }\end{array}$ \\
\hline $\begin{array}{l}\text { Bazan, A; } \\
\text { Detandt, S. } \\
(2013)\end{array}$ & $\begin{array}{l}\text { On the physiology of jouis- } \\
\text { sance: interpreting the } \\
\text { mesolimbic dopaminergic } \\
\text { reward functions from a } \\
\text { psychoanalytic perspective }\end{array}$ & $\begin{array}{l}\text { Estudo teóri- } \\
\text { co }\end{array}$ & $\begin{array}{l}\text { Não especi- } \\
\text { ficado }\end{array}$ & $\begin{array}{l}\text { Não especi- } \\
\text { ficada }\end{array}$ \\
\hline $\begin{array}{l}\text { Johnson, } \\
\text { B. (2013) }\end{array}$ & Addiction and will & $\begin{array}{l}\text { Não especi- } \\
\text { ficado }\end{array}$ & $\begin{array}{l}\text { Não especi- } \\
\text { ficado }\end{array}$ & $\begin{array}{l}\text { Não especi- } \\
\text { ficada }\end{array}$ \\
\hline $\begin{array}{l}\text { Mann K. } \\
\text { (2013) }\end{array}$ & $\begin{array}{l}\text { Behavioral addiction: New } \\
\text { challenges for psychiatrists } \\
\text { and psychotherapists? }\end{array}$ & $\begin{array}{l}\text { Estudo teóri- } \\
\text { co }\end{array}$ & $\begin{array}{l}\text { Não especi- } \\
\text { ficado }\end{array}$ & $\begin{array}{l}\text { Não especi- } \\
\text { ficada }\end{array}$ \\
\hline
\end{tabular}




\begin{tabular}{|c|c|c|c|c|}
\hline $\begin{array}{l}\text { Matusow, } \\
\text { H.; Rosen- } \\
\text { blum, A. } \\
\text { (2013) }\end{array}$ & $\begin{array}{l}\text { The most critical unre- } \\
\text { solved issue associated with } \\
\text { psychoanalytic theories of } \\
\text { addiction: can the talking } \\
\text { cure tell us anything about } \\
\text { substance use and misuse? }\end{array}$ & $\begin{array}{l}\text { Estudo } \\
\text { teórico }\end{array}$ & $\begin{array}{l}\text { Não especi- } \\
\text { ficado }\end{array}$ & $\begin{array}{l}\text { Não especi- } \\
\text { ficada }\end{array}$ \\
\hline $\begin{array}{l}\text { Berner, W, } \\
\text { Briken, P. } \\
\text { (2012) }\end{array}$ & $\begin{array}{l}\text { Pleasure seeking and the } \\
\text { aspect of longing for an } \\
\text { object in perversion. }\end{array}$ & $\begin{array}{l}\text { Estudo } \\
\text { teórico }\end{array}$ & $\begin{array}{l}\text { Não especi- } \\
\text { ficado }\end{array}$ & $\begin{array}{l}\text { Não especi- } \\
\text { ficada }\end{array}$ \\
\hline $\begin{array}{l}\text { Essig, T. } \\
\text { (2012) }\end{array}$ & $\begin{array}{l}\text { The addiction concept } \\
\text { and technology: diagnosis, } \\
\text { metaphor, or something } \\
\text { else? A psychodynamic } \\
\text { point of view. }\end{array}$ & $\begin{array}{l}\text { Estudo de } \\
\text { caso }\end{array}$ & $\begin{array}{l}\text { Não especi- } \\
\text { ficado }\end{array}$ & $\begin{array}{l}\text { Não especi- } \\
\text { ficada }\end{array}$ \\
\hline $\begin{array}{l}\text { Estellon, } \\
\text { V, Mouras, } \\
\text { H. } \\
\text { (2012) }\end{array}$ & $\begin{array}{l}\text { Sexual addiction: insights } \\
\text { from psychoanalysis and } \\
\text { functional neuroimaging. }\end{array}$ & $\begin{array}{l}\text { Não especi- } \\
\text { ficado }\end{array}$ & $\begin{array}{l}\text { Não especi- } \\
\text { ficado }\end{array}$ & $\begin{array}{l}\text { Não especi- } \\
\text { ficada }\end{array}$ \\
\hline $\begin{array}{l}\text { Johnson, } \\
\text { B. (2011) }\end{array}$ & $\begin{array}{l}\text { Psychoanalytic treatment of } \\
\text { psychological addiction to } \\
\text { alcohol (alcohol abuse). }\end{array}$ & $\begin{array}{l}\text { Estudo } \\
\text { de caso } \\
\text { combinado } \\
\text { com obser- } \\
\text { vações epi- } \\
\text { demiológica, } \\
\text { neurobioló- } \\
\text { gicas, longi- } \\
\text { tudinais e } \\
\text { psicanalíti- } \\
\text { cas }\end{array}$ & $\begin{array}{l}\text { Registro de } \\
\text { sessões }\end{array}$ & $\begin{array}{l}\text { Não especi- } \\
\text { ficada }\end{array}$ \\
\hline $\begin{array}{l}\text { Kemp, R. } \\
\text { (2011) }\end{array}$ & $\begin{array}{l}\text { The symbolic constitution } \\
\text { of addiction: language, } \\
\text { alienation, ambivalence. }\end{array}$ & $\begin{array}{l}\text { Não especi- } \\
\text { ficado }\end{array}$ & $\begin{array}{l}\text { Não especi- } \\
\text { ficado }\end{array}$ & $\begin{array}{l}\text { Não especi- } \\
\text { ficada }\end{array}$ \\
\hline $\begin{array}{l}\text { De Rick, } \\
\text { A.; Van- } \\
\text { heule, S.; } \\
\text { Ver- } \\
\text { haeghe, P. } \\
(2009)\end{array}$ & $\begin{array}{l}\text { Alcohol addiction and the } \\
\text { attachment system: an em- } \\
\text { pirical study of attachment } \\
\text { style, alexithymia, and psy- } \\
\text { chiatric disorders in alco- } \\
\text { holic inpatients. }\end{array}$ & $\begin{array}{l}\text { Quantitativo } \\
\text { com uso de } \\
\text { escalas }\end{array}$ & $\begin{array}{l}\text { Não especi- } \\
\text { ficado }\end{array}$ & $\begin{array}{l}\text { Análise de } \\
\text { agrupamento } \\
\text { e de regres- } \\
\text { são dos da- } \\
\text { dos }\end{array}$ \\
\hline $\begin{array}{l}\text { Gabbert, } \\
\text { T. G. } \\
(2009)\end{array}$ & $\begin{array}{l}\text { The application of the theo- } \\
\text { ry of narcissism in criminal } \\
\text { proceedings }\end{array}$ & $\begin{array}{l}\text { Estudo teóri- } \\
\text { co }\end{array}$ & $\begin{array}{l}\text { Não especi- } \\
\text { ficado }\end{array}$ & $\begin{array}{l}\text { Não especi- } \\
\text { ficada }\end{array}$ \\
\hline
\end{tabular}




\begin{tabular}{|c|c|c|c|c|}
\hline $\begin{array}{l}\text { Valentine, } \\
\text { K.; Fraser, } \\
\text { S. (2008) }\end{array}$ & $\begin{array}{l}\text { Trauma, damage and pleas- } \\
\text { ure: rethinking problematic } \\
\text { drug use. }\end{array}$ & $\begin{array}{l}\text { Entrevista } \\
\text { Qualitativa }\end{array}$ & $\begin{array}{l}\text { Não especi- } \\
\text { ficado }\end{array}$ & $\begin{array}{l}\text { Leitura críti- } \\
\text { ca baseada } \\
\text { na psicanáli- } \\
\text { se }\end{array}$ \\
\hline $\begin{array}{l}\text { De Rick, } \\
\text { A.; Van- } \\
\text { heule, S. } \\
\text { (2007) }\end{array}$ & $\begin{array}{l}\text { Attachment styles in alco- } \\
\text { holic inpatients }\end{array}$ & Quantitativo & $\begin{array}{l}\text { Não especi- } \\
\text { ficado }\end{array}$ & Estatística \\
\hline $\begin{array}{l}\text { Petersen, } \\
\text { T. et al } \\
(2007)\end{array}$ & $\begin{array}{l}\text { Does psychiatry residency } \\
\text { training reflect the "real } \\
\text { world" of psychiatry prac- } \\
\text { tice? A survey of residency } \\
\text { graduates. }\end{array}$ & $\begin{array}{l}\text { Quantitativo } \\
\text { com uso de } \\
\text { entrevistas e } \\
\text { escalas }\end{array}$ & $\begin{array}{l}\text { Entrevistas } \\
\text { a distância }\end{array}$ & Estatística \\
\hline $\begin{array}{l}\text { Press, C. } \\
\text { M. }(2005)\end{array}$ & $\begin{array}{l}\text { Psychoanalysis, creativity, } \\
\text { and hope: forward edge } \\
\text { strivings in the life and } \\
\text { work of choreographer Paul } \\
\text { Taylor. }\end{array}$ & $\begin{array}{l}\text { Estudo bio- } \\
\text { gráfico }\end{array}$ & $\begin{array}{l}\text { Não especi- } \\
\text { ficado }\end{array}$ & Psicanalítica \\
\hline $\begin{array}{l}\text { Vaillant, } \\
\text { G. (2005) }\end{array}$ & $\begin{array}{l}\text { Conversation with George } \\
\text { Vaillant. Addiction. }\end{array}$ & $\begin{array}{l}\text { Entrevista } \\
\text { jornalística }\end{array}$ & $\begin{array}{l}\text { Não especi- } \\
\text { ficado }\end{array}$ & $\begin{array}{l}\text { Não especi- } \\
\text { ficada }\end{array}$ \\
\hline
\end{tabular}

Predominam nesse material os estudos voltados para o uso de substâncias (MATUSOW; ROSENBLUM, 2013; JOHNSON, 2011; DE RICK; VANHEULE; VERHAEGHE, 2009; VALENTINE; FRASER, 2008; DE RICK; VANHEULE, 2007), havendo um estudo dedicado à adicção sexual (ESTELLON; MOURAS, 2012) e um à adicção a jogos eletrônicos (ESSIG, 2012). O trabalho de Mann (2013) fornece referências bibliográficas relevantes e a etimologia da palavra adicção em várias línguas. Schubler (2014) apresenta em seu artigo uma revisão de um sistema diagnóstico psicodinâmico das adicções e contribui com uma sistematização de traços para a compreensão diagnóstica. Cinco trabalhos, mesmo baseados em referência psicanalítica, desenvolveram pesquisas sobre neurobiologia, numa articulação entre esses dois campos para pensar as adicções (JOHNSON, 2013, 2011; BAZAN; DETANDT, 2013; BERNER; BRIKEN, 2012; ESTELLON; MOURAS, 2012; GABBERT, 2009).

Dessas pesquisas, seis se debruçaram sobre questões teóricas (BENDAT, 2014; BAZAN; DETANDT, 2013; MANN, 2013; BERNER; BRIKEN, 2012; GABBERT, 2009), que abordam questões teórico-conceituais indiretamente relacionadas com o objeto deste estudo, como a relação entre Freud e Jung acerca da neurose obsessiva 
(KRADIN, 2014). O trabalho de Matusow e Rosenblum (2013) discute as teorias psicodinâmicas da adicção e suas proposições terapêuticas. Contribui com boas referências e revisão sobre as teorias. Cinco dos textos encontrados apresentaram a ocorrência da palavra adicção de forma periférica e se debruçam sobre aspectos predominantemente ligados a substancias (VAILLANT, 2005; PETERSEN et al., 2007; GABBERT, 2009; PRESS, 2005; BENDAT, 2014).

No geral, o levantamento nessa base de dados revelou uma grande influência biomédica sobre os trabalhos obtidos, além de escassos aportes de contribuições propriamente psicanalíticas para esse campo.

\subsection{REVISÃO DA BIBLIOTECA DIGITAL DE TESES E DISSERTAÇÕES DA USP}

Inaugurada em 2001, a Biblioteca Digital de Teses e Dissertações da Universidade de São Paulo tem o objetivo de facilitar o acesso a trabalhos de mestrado, doutorado e livre-docência produzidos por seus membros. Está associada a uma iniciativa global reconhecida pela Unesco, a Networked Digital Library of Theses and Dissertations (NDLTD), o que lhe garante maior confiabilidade e abrangência. Também se vincula ao Instituto Brasileiro de Informação em Ciência e Tecnologia (IBICT) do Ministério da Ciência e Tecnologia, através da Biblioteca Digital Brasileira de Teses e Dissertações. Permite acesso à versão digital completa dos documentos de forma rápida e fácil pela internet. 
Tabela 19. Palavras-chave pesquisadas na Biblioteca Digital de Teses e Dissertações da USP: "borderline", "borderline and psicanálise and adicção", "borderline and adicção", "borderline and psicanálise", "borderline and adição", "borderline and dependência"

\begin{tabular}{|lcc|}
\hline Palavra-chave & $\begin{array}{c}\text { Número de } \\
\text { Estudos 2014 }\end{array}$ & $\begin{array}{c}\text { Número de } \\
\text { Estudos } 2016\end{array}$ \\
\hline borderline & 5 & 5 \\
\hline borderline and psicanálise and adicção & 0 & 1 \\
\hline borderline and adicção & 0 & 7 \\
\hline borderline and psicanálise & 0 & 7 \\
\hline borderline and adição & 0 & 7 \\
\hline borderline and dependência & 0 & 6 \\
\hline
\end{tabular}

A pesquisa de trabalhos publicados na Biblioteca Digital de Teses e Dissertações da Universidade de São Paulo a partir da palavra-chave "borderline", revelou cinco estudos no total, tanto em 2014 como em 2016. Trata-se de produções bem recentes, realizadas nos últimos cinco. As palavras-chave "borderline and psicanálise and adicção" (e adição), "borderline and adicção", "borderline and psicanálise", "borderline and adição" $e$ "borderline and dependência" não geraram resultado algum em 2014. Em 2016, com as palavras-chave "borderline and psicanálise and adicção" (e adição) foram encontrados seis estudos; com o termo "borderline and adicção", apenas um trabalho; e com os termos "borderline and psicanálise", "borderline and adição" e "borderline and dependência", sete produções foram reveladas.

Tabela 20. Tema e metodologia dos artigos da Biblioteca Digital de Teses e Dissertações da USP sobre "borderline"

\begin{tabular}{lllll}
\hline Referência & Título & Método & Registro & Análise \\
\hline Mazer, A. K. & Diagnóstico diferencial entre & Quantitativo & $\begin{array}{l}\text { Prontuá- } \\
\text { rios indi- }\end{array}$ & Estatística \\
& transtorno afetivo bipolar e & & viduais e & \\
& transtorno de personalidade & banco de & \\
& borderline fundamentado na & dados & \\
& história de estresse precoce e & & \\
& em avaliação psiconeuroen- & & \\
& dócrina. & & \\
\hline
\end{tabular}




\begin{tabular}{|c|c|c|c|c|}
\hline $\begin{array}{l}\text { Cruz, M. } \\
(2012)\end{array}$ & $\begin{array}{l}\text { Reflexões sobre a relação } \\
\text { entre a personalidade border- } \\
\text { line e as adicções. }\end{array}$ & Estudo teórico & Narrativa & $\begin{array}{l}\text { Psicanalí- } \\
\text { tica }\end{array}$ \\
\hline $\begin{array}{l}\text { Daló, L. H. } \\
\text { O. (2012) }\end{array}$ & $\begin{array}{l}\text { A escrita dos estados-limite } \\
\text { como um recurso de amplia- } \\
\text { ção da escuta psicanalítica. }\end{array}$ & Estudo teórico & Narrativa & $\begin{array}{l}\text { Psicanalí- } \\
\text { tica }\end{array}$ \\
\hline $\begin{array}{l}\text { Kallas, } \\
\text { R.G.M. } \\
\text { (2012) }\end{array}$ & $\begin{array}{l}\text { Adicção a drogas e funcio- } \\
\text { namentos limites: suas ex- } \\
\text { pressões e convergências no } \\
\text { Rorschach. }\end{array}$ & $\begin{array}{l}\text { Estudo clínico } \\
\text { por meio da } \\
\text { aplicação do } \\
\text { teste projetivo } \\
\text { (Rorschach) }\end{array}$ & $\begin{array}{l}\text { Registro } \\
\text { de entre- } \\
\text { vista e das } \\
\text { respostas } \\
\text { ao teste de } \\
\text { Rorschach }\end{array}$ & $\begin{array}{l}\text { Classifica- } \\
\text { ção das } \\
\text { respostas } \\
\text { dos parti- } \\
\text { cipantes }\end{array}$ \\
\hline $\begin{array}{l}\text { Sadi, H.M. } \\
\text { (2011) }\end{array}$ & $\begin{array}{l}\text { Análise dos comportamentos } \\
\text { de terapeuta e cliente em um } \\
\text { caso de transtorno de perso- } \\
\text { nalidade borderline. }\end{array}$ & Estudo de caso & $\begin{array}{l}\text { Registro } \\
\text { de sessões }\end{array}$ & $\begin{array}{l}\text { Categori- } \\
\text { zação de } \\
\text { compor- } \\
\text { tamentos }\end{array}$ \\
\hline
\end{tabular}

A análise desse material permitiu a ampliação conceitual de referências e a atualização da compreensão desse campo. Três trabalhos se destacam pela contribuição para a presente pesquisa, todos defendidos no ano de 2012 (CRUZ, 2012; DALÓ, 2012; KALLAS, 2012). Daló (2012) faz uma ampla discussão e revisão sobre o conceito de estado-limite a partir de indagações psicanalíticas, tendo como ponto de partida principal o registro da clínica no atendimento desses casos. Assim, oferece acesso à compreensão de conceitos centrais para o presente estudo e amplia as referências bibliográficas pertinentes.

Os trabalhos de Cruz (2012) e Kallas (2012) tratam diretamente sobre o objeto da presente empreitada, que é decorrente da pesquisa de mestrado de Cruz (2012). Esse estudo, sobre a relação entre a personalidade borderline e as adicções, abriu caminho para um passo seguinte, a investigação da adiç̧ão ao outro nesses pacientes.

O estudo de Kallas (2012) consiste em fecunda revisão sobre a relação entre os pacientes fronteiriços e adictos. Além de Cruz (2012), foi o único a abordar psicanaliticamente essa relação, dentre todas as pesquisas extraídas das mencionadas bases de dados . É uma contribuição que traz referências, delimitações conceituais e um panorama atualizado sobre o tema psicanalítico em questão.

Os outros dois trabalhos (MAZER, 2013; SADI, 2011) versam sobre pacientes fronteiriços a partir de referências psiquiátricas e comportamentais, adotam estratégias 
metodológicas quantitativas e não se apresentam como referências significativas para o presente estudo, devido à distância do paradigma adotado nas pesquisas.

Tabela 21. Tema e Metodologia dos artigos da Biblioteca Digital de Teses e Dissertações da USP sobre "borderline and psicanálise and adicção"

\begin{tabular}{|c|c|c|c|c|}
\hline Referência & Título & Método & Registro & Análise \\
\hline $\begin{array}{l}\text { Garcia, } \\
\text { M.C.C.C. } \\
(2015)\end{array}$ & $\begin{array}{l}\text { Anorexia e bulimia na } \\
\text { clínica psicanalítica: um } \\
\text { estudo a partir da obra de } \\
\text { Didier Anzieu }\end{array}$ & $\begin{array}{l}\text { Demons- } \\
\text { tração } \\
\text { argumen- } \\
\text { tativa }\end{array}$ & $\begin{array}{l}\text { Não espe- } \\
\text { cificado }\end{array}$ & $\begin{array}{l}\text { Não especi- } \\
\text { ficada }\end{array}$ \\
\hline $\begin{array}{l}\text { Humberg, } \\
\text { L.V. (2014) }\end{array}$ & $\begin{array}{l}\text { Relacionamentos adictivos, } \\
\text { um estudo psicanalítico }\end{array}$ & $\begin{array}{l}\text { Estudo de } \\
\text { caso }\end{array}$ & $\begin{array}{l}\text { Não espe- } \\
\text { cificado }\end{array}$ & $\begin{array}{l}\text { Enfoque } \\
\text { psicanalíti- } \\
\text { co utilizado } \\
\text { para análise } \\
\text { dos dados }\end{array}$ \\
\hline $\begin{array}{l}\text { Pereira, D. R. } \\
(2013)\end{array}$ & $\begin{array}{l}\text { Aspectos da compulsão à } \\
\text { repetição na clínica psicana- } \\
\text { lítica: resistências e toxico- } \\
\text { mania }\end{array}$ & $\begin{array}{l}\text { Demons- } \\
\text { tração } \\
\text { argumen- } \\
\text { tativa }\end{array}$ & $\begin{array}{l}\text { Não espe- } \\
\text { cificado }\end{array}$ & $\begin{array}{l}\text { Não especi- } \\
\text { ficada }\end{array}$ \\
\hline $\begin{array}{l}\text { Dinamarco, } \\
\text { A.V. } \\
(2011)\end{array}$ & $\begin{array}{l}\text { Análise exploratória sobre o } \\
\text { sintoma de automutilação } \\
\text { praticada com objetos cor- } \\
\text { tantes e/ou perfurantes, } \\
\text { através de relatos expostos } \\
\text { na internet por um grupo } \\
\text { brasileiro que se define co- } \\
\text { mo praticante de automuti- } \\
\text { lação }\end{array}$ & $\begin{array}{l}\text { Pesquisa } \\
\text { de campo }\end{array}$ & $\begin{array}{l}\text { Não espe- } \\
\text { cificado }\end{array}$ & $\begin{array}{l}\text { Enfoque } \\
\text { psicanalíti- } \\
\text { co utilizado } \\
\text { para análise } \\
\text { dos dados }\end{array}$ \\
\hline $\begin{array}{l}\text { Junqueira, C. } \\
(2010)\end{array}$ & $\begin{array}{l}\text { Rumo à 'metapsicologia dos } \\
\text { limites': o diálogo possível } \\
\text { entre a teoria pulsional e a } \\
\text { teoria das relações de objeto } \\
\text { e algumas de suas conse- } \\
\text { quências - Freud, Winnicott } \\
\text { e Green }\end{array}$ & $\begin{array}{l}\text { Demons- } \\
\text { tração } \\
\text { argumen- } \\
\text { tativa }\end{array}$ & $\begin{array}{l}\text { Não espe- } \\
\text { cificado }\end{array}$ & $\begin{array}{l}\text { Não especi- } \\
\text { ficada }\end{array}$ \\
\hline $\begin{array}{l}\text { Munduruca, } \\
\text { G. (2008) }\end{array}$ & $\begin{array}{l}\text { Contribuição para o estudo } \\
\text { da constituição psíquica de } \\
\text { mulheres alcoolistas }\end{array}$ & $\begin{array}{l}\text { Pesquisa } \\
\text { de campo }\end{array}$ & $\begin{array}{l}\text { Não espe- } \\
\text { cificado }\end{array}$ & $\begin{array}{l}\text { Enfoque } \\
\text { psicanalíti- } \\
\text { co utilizado } \\
\text { para análise } \\
\text { dos dados }\end{array}$ \\
\hline
\end{tabular}


Todos os resultados dessa pesquisa constituem fontes relevantes devido à proximidade dos temas, à profundidade dos estudos e à qualidade metodológica. Por serem pesquisas de mestrado e doutorado, dão acesso a vasto material teórico, a conclusões pertinentes à presente investigação, assim como a referências importantes.

O trabalho de Garcia (2015) tem como perspectiva a hipótese de que os conceitos de Eu-Pele e de Envelopes Psíquicos, desenvolvidos pelo psicanalista Didier Anzieu, permitem compreender a constituição dos limites e fronteiras psíquicos nas patologias da anorexia e da bulimia na clínica psicanalítica. A autora traça um percurso pela obra de Didier Anzieu, a partir dos conceitos de Eu-Pele e Envelopes Psíquicos, a compreensão da teorização do autor acerca dos limites e fronteiras, que serão, posteriormente, articulados para os casos de anorexia e bulimia. Assim, a autora toca indiretamente no tema da adicção e do fronteiriço, em uma importante intersecção com as patologias alimentares.

O trabalho de Humberg (2014) consiste em referência fundamental para esta pesquisa. Aborda de forma central o objeto do trabalho e oferece sustentação para as formulações aqui construídas. A autora buscou compreender as características das relações adictivas ao estudar casos em que a relação conjugal é vivida como uma forma de adicção.

Pereira (2013) estuda a dimensão da compulsão à repetição, própria das adicções, mais especificamente abordada na toxicomania. Contribui com relevante revisão da concepção freudiana sobre o tema e oferece boas referências bibliográficas.

A pesquisa de Dinamarco (2011) versa sobre os significados presentes no ato de automutilação, compreendido psicanaliticamente. $\mathrm{O}$ objeto de estudo constitui-se a partir de informações e dos relatos expostos em uma rede de relacionamentos amplamente divulgada e de domínio público, o Orkut, por um grupo brasileiro que se denomina praticante de automutilação com objetos cortantes e perfurantes, sob o nome de Self-Mutilation Addicts. Trata-se de pesquisa de tema bastante novo e pouco explorado e que se cruza com o tema das adicções e dos pacientes fronteiriços. Traz referências essenciais, bem como reflexões sobre a cultura contemporânea.

Junqueira (2010) faz importante revisão sobre a teoria e o tratamento relacionados aos pacientes fronteiriços e oferece material teórico e referências significativas. 
Munduruca (2008), por sua vez, aborda o alcoolismo feminino a partir de trabalho de campo, caminhando por referências estruturalistas para discutir as determinações psíquicas da adicção ao álcool em mulheres. Ao se debruçar sobre o tema da adicção, oferece discussão relevante, assim como boas referências.

Tabela 22. Tema e metodologia dos artigos da Biblioteca Digital de Teses e Dissertações da USP sobre "borderline and adicção"

\begin{tabular}{|c|c|c|c|c|}
\hline Referência & Título & Método & Registro & Análise \\
\hline $\begin{array}{l}\text { Martins, } \\
\text { R.C. (2004) }\end{array}$ & $\begin{array}{l}\text { Psicodinâmica de usuários } \\
\text { de drogas: contribuições } \\
\text { da avaliação psicológica }\end{array}$ & $\begin{array}{l}\text { Pesquisa de cam- } \\
\text { po qualitativa }\end{array}$ & $\begin{array}{l}\text { Não espe- } \\
\text { cificado }\end{array}$ & $\begin{array}{l}\text { Psico- } \\
\text { métrica }\end{array}$ \\
\hline
\end{tabular}

Já Martins (2004) buscou avaliar as características psicológicas de usuários de drogas através de suas histórias de vida, desenvolvimento neuropsicomotor e dinâmica da personalidade. Foram pesquisados 20 homens de 18 a 35 anos: 10 usuários de drogas psicoativas (G1) por pelo menos um ano em busca de tratamento, recém-ingressos em internação institucional, e outros 10 participantes não usuários de drogas (G2), que integraram o grupo de controle. $\mathrm{O}$ trabalho é fundamentado em referências predominantemente psicométricas e não oferece muitos aportes para este trabalho devido à distância teórica e metodológica do olhar adotado para as questões abordadas em relação às opções ora escolhidas.

Tabela 23. Tema e metodologia dos artigos da Biblioteca Digital de Teses e Dissertações da USP sobre "borderline and psicanálise", "borderline and adição" e "borderline and dependência”

\begin{tabular}{|c|c|c|c|c|}
\hline Referência & Título & Método & Registro & Análise \\
\hline $\begin{array}{l}\text { Robert, P. F. } \\
\text { P. (2015) }\end{array}$ & $\begin{array}{l}\text { Da transferência negativa à } \\
\text { destrutividade: percursos } \\
\text { da clínica psicanalítica }\end{array}$ & $\begin{array}{l}\text { Demonstra- } \\
\text { ção argumen- } \\
\text { tativa }\end{array}$ & $\begin{array}{l}\text { Não especi- } \\
\text { ficado }\end{array}$ & $\begin{array}{l}\text { Não especi- } \\
\text { ficada }\end{array}$ \\
\hline $\begin{array}{l}\text { Mourão, M. } \\
\text { M. G. (2012) }\end{array}$ & $\begin{array}{l}\text { Da possibilidade do habi- } \\
\text { tar: o corpo como morada. } \\
\text { Corporeidade e formas } \\
\text { subjetivas contemporâneas }\end{array}$ & $\begin{array}{l}\text { Estudo teóri- } \\
\text { co }\end{array}$ & $\begin{array}{l}\text { Não especi- } \\
\text { ficado }\end{array}$ & $\begin{array}{l}\text { Não especi- } \\
\text { ficada }\end{array}$ \\
\hline $\begin{array}{l}\text { Queiroz, F. } \\
\text { C. A. (2011) }\end{array}$ & $\begin{array}{l}\text { Representação no campo do } \\
\text { traumático: A enfermidade } \\
\text { grave na infầncia e o impac- } \\
\text { to sobre o desenvolvimento }\end{array}$ & $\begin{array}{l}\text { Estudo teóri- } \\
\text { co-clínico }\end{array}$ & $\begin{array}{l}\text { Não especi- } \\
\text { ficado }\end{array}$ & $\begin{array}{l}\text { Psicanalíti- } \\
\text { ca }\end{array}$ \\
\hline
\end{tabular}




\begin{tabular}{|c|c|c|c|c|}
\hline $\begin{array}{l}\text { Roncolato, } \\
\text { A. A. }(2011)\end{array}$ & $\begin{array}{l}\text { Psicodiagnóstico compre- } \\
\text { ensivo de crianças com } \\
\text { distúrbios de conduta: as- } \\
\text { pectos psicodinâmicos }\end{array}$ & $\begin{array}{l}\text { Pesquisa de } \\
\text { campo }\end{array}$ & $\begin{array}{l}\text { Não especi- } \\
\text { ficado }\end{array}$ & $\begin{array}{l}\text { Enfoque } \\
\text { psicanalíti- } \\
\text { co utilizado } \\
\text { para análise } \\
\text { dos dados }\end{array}$ \\
\hline $\begin{array}{l}\text { Sophia, E. } \\
\text { C. }(2009)\end{array}$ & $\begin{array}{l}\text { Amor patológico: aspec- } \\
\text { tos clínicos e de personali- } \\
\text { dade }\end{array}$ & $\begin{array}{l}\text { Estudo quan- } \\
\text { titativo }\end{array}$ & $\begin{array}{l}\text { Não especi- } \\
\text { ficado }\end{array}$ & $\begin{array}{l}\text { Avaliação } \\
\text { estatística }\end{array}$ \\
\hline $\begin{array}{l}\text { Kallas, R. G. } \\
\text { M. (2007) }\end{array}$ & $\begin{array}{l}\text { Do psicodiagnóstico à } \\
\text { intervenção em adictos: } \\
\text { Contribuições do } \\
\text { Rorschach e do atendi- } \\
\text { mento clínico }\end{array}$ & $\begin{array}{l}\text { Pesquisa de } \\
\text { campo }\end{array}$ & $\begin{array}{l}\text { Não especi- } \\
\text { ficado }\end{array}$ & $\begin{array}{l}\text { Enfoque } \\
\text { psicanalíti- } \\
\text { co utilizado } \\
\text { para análise } \\
\text { dos dados }\end{array}$ \\
\hline $\begin{array}{l}\text { Humberg, L. } \\
\text { V. (2003) }\end{array}$ & $\begin{array}{l}\text { Dependência do vínculo: } \\
\text { uma releitura do conceito } \\
\text { de codependência }\end{array}$ & $\begin{array}{l}\text { Pesquisa de } \\
\text { campo }\end{array}$ & $\begin{array}{l}\text { Não especi- } \\
\text { ficado }\end{array}$ & $\begin{array}{l}\text { Enfoque } \\
\text { psicanalíti- } \\
\text { co utilizado } \\
\text { para análise } \\
\text { dos dados }\end{array}$ \\
\hline
\end{tabular}

Os resultados obtidos com os descritores "borderline and psicanálise", "borderline and adição" e "borderline and dependência" levaram a sete ocorrências. São, em geral, investigações bastante relevantes e consistentes, algumas não tão ligadas diretamente ao tema da pesquisa, mas não menos úteis (ROBERT, 2015; MOURÃO, 2012; QUEIROZ, 2011; RONCOLATO, 2011; SOPHIA, 2009). Por outro lado, dois trabalhos, de Kallas (2007) e Humberg (2003), se aproximam bastante da presente pesquisa e oferecem material importante.

Humberg (2003) parte das hipóteses de que os familiares de dependentes químicos também apresentariam uma dependência, não das drogas, mas do vínculo estabelecido nessa relação, e que tal adicção não seria restrita somente a esses familiares. Para testar as hipóteses, a autora realizou uma revisão bibliográfica do conceito de codependência e uma pesquisa embasada no referencial psicanalítico. Os resultados indicam a comprovação de sua hipótese sobre a existência de uma relação de "dependência do vínculo" por parte dos familiares, como nomeou a autora.

Kallas (2007) apresenta revisão de estudos com pacientes adictos que demonstram que, embora não exista uma estrutura psíquica estável e profunda, específica dos comportamentos de dependência, alguns aspectos são recorrentes nesses pacientes. A 
autora destaca a incapacidade para pensar, refletir, adiar, bem como a substituição dessas habilidades pela ação; a profunda vivência de vazio existencial, uma constante demanda por preenchimento e busca de um objeto mágico, exterior, capaz de aliviar a angústia existencial; precária capacidade de integrarem as imagens parentais que poderiam servir de modelos identificatórios; prejuízo das identificações ulteriores e, portanto, do estabelecimento de relações duradouras; além de uma grande dificuldade no processo de identificação sexual. A autora pesquisou, por meio de cinco estudos de caso de pacientes drogadictos, as características próprias da dinâmica afetiva desses indivíduos, expressas no Método de Rorschach e no processo de atendimento psicológico. O trabalho consiste em referência fundamental para esta pesquisa, pois aborda diretamente a relação ora estudada.

Tabela 24. Palavras-chave pesquisadas na Biblioteca Digital de Teses e Dissertações da USP: "fronteiriço", "fronteiriço and psicanálise and adicção", "fronteiriço and adicção", "fronteiriço and psicanálise", "fronteiriço and adição", "fronteiriço and dependência"

\begin{tabular}{|lcc|}
\hline Palavra-chave & $\begin{array}{c}\text { Número de } \\
\text { Estudos 2014 }\end{array}$ & $\begin{array}{c}\text { Número de } \\
\text { Estudos 2016 }\end{array}$ \\
\hline fronteiriço & 0 & 0 \\
\hline fronteiriço and psicanálise and adicção & 0 & 0 \\
\hline fronteiriço and adicção & 0 & 0 \\
\hline fronteiriço and psicanálise & 0 & 1 \\
\hline fronteiriço and adição & 0 & 0 \\
\hline fronteiriço and dependência & 0 & 0 \\
\hline
\end{tabular}

A busca pela palavra "fronteiriço" na Biblioteca Digital de Teses e Dissertações da USP também revelou duas pesquisas que não foram incluídas na tabela, por se referirem ao conceito de fronteira em outros contextos muito distantes, no caso, geografia humana e ciência ambiental.

Partindo dos termos "fronteiriço and psicanálise and adicção", "fronteiriço and adicção", "fronteiriço and adição" e "fronteiriço and dependência", a pesquisa não localizou nenhum resultado. Já a busca por "fronteiriço and psicanálise” gerou um resultado. 
Tabela 25. Tema e metodologia dos artigos da Biblioteca Digital de Teses e Dissertações da USP sobre "fronteiriço and psicanálise"

\begin{tabular}{lllll}
\hline Referência & Título & Método & Registro & Análise \\
\hline Moreno, M. & Trauma precoce e ligações psí- & Estudo & Não espe- & Não espe- \\
M. A. (2004) & quicas, um estudo psicanalítico & teórico & cificado & cificado \\
\hline
\end{tabular}

Moreno (2004) contribui com uma consistente construção sobre as ressonâncias do traumatismo precoce e das defesas por este suscitadas no processo de simbolização primária, especialmente nas ligações psíquicas decorrentes e na construção de sentido inconsciente. Segundo a autora, os conceitos de trauma precoce e simbolização primária se entrelaçam na trama complexa da constituição psíquica, que se suplementa, em tensão paradoxal, entre os polos intersubjetivo e intrapsíquico. As discussões se articulam entre as proposições inaugurais de Freud e Ferenczi e seus desdobramentos na teoria psicanalítica pósfreudiana, particularmente nas obras de Donald Winnicott, André Green e René Roussillon.

A pesquisa oferece subsídios importantes para a compreensão das adicções e do paciente fronteiriço, principalmente das falhas na simbolização marcadamente presentes nessas manifestações. As articulações teóricas da autora fornecem contribuições à metapsicologia dos processos psíquicos inaugurais, constitutivos e traumáticos, assim como subsídios ao pensamento clínico/psicopatológico em psicanálise.

Tabela 26. Palavras-chave pesquisadas na Biblioteca Digital de Teses e Dissertações da USP: "estados limite", "estados-limite and psicanálise", "estados-limite and psicanálise and adicção", "estados-limite", "casos-limite", "casos limite", "caso limite"

\begin{tabular}{|lcc|}
\hline Palavra-chave & $\begin{array}{c}\text { Número de } \\
\text { Estudos 2014 }\end{array}$ & $\begin{array}{c}\text { Número de } \\
\text { Estudos 2016 }\end{array}$ \\
\hline estados limite & 0 & 9 \\
\hline estados-limite and psicanálise & 0 & 9 \\
\hline estados-limite and psicanálise and adicção & 0 & 9 \\
\hline estados-limite & 0 & 9 \\
\hline casos-limite & 0 & 4 \\
\hline casos limite & 0 & 4 \\
\hline caso limite & 0 & 4 \\
\hline
\end{tabular}


A busca pela expressão "estados limite” em 2014, na Biblioteca Digital de Teses e Dissertações da USP, revelou dois estudos, porém ambos da área de estrutura, defendidos na unidade de engenharia. Por esse motivo, não foram incluídos na Tabela 26. Ao procurar pelas palavras "estados-limite and psicanálise", "estados-limite and psicanálise and adicção", "estados-limite", "casos-limite", "casos limite" e "caso limite" não foram encontrados resultados. Em 2016 a busca com esses termos revelou, ao todo, nove trabalhos, já incluídos anteriormente: Garcia (2015), Humberg (2014), Pereira (2013), Cruz (2012), Daló (2012), Mourão (2012), Kallas (2012), Junqueira (2010) e Humberg (2003).

Tabela 27. Outras palavras-chave pesquisadas na Biblioteca Digital de Teses e Dissertações da USP

\begin{tabular}{|lcc|}
\hline Palavra-chave & $\begin{array}{c}\text { Número de } \\
\text { Estudos } \\
2014\end{array}$ & $\begin{array}{c}\text { Número de } \\
\text { Estudos } \\
2016\end{array}$ \\
\hline $\begin{array}{l}\text { transtorno de personalidade limítrofe } \\
\text { CID-10 }\end{array}$ & 0 & 7 \\
\hline $\begin{array}{l}\text { transtorno de personalidade borderline } \\
\text { DSM-IV/ DSM-V }\end{array}$ & 1 & 0 \\
\hline $\begin{array}{l}\text { transtorno de personalidade emocionalmente instável } \\
\text { CID-10 }\end{array}$ & 0 & 0 \\
\hline $\begin{array}{l}\text { transtorno de personalidade borderline and psicanáli- } \\
\text { se }\end{array}$ & 0 & 0 \\
\hline $\begin{array}{l}\text { transtorno de personalidade borderline and psicanáli- } \\
\text { se and adicção }\end{array}$ & 0 & 0 \\
\hline $\begin{array}{l}\text { transtorno de personalidade borderline and psicanáli- } \\
\text { se and adição }\end{array}$ & 0 & 0 \\
\hline $\begin{array}{l}\text { transtorno de personalidade borderline and depen- } \\
\text { dência }\end{array}$ & 0 & 0 \\
\hline
\end{tabular}

Ao procurar pela expressão "transtorno de personalidade borderline", localizou-se apenas um resultado em 2014. Como ele já havia sido encontrado e discutido na Tabela 20 (MAZER, 2013), não será aqui abordado. Com as expressões "transtorno de personalidade limítrofe", "transtorno de personalidade emocionalmente instável", 
"transtorno de personalidade borderline and psicanálise", "transtorno de personalidade borderline and psicanálise and adicção", "transtorno de personalidade borderline and psicanálise and adição" e "transtorno de personalidade borderline and dependência" não foram localizados estudos. A pesquisa de 2016 forneceu, ao todo, sete ocorrências repetidas, já incluídas anteriormente, que constituem trabalhos relevantes para a pesquisa: Pereira (2013), Cruz (2012), Kallas (2012), Roncolatto (2011), Sadi (2011), Sophia (2009) e Humberg (2003). Foram localizados diversos resultados distantes dos objetivos desta pesquisa, relacionados a trabalhos dos campos da neurobiologia, psicoterapia comportamental e temas diversos da psiquiatria.

\subsection{REVISÃO DO PORTAL DE PERIÓdICOS DA CAPES}

O Portal de Periódicos da Coordenação de Aperfeiçoamento de Pessoal de Nível Superior (Capes) é uma biblioteca virtual que reúne e disponibiliza a instituições de ensino e pesquisa no Brasil o melhor da produção científica internacional. Ele conta com um acervo de mais de 37 mil títulos com texto completo, 126 bases referenciais, 11 bases dedicadas exclusivamente a patentes, além de livros, enciclopédias e obras de referência, normas técnicas, estatísticas e conteúdo audiovisual.

O Portal de Periódicos foi elaborado tendo em vista a deficiência de acesso das bibliotecas brasileiras à informação científica internacional, segundo a perspectiva de que seria excessivamente caro atualizar esse acervo com a compra de periódicos impressos para cada uma das universidades do sistema superior de ensino federal. Foi desenvolvido também com o objetivo de reduzir os desnivelamentos regionais no acesso a essa informação no Brasil. Considerado um modelo de consórcio de bibliotecas único no mundo, por ser inteiramente financiado pelo governo brasileiro, é também a iniciativa do gênero com a maior capilaridade no planeta, cobrindo todo o território nacional.

O Portal de Periódicos atende às demandas dos setores acadêmico, produtivo e governamental e propicia o aumento da produção científica nacional e o crescimento da inserção científica brasileira no exterior. Constitui, portanto, uma ferramenta fundamental às atribuições da Capes de fomento, avaliação e regulação dos cursos de pósgraduação e desenvolvimento da pesquisa científica no Brasil. 
Tabela 28. Palavras-chave pesquisadas no Portal de Periódicos da Capes: "borderline", "borderline and psicanálise and adicção", "borderline and adicção", "borderline and psicanálise", "borderline and psychoanalysis", "borderline and addiction", "borderline and adição", "borderline and dependência"

\begin{tabular}{|lc|}
\hline Palavra-chave & $\begin{array}{c}\text { Número de } \\
\text { Estudos 2016 }\end{array}$ \\
\hline borderline & 29.916 \\
\hline borderline and psicanálise and adicção & 3 \\
\hline borderline and adicção & 1 \\
\hline borderline and psicanálise & 60 \\
\hline borderline and psychoanalysis & 151 \\
\hline borderline and addiction & 310 \\
\hline borderline and adição & 6 \\
\hline borderline and dependência & 21 \\
\hline
\end{tabular}

O levantamento por publicações no Portal de Periódicos da Capes ocorreu, inicialmente, a partir da palavra-chave "borderline”, que forneceu 29.916 resultados. Frente à quantidade elevada de artigos, refinou-se a busca. Os termos "borderline and psicanálise and adicção" geraram três ocorrências; "borderline and adicção" produziu um resultado; "borderline and psicanálise" proporcionou sessenta ocorrências; "borderline and psychoanalysis", 151 resultados; "borderline and addiction", 310 resultados; "borderline and adição", seis ocorrências; e "borderline and dependência", 21 respostas.

Serão apresentadas apenas as referências que mais se aproximam dos objetivos desta pesquisa; as demais serão excluídas. Grande parte das ocorrências com as palavras-chave apresentadas abordam temas relacionados a suicídio, epidemiologia, neurobiologia, psicofarmacologia, validação de escalas, avaliação de modelos psicoterapêuticos, literatura, câncer, HIV, hipertensão e criminalidade. Com as palavras "borderline" e "borderline and psicanálise and adicção" e "borderline and adicção" foram encontrados três trabalhos já apresentados anteriormente, de Cruz (2012), Kallas (2012) e Nunes Silva (2009). Com os termos "borderline and dependência" foram localizados os trabalhos de Portela de Carvalho (2013), discutido na Tabela 5, e de Kallas (2012), elencado 
na Tabela 20. O estudo de Salomone (2009) foi selecionado, entre diversos resultados de menor relevância, segundo o critério de proximidade com os objetivos da presente pesquisa, e será discutido a seguir na Tabela 29.

Tabela 29. Tema e metodologia dos artigos do Portal de Periódicos da Capes sobre "borderline and psicanálise"

\begin{tabular}{lllll}
\hline Referência & Título & Método & Registro & Análise \\
\hline $\begin{array}{l}\text { Salomone, } \\
\text { V.P. D. }\end{array}$ & $\begin{array}{l}\text { Contribuições de D. W. Win- } \\
\text { nicott para o estudo do distúrbio } \\
\text { (2009) }\end{array}$ & $\begin{array}{l}\text { Estudo } \\
\text { teórico } \\
\text { clínicas }\end{array}$ & $\begin{array}{l}\text { Não espe- } \\
\text { cificado }\end{array}$ & $\begin{array}{l}\text { Não espe- } \\
\text { cificada }\end{array}$ \\
& & & & \\
\hline
\end{tabular}

A dissertação de mestrado de Salomone (2009) apresenta a compreensão winnicottiana sobre o distúrbio borderline, investigando não apenas a maneira pela qual o falso Self se forma como defesa nesses casos, mas se debruçando também sobre o manejo clínico. Além da revisão sobre a origem do termo borderline na psiquiatria, fornece algumas contribuições de autores da psicanálise para a compreensão do quadro, com destaque para as de Winnicott. Trata-se de trabalho fundamental para a presente pesquisa pela proximidade do tema e das referências teóricas em relação ao objeto deste estudo.

Além do trabalho de Salomone (2009), a busca pela palavra-chave "borderline and psicanálise" localizou sete ocorrências já apresentadas em outras pesquisas. Tratase das produções de Daló (2012), Carvalho (2011), Jordão (2010), Junqueira (2010), Lionço (2008), Vidal (2008) e Junqueira (2006).

Tabela 30. Tema e Metodologia dos artigos do Portal de Periódicos da Capes sobre "borderline and psychoanalysis"

\begin{tabular}{lllll}
\hline Referência & Título & Método & Registro & Análise \\
\hline $\begin{array}{l}\text { Londoño } \\
\text { Paredes, } \\
\text { D. E. (2015) }\end{array}$ & $\begin{array}{l}\text { Elucidación epistémi- } \\
\text { ca e histórica del tras- } \\
\text { torno de la personali- } \\
\text { dad límite o borderline }\end{array}$ & $\begin{array}{l}\text { Demonstração } \\
\text { argumentativa }\end{array}$ & $\begin{array}{l}\text { Não espe- } \\
\text { cificado }\end{array}$ & $\begin{array}{l}\text { Não espe- } \\
\text { cificada }\end{array}$ \\
$\begin{array}{l}\text { Lunbeck, E. } \\
\text { (2006) }\end{array}$ & $\begin{array}{l}\text { Borderline histories: } \\
\text { psychoanalysis inside } \\
\text { and out }\end{array}$ & $\begin{array}{l}\text { Demonstração } \\
\text { argumentativa }\end{array}$ & $\begin{array}{l}\text { Não espe- } \\
\text { cificado }\end{array}$ & $\begin{array}{l}\text { Não espe- } \\
\text { cificada }\end{array}$ \\
\hline
\end{tabular}




\begin{tabular}{|c|c|c|c|c|}
\hline $\begin{array}{l}\text { Figueiredo, L. } \\
\text { C. M. (2006) }\end{array}$ & $\begin{array}{l}\text { Sense of reality, reality } \\
\text { testing and reality pro- } \\
\text { cessing in borderline } \\
\text { patients. }\end{array}$ & Estudo teórico & $\begin{array}{l}\text { Não espe- } \\
\text { cificado }\end{array}$ & $\begin{array}{l}\text { Psicanalí- } \\
\text { tica }\end{array}$ \\
\hline $\begin{array}{l}\text { Bradley, R.; } \\
\text { Westen, D. } \\
(2005)\end{array}$ & $\begin{array}{l}\text { The psychodynamics } \\
\text { of borderline personal- } \\
\text { ity disorder: A view } \\
\text { from developmental } \\
\text { psychopathology }\end{array}$ & $\begin{array}{l}\text { Demonstração } \\
\text { argumentativa }\end{array}$ & $\begin{array}{l}\text { Não espe- } \\
\text { cificado }\end{array}$ & $\begin{array}{l}\text { Não espe- } \\
\text { cificada }\end{array}$ \\
\hline $\begin{array}{l}\text { Tramantano, } \\
\text { G.; Javier, R. } \\
\text { A.; Colon, M. } \\
\text { (2003) }\end{array}$ & $\begin{array}{l}\text { Discriminating among } \\
\text { subgroups of border- } \\
\text { line personality disor- } \\
\text { der: An assessment of } \\
\text { object representations }\end{array}$ & $\begin{array}{l}\text { Estudo quanti- } \\
\text { tativo }\end{array}$ & $\begin{array}{l}\text { Não espe- } \\
\text { cificado }\end{array}$ & $\begin{array}{l}\text { Psicanalí- } \\
\text { tica }\end{array}$ \\
\hline $\begin{array}{l}\text { Holmes, J. } \\
\text { (2003) }\end{array}$ & $\begin{array}{l}\text { Borderline personality } \\
\text { disorder and the search } \\
\text { for meaning: an at- } \\
\text { tachment perspective }\end{array}$ & Estudo clínico & $\begin{array}{l}\text { Não espe- } \\
\text { cificado }\end{array}$ & $\begin{array}{l}\text { Enfoque } \\
\text { psicanalíti- } \\
\text { co utiliza- } \\
\text { do para } \\
\text { análise dos } \\
\text { dados }\end{array}$ \\
\hline
\end{tabular}

Os resultados obtidos com as palavras-chave "borderline and psychoanalysis" levaram a seis trabalhos relevantes para a presente pesquisa. Trata-se de produções que se aproximam do tema estudado e representam fontes bastante fecundas e afinadas com a orientação teórica deste estudo. Dentre os resultados, o mais recente é o de Londoño (2015). O autor busca reconstituir a origem do conceito de "fronteiriço", epistemológica e historicamente enraizado, em psiquiatria e psicanálise. Oferece boas referências e perspectiva histórica do conceito. Lunbeck (2006) problematiza a existência do paciente fronteiriço como categoria e oferece um contraponto a esta construção.

O trabalho de Figueiredo (2006) constitui importante referência, sobretudo por tocar no tema do teste de realidade, assunto abordado nesta pesquisa. $\mathrm{O}$ autor defende que pacientes borderline não só realizam testes de realidade, como podem fazê-lo de forma repetida e frequente. Sugere hipóteses para essa situação e enfatiza a importância da posição depressiva e da travessia do Édipo para o estabelecimento de um senso de realidade capaz de propiciar o processamento de realidade consistente.

O artigo de Bradley e Westen (2005) fornece uma visão contemporânea da psicodinâmica do transtorno de personalidade borderline, de uma perspectiva da psicopa- 
tologia do desenvolvimento. Aborda a evolução da construção do paciente borderline na psicanálise e psiquiatria, assim como teorias dinâmicas proeminentes da etiologia da personalidade borderline e alguns modelos de tratamento.

O objetivo do estudo de Tramantano, Javier e Colon (2003) foi identificar subgrupos de transtorno de personalidade borderline, examinando as relações de objeto internalizadas. Para tanto, os autores adotaram a metodologia psicométrica com análise qualitativa e psicodinâmica. Os resultados sugerem que o objeto interno mau de pacientes borderline é fundamentalmente diferente de pacientes psiquiátricos não borderline. Os autores buscaram identificar subtipos de transtorno borderline de personalidade com o objetivo de discriminar mais precisamente o transtorno borderline de outros transtornos, assim como fornecer informações terapêuticas e prognóstico para os diferentes subgrupos de pacientes limítrofes. Trata-se de uma pesquisa baseada em testes e escalas, analisada psicanaliticamente. Apesar de tomar como referência o transtorno de personalidade borderline, o trabalho faz bons aportes psicanalíticos e oferece ricas referências.

Por fim, o artigo de Holmes (2003) explora as ligações entre o conceito de apego desorganizado e o diagnóstico psiquiátrico de transtorno de personalidade borderline. Para o autor, as relações interpessoais nesses casos, inclusive com terapeutas ou cuidadores, constituem um dilema que se manifesta nas interações de transferência e contratransferência. $\mathrm{O}$ ato, ressalta Holmes, resulta da impossibilidade de comunicação e intimidade.

Tabela 31. Tema e metodologia dos artigos do Portal de Periódicos da Capes sobre "borderline and addiction"

\begin{tabular}{lllll}
\hline Referência & Título & Método & Registro & Análise \\
\hline Dalbudak, & The severity of Internet addiction & Estudo & escalas & Análise \\
A. et al. & risk and its relationship with the & quantita- & & $\begin{array}{l}\text { estatís- } \\
\text { (2014) }\end{array}$ \\
$\begin{array}{l}\text { severity of borderline personality } \\
\text { features, childhood traumas, dissoci- } \\
\text { ative experiences, depression and } \\
\text { anxiety symptoms among Turkish } \\
\text { university students }\end{array}$ & & & \\
& & & \\
\hline
\end{tabular}

O objetivo do estudo de Dalbudak et al. (2014) foi investigar a relação de dependência da internet com características de personalidade borderline, traumas de infância, experiências dissociativas, depressão e sintomas de ansiedade entre os estudantes 
universitários turcos. Um total de 271 sujeitos participaram da pesquisa. Os alunos foram avaliados através da Escala de Dependência da Internet (IAS), o Inventário de Personalidade Borderline (BPI), Dissociative Experiences Scale (DES), a Childhood Trauma Questionnaire (CTQ-28), o Beck Depression Inventory (BDI) e a Beck Anxiety Inventory $(\mathrm{BAI})$. As taxas foram de $19,9 \%(\mathrm{n}=54)$ dos estudantes no grupo de alto risco IA de dependência à internet, 38,7\% $(\mathrm{n}=105)$ no grupo de risco IA leve e $41,3 \%(\mathrm{n}=$ 112) no grupo sem risco IA. As análises de correlação com o BPI, a DES, o CTQ-28, o BDI e o BAI revelaram que a gravidade do risco de dependência à internet foi relacionada com a personalidade borderline e com experiências dissociativas, abuso emocional, trauma de infầncia, depressão e ansiedade. Análise de covariância univariada (ANCOVA) indicou que a gravidade das características de personalidade limítrofe, abuso emocional, depressão e ansiedade foram os preditores de pontuação IAS, enquanto que o gênero não teve efeito nessa pontuação. Entre os tipos de trauma de infầncia, o abuso emocional parece ser o principal preditor de gravidade de risco IA. Características de personalidade borderline indicaram maior gravidade do risco de IA, juntamente com abuso emocional, sintomas de depressão e ansiedade entre os estudantes universitários turcos.

Embora o estudo seja quantitativo, aborda tema bastante caro à presente pesquisa. A busca adictiva da internet e redes sociais como acesso ao outro de forma desesperada, marcada por vias narcísicas de um outro etéreo e essencial.

Além do artigo mencionado, foram encontrados os trabalhos de Cruz (2012) e Kallas (2012), apresentados na Tabela 20.

Tabela 32. Outras palavras-chave pesquisadas no Portal de Periódicos da Capes

\section{Palavra-chave}

\begin{tabular}{|l} 
fronteiriço \\
\hline fronteiriço and psicanálise and adicção \\
\hline
\end{tabular}

fronteiriço and adicção

fronteiriço and psicanálise

fronteiriço and adição

fronteiriço and dependência
Número de

Estudos 2016

67

0

0

2

1

11 
A busca pelo termo "fronteiriço" no Portal de Periódicos da Capes resultou em 67 ocorrências. Nenhuma corresponde ao campo da saúde mental, tampouco se aproxima do tema pesquisado. Foram levantados trabalhos das áreas da literatura, jornalismo, geografia, sociologia, linguística e oncologia.

Com as palavras-chave "fronteiriço and psicanálise and adicção" e "fronteiriço and adicção", não houve resultados. Os termos "fronteiriço and psicanálise" geraram dois resultados, apenas um relacionado ao campo da saúde mental (LIONÇO, 2008) e já apresentado na Tabela 4.

Os termos "fronteiriço and adição" forneceram apenas um resultado, irrelevante para este estudo, relacionado a outra área. As palavras "fronteiriço and dependência" geraram onze ocorrências, porém todas de outros campos e sem importância para esta pesquisa.

Tabela 33. Palavras-chave pesquisadas no Portal de Periódicos da Capes: "estados limite", "estados-limite and psicanálise", "estados-limite and psicanálise and adicção", "estados-limite", "casos-limite", "casos limite", "caso limite"

\begin{tabular}{|lc|}
\hline Palavra-chave & $\begin{array}{c}\text { Número de } \\
\text { Estudos 2016 }\end{array}$ \\
\hline estados limite & 341 \\
\hline estados-limite and psicanálise & 3 \\
\hline estados-limite and psicanálise and adicção & 0 \\
\hline estados-limite & 16 \\
\hline casos-limite & 16 \\
\hline casos limite & 852 \\
\hline caso limite & 1267 \\
\hline
\end{tabular}

As buscas realizadas com os termos "estados limite", "casos limite" e suas variações ortográficas, bem como "estados-limite and psicanálise" e "estados-limite and psicanálise and adicção", apresentaram inúmeros resultados distantes do campo da psicologia, psicanálise e saúde mental. A maior parte das ocorrências estava relacionada 
aos campos da engenharia civil e ambiental, física, matemática, lógica, geometria, geologia, geografia e agronomia, entre outras.

Entre os resultados mais próximos dos objetivos do presente trabalho estão estudos relacionados à eficácia de modelos psicoterapêuticos, principalmente da abordagem analítico-comportamental, ainda fora do campo de interesse deste estudo.

As buscas realizadas com os termos "estados-limite and psicanálise" e "caso limite" encontraram três trabalhos já apresentados: Daló (2012), elencado na Tabela 20; Portela de Carvalho (2011), apresentado na Tabela 5; e Junqueira (2010), mencionado na Tabela 21. Com os termos "estados-limite" e "casos-limite", além dessas três referências, foram encontrados os trabalhos de Cruz e Viana (2012), Chagnon (2009) e Pimentel e Coelho Júnior (2009), apresentados nas Tabelas 12, 4 e 13, respectivamente. Com as palavras "estados-limite and psicanálise and adicção", não houve resultados.

Os dois textos (CARDOSO, 2007; LÓPEZ et al., 2004) diretamente relacionados ao tema da pesquisa correspondem a uma pequena parte das ocorrências e serão apresentados a seguir.

Tabela 34. Tema e metodologia dos artigos do Portal de Periódicos da Capes sobre "estados limite"

\begin{tabular}{lllll}
\hline Referência & Título & Método & Registro & Análise \\
\hline $\begin{array}{l}\text { Cardoso, M. } \\
\text { R. (2007) }\end{array}$ & $\begin{array}{l}\text { A impossível "perda" do ou- } \\
\text { tro nos estados limites: explo- } \\
\text { rando as noções de limite e } \\
\text { alteridade }\end{array}$ & $\begin{array}{l}\text { Demonstração } \\
\text { argumentativa }\end{array}$ & $\begin{array}{l}\text { Não espe- } \\
\text { cificado }\end{array}$ & $\begin{array}{l}\text { Psica- } \\
\text { nalítica }\end{array}$ \\
López, D. et & $\begin{array}{l}\text { Psicoterápia focalizada en la } \\
\text { transferencia para el transtor- } \\
\text { al. (2004) }\end{array}$ & Estudo clínico & $\begin{array}{l}\text { Não espe- } \\
\text { cificado }\end{array}$ & $\begin{array}{l}\text { Estatís- } \\
\text { tica }\end{array}$ \\
& $\begin{array}{l}\text { Un límite de la personalidad. } \\
\text { meninas }\end{array}$ & & \\
& & & & \\
\hline
\end{tabular}

Os resultados significativos obtidos com as palavras-chave "estados limite" no Portal de Periódicos da Capes compuseram sete trabalhos, sendo apenas dois deles inéditos, por ora, nesta revisão. Entre os estudos já mencionados estão os de Londoño Paredes (2014), apresentado na Tabela 30; Cruz e Viana (2012), exposto na Tabela 12; Daló (2012), mencionado na Tabela 20; e Chagnon (2009), localizado na tabela 4. 
Dentre as ocorrências, destaca-se o trabalho de Cardoso (2007). A autora examina o modo de funcionamento psíquico próprio dos estados-limite e destaca o papel singular da dimensão de alteridade nesses casos. Expõe a complexa relação entre interioridade e exterioridade que caracteriza essas patologias, marcadas por uma problemática identitário-narcísica. O estudo estabelece um contraponto dos estados-limite com outros quadros clínicos, com o propósito de melhor precisar sua singularidade. É um trabalho de importância central para esta pesquisa, por abordar o tema dos estadoslimite com foco na questão da alteridade, problema fundante nesses casos.

O artigo de López et al. (2004) teve o objetivo de observar alterações na psicopatologia das mulheres com transtorno de personalidade borderline tratadas com 48 sessões de psicoterapia focada na transferência (PFT), aplicadas por terapeutas novatos, gravadas em vídeo e supervisionadas por especialistas. A PFT é uma psicoterapia específica para o transtorno borderline, sistematizada por Kernberg e colaboradores (2006) em conformidade com os requisitos do Instituto Nacional de Saúde Mental da América, sendo aplicada em duas sessões individuais por semana. Apesar de ser quantitativo e apresentar resultados voltados à eficácia da psicoterapia, o trabalho oferece breve discussão psicopatológica e excelentes referências bibliográficas.

Tabela 35. Tema e metodologia dos artigos do Portal de Periódicos da Capes sobre "casos limite"

\begin{tabular}{lllll}
\hline Referência & Título & Método & Registro & Análise \\
\hline Pérez, I. T.; Río & Trastorno límite de per- & Estudo & escalas & Análise \\
Sánchez, C. D.; & sonalidad según el & quantitativo & & estatística \\
Borda Mas, C. & MCMI-II en la anorexia y & & & \\
$(\mathbf{2 0 0 8 )}$ & bulimia nerviosas & & & \\
\hline
\end{tabular}

O trabalho de Pérez, Río Sánchez e Borda Mas (2008) tem o objetivo de estudar os traços de personalidade e o possível diagnóstico de transtorno de personalidade borderline em diferentes grupos de mulheres. Os autores pesquisaram 93 pacientes: 31 com anorexia nervosa restritiva (ANR), 31 com compulsivo-nervosa / anorexia purgante (ANP) e 31 com purga e bulimia nervosa (BNP). Além desses 93 sujeitos, 31 mulheres em risco de desenvolver um transtorno de comportamento alimentar compuseram o grupo-controle sintomático, e outras 31 mulheres sem patologia conhecida formaram o grupo de controle assintomático. Os pesquisadores concluíram que, a partir das escalas 
aplicadas e sua análise, as mulheres apresentaram mais traços borderline possíveis. Embora o trabalho indique resultado epidemiológico, a correlação e discussão sobre pacientes fronteiriços e transtornos alimentares corresponde a uma questão importante para o presente estudo. Além desse artigo, foram localizados mais dois trabalhos com os termos "casos limite". Trata-se dos artigos de Londoño Paredes (2014) e de García Lopéz (2010), apresentado nas Tabelas 30 e 13, respectivamente.

Tabela 36. Outras palavras-chave pesquisadas no Portal de Periódicos da Capes

\begin{tabular}{|l|l|}
\hline Palavra-chave & $\begin{array}{c}\text { Número de } \\
\text { Estudos 2016 }\end{array}$ \\
\hline $\begin{array}{l}\text { transtorno de personalidade borderline } \\
\text { DSM-IV/ DSM-V }\end{array}$ & 25 \\
\hline $\begin{array}{l}\text { transtorno de personalidade limítrofe } \\
\text { CID-10 }\end{array}$ & 1 \\
\hline $\begin{array}{l}\text { transtorno de personalidade emocionalmente instável } \\
\text { CID-10 }\end{array}$ & 2 \\
\hline $\begin{array}{l}\text { transtorno de personalidade borderline and psicanálise } \\
\text { transtorno de personalidade borderline and psicanálise and } \\
\text { adicção }\end{array}$ & 0 \\
\hline $\begin{array}{l}\text { transtorno de personalidade borderline and psicanálise and } \\
\text { adição }\end{array}$ & 0 \\
\hline \begin{tabular}{l} 
transtorno de personalidade borderline and dependência \\
\hline
\end{tabular} & 11 \\
\hline
\end{tabular}

O levantamento por publicações com outras terminologias no Portal de Periódicos da Capes se deu inicialmente com a palavra-chave "transtorno de personalidade borderline", que forneceu 25 resultados. Dentre esses trabalhos, seis têm relação com a presente pesquisa - os dois inéditos serão apresentados na Tabela 37. Os demais fazem parte de outros campos ou temas, como literatura, psicofarmacologia, análise do comportamento, transtorno bipolar e suicídio abordado por viés psiquiátrico. Entre os artigos já encontrados e apresentados constam Nunes Costa et al. (2009), Eizirik e Fonagy 
(2009), Silva, Yazigi e Fiore (2008) e Dal'Pizol et al. (2003), respectivamente nas Tabelas $15,5,4$ e 15 .

Com os termos "transtorno de personalidade limítrofe", "transtorno de personalidade emocionalmente instável", "transtorno de personalidade borderline and psicanálise" e "transtorno de personalidade borderline and dependência", foram encontrados trabalhos com temas pouco relevantes para esta pesquisa, tais como psicofarmacologia, autismo, esquizofrenia e transtornos alimentares abordados sob olhar psiquiátrico. As palavras-chave "transtorno de personalidade borderline and psicanálise and adição" não geraram resultados.

Tabela 37. Tema e metodologia dos artigos do Portal de Periódicos da Capes sobre "transtorno de personalidade borderline"

\begin{tabular}{lllll}
\hline Referência & Título & Método & Registro & Análise \\
\hline $\begin{array}{l}\text { Costa, M.; } \\
\text { Mota, C. P.; }\end{array}$ & $\begin{array}{l}\text { Abordagem psicodinâmica } \\
\text { em um estudo de caso sobre } \\
\text { Milheiro, C. } \\
\text { (2013) }\end{array}$ & $\begin{array}{l}\text { Estudo de } \\
\text { caso } \\
\text { transtorno de personalidade }\end{array}$ & $\begin{array}{l}\text { Não espe- } \\
\text { cificado }\end{array}$ & $\begin{array}{l}\text { Não espe- } \\
\text { cificada }\end{array}$ \\
Leblanc, J. et & $\begin{array}{l}\text { Attachement insecure/ } \\
\text { al (2011) }\end{array}$ & $\begin{array}{l}\text { Estudo } \\
\text { clínico } \\
\text { personganise et trouble de } \\
\text { sortir de l'impasse therapeu- } \\
\text { tique? }\end{array}$ & $\begin{array}{l}\text { Não espe- } \\
\text { cificado }\end{array}$ & $\begin{array}{l}\text { Psicanalí- } \\
\text { tica }\end{array}$ \\
& & & & \\
& & & & \\
\hline
\end{tabular}

O artigo de Costa, Mota e Milheiro (2013) aborda o caso clínico de uma jovem em que é evidente a agitação interna e a passagem ao ato sob forma de automutilação. Oferece boa discussão e referências bibliográficas.

Leblanc et al. (2011), por sua vez, discutem o trabalho terapêutico com pacientes fronteiriços, que apresentam dificuldades especiais na relação terapêutica. $\mathrm{O}$ artigo expõe o caso de um paciente e descreve o impasse terapêutico causado pela exacerbação de um apego inseguro / desorganizado. Os autores discutem estratégias de resolução relacionadas com a teoria do apego e fornecem uma compreensão das questões de transferência e contratransferência. O trabalho oferece boas referências bibliográficas e rica discussão sobre o caso clínico. 


\subsection{SÍNTESE SOBRE A REVISÃO BIBLIOGRÁFICA DOS TEMAS "ADICÇÃO" E "FRONTEIRIÇO"}

O panorama obtido com o levantamento nas bases de dados acessadas contribuiu para o reconhecimento da produção sobre o tema do fronteiriço e das adicções, principalmente no que diz respeito às linhas e referências teóricas que orientam essas produções. Como se vê, poucas pesquisas relacionam os estados fronteiriços e as adicções, menos ainda sob a perspectiva psicanalítica, no que se refere à adicção a uma pessoa, fato que aponta para a importância do presente estudo.

Além de trabalhos relevantes, a elaboração da revisão bibliográfica indicou significativa diferença entre publicações disponíveis em bases de dados e trabalhos psicanalíticos publicados em livros. Nas bases de dados consultadas, poucos estudos abordaram diretamente a relação entre adicção e o paciente borderline.

Uma das hipóteses para tal discrepância é a diminuição de pesquisas voltadas estritamente para a psicopatologia, em detrimento de investigações sobre tratamentos, modelos psicoterapêuticos e avaliação de intervenções. De qualquer modo, verificou-se importante acréscimo de publicações entre as buscas de 2014 e 2016, embora o estilo e a direção das produções não apresente muitas diferenças.

A revisão mostra predominância de trabalhos que visam à validação de alguma proposta de investigação ou intervenção, de modo que discussões fundadas em psicopatologia psicanalítica têm menor presença. Foram encontrados muitos estudos relacionados à pesquisa psiquiátrica, além de trabalhos menos expressivos, devido à distância do campo de estudo e ao objeto de investigação. Dentro do campo da saúde mental, temas como a abordagem comportamental e suas derivações, terapias cognitivas, epidemiologia, psicofarmacologia, psicometria e neuropsicologia têm maior presença.

Por outro lado, discussões sobre o tema constituem uma linha importante da produção em psicopatologia psicanalítica contemporânea (CRUZ, 2102; KALLAS, 2012; AUDIBERT, 2008; CHABERT; VERDON, 2008; FREIRE, 2006; LEPOULICHET, 2005; CHAUVET, 2004; BRUSSET, 2004; MCDOUGALL, 2004; MIEL, 2002; SZTUMAN, 1999; BOLLAS, 1994; BERGERET, 1991; GREEN, 1982). Diversos autores se debruçam sobre a relação aqui estudada e esses trabalhos não estão necessariamente disponíveis em bases de dados. Fica clara, portanto, a diferença e a 
distância da cultura de produção de conhecimentos em psicanálise dentro e fora do âmbito acadêmico.

Mesmo que em menor volume em relação a outras abordagens sobre o tema dessa pesquisa, foram obtidas diversas produções que contribuem diretamente ou indiretamente para a realização do trabalho de doutorado, pois constituem fontes ricas e fecundas para o desenvolvimento da tese.

Tabela 38. Refinamento dos resultados e considerações sobre a revisão bibliográfica

\begin{tabular}{|c|c|c|c|c|}
\hline Referência & Título & Fonte & Base de dados & País \\
\hline $\begin{array}{l}\text { Londoño } \\
\text { Paredes, D. } \\
\text { E. (2015) }\end{array}$ & $\begin{array}{l}\text { Elucidación epistémi- } \\
\text { ca e histórica del tras- } \\
\text { torno de la personali- } \\
\text { dad límite o borderline }\end{array}$ & $\begin{array}{l}\text { Revista Co- } \\
\text { lombiana de } \\
\text { Psiquiatría }\end{array}$ & $\begin{array}{l}\text { Portal de } \\
\text { Periódicos } \\
\text { da Capes }\end{array}$ & $\begin{array}{l}\text { Colôm- } \\
\text { bia }\end{array}$ \\
\hline $\begin{array}{l}\text { Hoffmann, } \\
\text { C.; Costa, } \\
\text { R. A. (2014) }\end{array}$ & $\begin{array}{l}\text { Alguns casos, nem } \\
\text { neuróticos, nem aber- } \\
\text { tamente psicóticos }\end{array}$ & Revista Ágora & Scielo & Brasil \\
\hline $\begin{array}{l}\text { Humberg, } \\
\text { L. V. (2014) }\end{array}$ & $\begin{array}{l}\text { Relacionamentos } \\
\text { Adictivos, um estudo } \\
\text { psicanalítico }\end{array}$ & $\begin{array}{l}\text { Biblioteca Di- } \\
\text { gital de Teses } \\
\text { e Dissertações } \\
\text { da USP }\end{array}$ & $\begin{array}{l}\text { Biblioteca Di- } \\
\text { gital de Teses } \\
\text { e Dissertações } \\
\text { da USP }\end{array}$ & Brasil \\
\hline $\begin{array}{l}\text { Lauru, D. } \\
\text { (2014) }\end{array}$ & $\begin{array}{l}\text { Etat limite, adolescen- } \\
\text { ce, cannabis et cocaïne }\end{array}$ & Revista Ágora & Scielo & Brasil \\
\hline $\begin{array}{l}\text { Matusow, } \\
\text { H.; Rosen- } \\
\text { blum, A. } \\
\text { (2013) }\end{array}$ & $\begin{array}{l}\text { The most critical unre- } \\
\text { solved issue associated } \\
\text { with psychoanalytic } \\
\text { theories of addiction: } \\
\text { can the talking cure tell } \\
\text { us anything about sub- } \\
\text { stance use and misuse? }\end{array}$ & $\begin{array}{l}\text { Revista } \\
\text { Substance } \\
\text { Use \& Misuse }\end{array}$ & PubMed & $\begin{array}{l}\text { Inglater- } \\
\text { ra }\end{array}$ \\
\hline $\begin{array}{l}\text { Pereira, } \\
\text { D. R. (2013) }\end{array}$ & $\begin{array}{l}\text { Aspectos da compulsão } \\
\text { à repetição na clínica } \\
\text { psicanalítica: resistên- } \\
\text { cias e toxicomania }\end{array}$ & $\begin{array}{l}\text { Biblioteca Di- } \\
\text { gital de Teses } \\
\text { e Dissertações } \\
\text { da USP }\end{array}$ & $\begin{array}{l}\text { Biblioteca Di- } \\
\text { gital de Teses } \\
\text { e Dissertações } \\
\text { da USP }\end{array}$ & Brasil \\
\hline $\begin{array}{l}\text { Portela de } \\
\text { Carvalho, } \\
\text { M. T.; De } \\
\text { Camargo } \\
\text { Viana, T. } \\
(2013)\end{array}$ & $\begin{array}{l}\text { Trauma and the nega- } \\
\text { tive narcissism in bor- } \\
\text { derline cases }\end{array}$ & $\begin{array}{l}\text { Psychologia. } \\
\text { Avances de la } \\
\text { Disciplina }\end{array}$ & Scielo & $\begin{array}{l}\text { Colôm- } \\
\text { bia }\end{array}$ \\
\hline
\end{tabular}




\begin{tabular}{|c|c|c|c|c|}
\hline $\begin{array}{l}\text { Cruz, } \\
\text { M. (2012) }\end{array}$ & $\begin{array}{l}\text { Reflexões sobre a re- } \\
\text { lação entre a persona- } \\
\text { lidade bordeline e as } \\
\text { adicções. }\end{array}$ & $\begin{array}{l}\text { Biblioteca Di- } \\
\text { gital de Teses } \\
\text { e Dissertações } \\
\text { da USP }\end{array}$ & $\begin{array}{l}\text { Biblioteca Di- } \\
\text { gital de Teses } \\
\text { e Dissertações } \\
\text { da USP }\end{array}$ & Brasil \\
\hline $\begin{array}{l}\text { Daló, L. H. } \\
\text { O. (2012) }\end{array}$ & $\begin{array}{l}\text { A escrita dos estados- } \\
\text { limite como um recur- } \\
\text { so de ampliação da } \\
\text { escuta psicanalítica. }\end{array}$ & $\begin{array}{l}\text { Biblioteca Di- } \\
\text { gital de Teses } \\
\text { e Dissertações } \\
\text { da USP }\end{array}$ & $\begin{array}{l}\text { Biblioteca Di- } \\
\text { gital de Teses } \\
\text { e Dissertações } \\
\text { da USP }\end{array}$ & Brasil \\
\hline $\begin{array}{l}\text { Kallas, R. } \\
\text { G. M. (2012) }\end{array}$ & $\begin{array}{l}\text { Adicção a drogas e } \\
\text { funcionamentos limi- } \\
\text { tes: Suas expressões e } \\
\text { convergências no } \\
\text { Rorschach. }\end{array}$ & $\begin{array}{l}\text { Biblioteca Di- } \\
\text { gital de Teses } \\
\text { e Dissertações } \\
\text { da USP }\end{array}$ & $\begin{array}{l}\text { Biblioteca Di- } \\
\text { gital de Teses } \\
\text { e Dissertações } \\
\text { da USP }\end{array}$ & Brasil \\
\hline $\begin{array}{l}\text { Kemp, R. } \\
\text { (2011) }\end{array}$ & $\begin{array}{l}\text { The symbolic constitu- } \\
\text { tion of addiction: lan- } \\
\text { guage, alienation, am- } \\
\text { bivalence. }\end{array}$ & $\begin{array}{l}\text { Health: An } \\
\text { Interdiscipli- } \\
\text { nary Journal } \\
\text { for the Social } \\
\text { Study of } \\
\text { Health, Illness } \\
\text { and Medicine }\end{array}$ & PubMed & $\begin{array}{l}\text { Inglater- } \\
\text { ra }\end{array}$ \\
\hline $\begin{array}{l}\text { Leblanc, J. } \\
\text { et al. (2011) }\end{array}$ & $\begin{array}{l}\text { Attachement insecure/ } \\
\text { desorganise et trouble } \\
\text { de personnalite limite: } \\
\text { peut-on sortir de l'im- } \\
\text { passe therapeutique? }\end{array}$ & $\begin{array}{l}\text { Revue Santé } \\
\text { Mentale au } \\
\text { Québec }\end{array}$ & $\begin{array}{l}\text { Portal de Pe- } \\
\text { riódicos da } \\
\text { Capes }\end{array}$ & Canadá \\
\hline $\begin{array}{l}\text { García Ló- } \\
\text { pez, M. T. et } \\
\text { al. (2010) }\end{array}$ & $\begin{array}{l}\text { Tratamiento integral } \\
\text { del Trastorno Límite } \\
\text { de Personalidad psica- } \\
\text { nalítica }\end{array}$ & $\begin{array}{l}\text { Revista de La } \\
\text { Asociación Es- } \\
\text { pañola de Neu- } \\
\text { ropsiquiatría }\end{array}$ & Scielo & Espanha \\
\hline $\begin{array}{l}\text { Jordão, A. } \\
\text { B.; Ramires, } \\
\text { V. R. R. } \\
\text { (2010) }\end{array}$ & $\begin{array}{l}\text { Adolescência e orga- } \\
\text { nização de personali- } \\
\text { dade borderline: ca- } \\
\text { racterização dos víncu- } \\
\text { los afetivos }\end{array}$ & $\begin{array}{l}\text { Psicologia: } \\
\text { Teoria e Pes- } \\
\text { quisa }\end{array}$ & Scielo & Brasil \\
\hline $\begin{array}{l}\text { Junqueira, } \\
\text { C. }(2010)\end{array}$ & $\begin{array}{l}\text { Rumo à "metapsicolo- } \\
\text { gia dos limites": O diá- } \\
\text { logo possível entre a } \\
\text { teoria pulsional e a teo- } \\
\text { ria das relações de obje- } \\
\text { to e algumas de suas } \\
\text { consequências - Freud, } \\
\text { Winnicott e Green }\end{array}$ & $\begin{array}{l}\text { Biblioteca Di- } \\
\text { gital de Teses } \\
\text { e Dissertações } \\
\text { da USP }\end{array}$ & $\begin{array}{l}\text { Biblioteca Di- } \\
\text { gital de Teses } \\
\text { e Dissertações } \\
\text { da USP }\end{array}$ & Brasil \\
\hline
\end{tabular}




\begin{tabular}{|c|c|c|c|c|}
\hline $\begin{array}{l}\text { Chagnon, } \\
\text { J. Y. (2009) }\end{array}$ & $\begin{array}{l}\text { Estados-limite nos } \\
\text { trabalhos psicanalíti- } \\
\text { cos franceses }\end{array}$ & $\begin{array}{l}\text { Revista Psico- } \\
\text { logia USP }\end{array}$ & Scielo & Brasil \\
\hline $\begin{array}{l}\text { De Rick, A.; } \\
\text { Vanheule, } \\
\text { S.; Verhae- } \\
\text { ghe, P. } \\
\text { (2009) }\end{array}$ & $\begin{array}{l}\text { Alcohol addiction and } \\
\text { the attachment system: } \\
\text { an empirical study of } \\
\text { attachment style, } \\
\text { alexithymia, and psy- } \\
\text { chiatric disorders in } \\
\text { alcoholic inpatients. }\end{array}$ & $\begin{array}{l}\text { Revista } \\
\text { Substance } \\
\text { Use \& Misuse }\end{array}$ & PubMed & $\begin{array}{l}\text { Inglater- } \\
\text { ra }\end{array}$ \\
\hline $\begin{array}{l}\text { Salomone, } \\
\text { V. P. D. } \\
\text { (2009) }\end{array}$ & $\begin{array}{l}\text { Contribuições de D. } \\
\text { W. Winnicott para o } \\
\text { estudo do distúrbio } \\
\text { borderline e suas im- } \\
\text { plicações clínicas }\end{array}$ & $\begin{array}{l}\text { Biblioteca Di- } \\
\text { gital de Teses } \\
\text { e Dissertações } \\
\text { da PUC-SP }\end{array}$ & $\begin{array}{l}\text { Portal de } \\
\text { Periódicos } \\
\text { da Capes }\end{array}$ & Brasil \\
\hline $\begin{array}{l}\text { Silva, J. F. } \\
\text { R.; Yazigi, } \\
\text { L.; Fiore, M. } \\
\text { L. M. (2008) }\end{array}$ & $\begin{array}{l}\text { Psicanálise e universi- } \\
\text { dade: a interface pos- } \\
\text { sível por meio da pes- } \\
\text { quisa psicanalítica } \\
\text { clínica. Alice quebra- } \\
\text { vidros }\end{array}$ & $\begin{array}{l}\text { Revista } \\
\text { Brasileira de } \\
\text { Psiquiatria }\end{array}$ & Scielo & Brasil \\
\hline $\begin{array}{l}\text { Cardoso, M. } \\
\text { R. (2007) }\end{array}$ & $\begin{array}{l}\text { A impossível "perda" } \\
\text { do outro nos estados } \\
\text { limites: Explorando as } \\
\text { noções de limite e alte- } \\
\text { ridade }\end{array}$ & $\begin{array}{l}\text { Psicologia em } \\
\text { Revista }\end{array}$ & Scielo & Brasil \\
\hline $\begin{array}{l}\text { Kallas, R. G. } \\
\text { M. (2007) }\end{array}$ & $\begin{array}{l}\text { Do psicodiagnóstico à } \\
\text { intervenção em adic- } \\
\text { tos: contribuições do } \\
\text { Rorschach e do aten- } \\
\text { dimento clínico }\end{array}$ & $\begin{array}{l}\text { Biblioteca Di- } \\
\text { gital de Teses } \\
\text { e Dissertações } \\
\text { da USP }\end{array}$ & $\begin{array}{l}\text { Biblioteca Di- } \\
\text { gital de Teses } \\
\text { e Dissertações } \\
\text { da USP }\end{array}$ & Brasil \\
\hline $\begin{array}{l}\text { Figueiredo, } \\
\text { L. C. M. } \\
(2006)\end{array}$ & $\begin{array}{l}\text { Sense of reality, reality } \\
\text { testing and reality pro- } \\
\text { cessing in borderline } \\
\text { patients. }\end{array}$ & $\begin{array}{l}\text { The Interna- } \\
\text { tional Journal } \\
\text { of Psycho- } \\
\text { analysis }\end{array}$ & $\begin{array}{l}\text { Portal de } \\
\text { Periódicos } \\
\text { da Capes }\end{array}$ & $\begin{array}{l}\text { Inglater- } \\
\text { ra }\end{array}$ \\
\hline $\begin{array}{l}\text { Lunbeck, E. } \\
(2006)\end{array}$ & $\begin{array}{l}\text { Borderline histories: } \\
\text { Psychoanalysis inside } \\
\text { and out }\end{array}$ & $\begin{array}{l}\text { Revista } \\
\text { Science in } \\
\text { Context }\end{array}$ & PubMed & $\begin{array}{l}\text { Inglater- } \\
\text { ra }\end{array}$ \\
\hline $\begin{array}{l}\text { Junqueira, } \\
\text { C.; Coelho } \\
\text { Junior, N. } \\
\text { (2006) }\end{array}$ & $\begin{array}{l}\text { Freud e as neuroses atu- } \\
\text { ais: As primeiras obser- } \\
\text { vações psicanalíticas dos } \\
\text { quadros borderline? }\end{array}$ & $\begin{array}{l}\text { Revista } \\
\text { Psicologia } \\
\text { Clínica }\end{array}$ & Scielo & Brasil \\
\hline
\end{tabular}




\begin{tabular}{|c|c|c|c|c|}
\hline $\begin{array}{l}\text { Bradley, R.; } \\
\text { Westen, D. } \\
(2005)\end{array}$ & $\begin{array}{l}\text { The psychodynamics } \\
\text { of borderline personal- } \\
\text { ity disorder: A view } \\
\text { from developmental } \\
\text { psychopathology }\end{array}$ & $\begin{array}{l}\text { Development } \\
\text { and Psycho- } \\
\text { pathology - } \\
\text { Cambridge } \\
\text { Journals } \\
\text { Online }\end{array}$ & $\begin{array}{l}\text { Portal de } \\
\text { Periódicos } \\
\text { da Capes }\end{array}$ & $\begin{array}{l}\text { Inglater- } \\
\text { ra }\end{array}$ \\
\hline $\begin{array}{l}\text { Moreno, M. } \\
\text { M. A. (2004) }\end{array}$ & $\begin{array}{l}\text { Trauma precoce e li- } \\
\text { gações psíquicas, um } \\
\text { estudo psicanalítico }\end{array}$ & $\begin{array}{l}\text { Biblioteca Di- } \\
\text { gital de Teses } \\
\text { e Dissertações } \\
\text { da USP }\end{array}$ & $\begin{array}{l}\text { Biblioteca Di- } \\
\text { gital de Teses } \\
\text { e Dissertações } \\
\text { da USP }\end{array}$ & Brasil \\
\hline $\begin{array}{l}\text { Humberg, } \\
\text { L. V. (2003) }\end{array}$ & $\begin{array}{l}\text { Dependência do víncu- } \\
\text { lo: uma releitura do } \\
\text { conceito de co- } \\
\text { dependência }\end{array}$ & $\begin{array}{l}\text { Biblioteca Di- } \\
\text { gital de Teses } \\
\text { e Dissertações } \\
\text { da USP }\end{array}$ & $\begin{array}{l}\text { Biblioteca Di- } \\
\text { gital de Teses } \\
\text { e Dissertações } \\
\text { da USP }\end{array}$ & Brasil \\
\hline
\end{tabular}

Na tabela acima consta a seleção dos trabalhos mais significativos e diretamente ligados a esta pesquisa, de acordo com a proximidade dos objetos de estudo e das referências teórico-epistemológicas. Assim, torna-se possível visualizar um panorama dos estudos próximos a este, com informações sobre seu país de procedência, os veículos em que foram publicados e a base de dados em que estão acessíveis. Nota-se que diversas publicações brasileiras compõem produções ligadas à proposta deste estudo. Também se destacam artigos de países sul-americanos e europeus, de origem latina, bem como a Inglaterra, locais em que a psicanálise tradicionalmente se estabeleceu na cultura e na produção científica.

Desse modo, a compilação acima não apenas evidencia a relevância do objeto em questão, como corrobora a inserção deste trabalho em um campo e em uma comunidade que realiza investigações contemporâneas de temas estreitamente relacionados. 
Capítulo III

Justificativa e Objetivo 


\subsection{JUSTIFICATIVA}

Tanto as adicções como o tema do fronteiriço constituem desafios clínicos e teóricos importantes na atualidade. São condições que têm exigido de profissionais da saúde mental o fomento e o fortalecimento de bases teóricas, clínicas e éticas para a compreensão e intervenção nesse campo. Um aspecto importante a ser destacado é que, na revisão bibliográfica preliminar, não foi encontrado nenhum trabalho exatamente com o mesmo objeto da presente pesquisa, e até mesmo as investigações sobre temas e objetos afins são escassas. Essa constatação denota a relevância de produções que se debrucem sobre a adicção nos pacientes fronteiriços, foco desta pesquisa.

Do ponto de vista científico, um aspecto relevante a ser considerado consiste na contribuição à delimitação conceitual dos quadros ora abordados, assim como no fomento da discussão psicopatológica das relações entre eles. Além disso, a inclusão, no contexto acadêmico, de discussões fundadas no campo clínico permite o reconhecimento e a ampliação de produções que encontram eco nos aspectos abordados por este estudo. Além disso, essa modalidade de pesquisa científica aplicada a fenômenos clínicos proeminentes alimenta e é alimentada por uma comunidade ocupada com investigação e busca de respostas justas a condições de sofrimento complexas. Dessa forma, este estudo segue na direção de uma ampliação da compreensão do drama contido no sofrimento desses pacientes, iniciada com a investigação de mestrado do autor (CRUZ, 2012).

\subsection{OBJETIVO}

A partir das justificativas acima explicitadas, esta pesquisa visou, principalmente, compreender e descrever a qualidade das relações que os pacientes fronteiriços estabelecem, bem como refletir acerca de distintos aspectos estruturais e da história de vida desses pacientes, a partir de casos clínicos. O estudo buscou ainda apresentar dados de revisão da literatura sobre os temas "fronteiriço" e "adicção", como contribuição a esse campo do conhecimento, no qual se insere a presente pesquisa. 
Capítulo IV

Método 


\subsection{O MÉTODO PSICANALÍTICO}

Este capítulo é dedicado à fundamentação dos caminhos para a realização desta pesquisa, que tem no método psicanalítico opção privilegiada. Criado por Freud (1900/ 1996), esse método caracteriza-se como estratégia investigativa que busca compreender os possíveis sentidos presentes em uma manifestação humana. É hermenêutico em sua essência e parte dessa referência epistemológica por considerar que toda manifestação humana é dotada de sentido, sendo, portanto, passível de compreensão e interpretação.

A palavra "hermenêutica" tem, em sua etimologia, o significado de algo que é levado à compreensão, ou seja, algo que necessita de uma ação interpretativa do homem frente à "sentença dos deuses" (EAGLETON, 2005) para ser compreendido. O termo passou a ser usado como método científico diante da necessidade de diferenciar as ciências da natureza - pautadas pela descrição e pela explicação fenomenológica -, das ciências do espírito - que se debruçam sobre a atribuição de sentido. A posição de busca de sentidos coloca o homem em uma postura ativa frente ao enigma, que pode ser compreendido como pertencente ao campo humano.

A hermenêutica, a partir do ponto de vista apresentado, consiste em forma essencial de abordagem do objeto psicanalítico - no caso, um fenômeno clínico, a adicção ao outro em pacientes fronteiriços. Essa referência de compreensão da construção dos saberes também será utilizada para orientar a interpretação de textos de temática psicanalítica, utilizados na compreensão do fenômeno (EAGLETON, 2005).

Freud (1923/1996) enfatiza que a psicanálise pode ser considerada um método de investigação, uma teoria e uma terapêutica, e destaca que o método é o aspecto essencial, que dá origem aos outros dois elementos. Portanto, colocado em marcha, esse método permite que o tratamento se dê, e que conhecimentos sejam construídos com a proposição de teorias. Dessa forma, teoria e clínica consistem em desdobramentos do método, cuja aplicação as retroalimenta e gera um campo.

Segundo Garcia-Roza (1994), o método psicanalítico pode originar diversos tipos de investigação. Um deles consiste em pesquisa sobre psicanálise, que busca conhecer a história das ideias psicanalíticas, tanto no plano histórico-conceitual, das articulações e desenvolvimentos teóricos, como no plano epistemológico (MEZAN, 1994). O outro modelo decorre da clínica, tem como base o setting transferencial e se denomina 
“pesquisa em psicanálise” ou "pesquisa clínica". De acordo com Mezan (1998), esse caminho é defendido por Freud em suas propostas de ensino de psicanálise na universidade e apoia-se na ideia de que o saber psicanalítico foi influenciado por importantes articulações com as demais ciências. Há também o modelo da pesquisa aplicada ou da psicanálise aplicada, que se baseia na articulação da compreensão psicanalítica com a cultura, como o estudo de uma obra de arte ou fenômeno social.

A presente investigação caracteriza-se como pesquisa em psicanálise, com estudo de caso qualitativo, pois partirá de indagações sobre a clínica e discussão de material decorrente de atendimento. Tem o propósito de construir, a partir do campo clínico, compreensões que visam enriquecer o arcabouço teórico e contribuir para o cuidado de pessoas. O problema foi concebido e o material foi colhido a partir do vínculo paradigmático do pesquisador (ALVES-MAZOTTI, 2006; TURATO, 2000; MOURA; NIKOS, 2000) inserido em seu contexto de trabalho clínico, metodologicamente fundamentado por seu percurso como psicanalista.

Neste estudo, compreende-se que o método psicanalítico é uma forma fecunda de consideração do drama humano, por sua abertura de sentidos e pelo arcabouço gerado por teorizações que considerem a dimensão relacional (GRENBERG; MICHELL, 1994) do acontecer inter-humano, disponíveis no campo psicanalítico, por se tratar de clínica transformada em conceitos. O método psicanalítico, portanto, é o meio pelo qual se dão tanto o tratamento psicanalítico, como a produção científica desse campo.

Teoria e clínica são indissociáveis, e a inclusão do material clínico não ocorre apenas em benefício da pesquisa (TARDIVO, 2004), mas também como contribuição à própria clínica, de onde se originou, assim como incremento na formação do clínico. Tardivo (2004, p. 24) ressalta a importância dessa articulação entre teoria e prática, pois "teoria sem prática é estéril e prática sem fundamentação teórica pode ser superficial e até inconsequente".

Aiello-Vaisberg (1999/2004) aponta duas formas de se relacionar, do ponto de vista emocional, com a teoria psicanalítica. Uma é defensiva, por adotar uma postura de reverência e cristalização, e a outra é mais inventiva. A autora considera a teoria como construção viva, coletiva e contextualizada a partir das transformações da vida e do mundo, com potencial de ser recriada. A subjetividade do pesquisador faz parte do 
campo e da construção de conhecimento (BLEGER, 1963), e esse olhar não implica perda de rigor, tampouco significa um subjetivismo desfavorável à produção científica.

A pesquisadora também considera o homem como ser essencialmente social, criativo e criador, que necessita do outro para ingressar em um mundo humano, concebido a partir de relações (WINNICOTT, 1975; BLEGER, 1963), capaz de transformar o ambiente em que vive e ser transformado por ele, em um processo de criar e encontrar o mundo que habita (WINNICOTT, 1971/1975; CRUZ, 2011). Esse olhar, coincidente com a visão de ser humano de Winnicott (1975), Bleger (1963), Tardivo (2004) e Aiello-Vaisberg (2006), inspira o presente estudo.

Tal visão de ser humano se desdobra em uma forma de produzir sentido que é própria do método psicanalítico e que se caracteriza por abertura, construção e participação (LINO DA SILVA, 1993). Aplicado tanto à clínica como à pesquisa, o método se distingue pela interação entre dois movimentos fundamentais, isentos de crítica e de intenção pré-determinada: a associação livre e a atenção flutuante. A primeira se dá pelo convite à associação livre de ideias, imagens, sentidos e gestos, que operam em registro inconsciente, sem orientação ou controle por seleção voluntária do pensamento (LAPLANCHE; PONTALIS, 2001). De caráter complementar, a atenção flutuante consiste no cultivo de um modo particular de escuta, ancorada em atitude fenomenológica de abertura à comunicação emocional. Na prática, as fantasias dos interlocutores articulam-se em interjogo na busca de um consenso inerentemente provisório.

A partir desse olhar, toda a produção humana - qualquer que seja, desde uma obra de arte, um acontecimento social, até um chiste, um sonho ou um delírio - pode ser considerada carregada de sentidos. No campo da psicopatologia, o método psicanalítico, por seu valor hermenêutico e, portanto, interpretativo, estabelece uma ruptura com tradições científicas exclusivas. Isso significa olhar o ser humano e seu sofrimento a partir de um ponto de vista inclusivo, ou seja, a partir da perspectiva de que nenhuma produção ou ato está fora do alcance da compreensão (TARDIVO, 2004; AIELLOVAISBERG, 1999, 2004; BLEGER, 1962; POLITZER, 1928).

Como exemplo, em contraposição à obra freudiana, ao seu legado e principalmente ao seu método interpretativo, pode-se destacar a tradição da psicopatologia de Karl Jaspers. Com a publicação do artigo "A abordagem fenomenológica em psicopatologia", esse autor inaugurou um campo de saber sobre o sofrimento humano que gerou 
desdobramentos importantíssimos para a saúde mental, principalmente a psiquiatria e parte da psicologia, porém marcadamente divergentes da proposição psicanalítica.

Nesse texto, Jaspers (1912/2005) diferencia sintomas objetivos e observáveis, que podem ser mensuráveis quantitativamente, dos subjetivos, que não podem ser observados por meio dos órgãos dos sentidos. Separou, assim, os sintomas que podem ser compreendidos e os que apenas podem ser explicados. Isso significa que condutas que não podem ser apreendidas empaticamente não são compreendidas, mas explicadas objetivamente, fato que marca uma exclusão do sentido de diversas condições de sofrimento. Segundo Aiello-Vaisberg (2004, p. 90-91):

Dizer que toda manifestação humana está dotada de sentido significa dizer que faz parte, inevitavelmente, do acontecer humano. Portanto, a base do método psicanalítico é uma ética que consiste, sucintamente falando, na inclusão da alteridade. Trata-se, pois, de assumir o reconhecimento de todas as condutas dos seres humanos, cruéis, monstruosas, bestiais, sublimes, generosas, bizarras, ou o que mais se quiser acrescentar - são manifestações humanas e devem ser compreendidas como possibilidades do acontecer humano. Deste modo, quando o método é respeitado em sua radicalidade, compromete o profissional no sentido do lúcido repúdio a todo tipo de exclusão, concreta ou simbólica, de indivíduos e grupos.

Essa citação evidencia um posicionamento que marca um ponto de vista não só epistemológico, mas principalmente ético, frente ao conhecimento e ao sofrimento do outro. Tal perspectiva se contrapõe à psiquiatria clássica, referência que retorna com força nos dias atuais, para a qual algumas manifestações são somente biologicamente causadas (BERCHERIE, 1980), não passíveis de compreensão a partir da biografia e do drama do indivíduo (POLITZER, 1928).

Pode-se entender que a psicanálise oferece uma resposta ética à temática da fragilização da referência do outro e da alteridade, não só do ponto de vista clínico, mas também no seu modo peculiar de fazer ciência e produzir conhecimento. Ganham vulto produções filosóficas e psicanalíticas construídas a partir da década de 1950 e 1960 sobre o tema da alteridade. Isso ocorre por conta de um estatuto da época, que fez emergir formas de sofrimento marcadamente decorrentes da fragilização da referência do outro (SAFRA, 2014). 
Foi nesse momento histórico, por exemplo, que surgiram proposições de dentro da psicanálise sobre os pacientes fronteiriços, expressão radical do espírito contemporâneo, através de autores como Deutch (1986), Kohut (1971/1988) e Winnicott (1969), que apresentaram dramas nomeados como personalidades "como se", personalidades narcísicas e borderline, respectivamente. Tal dimensão ética também se faz presente nesta pesquisa, na qual a produção de sentido consiste em uma resposta a uma condição específica de sofrimento. Seguiu-se, portanto, um caminho de investigação comum ao campo psicanalítico, pois os atendimentos foram realizados segundo necessidades clínicas, servindo posteriormente como material de pesquisa.

Segundo Herrmann (1999), o trabalho do psicanalista ocorre quando o método psicanalítico é colocado em ação, seja atendendo em consultório ou instituição, seja investigando fenômenos culturais, sociais ou clínicos. Nessa perspectiva, o presente estudo procura pôr em marcha o trabalho de compreensão, amparado pela tradição psicanalítica, sem pretender extrair sentidos absolutos. Trata-se da hermenêutica entendida como construção dialética de conhecimento, numa relação de intersubjetividade, campo fértil para criar e encontrar o material que será abordado reflexivamente, em diálogo com outros autores. Assim, uma forma significativa de conhecimento, própria do campo psicanalítico, de caráter compreensivo, poderá ser construída (ORANGE, 1995).

Herrmann (2001/2004) destaca "palavras de ordem” que podem ser referências úteis para a pesquisa em psicanálise, pois se constituem como atos a serem levados em consideração no fazer do psicanalista. São elas: "deixar que surja”, "tomar em consideração" e "completar o desenho". "Deixar que surja" consiste na adoção de postura suficientemente aberta para aguardar que o paciente manifeste, a seu tempo, o que necessita, "aguardando que algum broto de sentido comece a surgir" (p. 72). "Tomar em consideração" diz respeito a não perder, não ignorar aquilo que surgiu. A terceira expressão, “completar o desenho", se dá com a possibilidade de tomar, de forma compreensiva, o que foi apresentado pelo paciente no encontro, para complementar a configuração do sentido emergente.

Essas três "palavras de ordem" não dizem respeito apenas ao método psicanalítico presente no tratamento psicoterapêutico, mas principalmente ao método como produção, registro e tratamento do material a ser trabalhado em pesquisa. Portanto, para a realização desta investigação, serão seguidas três etapas, todas ancoradas no método 
psicanalítico, preservando sua vocação compreensiva de abertura e comunicação. São elas: configuração, registro e interpretação do encontro clínico.

A primeira etapa, de configuração do encontro clínico, consistiu no atendimento de pacientes em psicoterapia psicanalítica individual, já encerrada e devidamente consentida. As indagações e inquietações advindas desse contexto geraram a segunda etapa da pesquisa, registrada sob a forma de narrativa transferencial. A terceira etapa será realizada com a interpretação do material produzido no processo com o paciente, através da atenção flutuante e da associação livre com material teórico, proveniente de diversos autores do campo psicanalítico.

A escolha para a presente pesquisa é a apresentação de caso clínico através de narrativas. É importante destacar que há diferentes compreensões sobre a utilização de casos clínicos em pesquisa em psicologia (NEUBERN, 2001; TURATO, 2000). Influenciados pelo modelo positivista que busca a objetividade de resultados, mesmo sob fachada psicanalítica, predominam os estudos de casos gerais ou de diversos casos, em vez de vinhetas clínicas ou de caso único. Na contramão desse modelo positivista e biomédico, a tradição psicanalítica vem utilizando desde Freud o estudo de casos singulares como rico material de pesquisa e produção de conhecimento. Casos narrados por Freud, como Dora, Anna O., o Homem dos Lobos e até o Pequeno Hans, inauguraram uma forma de registrar e pesquisar a clínica, além de construir um campo (FREUD, 1996/1905; 2000/1914; 1996/1909).

Um exemplo inspirador é apresentado por Winnicott (1941) ao estudar uma situação padronizada de atendimento, que foi nomeada de "jogo da espátula". De início, o pediatra e psicanalista utilizou esse jogo como recurso clínico facilitador para compreender o amadurecimento emocional de crianças, empregando-o conforme as necessidades de cada caso. Posteriormente, utilizou seus registros clínicos em investigação científica.

Há centenas de exemplos de utilização de casos clínicos na literatura psicanalítica, campo do saber necessariamente construído e reformulado pela oferta do relato de experiências dos psicanalistas (FÉDIDA, 1991). Progressos e transformações das teorias, com o reconhecimento de impasses e elaboração de conceitos, ilustrados através de vinhetas, são produto de numerosas experiências clínicas (MCDOUGALL, 1997). Mais do que mera descrição do que se passou no encontro entre psicanalista e paciente, o es- 
tudo de caso é a escrita da clínica psicanalítica e sua teorização, é a transformação da experiência clínica em material de pesquisa, tendo na narrativa o meio privilegiado de comunicação.

A narrativa é o gênero que melhor expressa o drama inerente à experiência humana (SAFRA, 2005; POLITZER, 1928), ou seja, os sentidos advindos da biografia e sua coerência com o sofrimento. Nessa perspectiva, as narrativas transferenciais (AIELLO-VAISBERG et al., 2009; GRANATO; AIELLO-VAISBERG, 2004a) constituem-se como metodologia de registro do que foi vivido no processo psicanalítico dos pacientes estudados e que, de outra forma, ficaria inacessível. Esse recurso consiste no registro a posteriori da lembrança do vivido e se dá como opção favorecedora da apresentação e compreensão do drama contido na experiência emocional dos pacientes, no interjogo contratransferencial.

Elaborada em primeira pessoa, tal narrativa se constrói a partir das nuances da relação, e não da temporalidade ou da organização factual de eventos. Além disso, segue regras constitutivas da psicanálise, através das associações livres do pesquisador, relacionadas ao material clínico, e da atenção flutuante. Trata-se de uma forma de registro clínico que preserva a qualidade intersubjetiva do encontro, ao considerar o pesquisador como parte integrante do campo (BLEGER, 1963).

O foco é dado ao campo transferencial, maximamente presente e compreendido como elemento central sustentador da pesquisa psicanalítica, que ocorre necessariamente pela interação humana. O processo de construção narrativa permite que a produção de sentidos aconteça como relação transicional entre a experiência da dupla clínica e a teoria psicanalítica, sem pretensão de se constituir como descoberta do verdadeiro significado dos acontecimentos contidos no material criado/encontrado.

Nessa metodologia, o impacto gerado na subjetividade do psicanalistapesquisador é o eixo da construção de sua investigação. Engajado na fundação de uma experiência que parte do campo psicanalítico e retorna para seu local de origem, como possibilidade de melhor oferta de cuidado clínico a necessidades reais, cria e encontra seu material de pesquisa em suas inquietações, preocupações e busca de sentido.

Portanto, o princípio norteador deste estudo é o impacto contratransferencial, de encontros com sofrimentos humanos em contextos especializados. É através desse campo que a pesquisa em psicanálise se sustenta, pela interação humana como lugar 
primordial do acontecer clínico, campo necessariamente humano, não estabelecido em termos de distanciamento e suposição de observação isenta. Isso significa que a utilização e a escolha do material clínico consistem "na consideração metodológica de que a seleção do que é psicologicamente importante far-se-á pela via de impactos emocionais vividos pelo pesquisador clínico" (AIELLO-VAISBERG, 2007).

Trata-se de caminho metodológico marcado pelas subjetividades envolvidas, tanto do pesquisador como do participante. Segundo Neubern (2001), a subjetividade na produção científica em psicologia e outras áreas ocupa um lugar marginal, distante do seu reconhecimento como campo de produção de conhecimento frente a influências advindas do paradigma positivista dominante. Isso porque a subjetividade costuma ser considerada pela tendência contemporânea como oposta à objetividade, e não como uma posição fundante e integrante da construção do saber nesse campo.

No caso da presente investigação, ao contrário de tendências objetificantes, pesquisador e pacientes compõem um só campo, espaço intersubjetivo, inter-humano ou relacional. Em uma concepção winnicottiana de pesquisa, inspirada pelos fenômenos transicionais e pelo espaço potencial, Kon (1996) propõe o trabalho com os paradoxos "percebido/criado" ou "realidade/ficção", que não pode e não deve ser superado. As articulações teórico-clínicas propostas nesta pesquisa seguirão esse olhar, na interrelação entre a subjetividade e a bagagem do pesquisador, a tradição psicanalítica e suas construções para a compreensão da psicopatologia dos pacientes fronteiriços.

Dessa forma, pretende-se utilizar o método psicanalítico em todas as etapas deste estudo, desde a configuração do campo de pesquisa, até o registro sob a forma de narrativas transferenciais e a posterior articulação teórica de sentidos presentes na manifestação de sofrimento dos pacientes fronteiriços, expressada através do componente adictivo, particularmente adicção ao outro.

Serão apresentadas três narrativas, de processos realizados com diferentes pacientes, seguidas de suas respectivas discussões teórico-clínicas. 


\subsection{PROCEDIMENTO}

O procedimento é analítico, com registro de sessões na forma de narrativas transferenciais, discutidas em interlocução com autores relevantes para o tema. É importante destacar que, com o recurso de narrativas transferenciais como forma de registro, o pesquisador-terapeuta e os participantes constituem um só campo. Por isso, as narrativas foram elaboradas em primeira pessoa, com a finalidade de preservar o impacto vivido (AIELLO-VAISBERG, 2007).

\subsection{PARTICIPANTES}

Os participantes desta pesquisa foram atendidos em psicoterapia psicanalítica individual no Projeto APOIAR, inserido no Laboratório de Saúde Mental e Psicologia Clínica Social do IPUSP. Todos assinaram o Termo de Consentimento Livre e Esclarecido, que autoriza a utilização dos registros do material clínico em pesquisa. Os atendimentos foram finalizados há mais de um ano, e encontram-se arquivados. Alguns dados foram alterados a fim de proteger a identidade dos participantes, preservando o valor clínico da experiência. 
Capítulo V

Casos Clínicos 
5.1 ROSA E SEUS ESPINHOS 


\subsubsection{Relexões sobre o material clínico}

O percurso terapêutico trilhado com Rosa oferece oportunidade para a investigação da qualidade das relações do paciente fronteiriço. Frente à polissemia e à singularidade que cada história carrega, um encontro clínico como esse oferece diversas possibilidades e diversos eixos de discussão. No presente contexto, o olhar será direcionado à compreensão psicopatológica, a fim de enriquecer a discussão psicanalítica sobre o paciente fronteiriço. 
Com o atendimento de Rosa, que para um olhar mais apressado pode expressar um sofrimento de ordem histérica, eu me deparei com uma configuração psíquica para a qual as figuras mais tradicionais da psicopatologia psicanalítica não me ofereciam respostas satisfatórias. Contudo, o reconhecimento de uma condição não neurótica e fronteiriça, nesse caso, requer uma breve circunscrição.

A referência transferencial torna-se uma baliza importante para situar as vivências de Rosa em determinado eixo psicopatológico, o fronteiriço (GREEN, 2000; GREEN, 1988b; KERNBERG, 1995). Nesse sentido, a experiência com ela sempre revelou um movimento na direção inversa da independência. A paciente parecia buscar e restituir um lugar mal constituído e insuficiente em sua história, assim como fazia exigências radicais de reparação ambiental. Esses traços poderiam indicar a configuração do que Bollas (2000) nomeou de histeria maligna, sobretudo pela oposição regressiva em devolver o Self para caminhos que apontassem para a independência. O autor relaciona esses casos às experiências de regressão maligna, próprias da histeria maligna. Rosa, desde as primeiras sessões comunicava seu repúdio à independência e uma busca pela ratificação do seu lugar de bebê e doente que necessitava de cuidados.

Para pacientes com esse quadro, o processo terapêutico é tomado como campo regido por uma promessa de compensação das falhas brutais e das negligências ambientais, contexto de encontro com objeto idealizado e magicamente reparador. Porém, embora a condição de Rosa apresente certa proximidade com essa descrição, uma qualidade de trauma negativo em sua história esmaece a figura dos objetos que falharam e a lança numa busca, mais do que os presentifica com tal matiz monstruosa. Parece que a mãe pouco pôde tocá-la, marcá-la, mesmo através de identificações projetivas ou invasões inscritas como fato presente em sua memória, pois ela aparentava carregar rastros de um não acontecimento, mais do que o excesso de invasão e presença desses objetos iniciais. O encontro com nuances de relação objetal e seu registro se dão pela busca de turbulência e invasão, expedientes bastante empregados pela paciente e que podem ser pensados à luz do conceito de "desejo borderline" (BOLLAS, 2003).

Do ponto de vista da sexualidade, destacada aqui como elemento diferencial para circunscrever sua condição fronteiriça, Rosa não tomava a genitália ou fontes da sexualidade como ameaças e perturbações, aspecto próprio da histeria. Pelo contrário, fazia um uso da sexualidade, porém sua genitália, seu corpo e suas pulsões não eram 
causas de desestruturação, pois ela comunicava estar aquém dessas referências. Traços fundamentais de uma sexualidade histérica não compareciam na vida emocional dessa paciente. Sofrimentos advindos de escolhas objetais, dramas ligados ao desejo e à fantasia, próprios da neurose (CASTELLO BRANCO, 2004; GREEN 2002; BOLLAS, 2000; GREEN, 2000), não diziam respeito a Rosa. A cena era tomada por um drama narcísico, no qual o outro - como alteridade preenchida e permeada pelo desejo - não existia (CARDOSO, 2005, 2007).

$\mathrm{Na}$ histeria, o outro, prenhe de sentidos, compõe uma trama de paixões e impedimentos, carregada de elementos fantasmáticos que medeiam a relação com objetos. Rosa, por outro lado, sempre pareceu lutar por uma integridade mínima, dependente e dedicada à busca de um objeto vital - qualquer que fosse ele -, cuja perda a lançava em estados de ausência desestruturante e de vazio. Essa forma de funcionamento predominava em sua vida emocional, não tanto por ser habitada por objetos dissonantes, próprios da histeria, mas principalmente pela regressão à dependência e à desorientação, por conta de uma identidade vacilante, mais próxima da despersonalização.

Há, portanto, uma diferença fundamental acerca da importância da sexualidade nas neuroses em relação ao drama de vida e morte, ser e não ser, sentir-se vivo e real nos casos fronteiriços. Para pacientes como Rosa, tal ameaça de aniquilamento é dominante e não abre espaço para a angústia de castração, referência que comparece de forma secundária apenas (BOLLAS, 2003; FIGUEIREDO, 2006; GREEN 1990).

Em geral, estados aparentemente sexualizados e relações sexuais fortuitas não indicam um desejo ou experiência permeada por fantasias para a paciente. Constituem mais um teste de realidade (FIGUEIREDO, 2006) e uma busca pela sensação de estar vivo e existente, do que uma relação erótica. O drama de Rosa estava relacionado com dentro e fora, exclusão e inclusão, impermanência e divisões internas incomunicáveis.

A diferenciação entre recalque e dissociação, nesse contexto, torna-se fundamental. As ansiedades não provinham do retorno do recalcado, mas do contato com elementos dissociados, como no caso de sua amnésia da infância, aspecto que promovia sentimentos de desestruturação e desamparo quando emergia, mesmo que vagamente. No caso de Rosa, era a integração de aspectos do Self que parecia ameaçá-la.

Tal amputação egoica que impede o trânsito por aspectos próprios do Self, marcadamente presente nesse caso, impossibilita o aprendizado com experiência. As- 
sim, predominam sentimentos de confusão, impossibilidade de relação, vaguidão e perda de controle como respostas ao risco de perda objetal e à consequente ameaça de desintegração. Tal desorientação de Rosa se manifestava através de dolorosas queixas sobre sua identidade, superficialidade e incompreensão sobre o que era próprio de sua personalidade.

Green (2000) denomina de "arquipélago" esse estado de divisão interna. Como no caso de Rosa, os arquipélagos são compostos por núcleos diferentes, separados e incomunicáveis. Tal incomunicabilidade de partes do Self acarreta experiência de falta de coerência e identidade devido às fragmentações. Para o autor, essas falhas de integração geram um estado de aparente indiferença e desvitalização, como é possível observar em alguns momentos no percurso com Rosa. Além disso, com partes de si divididas, as relações objetais também permanecem separadas, como uma composição que não pudesse gerar uma pessoa integrada.

Para Green (2000), esses estados se expressam, inclusive, na ausência de consciência da presença do outro, contato limitado e dificuldade de formar representações internas dos objetos devido ao processo de desobjetalização (GREEN, 1988c). No caso de Rosa, é possível observar esse mundo interno despovoado ou "em branco", no qual o sonhar, a simbolização e a figurabilidade não compareciam satisfatoriamente. Tal condição deriva de processos de dissociação que geram, ao mesmo tempo, uma busca desesperada e o desligamento da dor relacionada às ausências originais.

Green (2000) nomeia esse estado de "depressão primária", compreendida como contexto no qual todos os mecanismos de defesa consistem em derivações da dissociação. Em casos de perturbação grave, o autor (2000) menciona a divisão como operadora de uma exclusão radical, como a experimentada por Rosa. Considera que o trabalho de divisão é importante para o psiquismo, que não deve ser sobrecarregado pela tensão e necessita de mecanismos para se defender e sobreviver. Nos casos como o de Rosa, porém, em vez de a divisão funcionar como uma delimitação necessária e útil, ela causa uma “amputação no Ego" (GREEN, 1988b, p. 82).

Nesse mundo interno, carente de marcas fundantes minimamente acessíveis, Rosa experimentava a mãe como uma figura fraca, impessoal e ineficaz; e o padrasto como um homem bom e idealizado, apesar de insuficiente. A hipertrofia dessa idealização do bom não a protegia contra a maldade, as falhas profundas e a onipotência do 
outro, padrasto ou mãe. Entretanto, o que lançava Rosa em um desamparo desértico, marcado pelo temor da separação, estava mais ligado ao apagamento do objeto do que a sua presença violenta.

Parecia prevalecer um vazio identificatório na vida emocional dessa paciente e um desatino na produção de presenças pela intensidade e turbulência nessas relações fundantes (BOLLAS, 2003). Tal característica adictiva de relação, presente em Rosa, torna a qualidade subjetiva do objeto vaga, e a ele é imputada, paradoxalmente, a responsabilidade de restituição e sobrevivência. As crises ou colapsos do fronteiriço, compostos por fragmentação do Ego, causam tal relação paradoxal com o objeto, que este, apesar de temido, permanece como objeto primário e, assim, é inevitavelmente buscado em uma relação de dependência (AUDIBERT, 2008; CHAUVET, 2004; FREIRE, 2006; LE POULICHET, 2005; MIEL, 2002; SZTULMAN, 1999).

Em um desenvolvimento menos conturbado, esse processo consiste em acontecimento de natureza especular, que permite revisões progressivas, e que no estadolimite não se dá satisfatoriamente. Dessa forma, qualquer emoção anuncia a presença desse objeto, e o fronteiriço se vê tentado a buscá-lo pela amplificação de um sentimento comum, que ganha intensidade e se torna uma poderosa experiência emocional. Essa característica se aproxima da adicção - no caso de Rosa, relação adictiva (MCDOUGALL, 1992) -, pois a presença do outro se dá mais pela intensidade emocional e sensorial do que pela relação.

Nesse caso, o fronteiriço consegue formar um outro em seu íntimo, mas o toma como objeto primário, por crer inconscientemente que isso possa constituir uma relação de intimidade verdadeira, apesar de extremamente perturbadora. Com essa forma de contato e demanda, própria de Rosa, o outro (não borderline) experimenta a vivência de invasão e provavelmente buscará uma saída evasiva frente a esse contato. Eu observava isso no relato de minha paciente, tanto quando ela narrava seus diversos encontros com homens que ela mal conhecia e que desapareciam sem aparente explicação, como quando ela abordava sua relação com o marido, restringida ao modelo de cuidador funcional, ou quando referia a perda de efềmeras amizades ao longo de sua história.

O expediente da perturbação e de intensidade emocional gerada nos contatos com as figuras da vida de Rosa consistia em um tipo predominante de recurso, inclusive comigo, em muitos momentos do processo. Condições como essa que Bollas (2003) 
nomeou de "desejo borderline" são permeadas por uma turbulência que não consiste meramente em afeto, e esse estado emocional é dotado de uma violenta intensidade mental que transforma o objeto num "redemoinho de pensamento" (BOLLAS, 2003, p. 7), impedindo qualquer contenção. Desse modo, falar ou pensar não revertem em alívio, como poderia acontecer para um paciente neurótico; ocorre justamente o oposto, uma intensificação da dor que provocou a reação inicial.

Segundo o autor, há uma busca por atacar e perturbar a mente ao criar tal turbulência em sua vida psíquica ou impingir esse estado na mente do outro com falas angustiadas e sem fim. Rosa promovia essa forma de perturbação com frequência e nitidamente se aliviava com minha resposta emocional, em muitos momentos, desconcertada. Bollas (2003) apresenta uma consideração acerca dos limites e fronteiras do estadolimite em relação ao outro, ao apontar que o fato de o objeto borderline estar localizado na fronteira entre o externo e o interno indica o lugar desse objeto primário para tais pacientes. Trata-se de um fora que é ao mesmo tempo dentro, mas não é intermediário. Ocorre um fracasso na constituição do "entre", do transicional (WINNICOTT, 1971).

A tendência do fronteiriço em provocar o máximo impacto emocional em suas relações está vinculada à busca, mesmo que por um breve momento, de um estado de fusão, propiciado pela angústia compartilhada. Porém espera-se que a personalidade não borderline rejeite essa relação. No caso de Rosa, esse movimento rumo à fusão com o outro pode ser visto na insistência dela para ter uma relação sexual comigo, fato que pontuei certa vez dizendo-lhe que com aquele pedido ela buscava grudar em meu corpo. Se para Rosa a turbulência era sinônimo de presença do objeto, sua ausência era também uma representação afetiva desse mesmo objeto primário, como nos casos dos traumas brancos e da mãe morta conceitualizados por Green (1988b). Segundo Bollas (2003, p. 10):

O vazio psíquico é parte da morada do outro no self, uma consequência inevitável do efeito provocador deste objeto sobre o self: cutucado e depois abandonado. Preenchido por uma angústia enfurecida e depois esvaziado. Completude e vazio: estados do self que exprimem o contato com esse objeto.

Segundo Bollas (2003), esse “desejo borderline" se expressa na manutenção do outro dentro de si através da união com parceiros que continuamente os excitam, não por uma via pulsional, mas pelo impacto perturbador no Self. Em Rosa, essa caracte- 
rística se evidenciava por seus encontros pseudo-sexuais, sua relação com parentes, seus apelos atuados, mediados por terror e coerção, buscas enviesadas por uma intensidade contundente de presença. Portanto, ela visava esse preenchimento do vazio, um encontro com uma verdade profunda, através da turbulência e do impacto afetivo, momentos de estranhos contatos com referências fundantes, que remetiam a um objeto familiar que habita o Self. Perturbação e turbulência eram para ela sinônimos de presença, ligação e vida.

A turbulência ocupa, portanto, o lugar do objeto primário, porém o paciente fronteiriço também constitui objetos terciários, criados para existirem fora da ação e da influência do objeto primário. Como as imagens assumidas por Rosa de mulher caricaturalmente sexualizada, pessoa doente e menina mimada a ser cuidada, tais características carregam a tonalidade de um falso Self e, segundo Bollas (2003), são frágeis, geradas com o fim de evitar que o Self seja invadido por estados de opressão muito arriscados para essa organização. É possível considerar então, a partir do percurso de Rosa, que o borderline cria "objetos encobridores" ou protetores que viabilizam a esses pacientes uma condição mínima de atravessar a infância e sobreviver a ela.

Como já foi exposto, pacientes como Rosa são propensos ao desmoronamento emocional. Parecem vulneráveis a acidentes, turbulências e brigas, mesmo que essa busca pelo outro se dê pela reação à sensação de insensibilidade desses objetos. Bollas (2003) indica que o objeto primário opera através desses "acidentes", pois a criança ou bebê experimentou a mãe, ou sua ausência, como um movimento disruptivo. Dessa forma, o objeto de apego é constituído e tingido pela perturbação extrema do outro, como o terror e a raiva que minha paciente gerava.

As intensidades e a turbulência emocional, portanto, constituem um particular objeto de desejo, e esse traço psíquico chama a atenção para uma possível relação com as adicções. Entretanto, o objeto não consistiu em uma substância, algo "inerte" (FUKS, 2000) e desobjetalizado (GREEN, 1988c), mas expressou-se na adicção sexual, na adesão ao marido que "não era ninguém", na extrema dependência em relação ao padrasto e na adicção de transferência (GURFINKEL, 2011). É possível conceber aqui, portanto, uma relação adictiva com um outro humano, conceitualizada por McDougall (1992) como modalidade de vício na qual o objeto não foi tão desumanizado. 
O caso de Rosa expõe um sofrimento cuja esperança de presença do objeto permanece no horizonte. Apesar de apresentar importante difusão da identidade (KERNBERG, 1995), presente nas suas queixas sobre ausência de interesses, superficialidade e estranhamento por não encontrar marcas próprias, a paciente se voltava à busca de um outro capaz de preenchê-la e afastá-la do risco de desmoronamento. Seu apelo regressivo à dependência, expresso no temor de ser uma mulher adulta e no sonho de voltar a ser bebê, denotam a tentativa de manutenção de um paradoxo regressivo (GURFINKEL, 2011; MCDOUGALL, 1992; WINNICOTT, 1975), próprio da relação de objeto adictiva. Retorno ao estado em que o objeto é, ao mesmo tempo, criado e encontrado, capaz de promover a experiência de ilusão e a preparação para a desilusão.

A exigência de manutenção desse paradoxo na vida adulta consiste em patologia grave que fragiliza e torna precária a vida do sujeito. Trata-se do impedimento de um viver criativo, devido à incapacidade de transição do subjetivamente percebido ao objetivamente percebido, consequência fundamental da transicionalidade. Esse é o drama nomeado por McDougall (1992) de "teatro transicional", caracterizado por profunda dependência e incapacidade para o autocuidado. Tal busca de dependência e presença deriva da ausência de um objeto introjetado que torne a pessoa capaz de cuidar de si em momentos de angústia (GURFINKEL, 2011; MCDOUGALL, 1995). Esta é uma condição marcante no processo de Rosa: imputar ao ambiente a responsabilidade de sustentação e provisão de necessidades fundamentais, condição própria de um período de dependência absoluta no início da vida.

A partir da história de vida inicial de Rosa e da precária qualidade da presença materna nesse período, é possível relacionar a busca adictiva da paciente pelo outro aos seus persistentes e esforços de retorno ao período de fusão inicial. Segundo McDougall (1992), essa regressão decorre de uma experiência de contato ameaçadora, quando se torna igualmente insuportável a possibilidade de manter distância do outro e de percebêlo como alteridade. Nesse sentido, conforme Gurfinkel (2011), o bebê tão enunciado por Rosa teme profundamente desenvolver recursos próprios para suportar as tensões. Dessa forma, acaba impedido de desenvolver a capacidade de estar só e procura permanentemente a presença materna e seus substitutos postiços, como recurso para lidar com as experiências afetivas. 
É importante frisar que essas compreensões (GURFINKEL, 2011; MCDOUGALL, 1995), muito próximas do fronteiriço, consistem em olhares advindos da clínica e da teoria sobre a adicção. A partir da experiência de Rosa, portanto, é possível pensar na perda do objeto, própria do fronteiriço, como ignição de uma relação adictiva. Sobretudo, devido a uma ausência objetal fundamental que resulta em estados de incapacidade de autotranquilização e autocuidado na vida adulta.

Dessa forma, Rosa, compreendida como uma paciente fronteiriço-adicta, acaba por recorrer sempre ao mesmo caminho conhecido na infância: buscar no mundo externo o objeto interno ausente. Assim, torna-se evidente a importância da (não) relação de Rosa com a mãe para seu destino aqui narrado. Para McDougall (1995), um objeto substitutivo, no caso pessoas objetificadas nos moldes de uma droga, é descoberto como remédio para mitigar profundas dores emocionais, ao preencher uma função originalmente materna que o sujeito não é capaz de oferecer a si mesmo.

Outro aspecto relevante desse caso é a presença de uma mãe-menina, que ocupa o lugar de irmã-rival ou de filha da filha. A aura blasé da mãe, alheia e desconectada das necessidades da filha, bem como suas demandas invertidas, indicam a importância da qualidade dessa presença para a dinâmica. Segundo McDougall (1995) e Audibert (2008), de certa forma, esses casos também têm origem em condições em que a mãe está em um estado de dependência do bebê, no qual a dependência pode ser compreendida como campo de interdependência ou codependência (GURFINKEL, 2011).

Essa configuração da vida emocional de Rosa deixa clara sua incapacidade de estar só (AUDIBERT, 2008), condição exposta, por exemplo, em suas andanças sexuais adictivas (ESTELLON; MOURAS, 2012), em que estabelecia uma dose controlada de contato e intimidade. Ao mesmo tempo em que a paciente extraía um sinal de sua existência e um impacto capaz de gerar uma presença objetal e frisson transitórios com os encontros, carregava uma tentativa de viver sem o outro, visto que a alteridade era experienciada de forma insuportável. Nesse ponto, a paciente fronteiriço-adicta expõe um paradoxo próprio do fronteiriço e das adicções (BERGERET, 2006, 1998, 1975), o desespero pela dependência e pela presença, concomitante à tentativa de não se tornar refém do outro-ninguém por conta de tamanha necessidade.

De qualquer forma, nesse contexto de súplica pelo outro, acompanhada de evitação da invasão, como na passagem em que implora por sexo, Rosa possivelmente ex- 
pôs esse apelo devido à natureza impeditiva do nosso contato, no qual a comunicação pôde ser reconhecida como necessidade e não como desejo. Tratava-se de mais um pedido de permanência e ligação, sentidos extraídos das vivências contratransferenciais, que mais comoviam do que davam notícias de uma mulher à procura de sexo. Da mesma maneira, quando a paciente pedia para permanecer em meu colo, parecia indicar a necessidade de sustentação, contato e constância. Movimento regressivo que poderia indicar a necessidade de uma presença não ameaçadora, que pudesse sobreviver em sua experiência emocional.

Rosa comunicava, como pano de fundo da turbulência que impingia, esperança de instauração, restituição ou reparação de uma presença (CHABERT; VERDON, 2008; CHABERT, 1999) que a pudesse retirar desse circuito de constante ameaça de perda de objeto e de si mesma. Busca no sentido oposto ao delírio relacional que carregava suas relações e que lhe transmitiam a certeza, independente da resposta do outro, de não sobrevivência do objeto (LEBLANC et al., 2011). No contato terapêutico, sua esperança adictiva, manifestada como uma adicção de transferência (GURFINKEL, 2011), expunha tanto o componente de escravidão e submissão ao objeto, como esperança de transformação (BOLLAS, 2003). Rosa era uma paciente que se comunicava, fazia apelos reiterados, não se cansava.

O que poderia ser compreendido classicamente como efeitos indesejáveis de um processo psicanalítico, próprios do relacionamento adictivo, é justamente o que traz para o campo relacional um tipo de vínculo objetal que tende a um círculo vicioso, sem tempo para acabar. Bollas (2000) reconheceu pacientes que definiu como adictos em transferência, a partir dos quais questionava por que alguns processos terapêuticos se mantêm. Para o autor, existe um desejo secreto de que o processo terapêutico dure para sempre, pela eternização de estados de doença e dor. Rosa, em suas relações não sexualizadas, se posicionava basicamente a partir dessa referência de alguém muito doente e, em análise, apresentou por diversas vezes o temor das consequências de parar de sofrer e não reconhecer outros lugares possíveis nas relações.

Para além de conotações da transferência ligadas à perspectiva de impedimento do espaço para a atividade do pensamento, que também compareciam no processo de Rosa, predominava um fenômeno regressivo tão singelo quanto destrutivo. Eram patentes aspectos de uma regressão maligna (BALINT, 1968/1993) e de uma voracidade to- 
xicomaníaca de transferência, marcadas por necessidades primitivas. O encontro com essa paciente, contudo, apresentava outros matizes além da toxicomania de transferência, descrita por Balint (1968/1993) como uma tendência à substituição compulsiva de anseios e necessidades por outros, na medida em que os primeiros são satisfeitos.

À parte o aspecto estranho e sinistro, próprio da transferência, Rosa lançava um apelo pela construção de uma referência vaga e, talvez, inédita em sua vida, de uma presença minimamente estável e não desestruturante, fora do circuito do controle e da transitoriedade. Perspectiva de trabalho terapêutico que merece ressalvas acerca do aspecto ético e da responsabilidade relacionados à dependência, que com esse cuidado pôde abrir caminho para alguma transformação.

Essa paciente, especificamente, vivenciou a apropriação de aspectos de si em contexto intersubjetivo de reconhecimento, nessa modalidade de encontro especializado que a psicanálise constitui. Pôde viver uma experiência transicional e transformacional, capaz de gerar presença e simbolização mínimas que a afastassem de angústias impensáveis, muito presentes em sua vida. Acontecimentos que abrem espaço para o sonhar e o brincar como posição existencial, perspectiva mais disponível ao fim de um percurso turbulento.

\subsection{TESSITURAS DA ADICÇÃO: DO DESENCANTO AO BRINCAR}




\subsubsection{Reflexões sobre o material clínico}

Paulo chegou ao atendimento em uma condição inicial de desespero, impedido de estabelecer uma relação criativa com o mundo e os objetos. Sua experiência de vazio, impossibilidade de brincar, de ser e de contar com presenças, de imprimir uma transformação e de utilizar de maneira criativa os objetos do mundo são marcas desse processo. Havia, sobretudo, um desatino em busca do outro, lugar ora ocupado por uma substância inerte, ora por figuras mais humanizadas. Esse adolescente vivia uma condição emocional frágil, parecia perdido na busca por preenchimentos internos, presenças que aplacassem um estado desestruturante de solidão. Porém suas tentativas de ser abrigado por grupos e relações eram tingidas de impermeabilidade e distância, de seu ponto de vista. Nesse percurso, as consequências do encontro com objetos-droga indicavam uma coerência biográfica.

Essa narrativa clínica permite questionar posturas que tendem a olhar para o fenômeno da adicção como uma forma estrita de autodestruição. No caso de Paulo, co- 
mo esse material evidencia, a dependência de um objeto inanimado ou do objeto-outro é uma medida desesperada de contenção de estados emocionais ameaçadores e disruptivos, decorrentes da impossibilidade de viver no registro da transicionalidade. A formação de Self fragilizada, própria do fronteiriço, assim como a vaga constituição de objetos mais ou menos impermanentes, leva a desatinos repletos de sofrimento. Esse caso também possibilita compreender tal condição como uma busca predominantemente esperançosa para alguns pacientes fronteiriços, um tipo de automedicação, de restituição de algo que falhou precocemente, mas que pode assumir proporção desenfreada. Tal dependência de elemento externo não chega a completar de fato a ausência do objeto que não pôde se constituir e ser usado. Além disso, revela uma urgência que pode ser compreendida como um colapso da transicionalidade (CRUZ, 2013; CHABERT, 2009; AUDIBERT, 2008; LE POULICHET, 2005; CHAUVET, 2004; MCDOUGALL, 1992). A história de Paulo oferece indícios da impossibilidade de constituição desse espaço intermediário em seu percurso de amadurecimento, condição que o levou a um agir compulsivo e à dependência de elementos exógenos como medida tranquilizadora, orientada por um anseio pela presença do outro. Na medida em que o outro não está disponível para ser usado, esse espaço intermediário não ganha existência consistente e lança o sujeito em um círculo vicioso na esperança de preenchimento.

Com o caso de Paulo, para aquém do registro transicional, é possível entender que havia também uma dimensão pré-transicional em jogo, uma pré-disponibilidade para o que ele buscava. A hipertrofia da droga no horizonte de objetos presentes na vida desse rapaz pode ser compreendida como fruto de uma esperança, como possibilidade de encontrar aquilo a que o sujeito está ansiando, e que busca alcançar com seu movimento. A própria adicção pode ser entendida como uma forma de medicação e tentativa de cura, aquilo que ele sentia que talvez pudesse vir a ser restaurado. Há, portanto, uma pré-concepção, que não é da ordem do simbólico, que move o indivíduo na direção da busca, um tipo de tropismo, elemento que anseia encontrar mas não encontra, no caso da adicção. O brincar pode ser entendido, nesse caso, como fruto da esperança presente nessa busca, de algo que ainda não se constituiu. O desatino em busca de objetos inanimados como a droga e a consequente coisificação do sujeito (GURFINKEL, 1995) representam uma medida defensiva desesperada, já que o outro jamais chega de fato, é quase um "desistir de". Um mundo em desencanto, sem lugar para ritmos, notas, melo- 
dias ou arranjos. Assim, os rompantes de agressividade do rapaz indicavam uma espécie de apelo desesperado por contato e visibilidade. Anunciavam tanto um teste de realidade (FIGUEIREDO, 2003) como um movimento em direção a um outro sem porosidade, contra o qual deveria se lançar com máxima força para alcançar um lugar, e vice-versa.

A busca desesperada pelo outro consiste em elemento central da psicopatologia do fronteiriço. O temor, baseado ou não nas respostas das figuras da vida relacional do indivíduo, comparece como cenário de todas as tramas, reações e aspirações nessa condição psicopatológica. O caso de Paulo destaca que a clínica do fronteiriço e da adicção, como modo de relação objetal, consiste essencialmente no cuidado do desespero, da ameaça de isolamento e do desmoronamento do Self. Trata-se de angústias impensáveis que orbitam a experiência emocional e direcionam o sujeito a reagir com violência no sentido de preservar e reter presenças que, ao cabo, estão fadadas ao desaparecimento, a partir de sua ótica.

A condição de desalojamento e indigência existencial de Paulo comportavam também o aspecto de um olhar e de uma verdade sobre o outro, sua distância e ausência. Diante desse delírio relacional, o rapaz oscilava entre resignação e apelos violentos como reivindicação de presenças que pudessem ser coagidas ou comovidas. Sua história de vida, marcada pela incerteza da sobrevivência da mãe e pela fragilidade da presença paterna ao longo de anos, corrobora a experiência de instabilidade do outro como ponto de vista predominante nas relações posteriores de Paulo. A dor da ausência e da perda rondavam mesmo as relações com certa qualidade e consistência, e orientavam a natureza dos contatos interpessoais. Assim, persistia como condição de vida essa espécie de certeza, um delírio de perda que se construía no presente, mas dizia respeito a um passado não simbolizado (WINNICOTT, 1963).

Dessa forma, Paulo comunicava a dor de não ter um lar em sua própria morada, seu corpo e seu Self, assim como não ter o outro para habitá-lo. Esse paciente relatava sentir-se como um fantasma, um estrangeiro vagando sem rumo. Seu desespero e solidão eram notáveis, contudo permaneceu por muito tempo ao longo do processo sem produzir alguma narrativa sobre si, dava a impressão de um jovem desapossado de história e de um Self disponível como lugar preenchido de objetos. Não havia “Eu”, produções em primeira pessoa em suas enunciações. 
Seu sonho relatado no preâmbulo de uma sessão denota essas referências de ausência e solidão. Sonho emblemático que pode apresentar, de forma figurada, o drama das angústias mais ameaçadoras originadas no início da vida de Paulo. Como destaca Bollas (1992, p. 172), “a invenção de um sonho pode descrever com mais eficiência os temores que a criança tem do mundo, do que o fazem as memórias reais de incidentes assustadores". Trata-se de um tipo específico de memória, não cognitiva, tampouco simbolizada. Consiste em angústia apresentada no sonho pelo trabalho da figurabilidade, que guarda seu valor sobretudo pela comunicação estética de sua atividade onírica.

Paulo praticamente nasceu às voltas com um clima de morte na família, provavelmente comunicado pelo olhar da mãe. Cresceu em contato com essa figura ostensivamente medicada para sobreviver e, em seu percurso de constituição, ele pareceu ter apostado em expediente análogo. O risco de morte e de perda, a presença debilitada da mãe e os períodos de cuidado intermitente da parte dela parecem ter contribuído para uma instabilidade objetal que teve como horizonte de sobrevivência a procura da droga, do outro-droga, como o caso da "Rita, ritalina". Talvez o entorpecimento fosse um trágico destino de reencontro, memória e comunhão com aquela mãe marcada pela sedação e pelo alívio farmacológico da dor. Sua adesão à Ritalina e o encantamento por diversas substâncias entorpecentes denotavam a aposta em um objeto acessível e presente, motivada por seu efeito inebriante. Mas, além disso, evidenciavam uma espécie de outro-postiço-cuidador, como um tipo de prótese materna externa, função análoga a um falso Self não encontrado suficientemente em si mesmo e procurado no mundo exterior.

Paulo parecia almejar também, com o uso de Ritalina, a uma espécie de viagem que o conduzisse a estados alterados, a um novo contato com o mundo quando intoxicado, tranquilizado e acompanhado. Dessa forma, através de seus estados entorpecidos e viajantes, Paulo fazia um uso do psiquismo nos moldes de uma exploração aventureira que saqueia uma área da mente para "localizar delírios" (LAURU, 2014, p.165), como destaca Bollas (1992). Contudo, nesse caso, não se tratava de viagem rumo ao prazer como busca primária, mas da possibilidade de manter sua continuidade como ser e de suportar a aridez subjetiva que comunicava. Nesse sentido, o consumo de uma substância não significava para ele a violação do subjetivo, mas predominantemente a esperança de preservá-lo. 
A transformação repentina promovida por uma droga, que era alvo de grande interesse desse paciente, não consiste em trabalho do Eu. Segundo Bollas (1992), o trabalho egoico torna a vida psíquica possível, assim como possibilita a utilização do material psíquico disponível para reflexão e elaboração. Para o autor, o impacto de uma substância psicoativa usurpa a atividade do Ego de apoio à psique. Esse apoio é o que oferece condição para o abrigo de sonhos, fantasias e objetos no mundo interno e, com a intervenção da droga, tais possibilidades não são promovidas pelo Ego. Nesse sentido, Paulo parecia buscar uma função mal-acabada em seu caminho de constituição, um Eu como setting para os acontecimentos psíquicos e como presença, nesse contexto. Assim, pela ingestão do metilfenidato, mostrava um anseio de recriação de algum elemento essencial de uma situação alimentadora anterior.

Bollas (1992) comenta que, em todos os casos de dependentes de drogas observados por ele, o pai e mãe se apresentavam psiquicamente afastados de seus filhos. Além disso, tais pacientes haviam sido profundamente solitários e isolados na infância. À parte todas as graves consequências dessas condições para a vida emocional do sujeito, Bollas (1992) menciona um ódio secundário, possivelmente presente nos atos de Paulo como agressão, que comporta a esperança e a destrutividade advindas de ausências fulminantes. Para o autor, a destrutividade pode estar vinculada a uma precária sensação de poder, já que o indivíduo consegue derrotar as perspectivas amorosas das figuras próximas. Bollas (1992) menciona a ação da pulsão de morte como componente desses processos. Faz uso do conceito de narcisismo destrutivo de Rosenfeld (1987) para destacar o consumo da substância como meio de promoção de estados de Self inflados, que fazem o indivíduo sentir-se poderoso. Dessa forma, o sujeito se contrapõe a estados e necessidades "de relacionamentos objetais libidinosos" (BOLLAS, 1992, p. 22), ou seja, ao amor, ao cuidado e à interdependência - e, assim, desvaloriza os vínculos de dependência.

Nesse sentido, embora o rapaz não manifestasse ódio em suas falas de forma simbolizada, os estados entorpecidos, assim como seu proto-delírio com a "Rita", talvez guardem paradoxalmente a busca de independência através da presença de uma entidade imaginada. Bollas (1992) indica uma esperança de autoalimentação ambivalente, própria das toxicomanias, referência que pode ajudar a compreender a busca de Paulo. Ao mesmo tempo, trata-se de movimento que constitui uma referência intrinsecamente li- 
gada às suas necessidades mais profundas: a permanência e a disponibilidade de objetos em sua vida emocional. Dessa forma, a luta entre a necessidade de dependência e seu repúdio reativo são condições presentes no adicto e no paciente fronteiriço (CHABERT, 2009; AUDIBERT, 2008; LE POULICHET, 2005; CHAUVET, 2004).

Bollas (1992) aponta uma falha dos objetos primários ao espelhar e elaborar a gestualidade do bebê, assim como suas comunicações, condição impeditiva da experiência de ser compreendido e valorizado através do relacionamento com o objeto. Em vez disso, o bebê irá associar o imaginar com o ir e vir da mãe e do pai, como se ocorresse de acordo com a presença e a ausência deles. A consequência desse tipo de fantasia é a criança projetar sua vida psíquica no objeto externo. Nesse ponto, a vida interna denota uma espécie de container imaginado dos fenômenos psíquicos - e, para Bollas (1992), a presença é associada ao imaginar. No caso de Paulo, seu mundo das drogas e a figura da prostituta que o alimenta são dispositivos imaginativos que visam obturar falhas através desses objetos. Trata-se de expedientes que visam instigar o estado passivo e amortecido através da esperança de transformação. Segundo Bollas (1992), esse estado faz com que o paciente sinta ter encontrado um objeto transformacional capaz de conservar a experiência de ser e dos estados do Self. O drama desse caminho, o apoio inicial de Paulo sobre a substância, é que não se trata de um objeto humano.

Contudo, Paulo sempre manteve apelos mais ou menos efetivos às figuras de seu entorno. Paralelamente ao universo das substâncias, não apenas sofria com a exclusão e o vazio interno, mas também reagia a eles. Trilhou um percurso de relações adictivas (MCDOUGALL, 1992), no contato com a família e os colegas. Trata-se de traço marcante do fronteiriço, figuras tomadas como totalmente boas ou totalmente más, oscilações entre agressão e dependência direcionadas a objetos pouquíssimo percebidos em suas dimensões pessoais. Concomitantemente, Paulo experimentava um medo persecutório relacionado às perspectivas hostis dos objetos. Por exemplo, agredia ao primeiro sinal de indisposição e exclusão do outro, reagia à verdade da rejeição que carregava constantemente.

Nesse ponto, sua busca, ora por fusão, ora por medo de discriminação, indica traços importantes do fronteiriço (KERNBERG, 1991; BERGERET, 1998; GREEN, 1988). Além disso, o paciente apresentava tendência à ação e pobreza na capacidade de simbolização, aspectos também marcantes das relações adictivas (MCDOUGALL, 
1992). Gurfinkel (2011) considera a tendência à ação como uma patologia do afeto relacionada ao desapego paradoxal aos objetos da vida. De fato, Paulo parecia suplicar pelo outro, ao mesmo tempo em que tentava se desprender, nessa dinâmica retroalimentada por tamanha necessidade, insuficiência das respostas e risco de abandono.

Um aspecto muito relevante do processo com esse rapaz consiste na adicção de transferência (GURFINKEL, 2011) desenvolvida durante o atendimento. Sobre essa dimensão fundamental para a presente discussão clínica, o autor destaca a importante inter-relação entre transferência, regressão e dependência. Com o caminhar do processo terapêutico de Paulo, tornou-se evidente um movimento regressivo em direção à dependência do terapeuta, uma regressão relacionada ao desenvolvimento do Eu. Esse paciente apresentava indícios, visíveis em sua biografia, de interrupções do amadurecimento no nível da falha básica (BALINT, 1993/1968) ou da estruturação básica que garante a sobrevivência e a manutenção de um mínimo $\mathrm{Eu}$, uma condição narcísica preservada que propicie a continuidade de ser e a identidade. Ou seja, tais aquisições proporcionadas por um percurso de amadurecimento suficientemente bom, como a estruturação do $\mathrm{Eu}$, dos objetos de realidade e a corporeidade haviam sido atravessados por falhas ambientais precoces e disruptivas.

O apelo maciço à dependência, manifestada por Paulo nos momentos em que se alimentava, habitava a sala de espera ou chegava ensanguentado necessitando de cuidados físicos, assim como os convites para o brincar, denotam anseio regressivo à dependência. Em suas ligações de madrugada, dezenas de recados, expressava busca de contato e de alguém do outro lado da linha. Talvez ansiasse por uma ligação de fato, manifestada por linha e cordão, nos moldes do caso atendido por Winnicott de um menino que desenhou cordões, chicotes, ioiô, nós e laços no Departamento de Psicologia do Hospital Paddington Green em 1955, conhecido como “o menino do cordão" e que desenvolveu adicção às drogas na adolescência. Winnicott $(1975$, p. 36) compreende o cordão "como uma extensão de todas as outras técnicas de comunicação". No caso de utilização excessiva, pode denotar tanto sentimentos de insegurança como de falta de comunicação. Nesse caso, a função do cordão se perverte, modifica-se de "comunicação para negação da separação. Como negação, o cordão se torna uma coisa em si, algo que possui propriedades perigosas e necessidades que precisam ser dominadas". É importante frisar que no início essa utilização do cordão continha esperança, como nos atos exer- 
cidos por Paulo em seus diversos telefonemas. A diferença marcante é que na ligação telefônica há alguém humano do outro lado da linha.

Nesse sentido, a partir das construções de Winnicott (1975) sobre o caso clínico do menino dos cordões, e ao relacioná-lo com o percurso de Paulo, torna-se possível reconhecer um movimento na direção contrária ao amadurecimento emocional, um retorno ao estado próximo ao trauma na busca de um descongelamento de aspectos próprios para que possam ser integrados. É apenas através da experiência de dependência, segundo a perspectiva winnicottiana, que é possível conquistar um nível mínimo de integração para caminhar rumo à independência. Paulo parecia pedir tacitamente por tal dependência. Talvez pela intensidade da coisificação sofrida, tenha mirado seu apelo e sua esperança em objetos inertes; contudo, com o tratamento psicanalítico, pôde deslocar a direção de seus investimentos para um outro com traço humano. Nesse sentido, o olhar para o percurso desse paciente se vincula à perspectiva relacional (GRIMBERG; MITCHEL, 1983), para a qual a concepção de desenvolvimento se funda no reconhecimento de necessidades em detrimento do desejo, a partir da constituição de um Eu no ambiente e não da concepção de libido, a partir do intersubjetivo em vez do intrassubjetivo.

O aspecto de fruição do prazer não eram figuras em primeiro plano na experiência emocional de Paulo, apesar de ser um adolescente (JORDÃO; RAMIRES, 2010). A droga parecia ser a tentativa de recriar um holding não encontrado suficientemente bem em momentos cruciais de sua constituição, sempre promovido necessariamente por um outro sustentador, em uma relação de refinada adaptação. Assim, além da busca pelo objeto e pela sua permanência, a adicção constitui a transformação e a integração do Self, condensados no objeto transformacional droga (BOLLAS, 1994). Entretanto, como perspectiva de transformação para este paciente, a droga impunha seus limites radicalmente e se apresentava como solução transitória, que o lançava em seguida no mesmo estado. Na medida em que a perspectiva regressiva implementa a referência do outro, inclusive para que a droga possa ser dirigida e compartilhada em uma relação, o cenário de busca de humanização e integração ganha horizontes mais amplos. Do mesmo modo, a possibilidade de uma relação adictiva ser vivida no contexto de adicção de transferência permite respostas mais justas às necessidades em jogo, assim como a viabilidade de transformação do Self e a construção de objetos mais estáveis internamente. 
Nesse caso, as perspectivas de adesão à droga e ao outro-droga significam para pacientes fronteiriços como Paulo, segundo Bollas (1994), a repetição de situações precoces, através das quais se lembram existencialmente de suas origens. Paulo dava mostras de guardar um retrato materno em algum lugar do seu Self, ativado por um entorpecimento, protoemoções (FERRO, 1998) à espera de uma perturbação existencial que remetese a experiências transformacionais cumulativas do Self. O paciente parecia buscar uma chave de ignição, com a droga e com o outro-droga, de poderosas metamorfoses do ser, porém pouco encontradas na substância e em suas relações adictivas. Com a música, acessada a partir do contexto intersubjetivo, possivelmente pôde conquistar uma experiência estética como um elemento simbólico equivalente ao objeto transformacional, fora da lógica da adicção e no caminho da conquista do espaço potencial. Bollas (1994) relaciona a experiência transformacional à busca de experiências estéticas, como visita a museus ou contemplação de paisagens. Mediante essas experiências, que se dão nos moldes da fé a uma divindade, presente e ausente ao mesmo tempo, o autor pontua a possibilidade de alteração do ambiente, em elementos passíveis de reflexão por habitarem referência estritamente estética e existencial.

No brincar de Paulo, principalmente com a música, em seus devaneios de superstar, o objeto transformacional permanece situado em algum lugar do futuro, de modo que o paciente fica "ruminando planos sobre o devir" (BOLLAS, 2015/1992, p.53), o que fazer, aonde ir. Para o autor, a localização de um devir estético soa como uma oração psíquica para a chegada do objeto transformacional, como um som, uma nota, em um átimo, vindo de uma relação objetal vivida em períodos precoces da vida. No exemplo clínico que o autor oferece, pacientes jogadores viviam, ao apostar, um momento estético que representava a relação deles com a mãe, bem como a convicção manifestada por eles de que ela não chegaria com suprimentos. Paulo, porém, pôde de algum modo migrar, a partir de um brincar a dois, de um instante de ilusão passageira para um campo mais próximo da transicionalidade.

A partir da experiência com ele é possível compreender o lugar do brincar na clínica das adicções e do fronteiriço - perspectiva muitas vezes buscada e esperada, porém perdida, em circuitos de repetições dolorosas e estados de solidão profundos. Uma música sozinha não existe, depende de alguém para ser tocada e ouvida, se destina sempre a uma audiência em um campo de encontro. 
5.3 ESPERANÇA E IMPOSSIBILIDADE NA CLÍNICA DA ADICÇÃo 


\subsubsection{Reflexões sobre o material clínico}

O sofrimento e as manifestações psicopatológicas apreendidas no percurso terapêutico de Leonardo evidenciam importante relacionamento adictivo, expresso na história dele com a esposa, além da dependência de cocaína. O material clínico oferecido pelo processo desse paciente fronteiriço carrega maior importância para a presente pesquisa na qualidade das manifestações psicopatológicas - dependência ao outro - e no impacto contratransferencial, do que na apreciação do desdobramento ou do manejo do caso.

Torna-se importante destacar que Leonardo apresentava significativa difusão de identidade (KERNBERG, 1991), reconhecida principalmente em episódios de separação e angústia. Trata-se de um paciente que organizou sua vida em torno de uma cultura da droga, porém permaneceu fragilizado em termos de vínculos, estabilidade emocional e dependência do outro. Foi com o auxílio da esposa que ele parece ter encontrado um alívio para angústias impensáveis e para uma instabilidade de Self que irrompiam em momentos de ameaça e separação. Como já foi dito, as duas figuras mais presentes em suas queixas e em sua vida relacional eram a esposa e a cocaína. A extrema dependência em relação a esses objetos evidencia a falência do registro intermediário, da capacidade de trânsito nas relações e da experiência de permanência dos objetos internamente.

O casamento de Leonardo, considerado sob o prisma das relações adictivas, carrega a marca da insatisfação própria dessa condição, além da impossibilidade de separação. De acordo com Humberg (2014), há várias razões para a manutenção dessa natureza de relação, inclusive situações em que a pessoa necessita da condição social e pessoal de estar casada como evidência ou "prótese" que prometa o preenchimento do vazio que sente de alguma forma. Nesse sentido, a perspectiva de não estar casado corresponde ao retorno de uma vivência de vazio total, sem sustentação, angústias de cair para sempre e estar isolado, como as agonias impensáveis a que Winnicott (1963) se refere. Frente a tamanho risco, o sujeito suporta a insatisfação e os males de um relacionamento dessa natureza, no qual, paradoxalmente, se protege de angústias pungentes, sustentando outras formas de sofrimento computadas como menos piores, em comparação ao risco radical do qual se protege. 
Em casamentos como o de Leonardo, nos quais não é possível se separar, do ponto de vista de um dos cônjuges, a união matrimonial é tratada como uma droga, que permite a manutenção de uma integração e de uma identidade, mesmo que esse vínculo conjugal corresponda a uma falência. De acordo com Humberg (2014), essa forma de relação pode consistir em uma maneira de permanecer sozinho, embora casado, e de não brigar com a necessidade adictiva. A autora frisa que alguns casos como esses são maneiras razoáveis de viver, formas não ideais, porém possíveis. Contudo, Humberg destaca que esse tipo de casal costuma acabar se separando, às vezes já em idade avançada, após décadas de união.

Frente a tal qualidade de sofrimento e relacionamento, a violência reativa e a destrutividade de Leonardo alinhavam-se a uma formação psicopatológica fronteiriça, carregada da marca de uma tendência antissocial. Nesse sentido, torna-se importante localizar que ele é compreendido como fronteiriço por evidenciar fundamental angústia de perda de objeto como organizadora de suas relações, uma identidade vacilante, um Self instável, ausência de estrutura enquadrante, impulsividade e reatividade. Dessa forma, faz-se necessária a realização de uma breve circunscrição acerca da tendência antissocial no fronteiriço.

A violência e a destrutividade são marcas comuns ao fronteiriço e à tendência antissocial. É importante frisar a compatibilidade dessas referências psicopatológicas manifestadas por Leonardo, já que, segundo Winnicott (2002/1958), a tendência antissocial não constitui um quadro clínico propriamente e pode se dar em indivíduos neuróticos, psicóticos ou borderlines. Em termos etiológicos, o fronteiriço sofreu invasões ambientais graves entre a fase de dependência absoluta e a relativa. Portanto, trata-se de um início perturbado em um ambiente instável e ambivalente. O efeito sobre a constituição do sujeito recai em um Self mal-acabado, assim como na grave ameaça de perda de objeto. Frente a tal ameaça, perspectivas destrutivas e agressivas surgem como reação à possibilidade de perda e desintegração. Nesse sentido, Leonardo parece ter vivido realmente um início de vida bastante instável desde os primeiros meses. Tanto a qualidade da presença da mãe como as invasões promovidas pelo pai possivelmente compõem o cenário de profunda precariedade da função sustentadora do ambiente.

A tendência antissocial, por sua vez, consiste em uma formação posterior, advinda depois que o período de dependência absoluta é atravessado. Ou seja, apenas no 
período de dependência relativa é que falhas ambientais e privações constituiriam a formação de atos antissociais movidos pelo sujeito no sentido de reaver aquilo de que ele foi espoliado. Nesse sentido, Leonardo apresenta uma desorganização psíquica anterior a esse período, contudo carrega a agressividade e a esperança de vinculações filiadas a perspectivas destrutivas ou fora da lei.

Um ponto de aproximação de uma tendência antissocial circunscrita em uma condição fronteiriça, a partir da história de Leonardo, reside no fenômeno da dissociação. Trata-se de um acontecimento clínico e de um conceito vastamente abordados por Winnicott, em diversos contextos. Resumidamente, para o autor (1982/1945), a dissociação ocorre quando há uma integração incompleta de algum aspecto do Self. Winnicott (1997/1965) ilustra o conceito de dissociação com o caso clínico de um paciente de tendência antissocial que, após cometer um roubo, carrega uma culpa conhecida mas não sentida, ou seja, reconhecida intelectualmente, porém não vivida afetivamente. Eis um recurso de sobrevivência emocional que pode ocasionar diversos níveis de consequência. Em casos graves, empregado maciçamente, promove estados nos quais o indivíduo acaba por não se sentir vivo e real, desde uma espécie de desligamento emocional, até estados de profunda irrealidade e vazio.

O percurso de Leonardo dá indícios de importantes dissociações que atingem a formação de uma identidade estável, mas não o protegem suficientemente do risco de desintegração e das angústias decorrentes da perda do objeto. Ele parecia querer arrancar da esposa algo que não conseguia extrair satisfatoriamente. Como uma forma de apropriação do lhe era de direito, impunha a ela gestos nos moldes de uma extorsão, funções e cuidados que não eram construídos a partir da experiência de troca. Nesse sentido, o paciente parecia pegar para si o que sentia merecer, do seu ponto de vista elementos reivindicados e vitais para sua sustentação emocional. Assim, aspectos da tendência antissocial se aglutinam direcionados ao objeto-outro, sempre carregado da ameaça de perda.

Sobre suas relações adictivas propriamente, a esposa e a cocaína organizaram e aplacaram profundas angústias, tornaram-se meios de sobrevivência emocional. De acordo com McDougall (1992), as adicções e os relacionamentos adictivos têm origem em angústias vividas no início do desenvolvimento emocional, quando o indivíduo ainda não estava predominantemente integrado e por isso era impossível a diferenciação 
entre Eu e não-Eu, bem como o reconhecimento de si e do outro como pessoas autônomas. Da mesma forma, advêm de angústias que orientam o sujeito para a solução adictiva, associada a relacionamentos interpessoais nos quais o indivíduo conquista certa diferenciação, porém não consegue administrar as intensidades pulsionais. Nesse sentido, Leonardo dá indícios de carregar importantes angústias impensáveis, que não decorrem de descaminhos de forças pulsionais. Isso se torna patente em seu histórico de tentativas de suicídio, na automutilação e no episódio psicótico que vivenciou. Dessa forma, é possível pensar nesse paciente como um fronteiriço que carrega traços antissociais, em que a violência opera predominantemente na retenção do outro de forma coercitiva.

De acordo com Humberg (2014), a formação de relacionamentos adictivos, a partir de sua experiência clínica, deriva principalmente de angústias ligadas a experiências que levam o sujeito a um vazio existencial ou à ameaça de aniquilação. Dessa forma, essas condições remetem a angústias impensáveis e também a condições que traduzem falhas na transicionalidade e invasões ambientais que rompem a experiência de continuidade de ser. Tais angústias emergem, portanto, em indivíduos ainda não integrados.

Para a autora, os relacionamentos adictivos também podem consistir de atitudes antissociais, já que o ato antissocial visa restituir a provisão ambiental perdida, seja promovida pelo outro de quem se depende, seja pelo fato de a relação com o outro (ou com alguma droga) constituir uma agressão que carrega um pedido de ajuda direcionado ao ambiente. Nesse sentido, Leonardo dá diversos indícios de construir seus relacionamentos adictivos como meio de sobrevivência e preservação de uma precária estabilidade do Self.

Dessa forma, angústias de aniquilamento provindas de falhas da transicionalidade parecem orientar os destinos da vida emocional de Leonardo, embora sua biografia seja marcada por falhas que também remetem à privação. Suas menções ao brinquedo que nunca veio e ao rap que indica uma arma no lugar de um brinquedo dizem respeito à sonegação por parte do ambiente de algo que deveria ter sido ofertado e não foi. Contudo, as consequências psicopatológicas para Leonardo residem em fragilidades mais profundas do que a busca pela recuperação daquilo que foi retirado precocemente.

Tomando sua experiência, reconhecida como própria do fronteiriço, a partir do prisma relacional ou vincular, é possível reconhecer que o sofrimento se dá como um afastamento de si mesmo através de defesas dissociativas, que podem ocorrer em dife- 
rentes graus. Nesse sentido, segundo Medeiros e Aiello-Vaisberg (2010), é possível tomar como referência uma visão tripartite do sofrimento, nos termos de neurose, psicose e borderline. Nesse último caso incluem-se os fenômenos depressivos, a tendência antissocial e as construções do tipo falso Self. Além dessa visão explícita na obra winnicottiana, as autoras reconhecem um olhar implícito de Winnicott para a psicopatologia, a partir de referência puramente relacional. Dessa forma, é possível reconhecer que Leonardo foi violentado em estágios muito precoces do desenvolvimento, além de ser exposto a condições de instabilidade marcante ao longo dos primeiros anos de vida.

A partir dessas marcas, percebe-se que ele não se constituiu satisfatoriamente, inclusive de seu ponto de vista. Da mesma forma, o outro parece ter surgido como uma espécie de "bote salva-vidas" que ele deveria agarrar, sem a possibilidade de considerar quem estava ali. Assim, tanto a integridade do Self como a do objeto vacilaram ao longo de sua história e o levaram aos arremedos adictivos como perspectiva extrema para aplacar riscos existenciais profundos.

O material clínico de Leonardo apresenta, portanto, elementos significativos que corroboram a compreensão de um estatuto fronteiriço no qual a dependência extrema do objeto se dá como forma de relação objetal preponderante. Elementos como a dependência em relação à esposa, o medo constante de perda e abandono, a reivindicação violenta por cuidados e presença integral, os episódios depressivos ou dissociativos, a inconsistência de sua identidade, o vazio e a desorientação, a pobreza de objetos em seu mundo são expressões de um sofrimento no qual a ameaça de desabamento orbita uma condição com pouquíssimos recursos próprios de sustentação. A adesão a objetos como forma de cura - no caso, a esposa e a droga - e a ausência de outras figuras denotam falência transicional e colapso do sonhar (GURFINKEL, 2001). Leonardo parecia se esforçar para manter-se integrado, não tinha sonhos ou vida, fora o circuito apresentado.

A partir da história desse paciente é possível compreender sua relação com a esposa como uma busca de alívio e afastamento de intensas angústias. Nesse sentido, aferrou-se a ela como uma droga e manteve preservada a ligação com o objeto humano como alvo de seus apelos, embora a cocaína tenha permanecido em sua vida. Contudo, tal experiência de relacionamento não se dava pela via da troca, do reconhecimento ou da nutrição subjetiva. A ela estava reservada a missão de proteção e sobrevivência de um Self precariamente constituído. 
Capítulo VI

Discussão 
Para a realização da presente pesquisa, referências a diversos autores foram evocadas ao longo desta tese, a fim de promover reflexões dentro de um campo extremamente vasto, capaz de gerar uma multiplicidade de digressões. Assim, torna-se importante destacar que a dependência ao outro nos pacientes fronteiriços compareceu de forma periférica nos textos psicanalíticos estudados, porém o aspecto adictivo permeou as entrelinhas sem o destaque proposto neste estudo. Os destinos da angústia de perda de objeto (GREEN, 2000; KERNBERG, 1995, 1991; BERGERET, 1996, 1991; AUDIBERT, 2008; LE POULICHET, 2005; BRUSSET, 2004; CHAUVET, 2004) como referência central na psicopatologia desse quadro, a relação anaclítica (BERGERET, 1996, 1991), o colapso da transicionalidade (MCDOUGALL, 2004, 1992; WINNICOTT, 1975) e a consequente vaguidão do outro na vida emocional do sujeito, bem como o comprometimento da capacidade simbólica (CHABERT, 2009; AUDIBERT, 2008; LE POULICHET, 2005; MORENO, 2004; CHAUVET, 2004; MCDOUGALL, 1992), compõem referências muito próximas de um estado de adicção (MATUSOW; ROSENBLUM, 2013; PEREIRA, 2013), cuja compulsão na direção do objeto-outro, sempre necessário e impermanente, torna-se um meio de vida.

Considerando a forma de relacionamento predominante nos casos abordados, a partir das narrativas transferenciais apresentadas e da bibliografia levantada, torna-se possível estabelecer uma aproximação da condição de adicção e do sofrimento fronteiriço. Em relação às produções próximas ao tema deste trabalho, encontradas nas bases de dados consultadas, muitos artigos trouxeram elementos importantes, como novas referências bibliográficas e caracterizações do fronteiriço. De qualquer maneira, um resultado importante se refere ao fato de os trabalhos publicados em forma de livros abordarem os aspectos relacionais do fronteiriço, em maior número. Os resultados obtidos por meio das bases de dados apresentam um grande número de trabalhos, tanto sobre o fronteiriço como sobre a adicção, porém com vieses bastante diversificados. Entre os trabalhos levantados, destacam-se aqueles que contribuem mais diretamente para a compreensão de um vínculo adictivo presente nos pacientes fronteiriços.

Entre estes estudos está o de Fernández-Montalvo e Lorea (2008), que aponta a importante correlação entre a personalidade bordeline e a dependência de cocaína. $\mathrm{O}$ trabalho de Lauru (2014) aborda a ligação entre o fronteiriço e a busca por cannabis e cocaína como ansiolíticos, defesa contra o medo da loucura, despersonalização e regres- 
sões. Almeida-Prado e Féres-Carneiro (2010) expõem um traço próximo da adicção, ligado à relação entre o borderline e a compulsão alimentar, compreendida como problemática essencialmente narcísica. O artigo de Rosa e Santos (2011) discute a aproximação da bulimia e do paciente borderline, abordando essa relação do ponto de vista da compulsão e do vício. Portela de Carvalho e De Camargo Viana (2013) apontam para o importante traço compulsivo presente nos fronteiriços, relacionado à proteção contra o vazio e à inconstância de objetos. Os trabalhos de Cruz (2012) e Kallas (2012, 2007) tratam diretamente da relação entre a adicção e o paciente fronteiriço. O artigo de Leblanc et al. (2011) destaca as relações do apego inseguro / desorganizado com diferentes destinos, como a adicção.

Os casos de Rosa, Paulo e Leonardo revelam importantes elementos que encontram eco nas produções mencionadas, desde a marca da compulsão, até a busca de automedicação de estados emocionais dolorosos e ameaçadores. Assim, o material compreendido psicanaliticamente neste trabalho oferece a oportunidade de apreensão da qualidade específica da relação objetal constituída como adicção. As dinâmicas de Rosa, Paulo e Leonardo, em seus percursos terapêuticos, tornaram proeminente o impacto da impossibilidade de separação, a ameaça decorrente da perda do outro, assim como a busca e a manutenção do vínculo adictivo carregado de esperança.

Do ponto de vista psicopatológico, os casos expõem sofrimentos derivados de contornos frágeis do Self e da ameaça de colapso pela perda do objeto. Sobressaem igualmente a impossibilidade de estar só, o vazio, a busca desesperada por um objeto externo, a identidade frágil e a hipertrofia da ação (GURFINKEL, 2011, 2008; BERGERET, 1998; GREEN, 1988b). As condições emocionais contidas nas narrativas transferenciais denotam grave prejuízo da simbolização, derivado do colapso da terceira área da experiência humana, conceitualizada por Winnicott (1975). Tal colapso impede a experiência consistente de presença do outro, bem como a possibilidade de compartilhamento e coexistência. Ainda assim, a intersecção fronteiriço-adicto pode ser reconhecida, nos casos estudados neste trabalho, no qual as dinâmicas se confundem.

Dessa forma, a retomada do conceito de fronteiriço e sua aproximação com a adicção tornam-se necessárias, a partir do material construído na forma de narrativa. Os sofrimentos ora abordados carregam as marcas de angústias essencialmente psicóticas em uma organização aparentemente neurótica, conforme o ponto de vista da psicanálise 
winnicottiana (WINNICOTT, 1963, 1963b, 1969). Os três pacientes estudados apresentaram dramas relacionados à proteção da integridade psíquica e emocional, assim como desatinos para impedir a perda do outro e o colapso a que isso remete. Da mesma maneira, o material apresentado permite a identificação de componentes essenciais do fronteiriço, em especial o agir e a dissociação, conforme Green (1988a). Outros elementos característicos do fronteiriço também puderam ser apreendidos através das narrativas transferenciais, tais como problemas de integração da identidade (KERNBERG, 1995, 1991, 1967) e a angústia central de perda objetal (BERGERET, 2006, 1998, 1991, 1986, 1975).

Os três casos aqui estudados permitem reconhecer uma ponte entre o fronteiriço e a adicção, principalmente pela presença de processos compulsivos nos moldes de vício e afastamento do vazio, em consonância com os trabalhos de Portela de Carvalho e De Camargo Viana (2013) e Hoffmann e Costa (2014). A leitura teórico-clínica dos casos de Rosa, Paulo e Leonardo a partir do conceito de adiç̧ão se mostrou produtiva, orientando o eixo compreensivo em torno do drama de perda objetal e da consequente dependência em relação ao objeto-outro como único meio de busca de alívio, nos mesmos moldes da dependência a uma droga (CRUZ; TARDIVO, 2013; CRUZ, 2012). As condições emocionais destacadas nas narrativas expõem estados de escravidão que, apesar dos inegáveis aspectos destrutivos envolvidos, se instala por um movimento originalmente relacionado à busca de alívio e transformação. A adicção como componente da dinâmica dos pacientes permite uma diferenciação de processos defensivos exclusivamente ligados à relação inter-humana, na qual o outro preserva o estatuto de pessoa.

Dessa forma, a partir dos casos apresentados, é possível observar dinâmicas relacionadas à perda do objeto que envolvem a busca de substâncias e de um outro-droga, modos de relacionamento adictivo independentes do objeto em questão. Assim, nesses casos, seres humanos e substâncias parecem portar a mesma condição de objeto buscado para cumprir função de sobrevivência emocional, de modo que traços humanos e pessoais não consistem em referências determinantes de busca e relação. Contudo, dinâmicas muito próximas geram maior ou menor proximidade com o elemento que não foi constituído no percurso de desenvolvimento do sujeito. Desse modo, o objeto pode estar mais humanizado ou menos, podendo a adicção se dar tanto a uma pessoa, como a uma me- 
dicação ou droga (LAURU, 2014; CRUZ, 2012; DE RICK et al., 2009; LEBLANC et al., 2011; MATUSOW; ROSENBLUM, 2013).

$\mathrm{Na}$ dinâmica dos três pacientes, torna-se importante frisar aspectos próprios dos estados e das relações adictivas, como exacerbação da ação de tipo impulsivo e irrefreável; escravização frente ao objeto; certo grau de coisificação marcada pela degradação da relação objetal; caráter de neonecessidade do objeto; impulsividade; colapso do sonhar e, portanto, da transicionalidade e da simbolização; defesa dissociativa; patologia da dependência e sua marca passional, conforme Gurfinkel (2011) estipula como componentes distintivos das adicções, bastante próximos ou coincidentes com a condição do fronteiriço.

Dessa forma, o drama fronteiriço-adicto, presente nos casos narrados, se insere fundamentalmente no registro das relações de objeto. De acordo com Gurfinkel (2011, p. 418-419), a adicção, assim como o sofrimento borderline, consiste em lançar-se em busca de um objeto derivado de algum descaminho. Marcado por ruptura e quebra na busca do objeto, esse impulso que conduz à solução adictiva é motivado pela necessidade de sobreviver a algum fracasso da relação objetal. Contudo, o autor considera que a relação objetal está fundantemente fadada ao fracasso, pois a luta se dá, desse o início, com as mesmas armas que se mostraram ineficazes.

Tais marcas estão tragicamente presentes nas relações e no mundo dos três pacientes estudados. Neles, a adicção às pessoas, tomada a partir do sofrimento fronteiriço, aponta para a esperança de constituição de algo que não ocorreu, mas deveria ter acontecido. Essa consideração inclui o borderline na problemática de relação de objeto, análoga à dinâmica do adicto, se não coincidente com ela, ao menos nos sofrimentos expostos por Rosa, Paulo e Leonardo.

Uma marca dos casos aqui estudados, comum nesses quadros, consiste no estado contínuo de desconfiança que orbita a experiência emocional regular, uma verdade da vida baseada em falhas iniciais que tingem o destino do indivíduo com tons persecutórios, porém não nos moldes de um delírio estruturado, mas como um clima que perpassa a vida sem figuração ou símbolo. Dessa forma, o sofrimento perceptível nesses três relatos clínicos corrobora a persistência de uma percepção dolorosa de ausência do outro, miragem em um deserto sem aproximação, delírio relacional, verdade de permanente desencontro. 
Contudo, os pacientes aqui estudados dão notícias de que, ao menos em seus casos, não predominam planos de parar de caminhar, mesmo em um horizonte sem figura. Eis uma complexa relação entre ausência, risco de invasão, desmoronamento e esperança, pois fica patente o anseio de ser transformado, a perspectiva de recuperação de cuidados do ambiente identificados com as mudanças do Self. Assim, é possível conceber que a busca se dá também pela função transformadora do objeto, para além de sua presença. Com os desfechos vividos nos processos de Rosa, Paulo e Leonardo, torna-se possível pensar que, ao menos em alguns casos em que há qualidade adictiva de relação objetal, pode haver esperança e possibilidade de transformação.

Tal esperança adictiva, apresentada por Rosa, Paulo e Leonardo, parece relacionar-se à constância de um objeto, assim como à própria constituição e transformação. Portanto, os casos compreendidos como fronteiriços-adictos, compõem estados emocionais perturbados que caminham na busca por um Self (MCDOUGALL, 1992; WINNICOTT, 1975), ímpeto esperançoso de encontro e criação de presenças minimamente estáveis. Entretanto, essa busca se instala nos três casos em uma espécie de looping relacional, no qual a repetição, bem como a submissão ao externo e ao objeto, ocorre como meio de vida e impede o descanso, o trânsito pelas relações e pelas perspectivas criativas e autênticas. A partir do sofrimento desses pacientes, é possível reconhecer a relação paradoxal entre esperança e desesperança, estados estranhamente concomitantes nessa dolorosa busca. A esperança adictiva apresenta, nas três narrativas transferenciais, um desatino regressivo como tentativa de nutrição afetiva, esperança por um sinal de vida do outro, acesso a aspectos fundantes de si e do amadurecimento na direção da retificação e da inauguração de aspectos do passado. 
Capítulo VII

Considerações Finais 
Frente ao objetivo principal desta pesquisa - compreender e descrever a qualidade das relações que os pacientes fronteiriços estabelecem, bem como refletir acerca de distintos aspectos estruturais e da história de vida desses pacientes a partir de casos clínicos -, alguns pontos foram alcançados. Nesse sentido, o que se pretendia com a pesquisa foi realizado: a partir das narrativas estudadas, tornou-se possível reconhecer aspectos comuns acerca da dimensão relacional de suas vidas, principalmente suas relações adictivas. Contudo, é fundamental frisar que, frente a um tema tão amplo, o trabalho contribuiu para o destaque de tais características obtidas a partir da análise de três narrativas transferenciais.

Além disso, espera-se que este estudo promova mais questionamentos e desdobramentos do que respostas. Esta empreitada, portanto, visou construir sentidos ao focalizar um tipo específico de dor emocional e de relação, sobretudo com vistas à compreensão e ao cuidado de pessoas e sofrimentos concretos. Contudo, o objeto de pesquisa constitui terreno ainda pouco mapeado e que requer investimento na produção de trabalhos, dentro ou fora da psicanálise. Assim, sugere-se que outros estudos sejam desenvolvidos neste campo.

A partir dos casos clínicos, considerados à luz do método psicanalítico, faz-se possível a interlocução viva entre teoria, história clínica singular e encarnada, e os impactos sobre o autor do trabalho. Nesse campo intersubjetivo, foi possível realizar uma aproximação a respeito do aspecto adictivo presente em alguns pacientes fronteiriços. A abordagem do tema, dentre diversas possibilidades, foi determinada pelo impacto contratransferencial promovido pelo objeto estudado, assim como pelos aportes teóricos aqui adotados e lançados. Dessa forma, esta jornada ofereceu, sobretudo, rica oportunidade de crescimento clínico e teórico ao pesquisador-psicanalista, além da abertura para ampliação da luz sobre o tema e para novos questionamentos.

Fundamentalmente, as experiências apresentadas em forma de narrativa e analisadas por meio do método psicanalítico ofereceram subsídios para a compreensão do sofrimento contido na história pessoal e no percurso terapêutico dos participantes, sofrimento este relacionado ao vínculo ou à qualidade de relação objetal que podem ser compreendidos como adicção. Trata-se de narrativas marcadas pela impossibilidade de separação, sustentação da ausência e simbolização, condições que deram origem a expedientes dramáticos na busca de evitação compulsiva da angústia de perda objetal, do 
vazio e de experiências de desestruturação emocional. Nesse sentido, a proposta inicial foi alcançada com a compreensão de aspectos estruturais e dinâmicos desses casos, e também com o reconhecimento da marca adictiva central em suas relações.

Por fim, convém frisar que todo percurso aqui trilhado tem origem na clínica, ou seja, sofrimentos concretos instigaram a busca por compreensão e o questionamento de abordagens que entendiam tais histórias de vida como mera busca por autodestruição. Isso porque, nesse campo de múltiplos sentidos e variadas visões, qualquer classificação diagnóstica, por si só, seria incapaz de abarcar a singularidade desses sofrimentos e seus diversos sentidos. Apenas com base na consideração de sofrimentos concretos e de seu impacto no outro, em um campo intersubjetivo, é que sentidos e compreensões puderam ser construídos a fim de incrementar perspectivas clínicas e teóricas que contribuam para o cuidado de pessoas. 


\section{Capítulo VIII}

\section{Referências Bibliográficas}


ABRAHAM, K. As relações psicológicas entre a sexualidade e o alcoolismo. A direção da cura nas toxicomanias. Revista da Associação Psicanalítica de Porto Alegre, Porto Alegre, n. 24, p. 111-120, mai. 2003. Publicado originalmente em 1908.

Breve estudo do desenvolvimento da libido, visto à luz das perturbações mentais. In:___. Teoria psicanalítica da libido. Sobre o caráter e o desenvolvimento da libido. Rio de Janeiro: Imago, 1970. p. 81-160. Publicado originalmente em 1924.

AIELLO-VAISBERG, T. M. J. Encontro com a loucura: Transicionalidade e ensino de psicopatologia. 1999. 342 f. Tese (Livre-Docência em Psicologia) - Instituto de Psicologia, Universidade de São Paulo, São Paulo, 1999.

O uso do objeto teoria. In: AIELLO-VAISBERG T. M. J.; AMBROSIO F. F. (Org.). Ser e Fazer: Enquadres diferenciados na clínica winnicottiana. Aparecida-S.P.: Ideias e letras, 2004b. p. 185-204 (Coleção Psi-Atualidades, 3). Publicado originalmente em 1999.

Preconceito, exclusão e perversão social: Pesquisa psicanalítica sobre potencialidade mutativa de práticas psicológicas em instituições. Grupo de pesquisa Atenção Psicológica em Instituições: Prevenção e Intervenção. Projeto temático para orientação de iniciações científicas e mestrados e doutorados do Programa de Pós-Graduação em Psicologia da Pontifícia Universidade Católica de Campinas, 2007.

Ser e Fazer: Interpretação e intervenção na clínica winnicottiana. In: AIELLOVAISBERG T. M. J.; AMBROSIO F. F. (Org.). Ser e Fazer: Enquadres diferenciados na clínica winnicottiana. Aparecida-SP: Ideias e Letras, 2004a. p. 23-58. (Coleção PsiAtualidades, 3)

. Sofrimento humano e exclusão social: Pesquisa de enquadres diferenciados para abordagem psicanalítica preventiva de condutas preconceituosas. Projeto de pesquisa. Pontifícia Universidade Católica de Campinas, 2006.

AIELlO-VAISBERG, T. M. J.; MACHADO, M. C. L. Diagnóstico estrutural de personalidade em psicopatologia psicanalítica. Psicologia USP, São Paulo, v. 11, n. 1, 2000. Disponível em $<$ http://www.scielo.br/scielo.php?script=sci_arttext\&pid=S010365642000000100003\&lng=en\&nrm=iso>. Acesso em 25 fev. 2012. http://dx.doi.org/10.1590/S0103-65642000000100003.

AIELlO-VAISBERG, T. M. J.; MACHADO, M. C. L.; AYOUCH, T.; CARON, R.; BEAUNE, D. Les récits transferenciels comme presentation du vécu clinique: Une proposition méthodologique. In: BEAUNE, D. (Org.). Psychanalyse, philosophie, art: Dialogues. Paris: L'Harmattan, 2009. V. 1, p. 39-52. 
ALCANTARA, I. et al. Avanços no diagnóstico do transtorno do humor bipolar. Revista de Psiquiatria do Rio Grande do Sul, Porto Alegre, v. 25, supl. 1, p. 22-32, abr. 2003. Disponível em $<$ http://www.scielo.br/scielo.php?script=sci_arttext\&pid=S0101$81082003000400004 \& \operatorname{lng}=$ en\&nrm=iso $>$. Acesso em 17 jan. 2016. http://dx.doi.org/10.1590/S0101-81082003000400004.

ALMEIDA-PRADO, M. do C. C. de; FERES-CARNEIRO, T. Violência familiar: Obesidade mórbida e função ômega. Revista Latinoamericana de Psicopatologia Fundamental, São Paulo, v. 13, n. 2, p. 190-206, jun. 2010. Disponível em $<$ http://www.scielo.br/scielo.php?script=sci_arttext\&pid=S1415$47142010000200003 \& \operatorname{lng}=$ en\&nrm=iso $>$. Acesso em 17 jan. 2016. http://dx.doi.org/10.1590/S1415-47142010000200003.

ALVES-MAZOTTI, A. J. Usos e abusos de estudos de caso. Cadernos de Pesquisa, São Paulo, n. 36, p. 637-651, set.-dez. 2006.

AUDIBERT, C. Sur les addictions. Paris: Payot, 2008.

BALINT, M. A falha básica. Porto Alegre: Artes Médicas, 1993. Publicado originalmente em 1968.

BAZAN A., DETANDT, S. On the physiology of jouissance: Interpreting the mesolimbic dopaminergic reward functions from a psychoanalytic perspective. Frontiers in Human Neuroscience, Lausanne, vol. 7, art. 709, 6 nov. 2013. doi: 10.3389/fnhum.2013.00709.

BENDAT, M. In name only? Mental health parity or illusory reform. Psychodynamic Psychiatry, Nova York, vol. 42, n. 3, Fall 2014, p. 353-375. doi: 10.1521/pdps.2014.42.3.353.

BERCHERIE P. Os fundamentos da clínica: História e estrutura do saber psiquiátrico. Rio de Janeiro: Jorge Zahar Editor, 1980.

BERGERET, J. A personalidade normal e patológica. 3. ed. Porto Alegre: Artmed, 1998.

. La dépression et les états limites. Paris: Payot. 1975.

Psicopatologia: teoria e clínica. Porto Alegre: Artmed, 2006. 
BERGERET, J.; LEBLANC, J. Toxicomanias: Uma visão multidisciplinar. Porto Alegre: Artmed, 1991.

BERGERET, J.; REID, W. Narcissisme et états limites. Paris: Dunod, 1986.

BERNER, W, BRIKEN, P. Pleasure seeking and the aspect of longing for an object in perversion: A neuropsychoanalytical perspective. American Journal of Psychotherapy, Nova York, v. 66, n. 2, p. 129-150, 2012.

BLEGER, J. Psicologia da conduta. Porto Alegre: Artes Médicas, 1984. Publicado originalmente em 1963.

BOLLAS, C. Hysteria. São Paulo: Escuta, 2000.

O objeto transformacional. In: KOHON, G. (Org.). A escola britânica de psicanálise: The Middle Group, a tradição independente. Porto Alegre: Artes Médicas, 1994. p. 63-75.

Forças do destino: Psicanálise e idioma humano. Rio de Janeiro, Imago, 1992.

BRADLEY, R.; WESTEN, D. The psychodynamics of borderline personality disorder: A view from developmental psychopathology. Development and Psychopathology, Nova York, v. 17, n. 4, p. 927-957, Fall 2005. doi:10.1017/S0954579405050443.

BRUSSET, B. Dépendance addictive et dépendance affective. Revue Française de Psychanalyse, Paris, v. 68, n. 2, p. 405-420, fev. 2004.

CAIXETA, M. Tipos clínicos psicopatológicos associados ao tabagismo. Arquivos de Neuro-Psiquiatria, São Paulo, v. 50, n. 2, p. 241-243, jun. 1992. Disponível em $<$ http://www.scielo.br/scielo.php?script=sci_arttext\&pid=S0004282X1992000200022\&lng=pt\&nrm=iso>. Acesso em 27 out. 2014. http://dx.doi.org/10.1590/S0004-282X1992000200022.

CARDOSO, M. R. A impossível "perda" do outro nos estados limites: Explorando as noções de limite e alteridade. Psicologia em Revista (Belo Horizonte), Belo Horizonte, v. 13, n. 2, p. 325-338, dez. 2007. Disponível em <http://pepsic.bvsalud.org/scielo.php? script $=$ sci_arttext\&pid $=\mathrm{S} 1677-11682007000200008 \& \operatorname{lng}=\mathrm{pt} \& \mathrm{nrm}=\mathrm{iso}>$. Acesso em 31 jan. 2016.

A servidão ao "outro" nos estados limites. Psyche (São Paulo), São Paulo, v. 9, n. 16, p. 65-75, dez. 2005. Disponível em $<$ http://pepsic.bvsalud.org/scielo.php?script= 
sci_arttext\&pid=S1415-11382005000200005\&lng=pt\&nrm=iso $>$. Acesso em 31 jan. 2016.

CARVALHO, A. F.; STRACKE, C. B.; SOUZA, F. G. de M. Tratamento farmacológico do transtorno de personalidade limítrofe: Revisão crítica da literatura e desenvolvimento de algoritmos. Revista de Psiquiatria do Rio Grande do Sul, Porto Alegre, v. 26, n. 2, p. 176-189, ago. 2004. Disponível em <http://www.scielo.br/scielo.php?script= sci_arttext\&pid=S0101-81082004000200007\&lng=pt\&nrm=iso $>$. Acesso em 27 out. 2014. http://dx.doi.org/10.1590/S0101-81082004000200007.

CASTELLO-BRANCO, I. Corpo e destrutividade: A construção de um limite. Revista Latinoamericana de Psicopatologia Fundamental, São Paulo, v. 7, n. 4, p. 44-58, dez. 2004.

CASTRO MORALES, J. Autolesión no suicida en adolescentes peruanas: Una aproximación diagnóstica y psicopatológica. Revista de Neuropsiquiatría, Lima, v. 77, n. 4, oct. 2014 . Disponível em <http://www.scielo.org.pe/scielo.php?script=sci_arttext \&pid=S0034-85972014000400005\&lng=es\&nrm=iso>. Acesso em 17 jan. 2016.

CESAROTTO, O. Um affair freudiano. São Paulo: Iluminuras, 1989.

CHABERT, C. Les fontionnements limites: Quelles limites? In: ANDRÉ, J. Les états limites: Nouveau paradigme pour la psychanalyse? Paris: Presses Universitaires de France, 1999. p. 93-121.

CHABERT, C.; VERDON, B. Psychologie clinique et psychopathologie. Paris: Presses Universitaires de France, 2008.

CHAGNON, J. Y. Os estados-limite nos trabalhos psicanalíticos franceses. Psicologia USP, São Paulo, v. 20, n. 2, jun. 2009. Disponível em <http://www.scielo.br/scielo.php? script $=$ sci_arttext\&pid $=$ S0103-65642009000200003\&lng $=$ pt\&nrm=iso $>$. Acesso em 27 out. 2014. http://dx.doi.org/10.1590/S0103-65642009000200003.

CHAUVET, E. L'addiction à l'objet: Une dépendance passionelle. Revue Française de Psychanalyse, Paris, v. 68, n. 2, p. 609-622, fev. 2004.

COSTA, M.; MOTA, C. P.; MILHEIRO, C. Abordagem psicodinâmica em um estudo de caso sobre transtorno de personalidade borderline. Psicologia: Teoria e Prática, São Paulo, v. 15, n. 3, p. 19-33, dez. 2013. Disponível em <http://pepsic.bvsalud.org/ scielo.php?script $=$ sci_arttext\&pid $=\mathrm{S} 1516-36872013000300002 \& \operatorname{lng}=\mathrm{pt} \& \mathrm{nrm}=\mathrm{iso}>$. Acesso em 31 jan. 2016. 
CRUZ, M. S.; TARDIVO, L. S. P. C. O colapso da transicionalidade: Aproximações entre a personalidade borderline e as adicções. Revista Rabisco, Porto Alegre, v. 3, n. 1, p. 146-152, mai. 2013.

CRUZ, M. S. Reflexões sobre a relação entre a personalidade bordeline e as adicções. 2012. 132 f. Dissertação (Mestrado em Psicologia Clínica) - Instituto de Psicologia, Universidade de São Paulo, São Paulo, 2012. Disponível em: < http://www.teses.usp.br/ teses/disponiveis/47/47133/tde-14062012-154805/>. Acesso em: 26 out. 2014.

CRUZ, W. F. de O.; VIANA, T. de C. Limites: A questão do manejo clínico hoje. Psicologia Clínica, Rio de Janeiro, v. 24, n. 2, p. 27-41, dez. 2012. Disponível em $<$ http://www.scielo.br/scielo.php?script=sci_arttext\&pid=S0103-56652012000200003 \&lng=pt\&nrm=iso $>$. Acesso em 27 out. 2014. http://dx.doi.org/10.1590/S010356652012000200003.

CUNHA, P. J.; AZEVEDO, M. A. S. B. de. Um caso de transtorno de personalidade borderline atendido em psicoterapia dinâmica breve. Psicologia: Teoria e Pesquisa, Brasília, v. 17, n. 1, p. 5-11, abr. 2001. Disponível em <http://www.scielo.br/ scielo.php?script $=$ sci_arttext\&pid=S0102-37722001000100003\&lng=pt\&nrm=iso $>$. Acesso em 27 out. 2014. http://dx.doi.org/10.1590/S0102-37722001000100003.

DALBUDAK, E. et al. The severity of Internet addiction risk and its relationship with the severity of borderline personality features, childhood traumas, dissociative experiences, depression and anxiety symptoms among Turkish University Students. Psychiatry Research, Amsterdã, v. 219, n. 3, p. 577-582, 30 nov. 2014.

DAL'PIZOL, A. et al. Programa de abordagem interdisciplinar no tratamento do transtorno de personalidade borderline: Relato da experiência no ambulatório Melanie Klein do Hospital Psiquiátrico São Pedro. Revista de Psiquiatria do Rio Grande do Sul, Porto Alegre, v. 25, supl. 1, p. 42-51, abr. 2003. Disponível em <http://www.scielo.br/ scielo.php?script $=$ sci_arttext\&pid=S0101-81082003000400006\&lng=en\&nrm=iso $>$. Acesso em 27 jun. 2015. http://dx.doi.org/10.1590/S0101-81082003000400006.

DALGALARRONDO, P.; VILELA, W. A. Transtorno borderline: História e atualidade. Revista Latinoamericana de Psicopatologia Fundamental, São Paulo, v. 2, n. 2, p. 52-71, jun. 1999.

DALÓ, L. H. O. A escrita dos estados-limite como um recurso de ampliação da escuta psicanalítica. 2012. 114 f. Dissertação (Mestrado em Psicologia Escolar e do Desenvolvimento Humano) - Instituto de Psicologia, Universidade de São Paulo, São Paulo, 2012. Disponível em: <http://www.teses.usp.br/teses/disponiveis/47/47131/tde03122012-105144/>. Acesso em 26 de out. 2014. 
DIAS, E.O. A teoria do amadurecimento de D.W Winnicott. Rio de Janeiro: Imago, 2003.

DIAS, Elsa Oliveira. O uso da interpretação na clínica do amadurecimento. Revista Latinoamericana de Psicopatologia Fundamental, São Paulo , v. 11, n. 4, p. 588601, dez. 2008. Disponível em $<$ http://www.scielo.br/scielo.php?script=sci_arttext\&pid $=\mathrm{S} 1415-47142008000400006 \& \operatorname{lng}=\mathrm{en} \& \mathrm{nrm}=\mathrm{iso}>$. Acesso em 17 jan. 2016 . http://dx.doi.org/10.1590/S1415-47142008000400006.

DINAMARCO, A. V. Análise exploratória sobre o sintoma de automutilação praticada com objetos cortantes elou perfurantes, através de relatos expostos na internet por um grupo brasileiro que se define como praticante de automutilação. 2011. 117 f. Dissertação (Mestrado em Psicologia Clínica) - Instituto de Psicologia, Universidade de São Paulo, São Paulo, 2011. Disponível em: <http://www.teses.usp.br/teses/disponiveis/47/ 47133/tde-06092011-162704/>. Acesso em 23 de jan. 2016.

DEUTSCH, H. Some forms of emotional disturbance and their relationship to schizophrenia. In: . Essential papers on borderline disorders. Nova York: NY Univerity Press, 1986. p. 74-93. Publicado originalmente em 1942.

DE RICK A.; VANHEULE S.; VERHAEGHE, P. Alcohol addiction and the attachment system: An empirical study of attachment style, alexithymia, and psychiatric disorders in alcoholic inpatients. Substance Use \& Misuse, Londres, v. 44, n. 1, p. 99-114, jul. 2009. doi: 10.1080/10826080802525744.

DE RICK, A.; VANHEULE, S. Attachment styles in alcoholic inpatients. European Addiction Research, Basileia, v. 13, n. 2, p. 101-108, mar. 2007.

EAGLETON, T. Depois da teoria: Um olhar sobre os estudos culturais e o pósmodernismo. Rio de Janeiro: Civilização Brasileira, 2005.

EIZIRIK, M.; FONAGY, P. Mentalization-based treatment for patients with borderline personality disorder: An overview. Revista Brasileira de Psiquiatria, São Paulo, v. 31, n. 1, p. 72-75, mar. 2009. Disponível em $<$ http://www.scielo.br/scielo.php?script= sci_arttext\&pid=S1516-44462009000100016\&lng=pt\&nrm=iso $>$. Acesso em 27 out. 2014. http://dx.doi.org/10.1590/S1516-44462009000100016.

ESSIG, T. The addiction concept and technology: Diagnosis, metaphor, or something else? A psychodynamic point of view. Journal of Clinical Psychology, Nova York, v. 68, n. 11, p. 1175-1184, nov. 2012. doi: 10.1002/jclp.21917. Epub 13 set. 2012.

ESCOHOTADO, A. Historia de las drogas. Alianza Editorial: Madrid, 1996. 
ESQUIROL, J.-É.-D. Des maladies mentales. Paris: Frénésie Editions, 1989.

ESTELLON, V.; MOURAS, H. Sexual addiction: Insights from psychoanalysis and functional neuroimaging. Socioaffective Neuroscience \& Psychology, Bethesda, v. 2, n. do art. 11814, 20 jan. 2012. doi: 10.3402/snp.v2i0.11814. eCollection 2012.

EUFRASINO, C. C. V. Profundidade superficial e superficialidade profunda: O dilema da pesquisa em ciências humanas entre a disciplinaridade e a interdisciplinaridade. Em Questão, Porto Alegre, v. 14, n. 1, p. 107-112, jan.-jun. 2008.

FAIRBAIRN, W. R. D. Relaciones objectales y estrutura dinâmica. In: Estudio psicoanalitico de la personalidad. Buenos Aires: Ediciones Hormé, 2013. p. 329-333. Publicado originalmente em 1946.

FÉDIDA, P. Dos benefícios da depressão: Elogio da psicoterapia. São Paulo: Escuta, 2002. . Nome, figura e memória: A linguagem na situação analítica. São Paulo: Escuta, 1991.

FENICHEL, O. Teoria psicanalitica das neuroses. Rio de Janeiro: Atheneu, 1945.

FERENCZI, S. Confusão de língua entre os adultos e a criança. In Psicanálise IV. São Paulo: Martins Fontes, 1992. p. 97-106. Originalmente publicado em 1933.

FERNANDEZ-MONTALVO, J.; LOREA, I. Comorbilidad de la adicción a la cocaína con los trastornos de la personalidad. Anales del Sistema Sanitario de Navarra, Pamplona, v. 30, n. 2, p. 225-231, ago. 2007. Disponível em <http://scielo.isciii.es/ scielo.php?script $=$ sci_arttext\&pid=S1 137-66272007000300007\&lng=es\&nrm=iso $>$. Acesso em 17 jan. 2016.

FIGUEIREDO, L. C. A clínica borderline. In: Elementos para a psicanálise contemporânea. São Paulo: Escuta, 2003. p. 109-126.

Sense of reality, reality testing and reality processing in borderline patients. International Journal of Psycho-Analysis, Londres, v. 87, n. 3, p. 769-787, jun. 2006.

FONAGY, P. The mentalization-focused approach to social development. In: ALLEN, J. G.; FONAGY, P. (Orgs.). Handbook of mentalization-based treatment. London: John Wiley \& Sons, 2006. p. 440-454. 
FREIRE, C. M. R. C. O diagnóstico e suas diferentes aplicações no manejo clínico: Uma ressalva. In: SILVEIRA, D. X.; MOREIRA, F. G. Panorama atual de drogas e dependências. São Paulo: Atheneu, 2006. p. 222-227.

FREUD, S. A interpretação dos sonhos. In: Edição standard brasileira das obras psicológicas completas. Rio de Janeiro: Imago, 1996. V. 4 e 5, p. 17-730. Publicado originalmente em 1900.

Além do princípio do prazer. In: . Edição standard brasileira das obras psicológicas completas. Rio de Janeiro: Imago, 1996. V. 18, p. 17-78. Publicado originalmente em 1920.

Análise de uma fobia em um menino de cinco anos. In: . Edição standard brasileira das obras psicológicas completas. Rio de Janeiro: Imago, 1996. V. 10, p. 137-205. Publicado originalmente em 1909.

Dois verbetes de enciclopédia: Psicanálise e Teoria da libido. In: Edição standard brasileira das obras psicológicas completas. Rio de Janeiro: Imago, 1996. V. 18, p. 251-271. Publicado originalmente em 1922.

. Formulações sobre os dois princípios do funcionamento mental. In:

Edição standard brasileira das obras psicológicas completas. Rio de Janeiro: Imago, 1996. V. 12, p. 233-246. Publicado originalmente em 1911.

Delírios e sonhos na Gradiva de Jensen. In: Edição standard brasileira das obras psicológicas completas. Rio de Janeiro: Imago, 1996. V. 9, p. 15-90. Publicado originalmente em 1907.

História de uma neurose infantil (“O homem dos lobos"). In: Obras completas. São Paulo: Companhia das Letras, 2010. V. 18, p. 157-183. Publicado originalmente em 1914.

. Luto e melancolia. In: Edição standard brasileira das obras psicológicas completas. Rio de Janeiro: Imago, 1996. V. 14, p. 75-108. Publicado originalmente em 1917.

Sobre transformações dos instintos, em particular no erotismo anal. In:

História de uma neurose infantil ("O homem dos lobos"), Além do princípio do prazer e outros textos (1917-1920). Tradução Paulo César de Souza. São Paulo: Companhia das Letras, 2010. (Obras completas, 14). p. 165-187. Publicado originalmente em 1917. 
. Tipos libidinais. In: . Edição eletrônica brasileira das obras psicológicas completas de Sigmund Freud. Rio de Janeiro: Imago, 1992. CD-ROM. Publicado originalmente em 1931.

Um caso de histeria. In: Edição standard brasileira das obras psicoló-

gicas completas. Rio de Janeiro: Imago, 1996. V. 7, p. 15-118. Publicado originalmente em 1905.

GABBARD, G. O. Psiquiatria psicodinâmica: Baseado no DSM-IV. Porto Alegre: Artmed, 1998. Cap. 15, p. 296-324.

GABBERT T. G. The application of the theory of narcissism in criminal proceedings (forensic theory of narcissism). Archiv für Kriminologie, Lübeck, v. 224, n. 3-4, p. 116126, set.-out. 2009.

GARCIA, M. C. C. C. Anorexia e bulimia na clínica psicanalítica: Um estudo a partir da obra de Didier Anzieu. 2015. 91 f. Tese (Doutorado) - Instituto de Psicologia, Universidade de São Paulo, São Paulo, 2015.

GARCIA LOPEZ, M. T.; MARTIN PEREZ, M. F.; OTIN LLOP, R. Tratamiento integral del trastorno límite de personalidad. Revista de la Associación Española de Neuropsiquiatría, Madrid, v. 30, n. 2, p. 263-278, jun. 2010 . Disponível em $<$ http://scielo. isciii.es/scielo.php?script $=$ sci_arttext\&pid=S0211-57352010000200005\&lng=es\&nrm =iso $>$. Acesso em 17 jan. 2016.

GARCIA-ROZA, L. A. Pesquisa de tipo teórico. Psicanálise e Universidade, São Paulo, v.1, p. 9-32, 1994.

GARCIANDIA IMAZ, J. A. Secuestro y psicopatología: Lo monstruoso. Revista Colombiana de Psiquiatría, Bogotá, v. 40, n. 3, p. 577-598, set. 2011 . Disponível em $<$ http://www.scielo.org.co/scielo.php?script=sci_arttext\&pid=S0034$74502011000300015 \& \operatorname{lng}=$ en\&nrm=iso>. Acesso em 17 Jan. 2016.

GLOVER, E. On an aetiology of drug-addiction. In: YALISOVE, D. (Ed.). Essential papers on addiction. Nova York: NY University Press, 1997. p. 24-51. Publicado originalmente em 1932.

GRANATO, T. M. M.; AIELLO-VAISBERG T. M. J. Tecendo a pesquisa clínica em narrativas psicanalíticas. Mudanças, São Bernardo do Campo, v. 12, n. 2, p. 253-271, jul-dez 2004. 
GREEN, A. Conferências brasileiras de André Green: Metapsicologia dos limites. Rio de Janeiro: Imago, 1990.

. Génesis y situación de los estados fronterizos. In: ANDRÉ, J. Los estados fronterizos: Nuevo paradigma para el psicoanálisis? Buenos Aires: Claves, 1999. p. 27-61.

. Histeria e estados-limite: Quiasma. Novas perspectivas. Revista Brasileira de Psicanálise, São Paulo, v. XXXVI, n. 3, p. 465-86, jul.-set. 2002.

. Narcisismo de vida, narcisismo de morte. São Paulo: Escuta, 1988a.

. O discurso vivo: Uma teoria psicanalítica do afeto. Rio de Janeiro: Editora Francisco Alves, 1982. Publicado originalmente em 1973.

Pulsão de morte, narcisismo negativo e função desobjetalizante. In: YORKE, C. et al. A pulsão de morte. São Paulo: Escuta, 1988c. p. 57-68.

. Sobre a loucura pessoal. Rio de Janeiro: Imago,1988b. Publicado originalmente em 1977.

GREENBERG, J. R.; MITCHELL, S. A. Relações objetais na teoria psicanalítica. Porto Alegre: Artes Médicas, 1994.

GRINKER, R. R.; WERBLE, B.; DRYE, R. C. The borderline syndrome: A behavioral study of ego functions. New York: Basic Books, 1968.

GUERRESCHI, C. New addictions: As novas dependências. São Paulo: Paulus, 2007.

GUNDERSON J.G. borderline personality disorder. Washington, DC: American Psychiatric Press, 1984.

GURFINKEL, D. Adicções: Paixão e vício. São Paulo: Casa do Psicólogo, 2011.

A clínica do agir. In: VOLICH, R. M.; FERRAZ, F. C.; RANÑA, W. (Orgs.).

Psicossoma IV: Corpo, história, pensamento. Casa do Psicólogo, 2008. p. 433-455.

. Do sonho ao trauma: Psicossoma e adicções. São Paulo: Casa do Psicólogo, 2001.

. Pulsão e seu objeto-droga: Estudo psicanalítico sobre as toxicomanias. São

Paulo: Vozes, 1995. 
GUTTON, P. Dépressivité et stratégies dépressives. Adolescence, Paris, v. 4, n. 2, p.171-178, set. 1986.

HEGENBERG, M. Borderline. São Paulo: Casa do Psicólogo, 2000.

HENRIQUES-CALADO, J. et al . Perturbações da personalidade como expressão dimensional da personalidade em mulheres idosas. Psicologia, Saúde \& Doenças, Lisboa, v. 14, n. 2, p. 288-294, jul.-dez. 2013 . Disponível em <http://www.scielo.mec.pt/ scielo.php?script $=$ sci_arttext\&pid $=\mathrm{S} 1645-00862013000200005 \& \operatorname{lng}=\mathrm{pt} \& \mathrm{nrm}=\mathrm{iso}>$. Acesso em 16 jan. 2016.

HERRMANN, F. O método da psicanálise. São Paulo: EPU, 1979.

Pesquisando com o método psicanalítico. In: Pesquisando com o método psicanalítico. Organizadores: Herrmann, F.; Lowenkron, T. São Paulo: Casa do Psicólogo, 2004. 43-83.

O que é psicanálise: Para iniciantes ou não. São Paulo: Psique, 1999.

HOCH, P.; POLATIN P. Pseudoneurotic forms of schizophrenia. The Psychiatric Quarterly, Nova York, v. 23, n. 2, p. 248-276, abr. 1949.

HOFFMANN, C.; COSTA, R. A. Alguns casos, nem neuróticos, nem abertamente psicóticos. Ágora (Rio de Janeiro), Rio de Janeiro, v. 17, n. 2, p. 247-253, dez. 2014. Disponível em $<$ http://www.scielo.br/scielo.php?script=sci_arttext\&pid=S151614982014000200006\&lng=en\&nrm=iso $>$. Acesso em 17 jan. 2016. http://dx.doi.org/10.1590/S1516-14982014000200006.

HOLMES, J. Borderline personality disorder and the search for meaning: An attachment perspective. Australian and New Zealand Journal of Psychiatry, Carlton South, Vic., v. 37, n. 5, p. 524-531, out. 2003.

HOUAISS, A.; VILLAR, M. de S. Dicionário Houaiss da língua portuguesa. Rio de Janeiro: Objetiva, 2001.

HUGHES, C. Borderland psychiatric records: Prodromal symptoms of psysical impairment. Alienist and Neurologist, v. 5, p. 85-91, 1884.

HUMBERG, L. V. Dependência do vínculo: Uma releitura do conceito de codependência. 2003. 142 f. Dissertação (Mestrado em Fisiopatologia Experimental) Faculdade de Medicina, Universidade de São Paulo, São Paulo, 2004. Disponível em: 
$<$ http://www.teses.usp.br/teses/disponiveis/5/5160/tde-18102005-105706/>. Acesso em 23 jan. 2016.

Relacionamentos Adictivos: Um estudo psicanalítico. 2014. 302 f. Tese

(Doutorado em Psicologia) - Instituto de Psicologia, Universidade de São Paulo, São Paulo, 2014. Disponível em $<$ http://www.teses.usp.br/teses/disponiveis/47/47134/tde27032015-125322/pt-br.php> Acesso em 23 jan. 2016.

JACOBSON, E. The return of the lost parent. In: FRANKIEL, R. V. (Ed.). Essential papers on object loss. Nova York: NY University Press, 1994. p. 233-250. Publicado originalmente em 1964.

JASPERS, K. A abordagem fenomenológica em psicopatologia. Revista Latinoamericana de Psicopatologia Fundamental, São Paulo, vol. VIII, n. 4, p. 769-787, dez. 2005. Original publicado em 1912.

JOHNSON, B. Addiction and will. Frontiers in Human Neuroscience, Lausanne, v. 7, art. 545, p. 1-11, set. 2013. doi: 10.3389/fnhum.2013.00545. eCollection 2013.

Psychoanalytic treatment of psychological addiction to alcohol (alcohol abuse).

Frontiers in Psychology, Lausanne, v. 2, art. 362, p. 1-10, dez. 2011. doi: 10.3389/fpsyg.2011.00362. eCollection 2011.

JORDÃO, A. B.; RAMIRES, V. R. R. Adolescência e organização de personalidade borderline: Caracterização dos vínculos afetivos. Paidéia (Ribeirão Preto), Ribeirão Preto, v. 20, n. 47, p. 421-430, dez. 2010. Disponível em <http://www.scielo.br/ scielo.php?script $=$ sci_arttext\&pid $=\mathrm{S} 0103-863 \mathrm{X} 2010000300014 \& \operatorname{lng}=\mathrm{en} \& \mathrm{nrm}=\mathrm{iso}>$. Acesso em 17 jan. 2016. http://dx.doi.org/10.1590/S0103-863X2010000300014.

. Vínculos afetivos de adolescentes borderline e seus pais. Psicologia: Teoria e Pesquisa, Brasília, v. 26, n. 1, mar. 2010. Disponível em <http://www.scielo.br/ scielo.php?script $=$ sci_arttext\&pid $=\mathrm{S} 0102-37722010000100011 \& \operatorname{lng}=\mathrm{pt} \& \mathrm{nrm}=\mathrm{iso}>$. Acesso em 27 out. 2014. http://dx.doi.org/10.1590/S0102-37722010000100011.

JUNQUEIRA, C. Rumo à “metapsicologia dos limites”: O diálogo possível entre a teoria pulsional e a teoria das relações de objeto e algumas de suas consequências Freud, Winnicott e Green. 2010. 189 f. Tese (Doutorado em Psicologia Experimental) - Instituto de Psicologia, Universidade de São Paulo, São Paulo, 2010. Disponível em: $<$ http://www.teses.usp.br/teses/disponiveis/47/47132/tde-16042010-113841/>. Acesso em 23 jan. 2016. 
JUNQUEIRA, C.; COELHO JUNIOR, N. E. Freud e as neuroses atuais: As primeiras observações psicanalíticas dos quadros borderline? Psicologia Clínica, Rio de Janeiro, v. 18 , n. 2, p. 25-35, 2006. Disponível em $<$ http://www.scielo.br/scielo.php?script= sci_arttext\&pid=S0103-56652006000200003\&lng=pt\&nrm=iso $>$. Acesso em 27 out. 2014. http://dx.doi.org/10.1590/S0103-56652006000200003.

KALINA, E.; KOVADLOFF, S.; ROIG, P. M.; SERRAM, J. C.; CESARMAN, F. Drogadicção hoje: Indivíduo, família e sociedade. Porto Alegre: Artes Médicas, 1999.

KALLAS, R. G. M. Adicção a drogas e funcionamentos limites: Suas expressões e convergências no Rorschach. 2012. 140 f. Tese (Doutorado em Psicologia Clínica) - Instituto de Psicologia, Universidade de São Paulo, São Paulo, 2012. Disponível em: $<$ http://www.teses.usp.br/teses/disponiveis/47/47133/tde-18122012-084906/>. Acesso em 26 de out. 2014.

Do psicodiagnóstico à intervenção em adictos: Contribuições do Rorschach e do atendimento clínico. 2007. 305 f. Dissertação (Mestrado em Psicologia Clínica) - Instituto de Psicologia, Universidade de São Paulo, São Paulo, 2007. Disponível em: $<$ http://www.teses.usp.br/teses/disponiveis/47/47133/tde-19062008-094323/>. Acesso em 27 de out. 2014.

KAPLAN, H. I.; SADOCK, B. J.; GREBB, J. A. Transtornos de personalidade. In: Compêndio de psiquiatria: ciências do comportamento e psiquiatria clínica. Porto Alegre: Artes Médicas, 1997. Cap. 26, p. 686-706.

KEMP, R. The symbolic constitution of addiction: Language, alienation, ambivalence. Health (Londres), Londres, v. 16, n. 4, p. 434-447, jul. 2012. doi: 10.1177/ 1363459311425515. Epub 2011 Dec 22.

KERNBERG, O. F.; YEOMANS, F. E.; CLARKIN, J. F. Psychotherapy for borderline personality: Focusing on object relations. Washington: APP, 2006.

KERNBERG, O. F.; SELZER, M. A.; KOENSIGSBER, H. W. A agressão nos transtornos de personalidade e nas perversões. Porto Alegre: Artes Médicas, $1995 \mathrm{~b}$.

Borderline conditions and pathological narcissism. Nova York: Arenson, 1975.

La transferencia y la contratransferência en el tratamento de pacientes fronterizos. In: KERNBERG, O. F. (Org.). La teoria de las relaciones objetales y el psicoanálisis clínico. Argentina: Paidós, 1979a. p. 45-54. 
Principios generales del tratamento. In: KERNBERG, O. F. (Org.). Desordens

fronterizos y narcisisismo patológico. Buenos Aires: Paidós, 1979b. p.73-106.

. Psicoterapia dinâmica de pacientes borderlines. Porto Alegre: ArtMed, 1991.

. Severe personality disorders. Nova York: Jason Aronson, 1984.

. Technical considerations in the treatment of borderline personality organization. Journal of the American Psychoanalytic Association, Nova York, v. 24, n. 4, p. 795-829, ago. 1976.

. Transtornos graves de personalidade. Porto Alegre: Artmed, 1995a.

KLEIN, M. Mourning and its relation to manic-depressive states. In: FRANKIEL, R. V. (Ed.). Essential papers on object loss. Nova York: NY University Press, 1994. p. $95-$ 122. Publicado originalmente em 1940.

KNIGHT, R. P. Borderline states. In: STONE, M. H. (Ed.). Essential papers on borderline disorders: One hundred years at the border. Nova York: NY Univerity Press, 1986. p. 159-173. Originalmente publicado em 1953.

KOHUT, H. Análise do self. Rio de Janeiro: Imago, 1988. Publicado originalmente em 1971.

KON, N. M. Freud e seu duplo. São Paulo: EDUSP/ FAPESP, 1996.

KRADIN, R. Converting a Freudian analysis into a Jungian one: Obsession, addiction, and an answer from Job. Journal of Analytical Psychology, Oxford, n. 59, v. 3, p. 346365, jun. 2014. doi: 10.1111/1468-5922.12082.

LACAN, J. Escritos. Rio de Janeiro: Zahar, 1998. Originalmente publicado em 1966.

LAPLANCHE, J.; PONTALIS, J. B. Vocabulário de psicanálise. São Paulo: Martins Fontes, 2001.

LAURU, D. Etat limite, adolescence, cannabis et cocaïne. Ágora (Rio de Janeiro), Rio de Janeiro, v. 17, n. especial, p. 11-22, ago. 2014. Disponível em $<$ http://www.scielo.br/ scielo.php?script $=$ sci_arttext\&pid $=\mathrm{S} 1516-14982014000300002 \& \operatorname{lng}=\mathrm{en} \& \mathrm{nrm}=\mathrm{iso}>$. Acesso em 16 jan. 2016. http://dx.doi.org/10.1590/S1516-14982014000300002. 
LEBLANC, J.-S.; RENAUD, S.; WAHBI, A.; CLOUTIER, J. Attachement insécure/désorganisé et trouble de personnalité limite: Peut-on sortir de l'impasse thérapeutique? Santé Mentale au Québec, Quebec, v. 36, n. 2, p. 145-159, outono 2011.

LE POULICHET, S. Toxicomanías y psicoanálisis: Las narcosis del deseo. Buenos Aires-Madrid: Amorrortu, 2005.

LINO DA SILVA, M. E. Pensar em psicanálise. In: (Org.). Investigação e psicanálise. São Paulo: Papirus, 1993. p. 11-26.

LIONÇO, T. Corpo somático e psiquismo na psicanálise: Uma relação de tensionalidade. Ágora (Rio de Janeiro), Rio de Janeiro, v. 11, n. 1, p. 117-136, jun. 2008. Disponível em $<$ http://www.scielo.br/scielo.php?script=sci_arttext\&pid=S1516$14982008000100008 \& \operatorname{lng}=p t \& n r m=$ iso $>$. Acesso em 27 out. 2014. http://dx.doi.org/10.1590/S1516-14982008000100008.

LEMOS HOYOS, M.; LONDONO ARREDONDO, N. H. Construcción y validación del cuestionario de dependencia emocional en población colombiana. Acta Colombiana de Psicología, Bogotá, v. 9, n. 2, p. 127-140, dez. 2006. Disponível em $<\mathrm{http}$ :/www.scielo.org.co/scielo.php?script=sci_arttext\&pid=S0123$91552006000200012 \& \operatorname{lng}=$ en\&nrm=iso $>$. Acesso em 16 jan. 2016.

LOEWALD, H.W. Internalization, separation, mourning, and the superego. In: FRANKIEL, R. V. (Ed.). Essential papers on object loss. Nova York: NY University Press, 1994. p. 123-141. Publicado originalmente em 1962.

LONDOÑO A., N. H. et al. Validación del Cuestionario de Creencias Centrales de los Trastornos de la Personalidad (CCE-TP) en población colombiana. Avances en Psicología Latinoamericana, Bogotá, v. 25, n. 2, p. 138-162, dez. 2007. Disponível em $<$ http://www.scielo.org.co/scielo.php?script=sci_arttext\&pid=S1794$47242007000200010 \& \operatorname{lng}=\mathrm{en} \& \mathrm{nrm}=\mathrm{iso}>$. Acesso em 16 jan. 2016.

LONDOÑO PAREDES, D. E. Elucidación epistémica e histórica del trastorno de la personalidad límite o borderline. Revista Colombiana de Psiquiatría, Bogotá, v. 44, n. 3, p. 189-195, jul.-dez. 2015.

LÓPEZ, D.; CUEVAS, P.; GÓMES, A.; MENDOZA, J. Psicoterapia focalizada en la transferencia para el trastorno límite de la personalidad: Un estudio con pacientes femeninas. Salud Mental, Cidade do México, v. 27, n. 4, p. 44-54, ago. 2004. Disponível em $<$ http://www.redalyc.org/articulo.oa?id=58242706> Acesso em 21 jan. 2016. 
LUNBECK, E. Borderline histories: Psychoanalysis inside and out. Science in Context, Cambridge/Nova York, v. 19, n. 1, p 151-173, mar. 2016.

doi: $10.1017 / \mathrm{S} 0269889705000803$.

MANN, K. Behavioral addiction: New challenges for psychiatrists and psychotherapists? Nervenarzt, Berlim, v. 84, n. 5, p. 547, mai. 2013. doi: 10.1007/s00115-0123717-0. Original em alemão.

MARTINS, R. C. Psicodinâmica de usuários de drogas: Contribuições da avaliação psicológica. 2003. 147 f. Dissertação (Mestrado em Psicologia) - Faculdade de Filosofia, Ciências e Letras de Ribeirão Preto, Universidade de São Paulo, Ribeirão Preto, 2003. Disponível em <http://www.teses.usp.br/teses/disponiveis/59/59137/tde18082009-104632/>. Acesso em 23 de jan. 2016.

MATUSOW, H.; ROSENBLUM, A. The most critical unresolved issue associated with: Psychoanalytic theories of addiction: Can the talking cure tell us anything about substance use and misuse? Substance Use \& Misuse, Monticello, NY, v. 48, n. 3, p. 239247, fev. 2013. doi: 10.3109/10826084.2012.753548.

MAZER, A. K. Diagnóstico diferencial entre transtorno afetivo bipolar e transtorno de personalidade borderline fundamentado na história de estresse precoce e em avaliação psiconeuroendócrina. 2013. 147 f. Dissertação (Mestrado em Saúde Mental) - Faculdade de Medicina de Ribeirão Preto, Universidade de São Paulo, Ribeirão Preto, 2013. Disponível em <http://www.teses.usp.br/teses/disponiveis/17/17148/tde-20052014085440/>. Acesso em 26 de out. 2014.

MCDOUGALL, J. As múltiplas faces de Eros. São Paulo: Martins Fontes, 1997. . Teatros do Eu. Rio de Janeiro: Francisco Alves, 1992.

MEDEIROS, C.; AIELLO-VAISBERG, T. M. J. Acordes do sofrimento humano. Contextos Clínicos, São Leopoldo, v. 3, n. 2, p. 97-105, dez. 2010. Disponível em $<$ http://pepsic.bvsalud.org/scielo.php?script=sci_arttext\&pid=S1983$34822010000200003 \& \operatorname{lng}=$ pt\&nrm=iso $>$. Acesso em 18 jun. 2016.

MEZAN, R. Pesquisa teórica em psicanálise. Psicanálise e Universidade, São Paulo, v. 2, p. 51-76, 1994.

O que significa pesquisa em psicanálise? In: . A sombra de Don Juan e outros ensaios. São Paulo: Companhia das Letras, 1998. p. 85-118.

MIEL, C. La toxicomanie ou la quête impossible de l'objet. Psychotropes, Paris, v. 8, n. 1, jan. 2002 . 
MINERBO, M. Neurose e não-neurose. São Paulo: Casa do Psicólogo, 2009.

MORAES, P. H. P. de et al . Relationship between neuropsychological and clinical aspects and suicide attempts in euthymic bipolar patients. Psicologia: Reflexão e Crítica, Porto Alegre, v. 26, n. 1, p. 160-167, jan.-mar. 2013.

Disponível em $<$ http://www.scielo.br/scielo.php?script=sci_arttext\&pid=S0102$79722013000100017 \& \operatorname{lng}=$ en\&nrm=iso $>$. Acesso em 17 jan. 2016. http://dx.doi.org/10.1590/S0102-79722013000100017.

MORENO, M. M. A. Trauma precoce e ligações psíquicas, um estudo psicanalítico. 2014. Tese. 207 f. Tese (Doutorado em Psicologia Experimental) - Instituto de Psicologia, Universidade de São Paulo, São Paulo, 2014. Disponível em: $<$ http://www.teses.usp.br/teses/disponiveis/47/47132/tde-05032015-115420/>. Acesso em: 2016-01-24.

MOURA, A.; NIKOS, I. Estudos de caso, construção do caso e ensaio metapsicológico: Da clínica psicanalítica à pesquisa psicanalítica. Pulsional Revista de Psicanálise, São Paulo, n. 140-141, p. 69-76, 2000.

MOURÃO, M. M. G. Da possibilidade do habitar: O corpo como morada. Corporeidade e formas subjetivas contemporâneas. 2012. 116 f. Dissertação (Mestrado em Psicologia Social) - Instituto de Psicologia, Universidade de São Paulo, São Paulo, 2012. Disponível em < http://www.teses.usp.br/teses/disponiveis/47/47134/tde-19072012093856/>. Acesso em 23 de jan. 2016.

MUNDURUCA, G. de O. Contribuição para o estudo da constituição psíquica de mulheres alcoolistas. 2008. 204 f. Tese (Doutorado em Psicologia Escolar e do Desenvolvimento Humano) - Instituto de Psicologia, Universidade de São Paulo, São Paulo, 2008. Disponível em <http://www.teses.usp.br/teses/disponiveis/47/47131/tde15122008-164948/>. Acesso em 23 de jan. 2016.

MUÑOZ, P. D. Algunas elaboraciones psicoanalíticas en torno del uso del concepto de locura como distinto del concepto de psicosis. Anuario de Investigaciones, Buenos Aires, v. 16, p. 125-132, dez. 2016. Disponível em <http://www.scielo.org.ar/ scielo.php?script=sci_arttext\&pid=S1851-16862009000100050\&lng=es\&nrm=iso $>$. Acesso em 16 jan. 2016.

NAFFAH NETO, A. Falso Self e patologia borderline no pensamento de Winnicott: Antecedentes históricos e desenvolvimentos subsequentes. Natureza humana, São Paulo, v. 12, n. 2, p. 1-18, dez. 2010. 
NASCIMENTO, A. P. et al. Sobre o que se transporta: (Contra)Transferência(s). Análise Psicológica, Lisboa, v. 29, n. 3, p. 467-482, jul. 2011. Disponível em $<$ http://www.scielo.mec.pt/scielo.php?script=sci_arttext\&pid=S0870$82312011000300007 \& \operatorname{lng}=$ pt\&nrm=iso>. Acesso em 16 jan. 2016.

NEUBERN, M. S. Três obstáculos epistemológicos para o reconhecimento da subjetividade na psicologia clínica. Psicologia: Reflexão e Crítica, Brasília, v. 14, n. 1, p. 241-252, jan.-abr. 2001.

NUNES-COSTA, R. A.; LAMELA, D. J. P. do V.; GIL-COSTA, L. Teoria e eficácia da terapia comportamental dialética na bulimia nervosa e no transtorno da compulsão alimentar periódica. Jornal Brasileiro de Psiquiatria, Rio de Janeiro, v. 58, n. 2, p. 122-127, abr.-jun. 2009. Disponível em <http://www.scielo.br/scielo.php?script= sci_arttext\&pid=S0047-20852009000200010\&lng=en\&nrm=iso >. Acesso em 17 jan. 2016. http://dx.doi.org/10.1590/S0047-20852009000200010.

ORANGE, D. M. Emotional understanding: Studies in psychoanalytic epistemology. Nova York: Guilford Press, 1995.

OUTEIRAL, J. O adolescente borderline. Porto Alegre: Artes Médicas, 1993.

PAZ, R. Psicopatologia: Sus fundamentos dinamicos. Buenos Aires: Nueva Visión, 1976.

PEREIRA, D. R. Aspectos da compulsão à repetição na clínica psicanalítica: Resistências e toxicomania. 2013. 127 f. Dissertação (Mestrado em Psicologia Clínica) - Instituto de Psicologia, Universidade de São Paulo, São Paulo, 2013. Disponível em $<$ http://www.teses.usp.br/teses/disponiveis/47/47133/tde-09012014-095422/>. Acesso em 23 jan. 2016.

PEREIRA, M. E. C. A Introdução do conceito de "estados-limítrofes" em psicanálise: $\mathrm{O}$ artigo de A. Stern sobre "the borderline group of neuroses". Revista Latinoamericana de Psicopatologia Fundamental, São Paulo, v. 2, n. 2, p.153-158, jun. 1999.

PÉREZ, I. T.; DEL RÍO SÁNCHEZ, C.; MAS, M. B. MCMI-II borderline personality disorder in anorexia and bulimia nervosa. Psicothema, Oviedo, v. 20, n. 1, p. 138-143, jan.-mar. 2008.

PETERSEN, T.; FAVA, M.; ALPERT, J. E.; VORONO, S.; SANDERS, K. M.; MISCHOULON, D. Does psychiatry residency training reflect the "real world" of psychiatry practice? A survey of residency graduates. Academic Psychiatry, Washington, v. 31, n. 4, p. 281-289, jul.-ago. 2007. Disponível em 
$<$ http://www.ncbi.nlm.nih.gov/pubmed/17626190>. Acesso em 21 jan. 2016. DOI: 10.1176/appi.ap.31.4.281.

PIMENTEL, P. K. de A.; COELHO JUNIOR, N. Algumas considerações sobre o uso da empatia em casos e situações limite. Psicologia Clínica, Rio de Janeiro, v. 21, n. 2, p. 301-314, jul.-dez. 2009. Disponível em <http://www.scielo.br/scielo.php?script= sci_arttext\&pid=S0103-56652009000200004\&lng=en\&nrm=iso $>$. Acesso em 17 jan. 2016. http://dx.doi.org/10.1590/S0103-56652009000200004

PINEL, P. Traité médico-philosophique sur l'aliénation mentale. Paris: Les Empêcheurs de Penser en Ronds; Seuil, 2005.

POLITZER, G. Crítica aos fundamentos da psicologia: A psicologia e a psicanálise. Piracicaba: UNIMEP, 1998. Publicado originalmente em 1928.

PORTELA DE CARVALHO, M. T.; DE CAMARGO VIANA, T. Trauma and the negative narcissism in borderline cases. Psychologia. Avances de la Disciplina, Bogotá, v. 7, n. 2, p. 101-114, dez. 2013. Disponível em <http://www.scielo.org.co/scielo.php? script $=$ sci_arttext\&pid $=\mathrm{S} 1900-23862013000200008 \& \operatorname{lng}=\mathrm{en} \& \mathrm{nrm}=\mathrm{iso}>$. Acesso em 16 jan. 2016.

PORTOCARRERO, V. Arquivos da loucura: Juliano Moreira e a descontinuidade histórica da psiquiatria [online]. Rio de Janeiro: Fiocruz, 2002. (Loucura \& Civilização, v.4). Disponível em <http://static.scielo.org/scielobooks/p26q6/pdf/portocarrero9788575413883.pdf $>$. Acesso em 12 jan. 2016.

PRESS, C. M. Psychoanalysis, creativity, and hope: Forward edge strivings in the life and work of choreographer Paul Taylor. Journal of the American Academy of Psychoanalysis, Nova York, v. 33, n. 1, p. 119-136, Spring 2005.

QUAGLIATTO, H. de S. M.; SANTOS, R. G. Psicoterapia psicanalítica e acompanhamento terapêutico: Uma aliança de trabalho. Psicologia: Ciência e Profissão, Brasília, v. 24, n. 1, p. 74-81, mar. 2004. Disponível em <http://www.scielo.br/scielo.php?script= sci_arttext\&pid=S1414-98932004000100009\&lng=pt\&nrm=iso $>$. Acesso em 27 out. 2014. http://dx.doi.org/10.1590/S1414-98932004000100009.

QUEIROZ, F. C. A. Representação no campo do traumático: A enfermidade grave na infância e o impacto sobre o desenvolvimento. 2011. 130 f. Tese (Doutorado em Psicologia Escolar e do Desenvolvimento Humano) - Instituto de Psicologia, Universidade de São Paulo, São Paulo, 2011. Disponível em: <http://www.teses.usp.br/teses/ disponiveis/47/47131/tde-17042012-121637/>. Acesso em 23 de jan. 2016. 
RIOSECO S, Pedro et al. Prevalencia de trastornos psiquiátricos en adolescentes infractores de ley: Estudio caso-control. Revista Chilena de Neuro-Psiquiatría, Santiago, v. 47, n. 3, p. 190-200, jul.-set. 2009. Disponível em $<$ http://www.scielo.cl/ scielo.php?script $=$ sci_arttext\&pid=S0717-92272009000300003\&lng=es\&nrm=iso $>$. Acesso em 16 jan. 2016. http://dx.doi.org/10.4067/S0717-92272009000300003.

ROBERT, P. F. P. Da transferência negativa à destrutividade: Percursos da clínica psicanalítica. 2015. 201 f. Tese (Doutorado em Psicologia Clínica) - Instituto de Psicologia, Universidade de São Paulo, São Paulo, 2015. Disponível em: < http://www.teses.usp.br/teses/disponiveis/47/47133/tde-13072015-121208/>. Acesso em 23 de jan. 2016.

RODRIGUEZ MOYA, L.; FERNANDEZ BELINCHON, C. Psicoterapia cognitivo analítica y trastornos de la personalidad: Revisión. Acción Psicológica, Madrid, v. 10, n. 1, p. 65-74, jun. 2013 . Disponível em <http://scielo.isciii.es/scielo.php?script= sci_arttext\&pid=S1578-908X2013000100007\&lng=es\&nrm=iso $>$. Acesso em 17 jan. 2016. http://dx.doi.org/10.5944/ap.10.1.7034.

RODRIGUEZ SUTIL, C. et al . Reconsiderando la clasificación psicopatológica desde el punto de vista psicoanalítico-relacional: Lo histérico/ histriónico como modelo. Revista de la Asociación Española de Neuropsiquiatría, Madrid, v. 33, n. 120, p. 693-711, dez. 2013. Disponível em <http://scielo.isciii.es/scielo.php?script= sci_arttext\&pid=S0211-57352013000400003\&lng=es\&nrm=iso $>$. Acesso em 16 jan. 2016. http://dx.doi.org/10.4321/S0211-57352013000400003.

RONCOLATO, A. A. Psicodiagnóstico compreensivo de crianças com distúrbios de conduta: Aspectos psicodinâmicos. 2011. 123 f. Dissertação (Mestrado em Psicologia Clínica) - Instituto de Psicologia, Universidade de São Paulo, São Paulo, 2011. Disponível em: <http://www.teses.usp.br/teses/disponiveis/47/47133/tde-22072011-154721/>. Acesso em: 2016-01-23.

ROSA, B. de P.; SANTOS, M. A. dos. Comorbidade entre bulimia e transtorno de personalidade borderline: Implicações para o tratamento. Revista Latinoamericana de Psicopatologia Fundamental, São Paulo, v. 14, n. 2, p. 268-282, jun. 2011.

Disponível em $<$ http://www.scielo.br/scielo.php?script=sci_arttext\&pid=S1415$47142011000200005 \& \operatorname{lng}=$ en\&nrm=iso $>$. Acesso em 17 jan. 2016. http://dx.doi.org/10.1590/S1415-47142011000200005.

ROSENFELD, H. A. Os estados psicóticos. Rio de Janeiro: Zahar, 1968.

SADI, H. M. Análise dos comportamentos de terapeuta e cliente em um caso de transtorno de personalidade borderline. 2011. 120 f. Tese (Doutorado em Psicologia Clíni- 
ca) - Instituto de Psicologia, Universidade de São Paulo, São Paulo, 2011. Disponível em: < http://www.teses.usp.br/teses/disponiveis/47/47133/tde-04112011-115705/>. Acesso em 26 de out. 2014.

SAFRA, G. Acompanhamento terapêutico e clínica contemporânea. Santo André: Faculdade de Medicina do ABC, 2014. Comunicação oral.

Curando com histórias: A inclusão dos pais na consulta terapêutica das crianças. São Paulo: Sobornost, 2005.

SALOMONE, V. P. D. Contribuições de D. W. Winnicott para o estudo do distúrbio Borderline e suas implicações clínicas. 2009. 91 f. Dissertação (Mestrado em Psicologia Clínica) - Pontifícia Universidade Católica de São Paulo, São Paulo, 2009.

SANCHEZ QUINTERO, S.; VEGA, I. de la. Introducción al tratamiento basado en la mentalización para el trastorno límite de la personalidad. Acción Psicológica, Madrid, v. 10, n. 1, p. 21-32, jun. 2013 . Disponível em $<$ http://scielo.isciii.es/scielo.php?script $=$ sci_arttext\&pid=S1578-908X2013000100003\&lng=es\&nrm=iso $>$. Acesso em 17 jan. 2016. http://dx.doi.org/10.5944/ap.10.1.7030.

SANTOS, N. de O. et al. Psychogenic non-epileptic seizures and psychoanalytical treatment: Results. Revista da Associação Médica Brasileira, São Paulo, v. 60, n. 6, p. 577-584, dez. 2014. Disponível em

$<$ http://www.scielo.br/scielo.php?script=sci_arttext\&pid $=\mathrm{S} 0104-42302014000600577 \& \operatorname{lng}=\mathrm{en} \& \mathrm{nrm}=\mathrm{iso}>$. Acesso em 17 jan. 2016 . http://dx.doi.org/10.1590/1806-9282.60.06.018.

SANTOS, A. B. dos R.; BESSET, V. L. A perversão, o desejo e o gozo: Articulações possíveis. Estudos de Psicologia (Campinas), Campinas, v. 30, n. 3, p. 405-413, set. 2013. Disponível em $<$ http://www.scielo.br/scielo.php?script=sci_arttext\&pid=S0103166X2013000300010\&lng=pt\&nrm=iso>. Acesso em 27 out. 2014. http://dx.doi.org/10.1590/S0103-166X2013000300010.

SANTOS, S. R. et al. Perfil dos fumantes que procuram um centro de cessação de tabagismo. Jornal Brasileiro de Pneumologia, São Paulo, v. 34, n. 9, p. 695-701, set. 2008. Disponível em $<$ http://www.scielo.br/scielo.php?script=sci_arttext\&pid=S180637132008000900010\&lng=pt\&nrm=iso >. Acesso em 27 out. 2014. http://dx.doi.org/10.1590/S1806-37132008000900010.

SAVIETTO, B. B. Drogadicção na juventude contemporânea: A "intoxicação" pelo outro. 2010. 132 f. Tese (Doutorado em Teoria Psicanalítica) - Instituto de Psicologia, Universidade Federal do Rio de Janeiro, Rio de Janeiro, 2010. 
SCHÜßLER, G. How addiction develops and what are the consequences: A psychodynamic approach. Addiction and psychodynamic aspects. Psychiatria Danubina, Zagreb, v. 26, n. 4, p. 368-371, dez. 2014. Disponível em <http://www.hdbp.org/ psychiatria_danubina/pdf/dnb_vol26_no4/dnb_vol26_no4_368.pdf $>$. Acesso em 26 jan. 2016.

SIMMEL, E. From psychoanalytic treatment in a sanatorium. In: YALISOVE, D. L. (Ed.). Essential papers on addiction. Nova York: NY University Press, 1997. p. 69-71. Publicado originalmente em 1933.

SILVA, J. F. R. da; YAZIGI, L.; FIORE, M. L. de M. Psicanálise e universidade: A interface possível por meio da pesquisa psicanalítica clínica. Alice quebra-vidros. Revista Brasileira de Psiquiatria, São Paulo, v. 30, n. 2, p. 152-155, jun. 2008. Disponível em $<$ http://www.scielo.br/scielo.php?script=sci_arttext\&pid=S1516$44462008000200013 \& \operatorname{lng}=$ pt\&nrm=iso $>$. Acesso em 27 out. 2014. Epub 28-Abr-2008. http://dx.doi.org/10.1590/S1516-44462008005000011.

SOPHIA, E. C. Amor patológico: Aspectos clínicos e de personalidade. 2008. Dissertação (Mestrado em Psiquiatria) - Faculdade de Medicina, Universidade de São Paulo, São Paulo, 2008. 130 f. Disponível em: <http://www.teses.usp.br/teses/disponiveis/5/ 5142/tde-11022009-162136/>. Acesso em 23 de jan. 2016.

STERN, A. Psychoanalytic investigation of and theraphy in bordeline group of neuroses. In: STONE, M. H. (Ed.). Essential papers on borderline disorders: One hundred years at the border. Nova York: NY Univerity Press, 1986. p. 54-73. Publicado originalmente em 1938.

STONE, M. H. The borderline syndromes. New York: McGraw-Hill, 1980. The fate of borderline patients. New York: Guilford, 1990.

SZTULMAN, H. Entre addiction et ordalie, les toxicomanes. Adolescence, Toulouse, v.15, n. 2, p. 57-65, abr.-mai. 1997.

TAMAYO, J. M. et al . Definición e impacto de las depresiones resistentes/refractarias al tratamiento. Salud Mental, México, v. 34, n. 3, p. 247-255, jun. 2011 . Disponível em <http://www.scielo.org.mx/scielo.php?script=sci_arttext\&pid=S0185$33252011000300008 \& \operatorname{lng}=$ es\&nrm=iso $>$. Acesso em 17 jan. 2016.

TANESI, P. H. V. et al. Adesão ao tratamento clínico no transtorno de personalidade borderline. Estudos de Psicologia (Natal), Natal, v. 12, n. 1, p. 71-78, abr. 2007. 
Disponível em $<$ http://www.scielo.br/scielo.php?script=sci_arttext\&pid=S1413294X2007000100009\&lng=pt\&nrm=iso>. Acesso em 27 out. 2014. http://dx.doi.org/10.1590/S1413-294X2007000100009.

TARDIVO, L. S. L. P. C.; VAISBERG, T. A. Natureza e esportes ou violência e drogas? A juventude no imaginário de jovens indígenas aculturados. Revista de Psicologia, São Paulo, v. 2, n. 2/3, p. 26-37, 2002.

TARDIVO, L. S. L. P. C. O adolescente e sofrimento emocional nos dias de hoje: Reflexões psicológicas: Encontros e viagens. 2004. 213 f. Tese (Livre-docência em Psicologia) - Instituto de Psicologia, Universidade de São Paulo, São Paulo, 2004.

TARDIVO, L. S. L. P. C.; GIL, C. A. APOIAR: Novas propostas em psicologia clínica. São Paulo: Sarvier, 2008.

TARDIVO, L. S. L. P. C.; GIL, C. A.; VAGOSTELLO, L.; RABELLO, I. Evaluación proyectiva en adultos mayores: Estudio de la precisión y validez del SAT (Senior Aperception Test). In: TRIMBOLI, A. et al. (Org.). Trauma, história y subjetividade. Buenos Aires: Associación Argentina de Salud Mental, 2010. p. 97-99.

TRAMANTANO, G.; JAVIER, R.A.; COLON, M. Discriminating among subgroups of borderline personality disorder: An assessment of object representations. American Journal of Psychoanalysis, Nova York, v. 63, n. 2, p. 149-175, jun. 2003.

TURATO, E. R. Tratado da metodologia da pesquisa clínico-qualitativa: Construção teórico-epistemológica, discussão comparada e aplicação nas áreas da saúde e humanas. Rio de Janeiro: Vozes, 2000.

VAILLANT, G. Conversation with George Vaillant. Addiction, London v. 100, n. 3, p. 274-280, mar. 2005. doi:10.1111/j.1360-0443.2005.00999.x

VALENTINE, K.; FRASER, S. Trauma, damage and pleasure: Rethinking problematic drug use. International Journal of Drug Policy, Liverpool, v. 19, n. 5, p. 410-416, out. 2008.

VIDAL, M.; LOWENKRON, T. Ensino da psicoterapia no atendimento psiquiátrico dos pacientes com transtorno de personalidade borderline. Psicologia: Teoria e Pesquisa, Brasília, v. 26, n. 4, p. 725-728, dez. 2010.

Disponível em $<$ http://www.scielo.br/scielo.php?script=sci_arttext\&pid=S0102$37722010000400016 \& \operatorname{lng}=$ pt\&nrm=iso $>$. Acesso em 27 out. 2014. http://dx.doi.org/10.1590/S0102-37722010000400016. 
VIDAL, P. E. V. A máquina do psiquismo. Estudos de Psicologia (Natal), Natal, v. 13, n. 3, p. 267-273, dez. 2008. Disponível em <http://www.scielo.br/scielo.php?script $=$ sci_arttext\&pid=S1413-294X2008000300009\&lng=pt\&nrm=iso $>$. Acesso em 27 out. 2014. http://dx.doi.org/10.1590/S1413-294X2008000300009.

VILLA, F. Mal-estar na civilização e desastre totalitário. Ágora (Rio de Janeiro), Rio de Janeiro, v. 15, n. especial, p. 493-512, dez. 2012. Disponível em <http://www.scielo.br/ scielo.php?script $=$ sci_arttext\&pid=S1516-14982012000300010\&lng=pt\&nrm=iso $>$. Acesso em 27 out. 2014. http://dx.doi.org/10.1590/S1516-14982012000300010.

WINNICOTT, D. W. A capacidade para estar só. In: O ambiente e os processos de maturação. Porto Alegre: Artes Médicas, 1990. p. 31-37. Publicado originalmente em 1958.

A observação de bebês em uma situação estabelecida. In: Textos selecionados: Da pediatria à psicanálise. Rio de Janeiro: Francisco Alves, 1993. Publicado originalmente em 1941.

. Classificação: Existe uma contribuição psicanalítica à classificação psiquiátrica? In: _. O ambiente e os processos de maturação. Porto Alegre: Artes Médicas, 1983. Publicado originalmente em 1965.

Consultas terapêuticas em psiquiatria infantil. Rio de Janeiro: Imago, 1984. Publicado originalmente em 1971b.

. O brincar e a realidade. Rio de Janeiro: Imago, 1975. Publicado originalmente em 1971.

. O medo do colapso. In: Explorações psicanalíticas. Porto Alegre: Artes Médicas, 1994. p. 70-76. Publicado originalmente em 1963.

O uso de um objeto e relacionamento através de identificações. In: O brincar e a realidade. Rio de Janeiro: Imago, 1975. p. 121-131. Publicado originalmente em 1971a.

Privação e delinquência. São Paulo: Martins Fontes, 2002. Publicado originalmente em 1958.

ZASLAVSKY, J.; SANTOS, M. J. P. dos. Contratransferência em psicoterapia e psiquiatria hoje. Revista de Psiquiatria do Rio Grande do Sul, Porto Alegre, v. 27, n. 3, p. 293-301, dez. 2005. Disponível em <http://www.scielo.br/scielo.php?script 
$=$ sci_arttext\&pid=S0101-81082005000300008\&lng=pt\&nrm=iso $>$. Acesso em 27 out. 2014. http://dx.doi.org/10.1590/S0101-81082005000300008. 